\title{
Shade trees in cacao agroforestry systems: influence on roots and net primary production
}

\author{
Dissertation \\ zur Erlangung des mathematisch-naturwissenschaftlichen Doktorgrades \\ „Doctor rerum naturalium“ \\ der Georg-August-Universität Göttingen
}

im Promotionsprogramm Biologie

der Georg-August University School of Science (GAUSS)

vorgelegt von

Yasmin Joana Monna Abou Rajab

aus Filderstadt

Göttingen, 2016 



\section{Betreuungsausschuss}

Prof. Dr. Christoph Leuschner, Abteilung Pflanzenökologie und Ökosystemforschung, Universität Göttingen

Prof. Dr. Hermann Behling, Abteilung Palynologie und Klimadynamik, Universität Göttingen

Dr. Dietrich Hertel, Abteilung Pflanzenökologie und Ökosystemforschung, Universität Göttingen (Anleiter)

\section{Mitglieder der Prüfungskommission}

Referent: Prof. Dr. Christoph Leuschner, Abteilung Pflanzenökologie und Ökosystemforschung, Universität Göttingen

Korreferent: Prof. Dr. Hermann Behling, Abteilung Palynologie und Klimadynamik, Universität Göttingen

\section{Weitere Mitglieder der Prüfungskommission}

Prof. Dr. Dirk Hölscher, Abteilung Waldbau und Waldökologie der Tropen, Universität Göttingen

Prof. Dr. Erwin Bergmeier, Abteilung Vegetationsanalyse und Phytodiversität, Universität Göttingen

Prof. Dr. Teja Tscharntke, Abteilung Agrarökologie, Universität Göttingen

Prof. Dr. Holger Kreft, Free Floater Nachwuchsgruppe- Biodiversität, Makroökologie und Biogeographie, Universität Göttingen 



\title{
Am Ende des Regenbogens
}

by Norbert Esser

\author{
Ganz weit draußen \\ am Ende des Regenbogens \\ werde ich auf Dich warten und \\ wenn Du dann endlich kommst, \\ werde ich sitzen bleiben \\ mit verschränkten Armen \\ über den Knien \\ damit du nicht \\ zu früh erfährst, \\ mit welcher Sehnsucht \\ ich Dich erwartet habe.
}

For Constanze, Constantin and Ruth Klett 



\section{Table of contents}

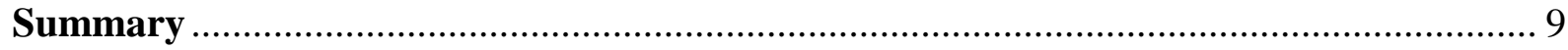

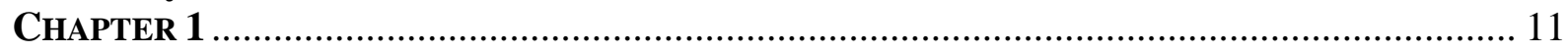

General Introduction

1.1 Deforestation and biodiversity losses in the tropics through land use change ............... 12

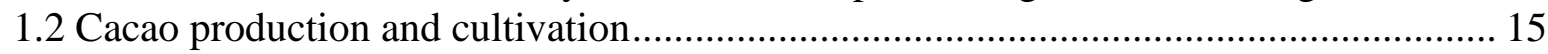

1.3 Effects of shade tree removal and intensification in cacao agro-forestry systems........ 16

1.4 Tree growth as influenced by hydraulic architecture of roots, stems, and twigs ........... 18

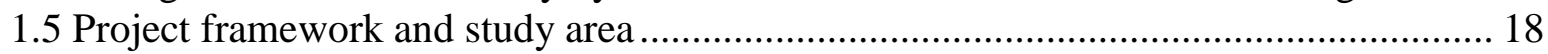

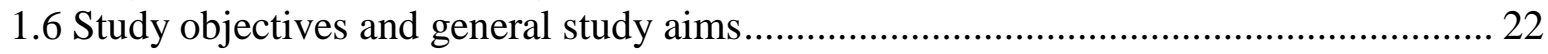

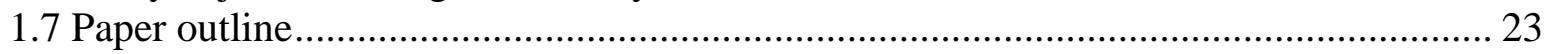

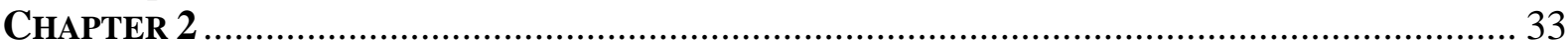

Cacao cultivation under diverse shade tree cover allows high carbon storage and sequestration without yield losses

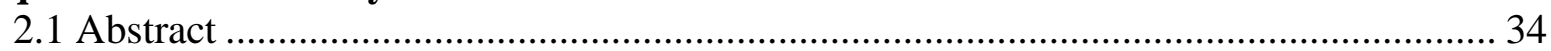

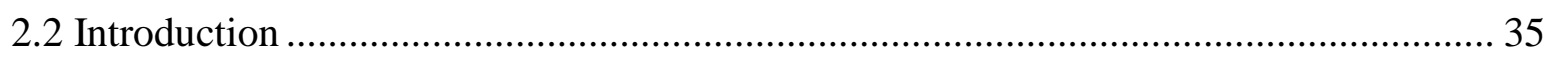

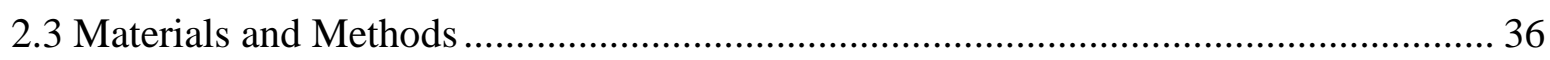

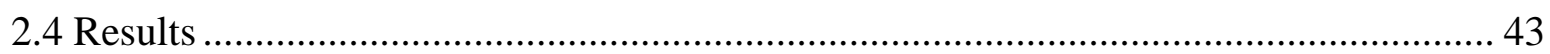

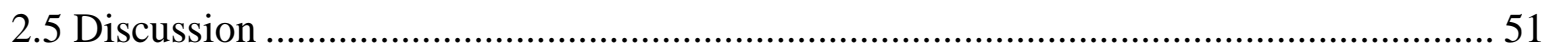

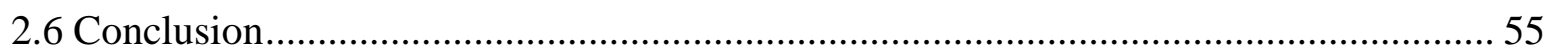

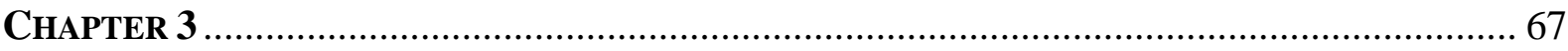

Abundance and diversity of shade trees in cacao agroforests (Indonesia) alters vertical rooting patterns and fine root dynamics

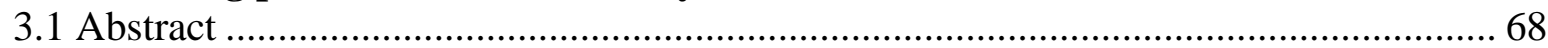

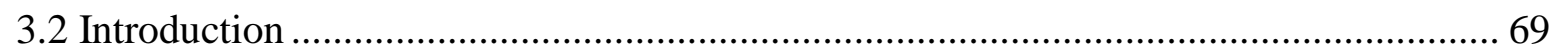

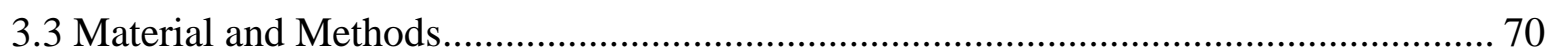

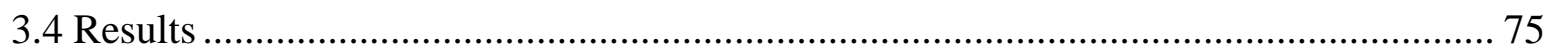

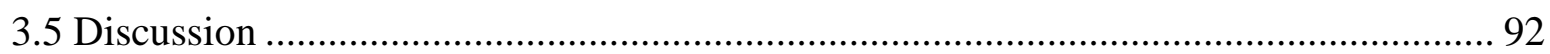

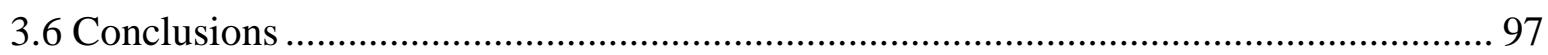

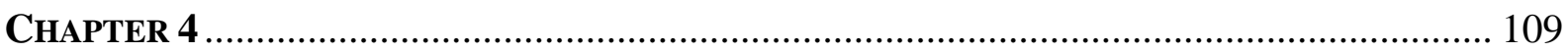

Patterns in hydraulic architecture from roots to branches in six tropical tree species from cacao agroforestry and their relation to wood density and stem growth

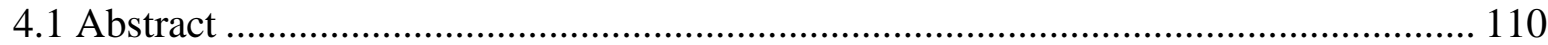

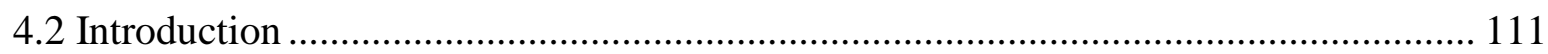

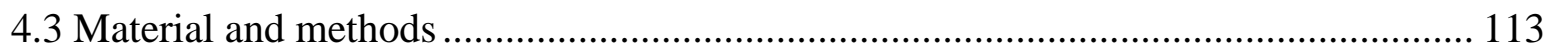

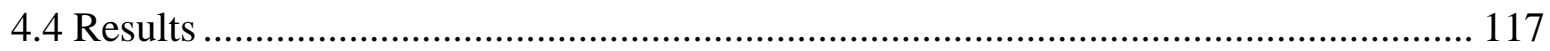

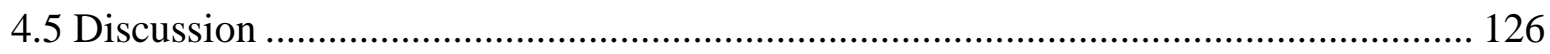

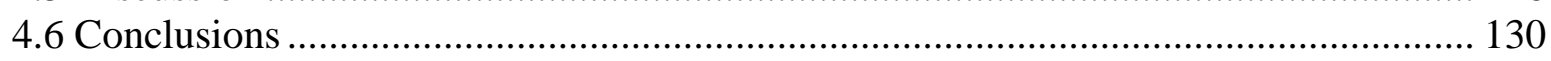

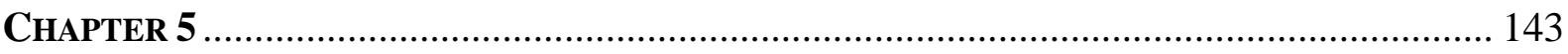

Synthesis

5.1 Effects of shade trees on stand structure, biomass and carbon stocks ....................... 144

5.2 Effects of shade trees on productivity and carbon sequestration ................................ 145

5.3 Overall conclusions and resulting recommendation for cacao farmers ...................... 148

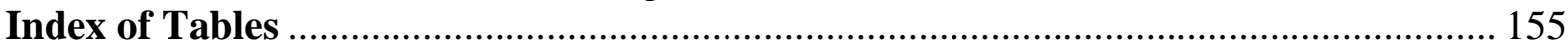

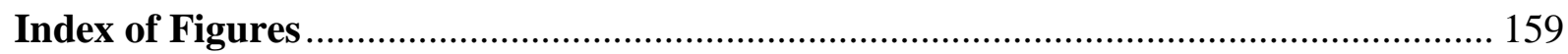

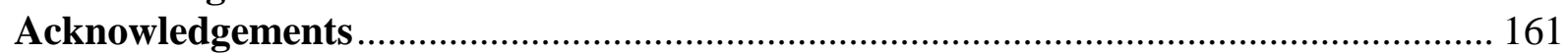





\section{Summary}

Huge areas of natural forests are rapidly cleared worldwide to make way for agricultural cultivation systems. This has a substantial impact on the functioning of ecosystems, as well as on carbon cycling and hence effects global climate change. Currently, Indonesia has one of the highest deforestation rates worldwide and on the island of Sulawesi, where this study was carried out, substantial tracts of primary forest are being cleared in order to predominantly cultivate cacao (Theobroma cacao L.), which made Sulawesi the biggest producer of cacao within Indonesia. Cacao is an understory rainforest species and was traditionally planted beneath thinned primary forest, but naturally occurring shade trees are increasingly being replaced by planted shade trees, such as fast growing nitrogen-fixing or other commercially valuable species. Nowadays, shade trees are often completely or partly removed as the cacao tree matures, because farmers fear that above- and belowground competition for light, water and nutrients will diminish bean yield. Not only do diverse agroforestry systems harbor higher biodiversity and enhance carbon sequestration and soil fertility, they also provide microclimatic benefits such as increased humidity and buffer temperature extremes, thus also improving drought resistance. However, not much is known about the effects these intensifications have on already existing cultivation systems.

The present thesis aims to compare cacao agroforests with different shade intensities, focusing on above- and belowground biomass, carbon stocks and net primary production, as well as on vertical root distribution, fine root dynamics and the hydraulic-anatomical architecture of cacao and shade trees. Shade tree cover increased from: 1) non-shaded cacao monoculture ('Cacao-mono') to 2) planted single-shade by the nitrogen fixing Gliricidia sepium (Jacq.) Kunth ('Cacao-Gliricidia') to 3) a multi-species shade tree layer ('Cacao-multi'). The general hypotheses we wanted to verify were that i) above- and belowground biomass and NPP, as well as the related $\mathrm{C}$ stock and $\mathrm{C}$ sequestration increase with increasing shade tree cover, that ii) cacao bean yield is negatively affected by an increasing shade tree cover, that iii) standing fine root biomass, production and turnover increase with increasing shade tree cover, that iv) there is vertical root segregation between cacao and shade trees and that $v$ ) aboveground productivity is positively related to vessel size and hydraulic conductivity.

In order to test these general hypotheses, this dissertation is subdivided into three studies. In the first study (Chapter 2), the three cultivation systems were compared with respect to aboveand belowground biomass and the corresponding carbon (C) stocks, as well as above- and belowground net primary production (NPP) and the associated $\mathrm{C}$ sequestration. As hypothesized, total above- and belowground biomass and NPP increased from 23 to $124 \mathrm{Mg} \mathrm{ha}^{-1}$ and 20 to $38 \mathrm{Mg} \mathrm{ha}^{-1} \mathrm{yr}^{-1}$, respectively, as well as the corresponding $\mathrm{C}$ stocks and $\mathrm{C}$ sequestration increased significantly (from 11 to $57 \mathrm{Mg} \mathrm{C}^{-1}$ and 9 to $18 \mathrm{Mg} \mathrm{C}^{-1} \mathrm{yr}^{-1}$, respectively) with increasing shade tree abundance and diversity. In contrast to the commonly held assumption, however, we did not detect a significant reduction in cacao bean production, although cocoa bean yield per individual tree slightly decreased, which was, however, not statistically significant. 
The second study (Chapter 3) addressed the influence of shade trees on vertical rooting patterns and fine root dynamics of cacao and shade trees. Biomass of fine, large and coarse roots increased with shade tree diversity and abundance. The highest standing fine root biomass values in the Cacao-mono and the Cacao-Gliricidia sites were located in the upper $20 \mathrm{~cm}$ and decreased with increasing soil depth, although Gliricidia-shaded plots showed a significantly higher fine root biomass in deeper soil layers compared to the Cacao-mono sites. The results of the deuterium stable isotope analysis revealed that cacao trees obtained water predominantly between 40 and $60 \mathrm{~cm}$ soil depth, while Gliricidia primarily took up water from deeper soil depths indicating vertical root distribution. In the Cacao-multi stands, the highest standing fine root biomass was located in the subsoil. In the Cacao-multi system, we have a clear indication that cacao and shade trees use the same depth interval for soil water uptake indicating a displacement effect as cacao roots were found in deeper soil layers. Contrasting to what was expected, no significant influence of shade trees on total fine root productivity could be proven. Annual production of cacao fine roots in the total soil profile was highest in the Cacao-mono plots $\left(167 \mathrm{~g} \mathrm{~m}^{-2} \mathrm{yr}^{-1}\right)$ and decreased slightly with increasing shade tree abundance and diversity (133 and $113 \mathrm{~g} \mathrm{~m}^{-2} \mathrm{yr}^{-1}$ in Cacao-Gliricidia and Cacao-multi, respectively). Shade tree species in both the Cacao-Gliricidia $\left(56 \mathrm{~g} \mathrm{~m}^{-2} \mathrm{yr}^{-1}\right)$ and the Cacao-multi plots $\left(40 \mathrm{~g} \mathrm{~m}^{-2} \mathrm{yr}^{-1}\right)$ had a significantly lower annual fine root production as compared to cacao.

In the third study (Chapter 4), the interrelationship between sapwood area and specific hydraulic conductivity of root, stem and branch xylem tissue with wood anatomical traits along the water flow path across six common cacao agroforestry tree species with different biogeographical origins (perhumid vs. drought-tolerant) were examined. Drought-adapted species showed divergent patterns of hydraulic conductivity, vessel density and relative vessel lumen area between root, stem and branch wood compared to perhumid forest species. Wood density showed no relationship to specific conductivity. In general, aboveground growth performance was better predicted by specific hydraulic conductivity than by foliar traits and wood density.

Overall, the results show that there is vertical root segregation between cacao and Gliricidia shade trees, but there seems to be a displacement effect of cacao roots to deeper soil layers when growing under a diverse shade tree layer. However, elevated specific root area and length and associated thinner cacao fine roots in the Cacao-multi stands may indeed compensate for the decrease in fine root biomass. Although shade trees may compete with the cacao trees for resources, there are several positive ecosystem services provided by shade trees which are likely to compensate for possible negative effects. Furthermore, additional income from carbon payments and from shade tree products as well as lower labor and input costs makes cacao production less susceptible to highly fluctuating prices. The present study proved that smallholder agroecosystems with diverse shade tree cover offer the opportunity to combine high yield, high biodiversity, and high carbon sequestration and thus may help to reduce tropical deforestation and mitigate global climate change. 


\section{CHAPTER 1}

General introduction 


\subsection{Deforestation and biodiversity losses in the tropics through land use change}

Forest loss and shrinking carbon sinks are one of the major contributors to increasing atmospheric carbon dioxide $\left(\mathrm{CO}_{2}\right)$ concentration and subsequent global climate change (e.g. Houghton et al. 2000, DeFries et al. 2002, Achard et al. 2002, DeFries et al. 2007, Miettinen et al. 2011). Deforestation ranks as the second largest anthropogenic source of $\mathrm{CO}_{2}$ to the atmosphere - after fossil fuel combustion - and accounts for 6-17\% of global anthropogenic $\mathrm{CO}_{2}$ emissions to the atmosphere (Van der Werf et al. 2009). From the year 2000-2012 a loss of 2.3 million $\mathrm{km}^{2}$ (mildly counteracted by a gain of 0.8 million $\mathrm{km}^{2}$ ) of global forests was reported by Hansen et al. (2013). The most threatened parts of the world are the tropical rainforest ecozones in Latin America, Africa, and Southeast Asia (Saatchi et al. 2011, Hansen et al. 2013). Out of these regions, Southeast Asia has one of the highest deforestation rates (Achard et al. 2002, Hansen and DeFries, 2004, Margono et al. 2012). At the national level, Brazil and Indonesia possess $35 \%$ of the total carbon stored in tropical forests, but produce also the largest emissions due to forest destruction (Baccini et al. 2012). Indonesia, where the present study took place, produced the second highest carbon emissions of $105 \mathrm{Tg} \mathrm{C} \mathrm{yr}^{-1}$ between 2000 and 2005 (Harris et al. 2012) and had a total forest cover loss of 15.8 Mha between 2000 and 2012 (Hansen et al. 2013, Margono et al. 2014), which has made Indonesia the third largest global emitter of $\mathrm{CO}_{2}$ to date (Margono et al. 2014, Lewis et al. 2015). The areas in Indonesia, where deforestation is proceeding most rapidly are the islands Sumatra and Kalimantan as well as Sulawesi (Fig. 1.1).

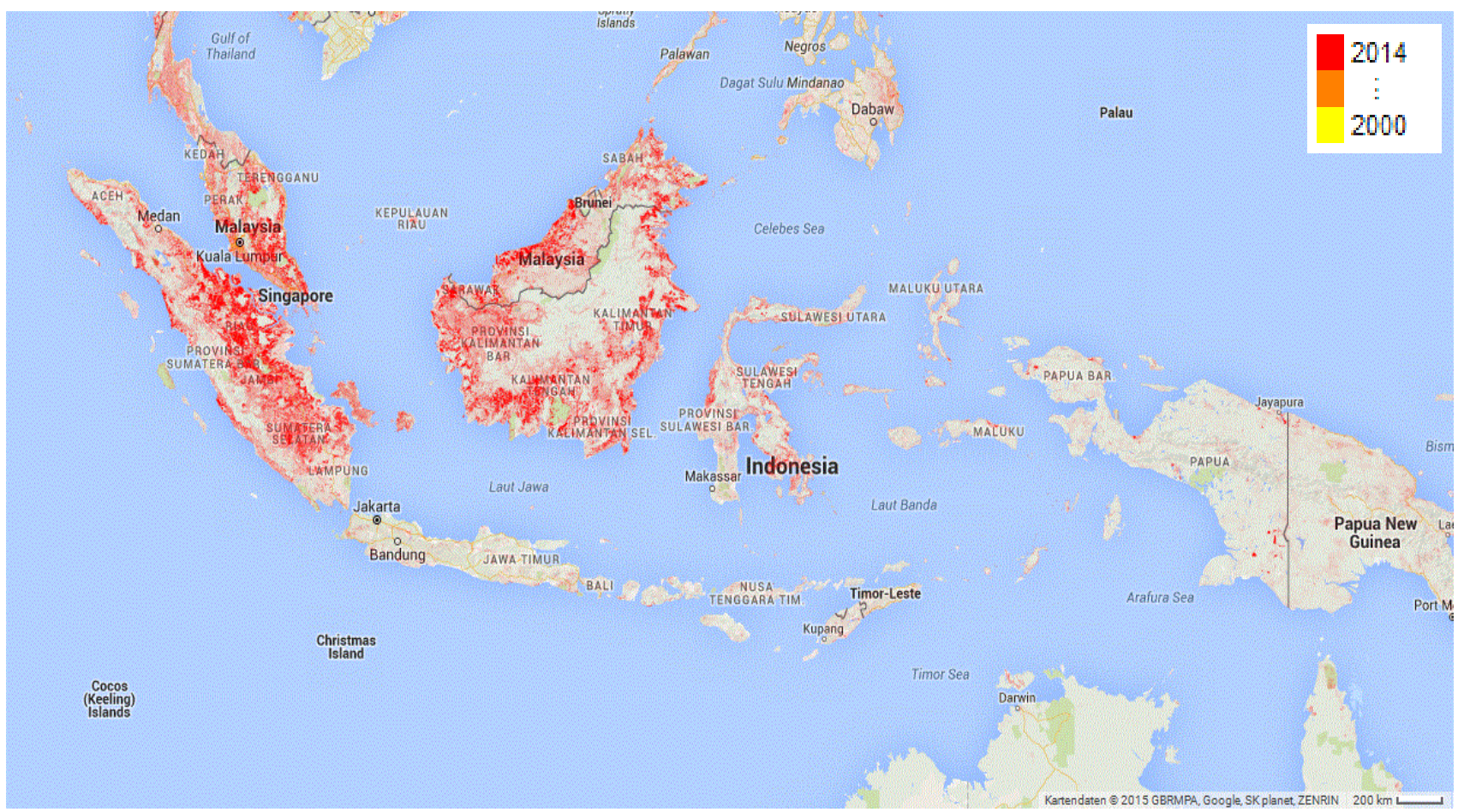

Figure 1.1: Forest cover loss in Indonesia from 2000-2014 (Source: Hansen/UMD/Google/USGS/NASA, Data available online from: http://earthenginepartners.appspot.com/science-2013-global-forest). 
Tropical forests provide many ecosystem services including the provision of renewable materials and energy, maintenance of biodiversity richness, protection of soil and water resources, as well as carbon and regulation of the global climate system (Foley et al. 2005, Kunert and Cárdenas 2015). Mostly, the deforested areas are converted into agricultural cultivation systems (e.g. Achard et al. 2002, Margono et al. 2012, Margono et al. 2014, Wilcove et al. 2013), which brings a huge loss of biodiversity in these regions with it and affects the delivery of important ecosystem services. Tropical ecosystems have exceptionally high species richness and are home to some of the highest concentrations of endemic species on earth (e.g. Myers and Mittermeier 2000, Sodhi et al. 2004). Four of the 25 biodiversity hotpots worldwide described by Myers and Mittermeier (2000) are located in SE Asia. The island of Sulawesi, where the investigations were carried out, is part of one such hotspot, the Wallacea. Its unique geological history, together with its stable tropical climate and numerous insular biotas, enabled the Wallacea to evolve highly endemic biotas (Sodhi et al. 2004). But here, huge areas of formally tropical rainforest are cleared for agricultural areas (Fig. 1.2 A). Mostly cacao is cultivated instead of formerly forested areas, which made Sulawesi the biggest producer of cacao within Indonesia comprising about $65 \%$ of Indonesia's cacao production (Clough et al. 2009, Leuschner et al. 2013).

The Lore Lindu National Park (LLNP) is one of the last remaining large, contiguous remnants of intact forest in Sulawesi with an area of about $2180 \mathrm{~km}^{2}$ (Culmsee et al. 2010 and Fig. 1.2 B), but increasing forest conversion into cacao cultivations, mostly monocultures, presents a major threat to primary forest in this region. In addition to tropical deforestation and forest conversion, further pressure on biological diversity is compounded through intensification of existing agricultural systems by increases in inputs and landscape homogenization through shade tree removal (Benton et al. 2003). Owing to exceptionally high biodiversity in SE Asian forest ecosystems and their immense amount of carbon stored, deforestation in this region has the potential to cause serious global consequences on climate and biodiversity (Miettinen et al. 2011). There is an ongoing debate whether land should be distinctly designated 'for nature' and 'for production' which in effect creates a segregation of land (land sparing) through agricultural intensification (high input-high yield), or whether a more integrated approach to land use should be adopted i.e. following wildlife-friendly farming (low-input-low yield) (Steffan-Dewenter et al. 2007, Wade et al. 2010, Tscharntke et al. 2012, Gilroy et al. 2014). 


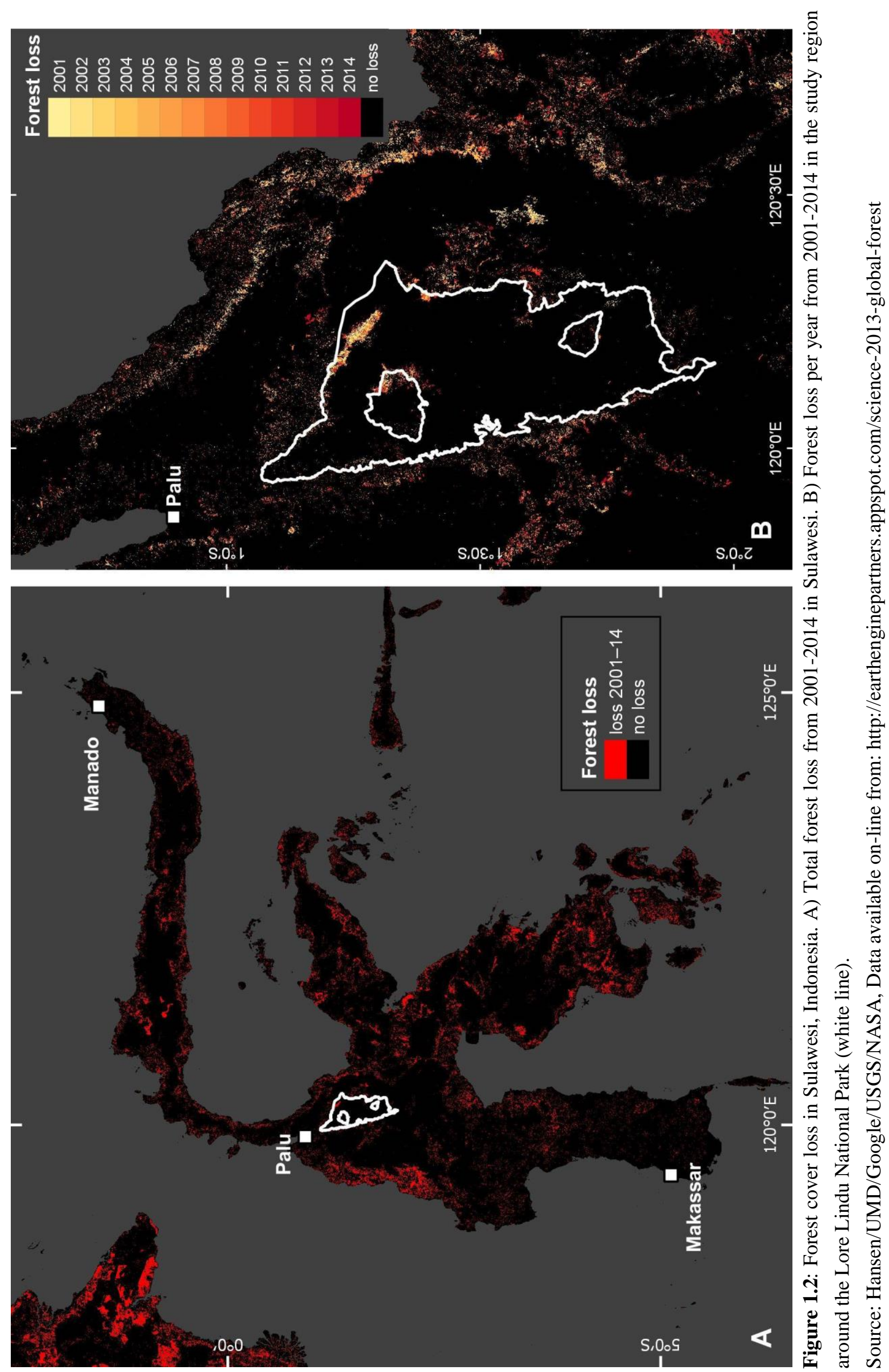




\subsection{Cacao production and cultivation}

Cacao (Theobroma cacao L., Malvaceae) is native to tropical South America and more precisely to the upper Amazon region (Motamayor et al. 2002). Although the Aztecs are known to have prepared a beverage made with a mixture of fermented and ground cacao seeds, maize and Capsicum peppers the chocolate that we are familiar with is an European invention (Clement et al. 2010). Reports of Mayan cultivation of cacao date back 1500 years (Motamayor et al. 2002), but other authors believe that cacao was domesticated in Mesoamerica as far back as 3000 years ago. The earliest known evidence for cacao use dates between 1900-1500 BC. Traditionally, two main genetic cacao groups have been defined depending on geographical location, genetic origin and morphological characters: 'Criollo' and 'Forastero', and later a third, 'Trinitario', was added which consists of 'Criollo' $\mathrm{x}$ Forastero' hybrids (Cheesman 1944). Most cacao varieties belong to these three groups (de Almeida and Valle 2007).

By 1560, cacao had been introduced to Indonesia by Spaniards coming from Venezuela (Susilo et al. 2011). It was first brought to northern Sulawesi (Minahassa), where cacao was only produced and consumed locally. Commercial cacao cultivation in Indonesia started much later in the early 1900s, after an outbreak of leaf rust disease in Arabica coffee which led farmers to switch to cacao (Susilo et al. 2011). As recently as 1980, cacao was introduced to the Lore Lindu area in Central Sulawesi (Weber et al. 2007), where this study took place. Across Indonesia and especially in Sulawesi, the 1980s and 1990s saw approximately 50\% of the cacao area emerging in formerly forested areas (Rice and Greenberg 2000). Sulawesi has continued to show a rapid expansion of cacao production in recent years, as well as a high rate of forest cover change of $-1.1 \% \mathrm{yr}^{-1}$ between 2000 and 2010 (Miettinen et al. 2011, see also Fig. 1.2).

Meanwhile, cacao has become one of the most important perennial cash crops worldwide. In 2013, world cacao bean production increased to about 5.0 million tons (FAO Statistical Databases: http://faostat.fao.org) with a steadily increasing demand of chocolate (Rice and Greenberg 2000, Bisseleua et al. 2009). In 2013, Indonesia ranked third among the highest producing countries worldwide, following Côte d'Ivoire and Ghana, with a total production of almost $780 \mathrm{Mt}$ (FAO Statistical Databases: http://faostat.fao.org).

Cacao is a crop of the humid lowland tropics cultivated largely by small-scale producers. Under natural conditions, the cauliflorous tree can reach 20 to $25 \mathrm{~m}$ in height (Lachenaud et al. 1997), whereas under cultivation it varies from 3 to $5 \mathrm{~m}$. Most varieties of Theobroma cacao are self-incompatible (Groeneveld et al. 2010) and thus strictly enthomophilous (Frimpong et al. 2011). The flowers are predominantly pollinated by tiny midges no larger than 2-3 mm (Young 1982) and belong mainly to the species Forcipomyia sp. (Diptera: Ceratopogonidae) (Dias et al. 1997). Flowers are produced continuously and for each flower, the sepals begin to dehisce in late afternoon and are fully open early the next morning, a period in which the anthers liberate pollen and the stigma is receptive (Aneja et al. 1999). 
Non-pollinated flowers abscise after 24-36 hours after anthesis without undergoing any visible signs of senescence (Aneja et al. 1999). The percentage of flowers setting pods is low, ranging from $0.5-5 \%$ (De Almeida and Valle 2007). The cacao pods itself require 6-7 months to mature (Moser et al. 2010). Traditionally, farmers harvest ripe cacao pods every two weeks, but pests and diseases cause huge losses in cacao yield worldwide (Bowers et al. 2001). The Black Pod disease e.g. is responsible for the most widespread destruction of cacao. It can be caused by several species of Phytophthora and can be found all over the world (Bowers et al. 2001). The cocoa pod borer Conopomorpha cramerella Snellen (Lepidoptera: Gracillariidae) is the major cacao pest in SE Asia and has caused crop losses of up to $50 \%$ (Day 1989). However, a multitude of other pests and diseases incur yield losses, but on a smaller scale.

As cacao is an understory rainforest species, it was traditionally planted beneath thinned primary or old secondary forest (Rice and Greenberg 2000). But progressively, the natural shade trees are being replaced by planted shade trees. Often, fast growing and nitrogen-fixing shade tree species like Gliricidia spp. or Erythrina spp., or trees that provide additional fruits, timber, or other commercially valuable goods are used. In Central Sulawesi, Gliricidia sepium (Jacq.) Kunth is the most commonly planted shade tree (Schwendenmann et al. 2010). Due to the need of shade of young cacao trees, cacao is cultivated on farms with an initially canopy of shade trees, but as the cacao matures shade trees are often partly or completely removed (e.g. Rice and Greenberg 2000, Siebert 2002, Belsky and Siebert 2003, Steffan-Dewenter et al. 2007, Bisseleua et al. 2009, Tscharntke et al. 2011). The current practice adopted by farmers is to remove shade trees, to increase yield, fearing that above- and belowground competition between cacao and shade trees for light, water and nutrients decreases production. However, this carries a huge loss of biodiversity both for flora and fauna with it (e.g. Rice and Greenberg 2000, Clough et al. 2011, Margono et al. 2012).

\subsection{Effects of shade tree removal and intensification in cacao agro-forestry systems}

The presence of shade trees in tropical agroforests is often assumed to affect growth and yield negatively through competitive resource use between crop and shade trees. On the one hand shade trees can enhance nutrient supply by additional $\mathrm{N}$ fixation through legume trees and by enhanced litter fall, root turnover and decomposition (e.g. Beer et al. 1998, Rice and Greenberg 2000, Bisseleua et al. 2009), but on the other hand they might be competing for water, light and nutrients with the crop (Beer 1987). The clearing of tropical forests for agricultural use and the intensification of already existing cultivation systems has significant consequences not only on a regional scale, but worldwide. Clearing of forests liberates carbon stored above- and belowground in leaves, branches, stems and roots as well as from the soil into the atmosphere (Baccini et al. 2012). Intensification of existing agricultural systems by shade tree removal and increased inputs of chemicals and labor adds further pressure on biological diversity and the ecosystems services provided by it (Benton et al. 2003). However, 
despite a possibly higher competition between crop and shade trees, several studies have shown that wildlife-friendly farming with higher biodiversity in terms of species richness does not necessarily lead to decreasing yields (e.g. Rice and Greenberg 2000, Wood and Lass 2001, Perfecto et al. 2005, Perfecto et al. 2007, Perfecto and Vandermeer 2010, Clough et al. 2011, Tscharntke et al. 2012). Moreover, there seem to be positive effects of ecosystem services provided by the shade trees for the crop trees such as enhanced biomass productivity coupled with higher resource-use efficiency, higher decomposition rates and better nutrient retention (Healy et al. 2008, Oelmann et al. 2010, Richards et al. 2010). Furthermore, agroforestry systems serve as an important carbon sink and help decrease pressure on natural forests (Montagini and Nair 2004) by providing additionally timber, fuel, fruits and plants for medicinal use. However, knowledge is weak regarding both the changes in net primary production (NPP) and the annual carbon sequestration resulting from forest conversion into agricultural systems (e.g. Leuschner et al. 2013) as well as from intensification and shade tree removal within different types of agricultural systems replacing natural forests (Ziegler et al. 2012). Furthermore, only few studies include belowground biomass, production and $\mathrm{C}$ storage, which may underestimate total C storage estimates (e.g. Jose et al. 2012, Leuschner et al. 2013, Saj et al. 2013). This is of special importance as root turnover is a crucial component of ecosystem nutrient and carbon sequestration, although they make up only a smaller part of total biomass (e. g. Cairns et al. 1997, Gill and Jackson 2000, Upadhaya et al. 2005). Despite roots playing an important role in terms of competition for water and nutrients, detailed studies about vertical root distribution and root dynamics in tropical land-use systems are still scarce. Competition for nutrients should be highest in the topsoil where most essential nutrients (especially $\mathrm{N}$ and P) are available (e.g. Varik et al. 2013). Indeed, several studies report that the majority of the cacao fine root biomass is located in the uppermost soil (e.g. Kummerow et al. 1982, Nygren and Leblanc 2009, Moser et al. 2010, Nygren et al. 2013), but studies about vertical rooting pattern and about possible belowground interactions between crop and shade tree species, which would help proofing of the occurrence of possible vertical root segregation are underrepresented: e.g. Schroth et al. 1996, Lehmann 2003, Ong et al. 2004, Ewel and Mazzarino 2008, Makumba et al. 2009, Moser et al. 2010, Schwendenmann et al. 2010. In agroforests, where farmers aim for high yields like cacao bean production, an optimal resource use-efficiency is crucial for high productivity. Schwendenmann et al. (2010) showed that cacao bean yield is negatively affected by low water availability. Water availability is especially important in the setting of global climatic change where dry periods are becoming more frequent and longer even in the moist tropical regions. Many shade tree species used in cacao agroforests are introduced from areas with severe dry seasons, like Gliricidia sepium (Jacq.) Kunth. 


\subsection{Tree growth as influenced by hydraulic architecture of roots, stems, and twigs}

In general, high aboveground biomass production has been related to several plant functional traits like high stem hydraulic efficiency, high foliar nitrogen content or low stems wood density (Brodribb et al. 2002, Tyree 2003, Zhang and Cao 2009, Hoeber et al. 2014). Trees with rapid wood growth were found to have rather lower wood density implying a lower hydraulic safety due to generally larger vessel size (Enquist et al. 1999, King et al. 2005, Poorter et al. 2010). In contrast, species with dense wood are considered to be more resistant to xylem cavitation, because of the common assumption that wood density and conduit size are positively correlated and thus, xylem wall thickness and resistance to cell wall implosion under negative pressure (Jacobsen et al. 2005). Subsequently, species with dense wood should show higher hydraulic safety at the cost of lower growth, which means lower productivity (Meinzer et al. 2003, Bucci et al. 2004). Considering the ecological relevance of the anatomical hydraulic properties, it is important to note that systematic studies on the ecological wood anatomy and hydraulic architecture of cacao and co-occurring shade tree species are lacking so far. As tropical agroforestry crop and shade tree species often originate from different biomes, they might possess distinct drought adaptations, but it is not clear if this implies differences in the hydraulic strategy of those crop and shade tree species. At present, there is no published information before this study on whether cacao and shade tree species with different biogeographical origin have developed similar hydraulic properties as the tree species of the natural forest which they replaced. Similarly, data is lacking on whether the hydraulic properties and wood density are related to the aboveground performance of crop and shade tree species.

\subsection{Project framework and study area}

This current study was embedded in the project 'Environmental and land-use change in Sulawesi, Indonesia (ELUC)'. It was conducted by several working groups of the Georg August University Göttingen (GAUG) in cooperation with Indonesian partners: Tadulako University in Palu, Sulawesi Tengah, and the Agricultural University in Bogor, Java. The aim of the ELUC project was to improve the understanding of the processes underlying environmental and land-use change in Indonesia as well as looking at the consequences of land-use change by smallholder farmers, who currently drive deforestation at the margin of the Lore Lindu National Park in terms of natural ecosystem services. The project was subdivided into 7 subprojects and the present doctoral thesis is composed by the subproject 'Shade trees in cacao agroforestry systems: influence on roots and net primary production' with funding provided by the German Research Foundation (DFG) acting within the framework of the ELUC as well as within the Collaborative Research Centre CRC990 (EFForTS: 'Ecological and Socioeconomic Functions of Tropical Lowland Rainforest Transformation Systems on Sumatra, Indonesia'). 
The study was carried out in the Kulawi valley in Central Sulawesi, Indonesia, where different cacao cultivation systems are still present adjacent to the Lore Lindu National Park (Fig. 1.3). In this area, three different cacao cultivation systems with different shade intensities could be investigated simultaneously and under equal climatic and soil conditions. Mean annual air temperature in the study region is $25^{\circ} \mathrm{C}$ and mean annual precipitation is $2165 \mathrm{~mm} \mathrm{yr}^{-1}$ (Köhler et al. 2014) with no distinct dry season during the study period (20112013).

To investigate the effects of cultivation intensification on above- and belowground biomass, NPP and related C stocks and C sequestration, as well as fine root dynamics, vertical root sequestration and hydraulic-anatomical wood properties, three different cacao agroforestry systems were chosen. Shade tree diversity and abundance increased from: 1) non-shaded cacao monoculture ('Cacao-mono') to 2) planted single-shade by Gliricidia sepium ('Cacao-Gliricidia') to 3) a multi-species shade tree layer ('Cacao-multi') (Fig. 1.4 AC). Three study plots of $20 \mathrm{~m}$ x $20 \mathrm{~m}$ per cultivation system type were distributed between the villages Marena and Lempelero in the southern part of the Kulawi valley (Fig. 1.3). More detailed information of the single plots about locational and soil characteristics as well as age, number of tree species and management during the study period from 2011-2013 is given in Table 1.1.

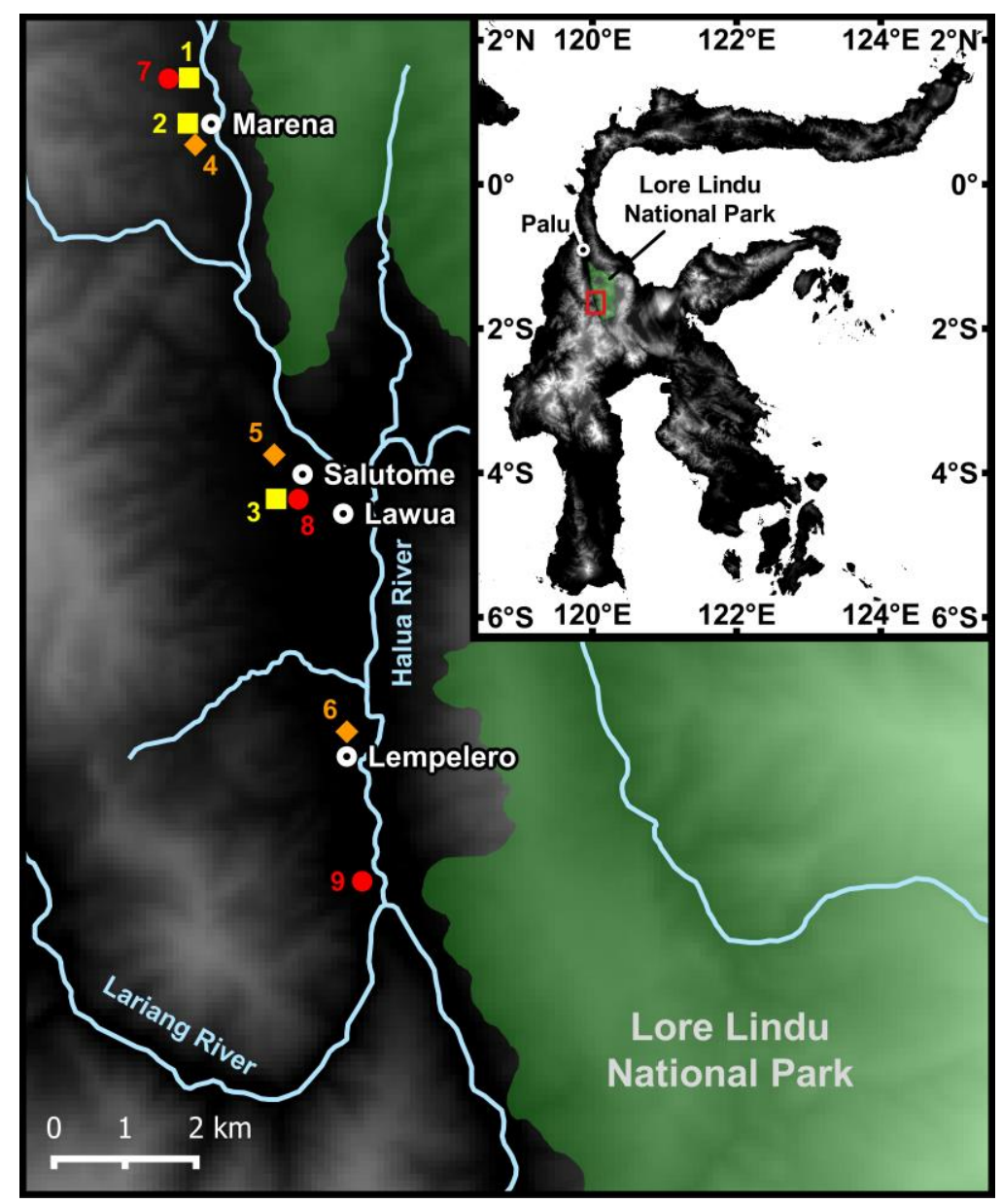

Figure 1.3: Map of the study region with the Lore Lindu National Park (green) and the Kulawi valley (red rectangle). Shown are the nine study sites distributed in the southern part of the Kulawi valley:

Plot 1-3: 'Cacao-mono'

Plot 3-6: 'Cacao-Gliricidia

Plot 6-9: 'Cacao-multi' 

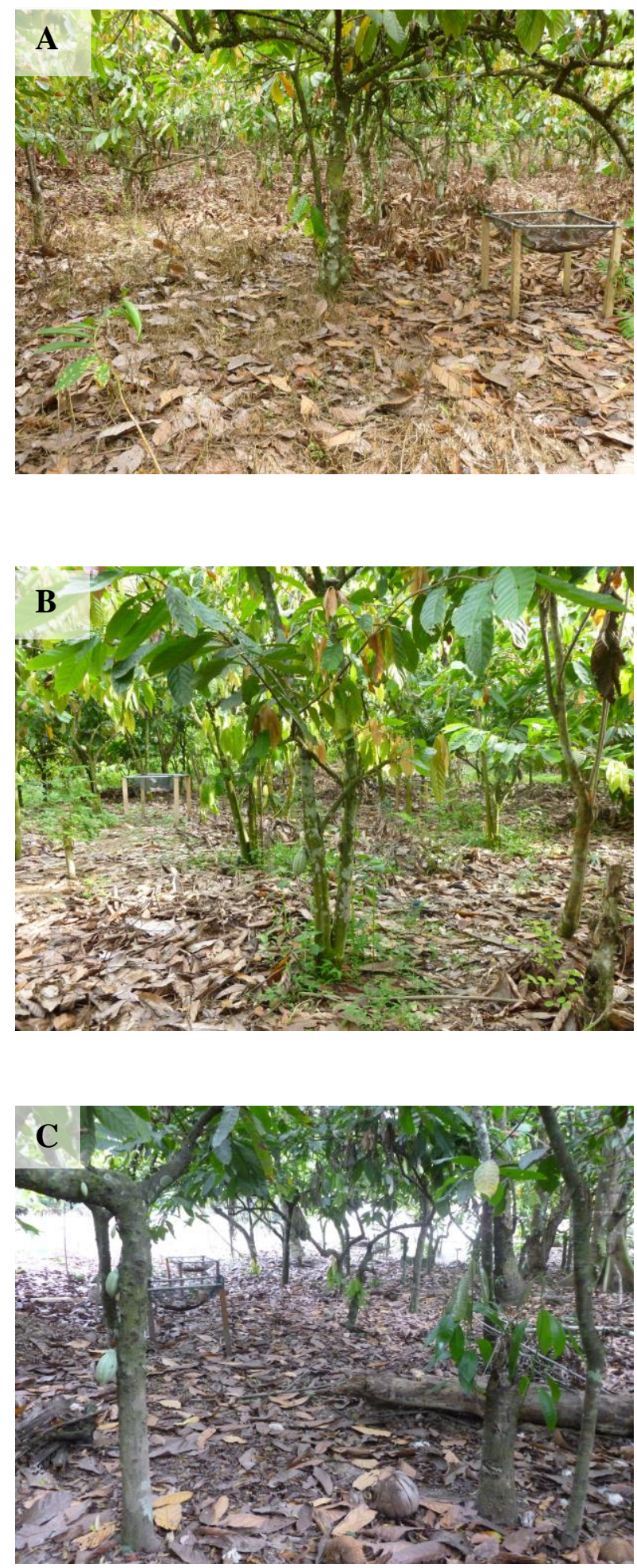

Figure 1.4: Different cacao cultivation systems:
A: Cacao monoculture ('Cacao-mono')
B: Cacao shaded by Gliricidia sepium ('Cacao-Gliricidia')
C: Cacao agroforest with a multi-species shade tree cover ('Cacao-multi') 


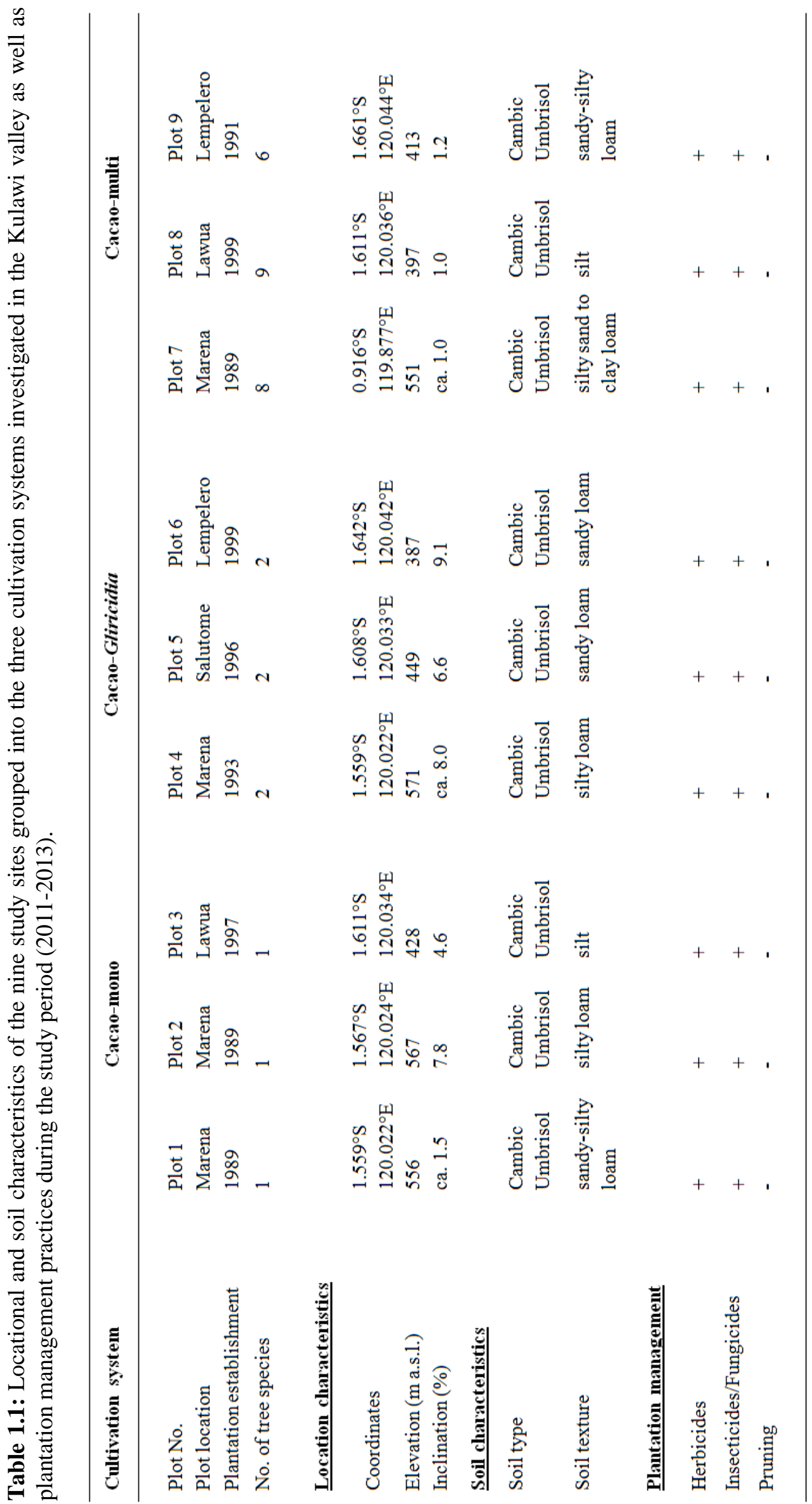




\subsection{Study objectives and general study aims}

General hypotheses of the present thesis were:

i) Above- and belowground biomass and NPP, as well as the related C stock and C sequestration increase with increasing shade tree cover.

ii) Cacao bean yield is negatively affected by an increasing shade tree cover.

iii) Standing fine root biomass, production and turnover increase with increasing shade tree cover.

iv) There is vertical root segregation between cacao and shade trees.

iv) Aboveground productivity is positively related to vessel size and hydraulic conductivity.

In order to investigate these hypotheses the following variables were assessed or estimated in the different cacao cultivation systems:

a) Aboveground stand structural inventory

b) Above- and belowground biomass and C-pools

c) Aboveground productivity and cacao bean yield (NPP)

d) The vertical distribution pattern of cacao and shade tree fine, large and coarse roots in the soil profile down to $300 \mathrm{~cm}$ soil depth

e) Fine root morphological traits in cacao and shade tree species in the whole $300 \mathrm{~cm}$ deep soil profile

f) The occurrence of 'deep roots' (roots present in soil depths below $100 \mathrm{~cm}$ )

g) Inventory of live and dead fine root biomass and the fine root production and turnover in the upper soil $(0-60 \mathrm{~cm}$ soil depth)

h) Assessment of possible complementary soil water uptake in cacao and shade trees using an approach of comparing natural deuterium abundance in the soil and in root and stem plant water of cacao and shade tree individuals (jointly conducted with the closely related project by Dirk Hölscher)

i) Hydraulic architecture and conductivity of root, stem and branch xylem tissue of cacao and shade trees

j) Chemical and physical soil properties $(0-60 \mathrm{~cm}$ soil depth) 


\subsection{Paper outline}

This dissertation is subdivided into three studies focusing on different aspects of biomass, productivity, root dynamics and distribution as well as hydraulic-anatomical properties in different cacao agroforestry systems.

\section{ChAPTER 2:}

\section{Cacao cultivation under diverse shade tree cover allows high carbon storage and} sequestration without yield losses

In this chapter, the three cultivation systems were compared with respect to above- and belowground biomass and the related carbon (C) stores, as well as $\mathrm{C}$ sequestration with above- and belowground net primary production (NPP). Furthermore, the role shaded cacao cultivation systems can play in the regional carbon cycle was assessed as well as the effect of shade trees on cacao bean yield.

The following hypotheses were tested:

(1) Increasing shade tree abundance and diversity increases above- and belowground carbon storage and productivity.

(2) Increasing shade tree cover decreases cacao bean yield.

\section{Chapter 3:}

\section{Abundance and diversity of shade trees in cacao agroforests (Indonesia) alters vertical rooting patterns and fine root dynamics}

In Chapter 3 the influence of shade trees on vertical rooting pattern and fine root dynamics of cacao and shade trees in the different agroforestry systems were analyzed. Standing biomass and vertical distribution of fine ( $<2 \mathrm{~mm}$ diameter), large (2-5 mm diameter), and coarse roots (> $5 \mathrm{~mm}$ diameter) as well as fine root dynamics on species level were assessed.

The following hypotheses were tested:

(1) Standing fine root biomass increases with increasing shade tree abundance and diversity.

(2) There is vertical root segregation between cacao and shade trees for more effective soil resource exploitation.

(3) Fine root production and turnover increases with increasing shade tree abundance and diversity. 


\section{CHAPTER 4:}

Patterns in hydraulic architecture from roots to branches in six tropical tree species from cacao agroforestry and their relation to wood density and stem growth

In this study the interrelationship between sapwood area and specific hydraulic conductivity of root, stem and branch xylem tissue with wood anatomical traits along the water flow path across six common cacao agroforestry tree species with different biogeographical origins were examined. Moreover, the aboveground growth performance was related to hydraulic efficiency, stem wood density, foliar nitrogen content and foliar $\delta^{13} \mathrm{C}$ of these species.

The following hypotheses were tested:

(1) In contrast to temperate tree species - the largest vessels along the water flow path are found in the stem xylem and not in the roots.

(2) Stem xylem hydraulic properties are unrelated to stem wood density.

(3) Aboveground productivity across species is positively related to vessel size and hydraulic conductivity.

\section{References}

Achard, F., H. D. Eva, H.-J. Stibig, P. Mayaux, J. Gallego, T. Richards, and J.-P. Malingreau. 2002. Determination of deforestation rates of the world's humid tropical forests. Science 297:999-1002.

Almeida, A.-A., and R. Valle. 2007. Ecophysiology of the cacao tree. Brazilian Journal of Plant Physiology 19:425-448.

Aneja, M., T. Gianfagna, and E. Ng. 1999. The roles of abscisic acid and ethylene in the abscission and senescence of cocoa flowers. Plant Growth Regulation 27:149-155.

Baccini, A., S. Goetz, W. Walker, N. T. Laporte, M. Sun, D. Sulla-Menashe, J. Hackler, P. S. A. Beck, R. Dubayah, M. A. Friedl, S. Samanta, and R. A. Houghton. 2012. Estimated carbon dioxide emissions from tropical deforestation improved by carbon-density maps. Nature Climate Change 2:182-185.

Beer, J. 1987. Advantages, disadvantages and desirable characteristics of shade trees for coffee, cacao and tea. Agroforestry systems 5:3-13.

Beer, J., R. Muschler, D. Kass, and E. Somarriba. 1998. Shade management in coffee and cacao plantations. Agroforestry Systems 38:139-164.

Belsky, J., and S. Siebert. 2003. Cultivating cacao: Implications of sun-grown cacao on local food security and environmental sustainability. Agriculture and Human Values 20:277285. 
Benton, T., J. Vickery, and J. Wilson. 2003. Farmland biodiversity: is habitat heterogeneity the key? Trends in Ecology \& Evolution 18:182-188.

Bisseleua, D., A. Missoup, and S. Vidal. 2009. Biodiversity conservation, ecosystem functioning, and economic incentives under cocoa agroforestry intensification. Conservation Biology 23:1176-1184.

Bowers, J. H., B. A. Bailey, P. K. Hebbar, S. Sanogo, and R. D. Lumsden. 2001. The Impact of Plant Diseases on World Chocolate Production. Online. Plant Health Progress:1-17.

Brodribb, T. J., N. M. Holbrook, and M. V Gutierrez. 2002. Hydraulic and photosynthetic coordination in seasonally dry tropical forest trees. Plant, Cell \& Environment 25:14351444.

Bucci, S. J., G. Goldstein, F. C. Meinzer, F. G. Scholz, a C. Franco, and M. Bustamante. 2004. Functional convergence in hydraulic architecture and water relations of tropical savanna trees: from leaf to whole plant. Tree physiology 24:891-899.

Cheesman, E. E. 1944. Notes on the nomenclature, classification and possible relationships of cacao populations. Tropical Agriculture 21:144-159.

Clement, C. R., M. de Cristo-Araújo, G. C. D’Eeckenbrugge, A. Alves Pereira, and D. Picanço-Rodrigues. 2010. Origin and Domestication of Native Amazonian Crops. Diversity 2:72-106.

Clough, Y., J. Barkmann, J. Juhrbandt, M. Kessler, T. C. Wanger, A. Anshary, D. Buchori, D. Cicuzza, K. Darras, D. D. Putra, S. Erasmi, R. Pitopang, C. Schmidt, C. H. Schulze, D. Seidel, I. Steffan-Dewenter, K. Stenchly, S. Vidal, M. Weist, A. C. Wielgoss, and T. Tscharntke. 2011. Combining high biodiversity with high yields in tropical agroforests. Proceedings of the National Academy of Sciences of the United States of America 108:8311-8316.

Clough, Y., H. Faust, and T. Tscharntke. 2009. Cacao boom and bust: sustainability of agroforests and opportunities for biodiversity conservation. Conservation Letters 2:197205.

Culmsee, H., C. Leuschner, G. Moser, and R. Pitopang. 2010. Forest aboveground biomass along an elevational transect in Sulawesi, Indonesia, and the role of Fagaceae in tropical montane rain forests. Journal of Biogeography 37:960-974.

Day, R. K. 1989. Effect of cocoa pod borer, Conopomorpha cramerella, on cocoa yield and quality in Sabah, Malaysia. Crop Protection 8:332-339.

DeFries, R., F. Achard, S. Brown, M. Herold, D. Murdiyarso, B. Schlamadinger, and C. de Souza Jr. 2007. Earth observations for estimating greenhouse gas emissions from deforestation in developing countries. Environmental science \& Policy 10:385-394.

DeFries, R., R. A. Houghton, M. C. Hansen, C. B. Field, D. Skole, and J. Townshend. 2002. Carbon emissions from tropical deforestation and regrowth based on satellite observations for the 1980s and 1990s. Proceedings of the National Academy of Sciences 
of the United States of America 99:14256-14261.

Enquist, B. J., G. B. West, E. L. Charnov, J. H. Brown, T. Santa, H. P. Road, S. Fe, T. Division, and B. Ms. 1999. Allometric scaling of production and life history variation in vascular plants. Nature 401:907-911.

Ewel, J., and M. Mazzarino. 2008. Competition from below for light and nutrients shifts productivity among tropical species. Proceedings of the National Academy of Sciences of the United States of America 105:18836-18841.

Fan, Z.-X., S.-B. Zhang, G.-Y. Hao, J. W. Ferry Slik, and K.-F. Cao. 2012. Hydraulic conductivity traits predict growth rates and adult stature of 40 Asian tropical tree species better than wood density. Journal of Ecology 100:732-741.

FAO Statistical Databases: http://faostat.fao.org (Accessed Nov 2015)

Foley, J. A., R. DeFries, G. P. Asner, C. Barford, G. Bonan, S. R. Carpenter, F. S. Chapin, M. T. Coe, G. C. Daily, H. K. Gibbs, J. H. Helkowski, T. Holloway, E. A. Howard, C. J. Kucharik, C. Monfreda, J. A. Patz, I. C. Prentice, N. Ramankutty, and P. K. Snyder. 2005. Global consequences of land use. Science (New York, N.Y.) 309:570-4.

Foroughbakhch, R., M. A. Alvarado-Vázquez, J. L. Hernández-Piñero, A. Rocha-Estrada, M. A. Guzmán-Lucio, and E. J. Treviño-Garza. 2006. Establishment, growth and biomass production of 10 tree woody species introduced for reforestation and ecological restoration in northeastern Mexico. Forest Ecology and Management 235:194-201.

Frimpong, E., B. Gemmill-Herren, I. Gordon, and P. K. Kwapong. 2011. Dynamics of insect pollinators as influenced by cocoa production systems in Ghana. Journal of Pollination Ecology 5:74-80.

Gill, R., and R. Jackson. 2000. Global patterns of root turnover for terrestrial ecosystems. New Phytologist 147:13-31.

Gilroy, J. J., F. A. Edwards, C. A. Medina Uribe, T. Haugaasen, and D. P. Edwards. 2014. Surrounding habitats mediate the trade-off between land-sharing and land-sparing agriculture in the tropics. Journal of Applied Ecology 51:1337-1346.

Groeneveld, J. H., T. Tscharntke, G. Moser, and Y. Clough. 2010. Experimental evidence for stronger cacao yield limitation by pollination than by plant resources. Perspectives in Plant Ecology, Evolution and Systematics 12:183-191.

Hansen, M. C., and R. S. DeFries. 2004. Detecting Long-term Global Forest Change Using Continuous Fields of Tree-Cover Maps from 8-km Advanced Very High Resolution Radiometer (AVHRR) Data for the Years 1982-99. Ecosystems 7:695-716.

Hansen, M. C., P. V. Potapov, R. Moore, M. Hancher, S. A. Turubanova, A. Tyukavina, D. Thau, S. V. Stehman, S. J. Goetz, T. R. Loveland, A. Kommareddy, A. Egorov, L. Chini, C. O. Justice, and J. R. G. Townshend. 2013. High-resolution global maps of 21stcentury forest cover change. Science 342:850-3. 
Harris, N. L., S. Brown, S. C. Hagen, S. S. Saatchi, S. Petrova, W. Salas, M. C. Hansen, P. V. Potapov, and A. Lotsch. 2012. Baseline map of carbon emissions from deforestation in tropical regions. Science 336:1573-1576.

Healy, C., N. J. Gotelli, and C. Potvin. 2008. Partitioning the effects of biodiversity and environmental heterogeneity for productivity and mortality in a tropical tree plantation. Journal of Ecology 96:903-913.

Henderson, J. S., R. A. Joyce, G. R. Hall, W. J. Hurst, and P. E. McGovern. 2007. Chemical and archaeological evidence for the earliest cacao beverages. Proceedings of the National Academy of Sciences of the United States of America 104:18937-18940.

Hoeber, S., C. Leuschner, L. Köhler, D. Arias-Aguilar, and B. Schuldt. 2014. The importance of hydraulic conductivity and wood density to growth performance in eight tree species from a tropical semi-dry climate. Forest Ecology and Management 330:126-136.

Houghton, R. A., D. L. Skole, C. A. Nobre, J. L. Hackler, K. T. Lawrence, and W. H. Chomentowski. 2000. Annual fluxes of carbon from deforestation and regrowth in the Brazilian Amazon. Nature 403:301-304.

Jacobsen, A. L., F. W. Ewers, R. B. Pratt, W. A. Paddock III, and S. D. Davis. 2005. Do Xylem Fibers Affect Vessel Cavitation Resistance? Plant Physiology 139:546-556.

King, D. A., S. J. Davies, M. N. N. Supardi, and S. Tan. 2005. Tree growth is related to light interception and wood density in two mixed dipterocarp forests of Malaysia. Functional Ecology 19:445-453.

Köhler, M., A. Hanf, H. Barus, Hendrayanto, and D. Hölscher. 2014. Cacao trees under different shade tree shelter: effects on water use. Agroforestry systems 88:63-73.

Kummerow, J., M. Kummerow, and W. da Silva. 1982. Fine-root growth dynamics in cacao (Theobroma cacao). Plant and Soil 65:193-201.

Kunert, N., and A. Cárdenas. 2015. Are Mixed Tropical Tree Plantations More Resistant to Drought than Monocultures? Forests 6:2029-2046.

Lachenaud, P., V. Mooleedhar, and C. Couturier. 1997. Les cacaoyers spontanés de Guyane. Nouvelles prospections. Plantations, recherche, développement 4:25-32.

Lehmann, J. 2003. Subsoil root activity in tree-based cropping systems. Plant and Soil 255:319-331.

Leuschner, C., G. Moser, D. Hertel, S. Erasmi, D. Leitner, H. Culmsee, B. Schuldt, and L. Schwendenmann. 2013. Conversion of tropical moist forest into cacao agroforest: consequences for carbon pools and annual C sequestration. Agroforestry Systems 87:1173-1187.

Lewis, S. L., D. P. Edwards, D. Galbraith. 2015. Increasing human dominance of tropical forests. Science 359:827-32. 
Livesley, S. J., P. J. Gregory, and R. J. Buresh. 2000. Competition in tree row agroforestry systems. 1. Distribution amd dynamics of fine root length and biomass. Plant and Soil 227:149-161.

Makumba, W., F. K. Akinnifesi, and B. H. Janssen. 2009. Spatial rooting patterns of gliricidia, pigeon pea and maize intercrops and effect on profile soil $\mathrm{N}$ and $\mathrm{P}$ distribution in southern Malawi. African Journal of Agricultural Research 4:278-288.

Margono, B. A., P. V. Potapov, S. Turubanova, F. Stolle, and M. Hansen. 2014. Primary forest cover loss in Indonesia over 2000-2012. Nature Climate Change 4:1-6.

Margono, B. A., S. Turubanova, I. Zhuravleva, P. Potapov, A. Tyukavina, A. Baccini, S. Goetz, and M. C. Hansen. 2012. Mapping and monitoring deforestation and forest degradation in Sumatra (Indonesia) using Landsat time series data sets from 1990 to 2010. Environmental Research Letters 7:034010.

Meinen, C., D. Hertel, and C. Leuschner. 2009. Root growth and recovery in temperate broadleaved forest stands differing in tree species diversity. Ecosystems 12:1103-1116.

Meinzer, F. C., S. A. James, G. Goldstein, and D. Woodruff. 2003. Whole-tree water transport scales with sapwood capacitance in tropical forest canopy trees. Plant, Cell and Environment 26:1147-1155.

Miettinen, J., C. Shi, and S. C. Liew. 2011. Deforestation rates in insular Southeast Asia between 2000 and 2010. Global Change Biology 17:2261-2270.

Montagnini, F., and P. Nair. 2004. Carbon sequestration: an underexploited environmental benefit of agroforestry systems. Agroforestry systems 61:281-295.

Moser, G., C. Leuschner, D. Hertel, D. Hölscher, M. Köhler, D. Leitner, B. Michalzik, E. Prihastanti, S. Tjitrosemito, and L. Schwendenmann. 2010. Response of cocoa trees (Theobroma cacao) to a 13-month desiccation period in Sulawesi, Indonesia. Agroforestry Systems 79:171-187.

Motamayor, J. C., A. M. Risterucci, P. A. Lopez, C. F. Ortiz, A. Moreno, and C. Lanaud. 2002. Cacao domestication I: the origin of the cacao cultivated by the Mayas. Heredity 89:380-386.

Myers, N., and R. Mittermeier. 2000. Biodiversity hotspots for conservation priorities. Nature 403.

Nygren, P., and H. Leblanc. 2009. Natural abundance of $15 \mathrm{~N}$ in two cacao plantations with legume and non-legume shade trees. Agroforestry systems 76:303-315.

Nygren, P., H. Leblanc, M. Lu, and C. Luciano. 2013. Distribution of coarse and fine roots of Theobroma cacao and shade tree Inga edulis in a cocoa plantation. Annals of forest science 70:229-239. 
Oelmann, Y., C. Potvin, T. Mark, L. Werther, S. Tapernon, and W. Wilcke. 2010. Tree mixture effects on aboveground nutrient pools of trees in an experimental plantation in Panama. Plant and Soil 326:199-212.

Ong, C. K., R. M. Kho, and S. Radersma. 2004. Ecological interactions in multispecies agroecosystems: concepts and rules. CABI Publishing, Wallingford.

Perfecto, I., I. Armbrecht, S. M. Philpott, L. Soto-Pinto, and T. V Dietsch. 2007. Shaded coffee and the stability of rainforest margins in northern Latin America. Pages 227-263 Stability of Tropical Rainforest Margins: Linking Ecological, Economic and Social Constraints of Land Use and Conservation.

Perfecto, I., and J. Vandermeer. 2010. The agroecological matrix as alternative to the landsparing/agriculture intensification model. Proceedings of the National Academy of Sciences of the United States of America 107:5786-5791.

Perfecto, I., J. Vandermeer, A. Mas, and L. Soto-Pinto. 2005. Biodiversity, yield, and shade coffee certification. Ecological Economics 54:435-446.

Poorter, L., I. McDonald, A. Alarcón, E. Fichtler, J. C. Licona, M. Peña-Claros, F. Sterck, Z. Villegas, and U. Sass-Klaassen. 2010. The importance of wood traits and hydraulic conductance for the performance and life history strategies of 42 rainforest tree species. New Phytologist 185:481-492.

Powis, T. G., A. Cyphers, N. W. Gaikwad, L. Grivetti, and K. Cheong. 2011. Cacao use and the San Lorenzo Olmec. Proceedings of the National Academy of Sciences of the United States of America 108:8595-8600.

Rice, R. A., and R. Greenberg. 2000. Cacao Cultivation and the Conservation of Biological Diversity. Ambio: A Journal of the Human Environment 29:167-173.

Richards, A. E., D. I. Forrester, J. Bauhus, and M. Scherer-Lorenzen. 2010. The influence of mixed tree plantations on the nutrition of individual species: A review. Tree Physiology 30:1192-1208.

Russo, S. E., K. L. Jenkins, S. K. Wiser, M. Uriarte, R. P. Duncan, and D. A. Coomes. 2010. Interspecific relationships among growth, mortality and xylem traits of woody species from New Zealand. Functional Ecology 24:253-262.

Saatchi, S. S., N. L. Harris, S. Brown, M. Lefsky, E. T. A. Mitchard, W. Salas, B. R. Zutta, W. Buermann, S. L. Lewis, S. Hagen, S. Petrova, L. White, M. Silman, and A. Morel. 2011. Benchmark map of forest carbon stocks in tropical regions across three continents. Proceedings of the National Academy of Sciences of the United States of America 108:9899-904.

dos Santos Dias, L. A., and P. Y. Kageyama. 1997. Temporal stability of multivariate genetic divergence in cacao (Theobroma cacao L.) in Southern Bahia conditions. Euphytica 93:181-187. 
Schroth, G., D. Kolbe, B. Pity, and W. Zech. 1996. Root system characteristics with agroforestry relevance of nine leguminous tree species and a spontaneous fallow in a semi-deciduous rainforest area of West Africa. Forest Ecology and Management 84:199_ 208.

Schuldt, B., C. Leuschner, N. Brock, and V. Horna. 2013. Changes in wood density, wood anatomy and hydraulic properties of the xylem along the root-to-shoot flow path in tropical rainforest trees. Tree Physiology 33:161-174.

Schwendenmann, L., E. Veldkamp, G. Moser, D. Hölscher, M. Köhler, Y. Clough, I. Anas, G. Djajakirana, S. Erasmi, D. Hertel, D. Leitner, C. Leuschner, B. Michalzik, P. Propastin, A. Tjoa, T. Tscharntke, and O. van Straaten. 2010. Effects of an experimental drought on the functioning of a cacao agroforestry system, Sulawesi, Indonesia. Global Change Biology 16:1515-1530.

Siebert, S. F. 2002. From shade- to sun-grown perennial crops in Sulawesi, Indonesia: Implications for biodiversity conservation and soil fertility. Biodiversity and Conservation 11:1889-1902.

Sodhi, N. S., L. P. Koh, B. W. Brook, and P. K. L. Ng. 2004. Southeast Asian biodiversity: An impending disaster. Trends in Ecology and Evolution 19:654-660.

Steffan-Dewenter, I., M. Kessler, J. Barkmann, M. M. Bos, D. Buchori, S. Erasmi, H. Faust, G. Gerold, K. Glenk, S. R. Gradstein, E. Guhardja, M. Harteveld, D. Hertel, P. Höhn, M. Kappas, S. Köhler, C. Leuschner, M. Maertens, R. Marggraf, S. Migge-Kleian, J. Mogea, R. Pitopang, M. Schaefer, S. Schwarze, S. G. Sporn, A. Steingrebe, S. S. Tjitrosoedirdjo, S. Tjitrosemito, A. Twele, R. Weber, L. Woltmann, M. Zeller, and T. Tscharntke. 2007. Tradeoffs between income, biodiversity, and ecosystem functioning during tropical rainforest conversion and agroforestry intensification. Proceedings of the National Academy of Sciences of the United States of America 104:4973-4978.

Susilo, A. W., D. Zhang, L. A. Motilal, S. Mischke, and L. W. Meinhardt. 2011. Assessing Genetic Diversity in Java Fine-Flavor Cocoa (Theobroma cacao L.) Germplasm by Using Simple Sequence Repeat (SSR) Markers. Trop. Agr. Develop 55:84-92.

Tscharntke, T., Y. Clough, S. A. Bhagwat, D. Buchori, H. Faust, D. Hertel, D. Hölscher, J. Juhrbandt, M. Kessler, I. Perfecto, C. Scherber, G. Schroth, E. Veldkamp, and T. C. Wanger. 2011. Multifunctional shade-tree management in tropical agroforestry landscapes - A review. Journal of Applied Ecology 48:619-629.

Tscharntke, T., Y. Clough, T. C. Wanger, L. Jackson, I. Motzke, I. Perfecto, J. Vandermeer, and A. Whitbread. 2012. Global food security, biodiversity conservation and the future of agricultural intensification. Biological Conservation 151:53-59.

Tyree, M. T. 2003. Hydraulic limits on tree performance: transpiration, carbon gain and growth of trees. Trees-Structure and Function 17:95-100. 
Upadhaya, K., H. N. Pandey, P. S. Law, and R. S. Tripathi. 2005. Dynamics of fine and coarse roots and nitrogen mineralization in a humid subtropical forest ecosystem of northeast India. Biology and Fertility of Soils 41:144-152.

Varik, M., J. Aosaar, I. Ostonen, K. Lõhmus, and V. Uri. 2013. Carbon and nitrogen accumulation in belowground tree biomass in a chronosequence of silver birch stands. Forest Ecology and Management 302:62-70.

Wade, A. S. I., A. Asase, P. Hadley, J. Mason, K. Ofori-Frimpong, D. Preece, N. Spring, and K. Norris. 2010. Management strategies for maximizing carbon storage and tree species diversity in cocoa-growing landscapes. Agriculture, Ecosystems and Environment 138:324-334.

Weber, R., H. Faust, S. Bjorn, S. Mamar, E. Sutarto, and W. Kreisel. 2007. Migration and ethnicity as cultural impact factors on land use change in the rainforest margins of Central Sulawesi , Indonesia. Pages 417-436 in T. Tscharntke, C. Leuschner, M. Zeller, E. Guhardja, and A. Bidin, editors. The stability of tropical reinforest margins, linking ecological, economic and social constrains of land use and conservation. Springer Netherlands, Berlin.

Van der Werf, G. R., D. C. Morton, R. S. DeFries, J. G. J. Olivier, P. S. Kasibhatla, R. B. Jackson, G. J. Collatz, and J. T. Randerson. 2009. CO2 emissions from forest loss. Nature Geoscience 2:9-11.

Wilcove, D. S., X. Giam, D. P. Edwards, B. Fisher, and L. P. Koh. 2013. Navjot's nightmare revisited: Logging, agriculture, and biodiversity in Southeast Asia. Trends in Ecology and Evolution 28:531-540.

Wood, G. A. R., and R. A. Lass. 2001. Cocoa. 4th ed. Blackwell Science.

Young, A. M. 1982. Effects of Shade Cover and Availability of Midge Breeding Sites on Pollinating Midge Populations and Fruit Set in Two Cocoa Farms. Journal of Applied Ecology 19:47-63.

Zhang, J.-L., and K.-F. Cao. 2009. Stem hydraulics mediates leaf water status, carbon gain, nutrient use efficiencies and plant growth rates across dipterocarp species. Functional Ecology 23:658-667.

Ziegler, A. D., J. Phelps, J. Q. Yuen, E. L. Webb, D. Lawrence, J. M. Fox, T. B. Bruun, S. J. Leisz, C. M. Ryan, W. Dressler, O. Mertz, U. Pascual, C. Padoch, and L. P. Koh. 2012. Carbon outcomes of major land-cover transitions in SE Asia: Great uncertainties and REDD+ policy implications. Global Change Biology 18:3087-3099. 


\section{CHAPTER 2}

Cacao cultivation under diverse shade tree cover allows high carbon storage and sequestration without yield losses

Yasmin ABou Rajab, Christoph Leuschner, Henry Barus, Aiyen TJOA, and Dietrich HERTEL

PloS one, 11(2), e0149949 


\subsection{Abstract}

One of the main drivers of tropical forest loss is their conversion to oil palm, soy or cacao plantations with low biodiversity and greatly reduced carbon storage. Southeast Asian cacao plantations are often established under shade tree cover, but are later converted to non-shaded monocultures to avoid resource competition. We compared three co-occurring cacao cultivation systems (3 replicate stands each) with different shade intensity (non-shaded monoculture, cacao with the legume Gliricidia sepium shade trees, and cacao with several shade tree species) in Sulawesi (Indonesia) with respect to above- and belowground biomass and productivity, and cacao bean yield. Total biomass $\mathrm{C}$ stocks (above- and belowground) increased fivefold from the monoculture to the multi-shade tree system (from 11 to $57 \mathrm{Mg} \mathrm{ha}{ }^{-}$

${ }^{1}$ ), total net primary production rose twofold (from 9 to $18 \mathrm{Mg} \mathrm{C} \mathrm{ha}^{-1} \mathrm{yr}^{-1}$ ). This increase was associated with a 6 fold increase in aboveground biomass, but only a 3.5 fold increase in root biomass, indicating a clear shift in $\mathrm{C}$ allocation to aboveground tree organs with increasing shade for both cacao and shade trees. Despite a canopy cover increase from 50 to $93 \%$, cacao bean yield remained invariant across the systems (variation: 1.1-1.2 $\mathrm{Mg} \mathrm{C} \mathrm{ha}^{-1} \mathrm{yr}^{-1}$ ). The monocultures had a twice as rapid leaf turnover suggesting that shading reduces the exposure of cacao to atmospheric drought, probably resulting in greater leaf longevity. Thus, contrary to general belief, cacao bean yield does not necessarily decrease under shading which seems to reduce physical stress. If planned properly, cacao plantations under a shade tree cover allow combining high yield with benefits for carbon sequestration and storage, production system stability under stress, and higher levels of animal and plant diversity.

Key words: Biodiversity, agroforestry, carbon pools, net primary production, aboveground biomass, belowground biomass, shade, cacao bean yield 


\subsection{Introduction}

Tropical deforestation and decreasing carbon sinks are one of the major threats increasing the concentration of atmospheric carbon dioxide $\left(\mathrm{CO}_{2}\right)$, thereby enforcing global climate change (e.g. Houghton et al. 2000, DeFries et al. 2002, Achard et al. 2002, DeFries et al. 2007, Miettinen et al. 2011). A current hotspot of rainforest conversion is Southeast Asia and in particular Indonesia (Achard et al. 2002, Miettinen et al. 2011, Saatchi et al. 2011, Margono et al. 2012, Hansen et al. 2013), which lost $\sim 158,000 \mathrm{~km}^{2}$ of its forest cover between 2000 and 2012 (Hansen et al. 2013, Margono et al. 2014). Indonesia's carbon emissions reached $105 \mathrm{Tg} \mathrm{C} \mathrm{yr}^{-1}$ between 2000 and 2005 (Harris et al. 2012) and the nation is the world's third largest $\mathrm{CO}_{2}$ emitter by now (Margono et al. 2014). Main driver of deforestation in this region is the conversion into agricultural cultivation systems (e.g. Achard et al. 2002, Margono et al. 2012, Margono et al. 2014, Wilcove et al. 2013), notably palm oil, cocoa, and rubber. Cacao (Theobroma cacao L.) is a crop of the humid tropical lowlands which is mostly grown by smallholders. Due to the steadily increasing demand for chocolate (Rice and Greenberg 2000, Bisseleua et al. 2009), the world cocoa production has increased to $\sim 5$ million $\mathrm{t}$ in 2012 (FAO Statistical Database; http://faostat.fao.org) and cacao ranges currently as one of the most important perennial cash crops worldwide. In Sulawesi (Indonesia), where this study was conducted, the cultivation area of cacao expanded rapidly in the 1980s and 1990s; about $50 \%$ of the recent cacao cultivation area is located on former forested land (Rice and Greenberg 2000). Within the Indonesian archipelago, about $65 \%$ of Indonesia's cacao production is generated on Sulawesi (Clough et al. 2009, Leuschner et al. 2013). Since cacao is an understory rainforest species, it has traditionally been planted beneath the thinned canopy of primary or old secondary forest (Rice and Greenberg 2000). In Indonesia, this traditional cultivation system has increasingly been altered by removing the shade trees. In many cases, fast-growing and nitrogen-fixing shade trees like Gliricidia ssp. or Erythrina ssp., or trees which provide edible fruits, timber or other valuable goods were planted instead. Due to the shade requirement of young cacao plants, cacao is still cultivated under shade tree cover in the first years. But nowadays, shade trees are often completely removed when the cacao matures, because farmers wish to increase cacao bean yield (e.g. Rice and Greenberg 2000, Siebert 2002, Belsky and Siebert 2003, Steffan-Dewenter et al. 2007, Bisseleua et al. 2009, Tscharntke et al. 2011). The rationale is to reduce assumed competition for light, water and nutrients between cacao and shade trees (e.g. Rice and Greenberg 2000, Belsky and Siebert 2003, Schwendenmann et al. 2010). This change in cultivation practice may have a number of negative consequences, notably losses in biodiversity, increased soil erosion due to diminished protection from heavy rain, and largely reduced carbon storage in biomass (e.g. Beer et al. 1998, Rice and Greenberg 2000, Montagini and Nair 2004). Moreover, various monetary and non-monetary ecosystem services provided by the shade trees are no longer available to the local community, among them the supply of timber, fuel, and fruit production (Tscharntke et al. 2011). Even though recent research in tropical agroforests has addressed 
these benefits, not much is known about differences in carbon storage and carbon sequestration through net primary production (NPP) in cacao agroforests differing in shade tree cover and diversity. Even fewer studies have dealt with belowground carbon stores and $\mathrm{C}$ turnover of cacao agroforests and their dependence on variation in canopy cover.

The aim of the present study was to compare cacao cultivation systems from zero to high shade intensity with respect to biomass, carbon stores and productivity. In a region of Central Sulawesi with rapid expansion of cacao cultivation in recent time, where shaded and nonshaded cacao production systems co-occur in close neighborhood, we compared three widespread systems (non-shaded cacao monoculture, cacao with the legume Gliricidia sepium (Jacq.) Kunth as dominant shade tree, and cacao with relatively dense cover of several shade tree species) with respect to above- and belowground biomass and related carbon (C) stores, and $\mathrm{C}$ sequestration with above- and belowground net primary production (NPP) in each three replicate plots. We tested the hypotheses that (1) increasing shade tree abundance and diversity increases above- and belowground carbon storage and productivity, and that (2) increasing shade tree cover decreases cacao bean yield. By quantifying the biomass carbon pools and NPP of the different systems and comparing it with natural forest, we further wanted to assess the role shaded cacao cultivation systems can play in the regional carbon cycle. To our knowledge, this is the first study which investigates three co-existing cacao cultivation systems (structurally simple monoculture to complex multi-species agroforest) under equal climatic and soil conditions with a focus on the carbon cycle and cacao bean yield.

\subsection{Materials and Methods}

\section{Study site description and study plot selection}

The study was conducted in the Kulawi valley in Central Sulawesi, Indonesia, at the Western border of Lore Lindu National Park (013’S, $120^{\circ} 02^{\prime} \mathrm{E}$ ) (Fig 2.1). Annual mean temperature in the region was $25^{\circ} \mathrm{C}$, annual mean precipitation $2165 \mathrm{~mm} \mathrm{yr}^{-1}$ (Köhler et al. 2014) without a distinct seasonality during the study time. We studied three different cacao cultivation systems, (i) monoculture of cacao (Theobroma cacao L.) ('Cacao-mono'), (ii) cacao planted with the N-fixing legume tree Gliricidia sepium (Jacq.) Kunth ('Cacao-Gliricidia'), and (iii) cacao cultivated with several different shade tree species ('Cacao-multi'). Three study plots of approx. $20 \mathrm{~m}$ x $20 \mathrm{~m}$ per cultivation system type were selected between the villages Marena and Lempelero in the South of Kulawi valley (Fig 2.1 and Table 2.1). Apart from the necessary agreement of the plot owners, plot selection criteria were sufficient comparability in terms of topography (only low inclination), soil texture (sandy to clayey loam) and chemistry (Cambic Umbrisols with comparable $\mathrm{pH}$, base saturation and $\mathrm{C} / \mathrm{N}$ ratio, Table 2.1). Soil chemical parameters were measured from six randomly selected soil samples taken at each study site with a soil corer $(5 \mathrm{~cm}$ in diameter) down to a depth of $60 \mathrm{~cm}$. The total carbon and nitrogen concentrations were determined by gas chromatography, the total $\mathrm{P}$ concentration 
with ICP-OES analysis after $\mathrm{HNO}_{3}$ digestion, the plant-available cation concentrations after $\mathrm{NH}_{4} \mathrm{Cl}$ extraction and subsequent element analysis in the percolate by ICP-OES. To estimate the total carbon pool in the upper $60 \mathrm{~cm}$ of the soil, we used data of the bulk density of the soil and the soil organic carbon content. Large variation was found for available P (resin P) which may partly be a result of different time spans since the last fertilization in the plots.

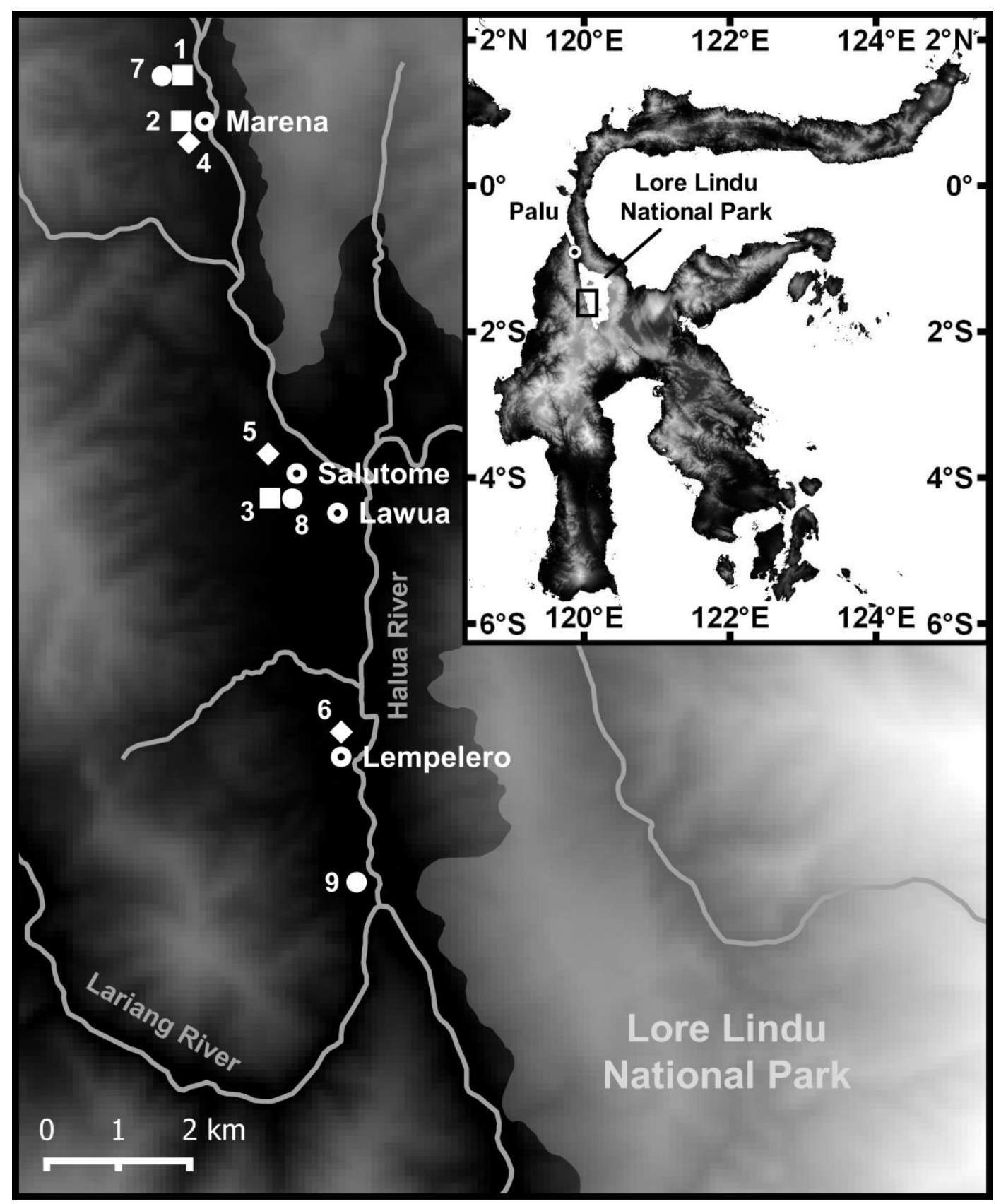

Figure 2.1: Map of the study region 
昰言 o 目

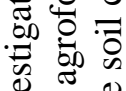

일

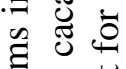
는 人。 휼

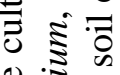

을 해을

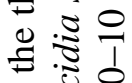
옿 을 言高 (1) 要

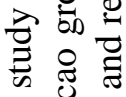
을 部泀言

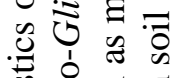

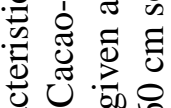
记

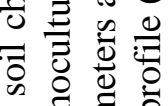
焉焉 . 政

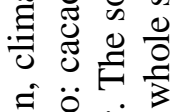
彭言离 영

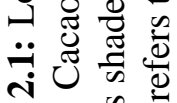

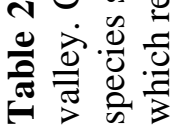

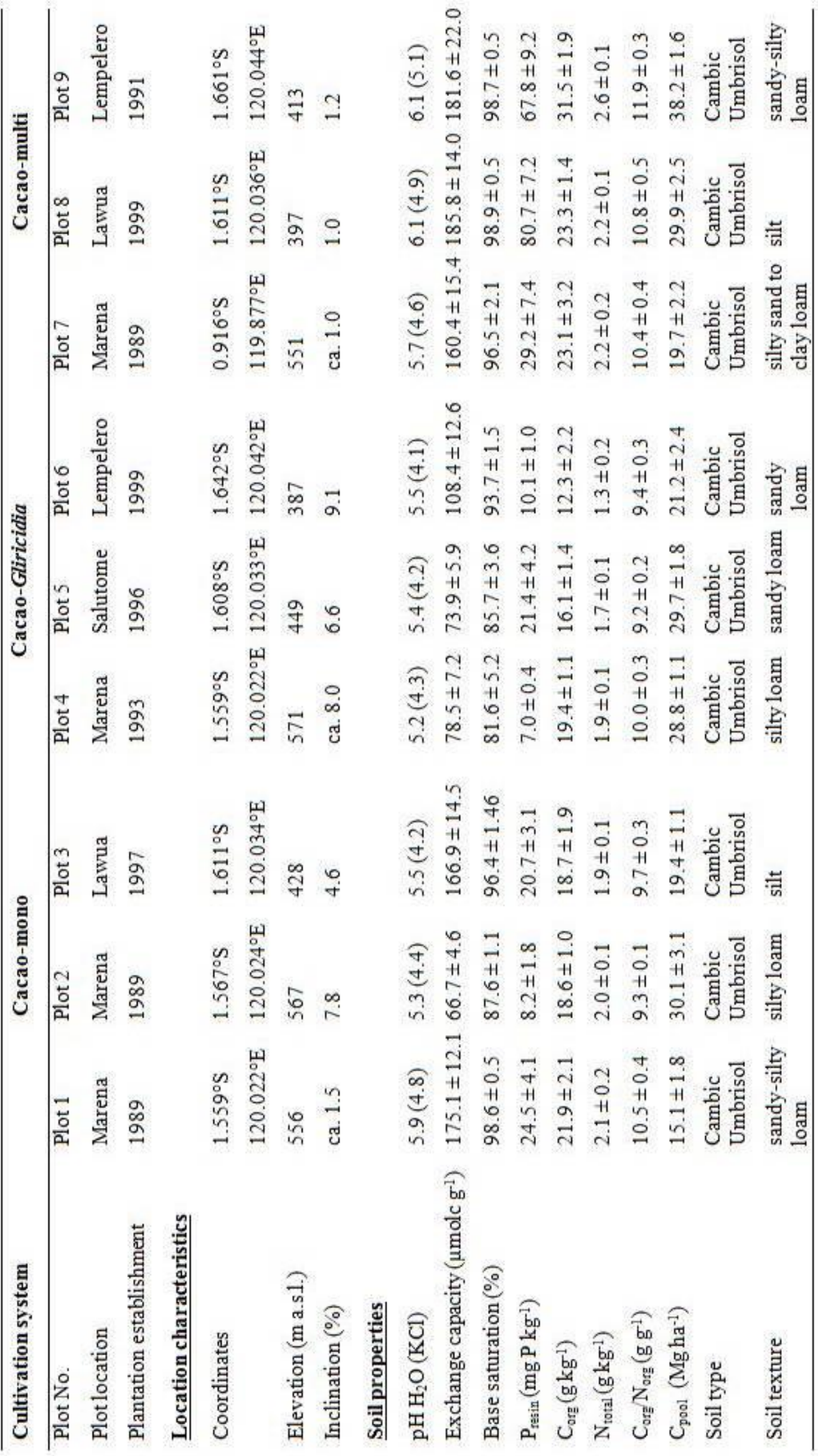




\section{Aboveground stand structure}

A stand inventory was conducted in all nine plots at the beginning of the study in summer 2011. Tree height was determined using an ultrasonic Vertex III height meter (Haglöf, Langsele, Sweden) and stem diameter at breast height (dbh, at $130 \mathrm{~cm}$ ) was measured using a measuring tape. In cases of some cacao and Gliricidia trees, where the stem branched before $130 \mathrm{~cm}$ height, the stem diameter was measured at the next possible height. Subsequently, the diameter was extrapolated to $1.3 \mathrm{~m}$ using species-specific linear allometric regressions between height and diameter, which were obtained by measuring the stem diameter of 10 trees per species in height-intervals of $10 \mathrm{~cm}$.

The diversity of woody species in the plots was quantified with Shannon-Wiener's H' (see equation \#1):

$$
\text { (1) } \mathrm{H}=-\sum\left(\mathrm{p}_{\mathrm{i}} \mathrm{x} \log \mathrm{p}_{\mathrm{i}}\right) \text {, }
$$

with $\mathrm{H}$ being the diversity index, $\mathrm{p}_{\mathrm{i}}$ representing the relative abundance of species $\mathrm{i}\left(\mathrm{p}_{\mathrm{i}}=\right.$ $\left.\mathrm{n}_{\mathrm{i}} / \mathrm{N}\right), \mathrm{n}_{\mathrm{i}}$ the number of individuals per species $\mathrm{i}$, and $\mathrm{N}$ the total number of species per study plot.

\section{Aboveground biomass (AGB) and belowground biomass (BGB)}

The AGB of cacao trees was calculated using the allometric equation of Beer et al. (1990, see equation \#2). For the AGB estimation of Gliricidia sepium and all other shade tree species we used the allometric equation of Chave et al. (2005) for tropical moist forest trees (equation \#3). The AGB of one single coconut palm individual (Cocos nucifera L.) in the plots was calculated after Hairiah et al. (2001) using equation \#4. For banana (Musa sp.), we used equation \#5 after Van Noordwijk and Mulia (2002):

(2) $\mathrm{AGB}=-0.0376+(0.133 \mathrm{BA})$

(3) $\mathrm{AGB}=\exp \left(2.557+0.940 \ln \left(\rho \mathrm{D}^{2} \mathrm{H}\right)\right)$

(4) $\mathrm{AGB}=\pi \mathrm{D}^{2} \mathrm{H} \rho / 40$

(5) $\mathrm{AGB}=0.03 \mathrm{D}^{2.13}$

with AGB being the estimated aboveground biomass in $\mathrm{kg}$ per tree (including stem, branch wood and leaf biomass), BA stem basal area at breast height (in $\left.\mathrm{cm}^{2}\right)$, D stem diameter at breast height (in $\mathrm{cm}$ ), $\mathrm{H}$ total tree height (in $\mathrm{m}$ ), and $\rho$ wood density (in $\mathrm{g} \mathrm{cm}^{-3}$ ). Wood density values for most of the species were obtained from Kotowska et al. (2015), who measured $\rho$ in the same study plots. In cases of tree species, for which wood density data was not available from this source, we used data from the World Agroforestry Centre (http://db.worldagroforestry.org/wd, January 2014) and from other literature sources (FuentesTalavera et al. 2011 and Baker et al. 2004). In two cases, where no information on wood density from these sources was available, we used the plot average of wood density as an estimate (e.g. Baker et al. 2004, Leuschner et al. 2013, Saj et al. 2013).

The BGB was estimated indirectly from the AGB using equation \#6 after Cairns et al. (1997). 
(6) $\quad \mathrm{BGB}=\exp (-1.0587+0.8836 \ln (\mathrm{AGB}))$

As this equation delivers data on coarse root and root stock biomass, but not on fine root biomass, we added the standing fine root biomass from our own inventory down to $3 \mathrm{~m}$ soil depth to the BGB on each plot (see description below).

To obtain profile totals of standing fine root biomass, root inventory data from the upper soil $(0-60 \mathrm{~cm})$ and from deep soil pits $(0-300 \mathrm{~cm})$ were obtained and combined as follows; For recording the standing fine root mass, twelve randomly selected soil samples were taken at each study site with a soil corer $(3.5 \mathrm{~cm}$ in diameter) down to a depth of $60 \mathrm{~cm}$.

In the laboratory, the root samples were soaked in water and cleaned of soil residues using a sieve with a mesh size of $1 \mathrm{~mm}$. Large root fractions (>10 $\mathrm{mm}$ in length) were picked out by hand. Living and dead rootlets were distinguished under the stereomicroscope by color, root elasticity, and the degree of cohesion of cortex, periderm, and stele following the method of Leuschner et al. (2001). For half of the samples, an additional, more detailed analysis of small fine root particles ( $<10 \mathrm{~mm}$ in length) was conducted applying a method introduced by Van Praag et al. (1988) and modified by Hertel and Leuschner (2002). The mass of small rootlets was extrapolated to the entire sample by a regression analysis of small rootlets to large rootlets. Alternatively, a mean ratio of small to large root fractions was used if not enough data for performing a regression analysis was available.

In order to analyze the standing fine root biomass also in the subsoil to $300 \mathrm{~cm}$ depth, soil pits were excavated at each study site. In the cacao monoculture systems, each two soil pits ca. $80 \mathrm{~cm}$ distant to randomly selected cacao trees were excavated. In case of the shaded cacao agroforests, two soil pits each for two cacao trees and two shade trees were excavated (i.e. average half way between the stems). Root biomass was recorded by extracting soil monoliths of $30 \mathrm{~cm} \times 30 \mathrm{~cm} \times 20 \mathrm{~cm}$ size $(1 \times \mathrm{w} \times \mathrm{d})$ down to $120 \mathrm{~cm}$ in the soil profile, and of $30 \mathrm{~cm} \times 30 \mathrm{~cm} \times 40 \mathrm{~cm}$ in the $120-300 \mathrm{~cm}$ layer, respectively. The roots were separated by species and into fine roots (roots $<2 \mathrm{~mm}$ in diameter), large roots $(2-5 \mathrm{~mm}$ in diameter), and coarse roots ( $>5 \mathrm{~mm}$ in diameter).

In plot \#6, the deep soil pits could only be excavated to a depth of $100 \mathrm{~cm}$ due to standing water in the pits after heavy rainfall. In this case, we used the mean fine root biomass values for 100-300 cm depth from the other two plots of this cultivation system (plots \# $4+5$ ) to calculate the profile total of fine root biomass.

Roots of grasses and herbs were easily distinguishable from tree fine roots by their smaller diameter, lighter color and the absence of a lignified periderm, but these roots were ignored as the proportion of herb and grass root mass was below 5\% in all plots. In some of the study plots, roots of trees growing outside the plots or belonging to dead tree stumps of the cut shade trees were found. In most cases, this fraction did not exceed 5\%, except for plot \#1 (40\%), plot \#2 (11\%) and plot \#5 (10\%). In the analysis of standing fine root biomass, these root fractions were included. 


\section{Above- and belowground net primary production (NPP)}

Annual above- and belowground NPP was quantified based on the measurement of annual cacao bean yield and total cacao fruit production, annual aboveground woody growth, litter production, and fine and coarse root and root stock biomass production.

For analyzing cacao bean yield and total cacao fruit production (beans and pods), we used data from each 20 cacao trees in the cacao monocultures and from each 10 cacao trees in the shaded agroforest systems that were harvested in a manner as done by the local farmers. In this way, ripe cacao pods were cut every two weeks over a 12-month period and the fresh weight measured directly in the field. For obtaining dry bean weight and dry pod weight, 10 representative pods per study plot were selected in all size classes to determine the ratio of whole fruit fresh weight to dry bean weight and dry pod weight in every plot. To do so, fresh pods were weighed, all fruit components (skin, seeds and fruit pulp) dried separately $\left(70^{\circ} \mathrm{C}\right.$, 72h) and their dry weight determined in the laboratory of the Tadulako University in Palu.

Aboveground woody biomass production was calculated from stem increment data obtained by repeated reading of manual dendrometer tapes (UMS, Munich, Germany) that were installed at breast height during a 12-month period on each 20 tree individuals per study plot. In the shaded cacao systems, each 10 cacao and 10 shade trees were mounted. To calculate the mean annual wood production of the 20 tree individuals of a plot, the diameter increment was applied to the allometric biomass equations given above. The calculated annual wood production rates per tree were extrapolated to all other tree individuals of the respective species or family in a plot. For two tree individuals of species not included in the dendrometer study, we applied plot means of annual basal area increment rate. The few coconut and banana trees were ignored because they do not show secondary stem diameter growth and we lack data on aboveground biomass production.

In order to measure annual leaf and fine litter production, 10 litter traps (size approximately $75 \mathrm{~cm}$ x $75 \mathrm{~cm}$ ) per study site were installed. The litter was collected monthly and sorted at species level into leaves and other fine litter fractions (i.e. flowers, fruits and small twigs). The litter fractions were dried for $72 \mathrm{~h}$ at $70^{\circ} \mathrm{C}$ and weighed in the laboratory in Palu. The litter of trees not growing inside the plot area was added to cacao trees in case of monocultures or to the shade trees in case of shaded cacao cultivation systems, assuming that approximately the same amount of litter should move into the plot by wind as is carried out in the considered time interval. Assuming that monthly leaf and fine litter fall equals monthly leaf and fine litter production, we took the annual litter mass in the plots as litter production (Leuschner et al. 2013). Here, only the data for leaves of cacao and shade trees and the remaining litter components not sorted by species are shown, because leaves of cacao and shade trees made up the largest part of the litter mass in the study sites. Traditionally, all cacao trees are pruned regularly. During the study period farmers left out pruning to avoid differences between the study sites, except of one single pruning event at the end of the study phase, where all farmers pruned at the same time. Unfortunately, the mass of cut twigs and 
leaves at this event could not be recorded, but this should not have had notable effects on our data.

Fine root production was estimated in the different cultivation systems by conducting an ingrowth core experiment with local soil material according to the methodology described by Persson (1980), and Hertel and Leuschner (2002). At 10 randomly chosen locations in each of the nine stands, soil cores were taken $(3.5 \mathrm{~cm}$ in diameter) from the first $30 \mathrm{~cm}$ of the soil. All macroscopically visible live and dead root material was extracted by hand in the field. The remaining soil material was replaced into the hole and the location marked with plastic tubes. Care was taken that the structure and density of the soil in the cores was conserved as much as possible. The samples were recollected with the same soil corer after 10 months, and the extracted core sliced into the soil layers $0-10$ and $10-30 \mathrm{~cm}$ depth. In the laboratory of the Tadulako University of Palu, root biomass was extracted as described above. Following Vogt et al. (1998) and Hertel and Leuschner (2002), we calculated fine root production in the cores as the increase in root biomass from the start of root recolonisation (in our study 1 month after installation) until harvest. Fine root growth in the cores during the recolonisation period was extrapolated to 1 year and expressed in $\mathrm{g} \mathrm{m}^{-2} \mathrm{yr}^{-1}$.

The production of coarse root and root stock biomass was calculated from the increase in aboveground woody biomass from the beginning to the end of the study using the allometric equation after Cairns et al. (1997) (see above). The difference was taken as annual coarse root and root stock biomass production.

\section{Carbon pools in biomass and production}

All above- and belowground biomass and production values were converted into carbon stored in plant biomass. The calculation was done based on the $\mathrm{C}$ concentration detected in the different plant fractions. Samples of stem wood, fine roots (diameter $<2 \mathrm{~mm}$ ), coarse roots (diameter $>2 \mathrm{~mm}$ ) and the different litter fractions were analyzed in a $\mathrm{CN}$ auto-analyzer (Vario EL III, Hanau, Germany) at the University of Göttingen, Germany. Only for the C stock present in the cacao bean yield, we used carbon content data from literature (Smiley and Kroschel 2010). The carbon pool of the whole cacao pods was calculated by summing up the carbon stock of the cacao bean seeds from literature and the carbon stock available in the cacao pods without seeds taken from the litter traps. Cacao pods that fell into the litter traps were still too small to contain seeds.

\section{Statistical analyses}

All data were tested for Gaussian distribution using a Shapiro-Wilk test. The majority of the datasets showed a non-Gaussian distribution and could not satisfyingly be transformed. Thus, differences between the cultivation systems were analyzed for all parameters using nonparametric analyses of variance (Kruskal-Wallis test) and a subsequent Mann-Whitney twosample test (Wilcoxon U-test). These calculations as well as Pearson correlation analyses were done with the software package SAS 9.3 (version 9.3, SAS Institute, Cary, NC, USA). Regression analyses were conducted with the software package SigmaPlot (version 11.0, 
Systat Software Inc.). For analyzing interrelations between tree species diversity, stand structure, carbon sequestration and cacao bean yield, we conducted a Principle Components Analysis (PCA) with the package CANOCO, version 4.5 (Biometris, Wageningen, The Netherlands).

\subsection{Results}

\section{Aboveground stand structure}

The Shannon diversity index H' increased from 0 to 0.4 in the sequence cacao monocultures Cacao-Gliricidia systems - Cacao-multi shade-tree systems (Table 2.2). In parallel, canopy cover increased from 50 to $93 \%$, total tree density from 900 to $1700 \mathrm{ha}^{-1}$, and stand basal area from 12.6 to $34.6 \mathrm{~m}^{2} \mathrm{ha}^{-1}$. The Gliricidia shade trees were 3-4 meters taller than the cacao trees; in the multi shade-tree systems, several shade tree species were even taller than the Gliricidia trees and had much larger stem diameters. Total stand basal area was nearly three times larger in the multi shade-tree systems than in the cacao monocultures, while the total number of shade trees was smaller than in the Gliricidia systems (Table 2.2). Stem density of cacao was 30-40 \% higher in the two shaded systems than in the cacao monocultures (2370 and 2540 vs. $1800 \mathrm{ha}^{-1}$, respectively). 


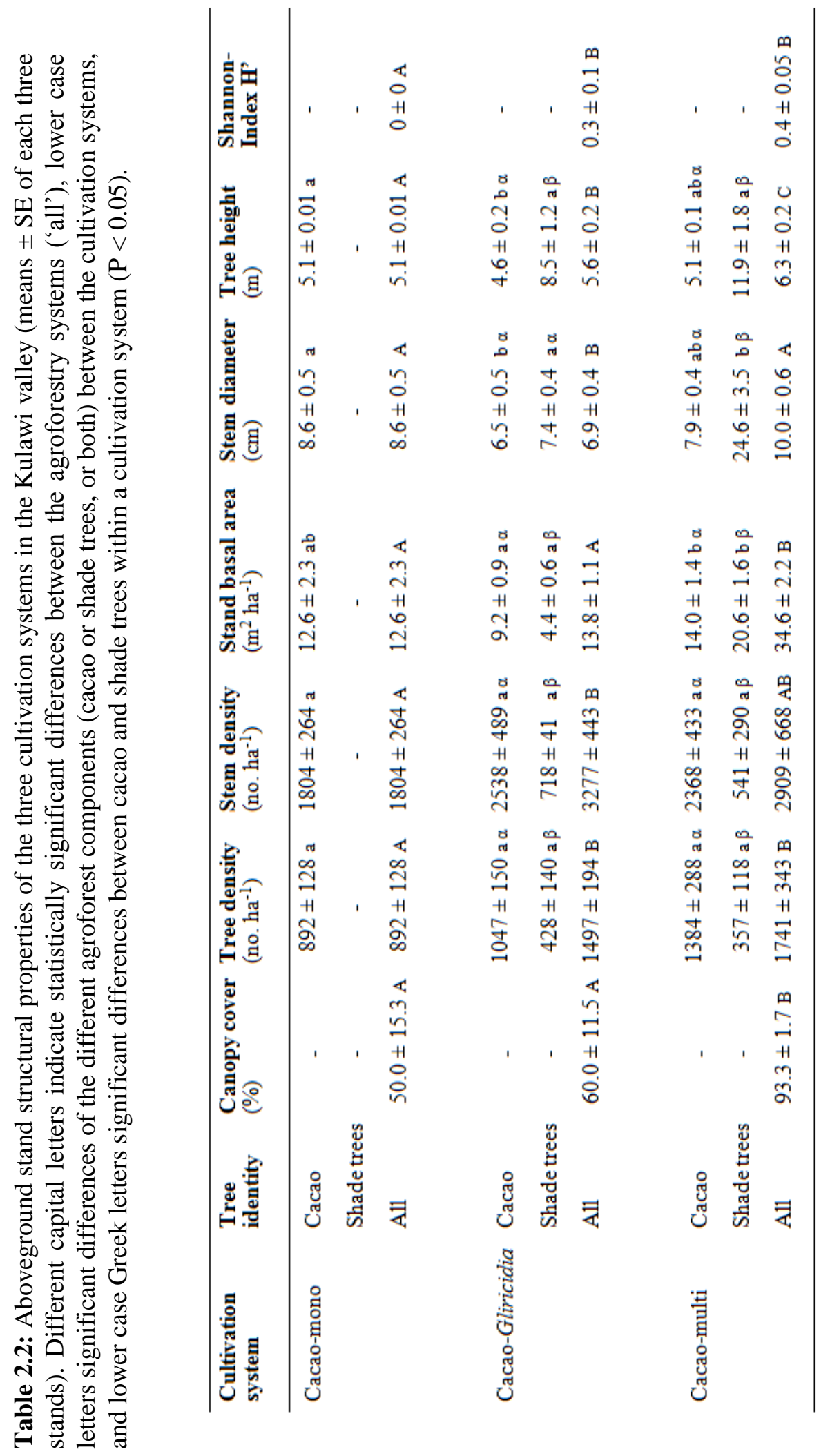


Aboveground and belowground biomass and related $C$ pools

Total aboveground biomass increased more than fivefold from $\sim 17 \mathrm{Mg} \mathrm{ha}^{-1}$ in the monocultures to $30 \mathrm{Mg} \mathrm{ha}^{-1}$ in the Cacao-Gliricidia plantations and to $100 \mathrm{Mg} \mathrm{ha}^{-1}$ in Cacaomulti systems (Figure 2.2). Total belowground biomass including the standing fine root biomass in the $0-300 \mathrm{~cm}$ soil profile showed a similar increase from $6.4 \mathrm{Mg} \mathrm{ha}^{-1}$ in the monocultures to $10.5 \mathrm{Mg} \mathrm{ha}^{-1}$ in Cacao-Gliricidia systems and to $22.9 \mathrm{Mg} \mathrm{ha}^{-1}$ in the multi shaded tree systems. The biomass and carbon contributed by the cacao trees was somewhat lower in the Cacao-Gliricidia stands than in the other two cultivation systems (Figure 2.2 and Table 2.3). Total biomass carbon was nearly six times larger in the multi shade-tree systems than in the monocultures.

Figure 2.2: Above- and belowground biomass, including standing fine root biomass of the three different cacao cultivation systems. Different capital letters indicate statistically significant differences between the agroforestry systems, lower case letters significant differences of the different tree groups between the cultivation systems and lower case Greek letter significant differences between cacao and shade trees within a cultivation system $(P<0.05)$.

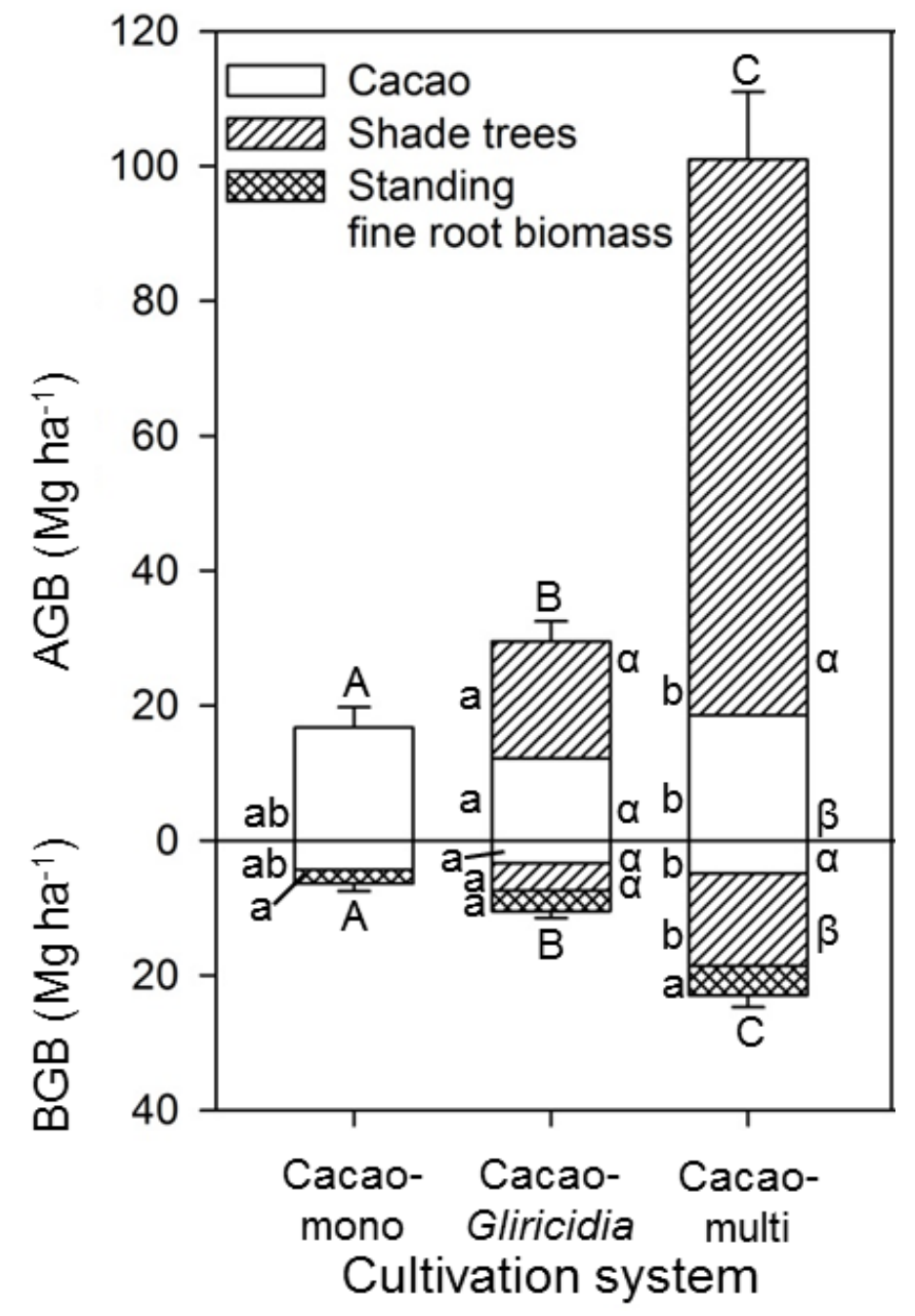


Table 2.3: Above- and belowground carbon stocks and the shoot:root carbon ratio (means \pm SE). Only for the tree group 'all' fine root data is included. Given are means and standard errors. Different capital letters indicate statistically significant differences between the agroforestry systems, lower case letters indicate statistically significant differences of the different tree groups between the cultivation systems and lower case Greek letter indicate statistically significant differences between cacao and shade trees within a cultivation system $(P<0.05)$.

\begin{tabular}{|c|c|c|c|c|c|}
\hline $\begin{array}{l}\text { Cultivation } \\
\text { system }\end{array}$ & $\begin{array}{l}\text { Tree } \\
\text { identity }\end{array}$ & $\begin{array}{l}\text { Aboveground } \\
\text { carbon stock } \\
\left(\mathrm{Mg} \mathrm{ha}^{-1}\right)\end{array}$ & $\begin{array}{l}\text { Belowground } \\
\text { carbon stock } \\
\left(\mathrm{Mg} \mathrm{ha}^{-1}\right)\end{array}$ & $\begin{array}{l}\text { Total } \\
\text { carbon stock } \\
\left(\mathrm{Mg} \mathrm{ha}^{-1}\right)\end{array}$ & $\begin{array}{c}\text { Shoot:root } \\
\text { ratio }\end{array}$ \\
\hline Cacao-mono & $\begin{array}{l}\text { Cacao } \\
\text { Shade trees } \\
\text { All }\end{array}$ & $\begin{array}{l}7.7 \pm 1.4 \mathrm{ab} \\
\text { n.a. } \\
7.7 \pm 1.4 \mathrm{~A}\end{array}$ & $\begin{array}{l}1.9 \pm 0.4 \mathrm{a} \\
\text { n.a. } \\
2.8 \pm 0.5 \mathrm{~A}\end{array}$ & $\begin{array}{l}9.7 \pm 1.8 \mathrm{ab} \\
\text { n.a. } \\
10.6 \pm 1.9 \mathrm{~A}\end{array}$ & $\begin{array}{l}4.1 \pm 0.1 \mathrm{a} \\
\text { n.a. } \\
2.8 \pm 0.3 \mathrm{~A}\end{array}$ \\
\hline Cacao-Gliricidia & $\begin{array}{l}\text { Cacao } \\
\text { Shade trees } \\
\text { All }\end{array}$ & $\begin{array}{r}5.6 \pm 0.6 \mathrm{a} \alpha \\
8.4 \pm 0.9 \mathrm{a} \beta \\
14.0 \pm 1.4 \mathrm{~B}\end{array}$ & $\begin{array}{l}1.5 \pm 0.1 \mathrm{a} \alpha \\
1.6 \pm 0.1 \mathrm{a} \alpha \\
4.4 \pm 0.4 \mathrm{~B}\end{array}$ & $\begin{array}{r}7.1 \pm 0.7 \text { a } \alpha \\
10.5 \pm 0.8 \text { a } \beta \\
18.4 \pm 1.8 \mathrm{~B}\end{array}$ & $\begin{array}{l}3.7 \pm 0.1 \mathrm{~b} \alpha \\
4.2 \pm 0.8 \mathrm{a} \alpha \\
3.2 \pm 0.1 \mathrm{~A}\end{array}$ \\
\hline Cacao-multi & $\begin{array}{l}\text { Cacao } \\
\text { Shade trees } \\
\text { All }\end{array}$ & $\begin{array}{r}8.6 \pm 0.8 \mathrm{~b} \alpha \\
39.0 \pm 5.4 \mathrm{~b} \beta \\
47.6 \pm 4.8 \mathrm{C}\end{array}$ & $\begin{array}{l}2.1 \pm 0.2 \mathrm{a} \alpha \\
5.9 \pm 0.5 \mathrm{~b} \beta \\
9.8 \pm 0.7 \mathrm{C}\end{array}$ & $\begin{array}{l}10.2 \pm 0.7 \mathrm{~b} \alpha \\
44.9 \pm 5.9 \mathrm{~b} \beta \\
57.4 \pm 5.5 \mathrm{C}\end{array}$ & $\begin{array}{l}5.3 \pm 0.8 \mathrm{ab} \alpha \\
6.6 \pm 0.4 \mathrm{~b} \quad \alpha \\
4.9 \pm 0.1 \mathrm{~B}\end{array}$ \\
\hline
\end{tabular}

Standing fine root biomass $(0-300 \mathrm{~cm}$ profile) increased although not significantly with increasing shade tree cover in the three systems $\left(206,301\right.$ and $432 \mathrm{~g} \mathrm{~m}^{-2}$, respectively) with more than two times larger totals in the Cacao-multi plots than in the monocultures (data not shown). The biomass increase was greater in the aboveground than the belowground compartment, leading to a shoot : root ratio increase from 2.8 to 4.9 from the monocultures to the diverse multi shade-tree systems (Table 2.3).

\section{Net primary production and its components}

Total (above- and belowground) net primary production nearly doubled from the monocultures to the multi shade-tree systems $\left(19.5,28.2\right.$ and $37.7 \mathrm{Mg} \mathrm{ha}^{-1} \mathrm{yr}^{-1}$ in the three systems, equaling 9.1, 13.4 and 17.7 $\mathrm{Mg} \mathrm{C} \mathrm{ha}^{-1} \mathrm{yr}^{-1}$; Figure 2.3 and Table 2.4). The increase was mainly driven by the much larger wood and coarse root production of the shaded systems than of the cacao monocultures, while the increase in litter production from the monocultures to the multi shade-tree systems was only moderate (5.3 to $9.7 \mathrm{Mg} \mathrm{ha}^{-1} \mathrm{yr}^{-1}$ ); fine root production remained unchanged $\left(1.7,1.5\right.$ and $\left.1.9 \mathrm{Mg} \mathrm{ha}^{-1} \mathrm{yr}^{-1}\right)$. The total biomass production of cacao showed a slight but non-significant decrease from the monocultures $\left(19.5 \mathrm{Mg} \mathrm{ha}^{-1} \mathrm{yr}^{-}\right.$ ${ }^{1}$ ) to the multi shade-tree systems (15.7 $\left.\mathrm{Mg} \mathrm{ha}^{-1} \mathrm{yr}^{-1}\right)$. Similarly, cacao fruit production (beans and pods) tended to be somewhat lower in the latter systems (8.3 vs. $9.7 \mathrm{Mg} \mathrm{ha}^{-1} \mathrm{yr}^{-1}$ ) while bean production was remarkably invariant across the three cultivation systems $(2.0-2.1 \mathrm{Mg}$ $\mathrm{ha}^{-1} \mathrm{yr}^{-1}$; Table 2.4). The litter production of cacao was much higher in the monocultures (5.3 $\left.\mathrm{Mg} \mathrm{ha}^{-1} \mathrm{yr}^{-1}\right)$ than in the two shaded systems $\left(2.9 \mathrm{Mg} \mathrm{ha}^{-1} \mathrm{yr}^{-1}\right)$. When calculated per cacao 
tree individual, been yield decreased from 2.4 to 2.0 and $1.6 \mathrm{Mg} \mathrm{ha}^{-1} \mathrm{yr}^{-1}$ from the monocultures to the Gliricidia shade system and to the multi shade-tree system (differences not significant), but this tendency was compensated by the higher cacao stem density on the plot level in the latter.

Figure 2.3: Above- and belowground carbon production of the three different cacao cultivation systems. Different capital letters indicate statistically significant differences between the agroforestry systems, lower case letters significant differences of the different tree groups between the cultivation systems and lower case Greek letter significant differences between cacao and shade trees within a cultivation system $(\mathrm{P}<0.05)$.

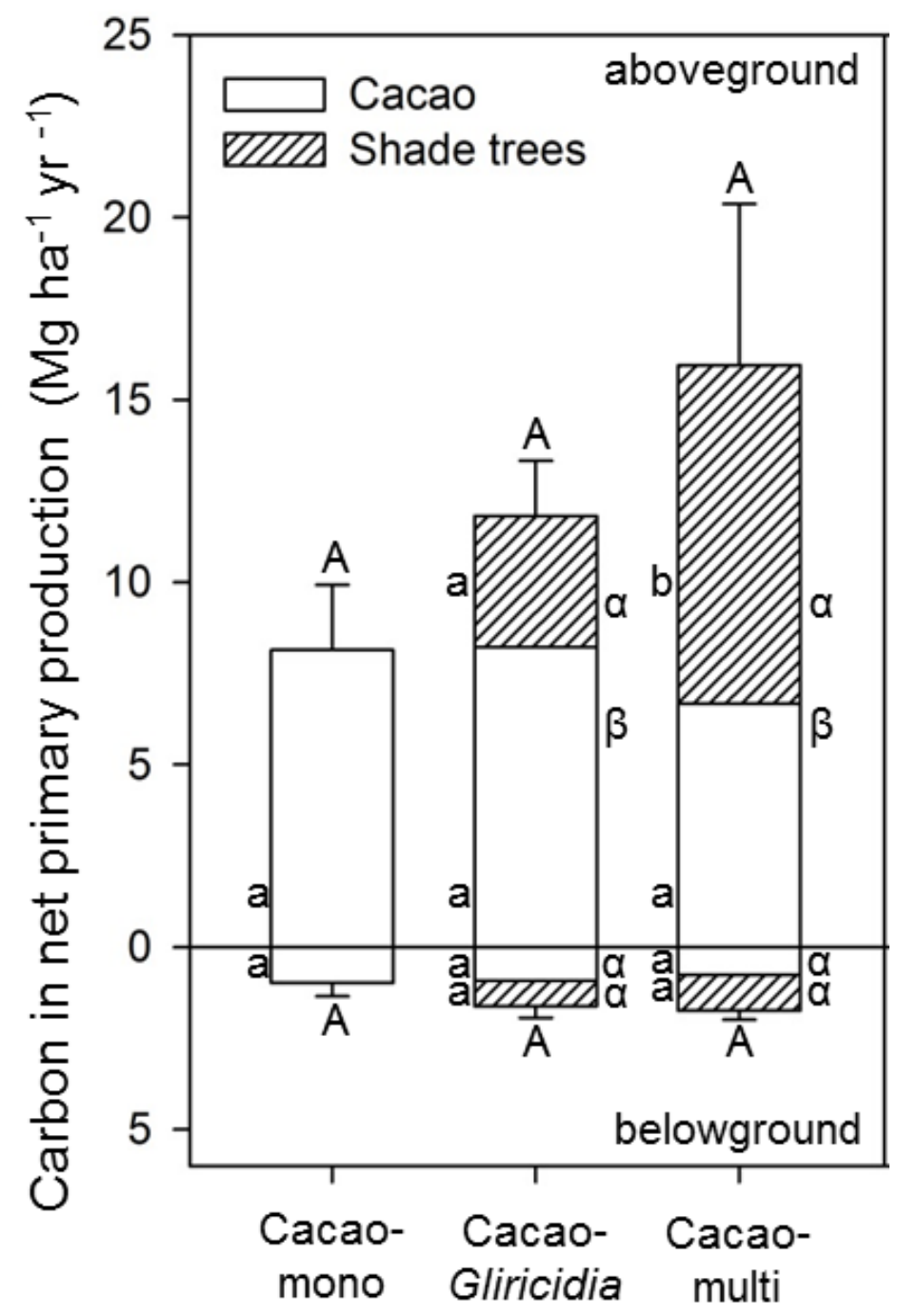

Cultivation system 


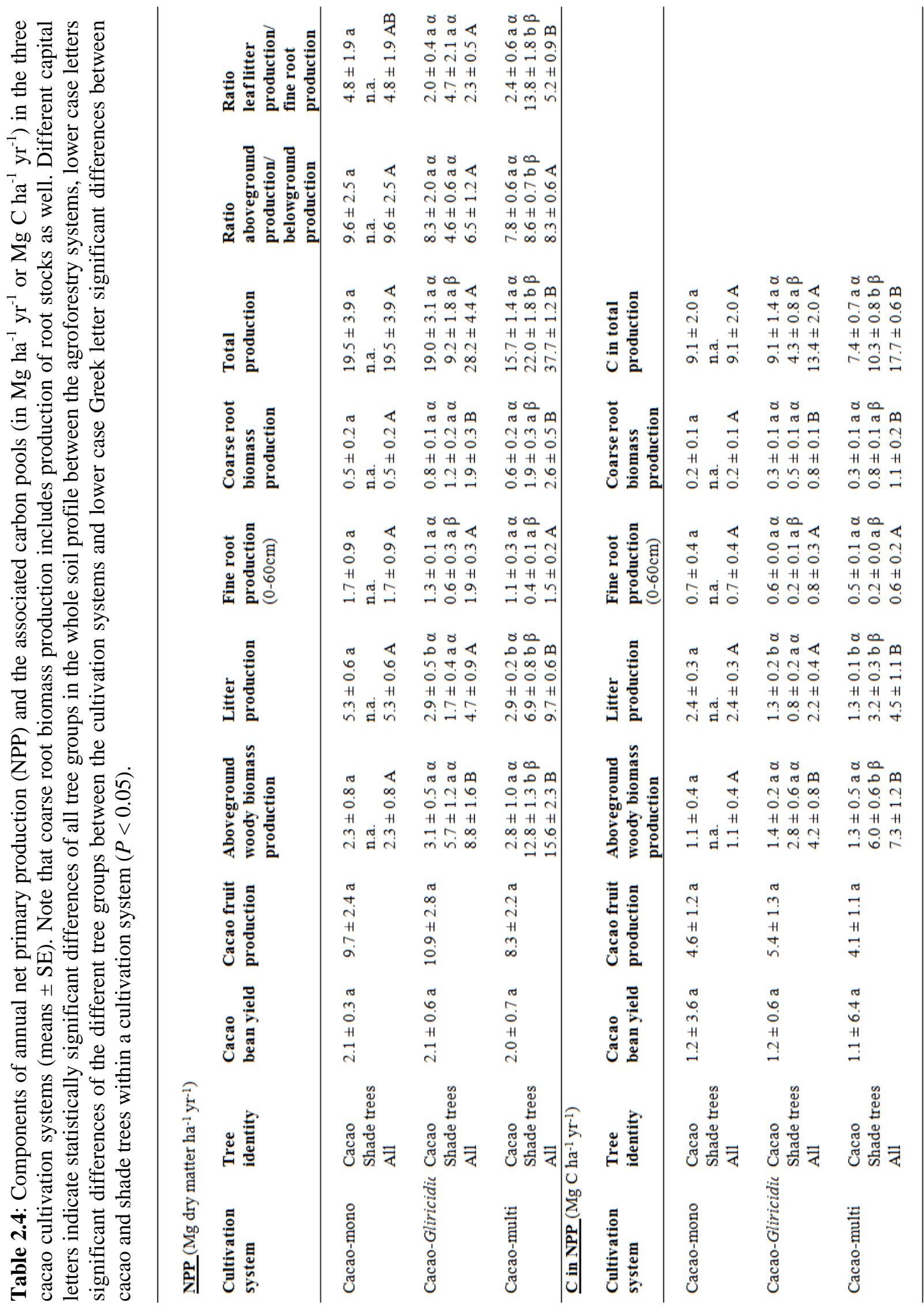


In the Cacao-mono and the Cacao-Gliricidia systems, leaf litter made up 91 and $90 \%$ of the total aboveground litter production, respectively, while in the Cacao-multi shade-tree systems, $21 \%$ of aboveground litter referred to other components (flowers, fruits, twigs, Figure 2.4). While total fine root production did not differ between the three cultivation systems, the fine root productivity of cacao tended to decrease from monocultural to multi shade-tree systems despite increasing cacao stem density (Table 2.4; difference not significant). Unexpected is that the fine root production of cacao trees was larger than that of shade trees in both shaded systems despite higher aboveground productivity of the latter, although this effect was not significant.

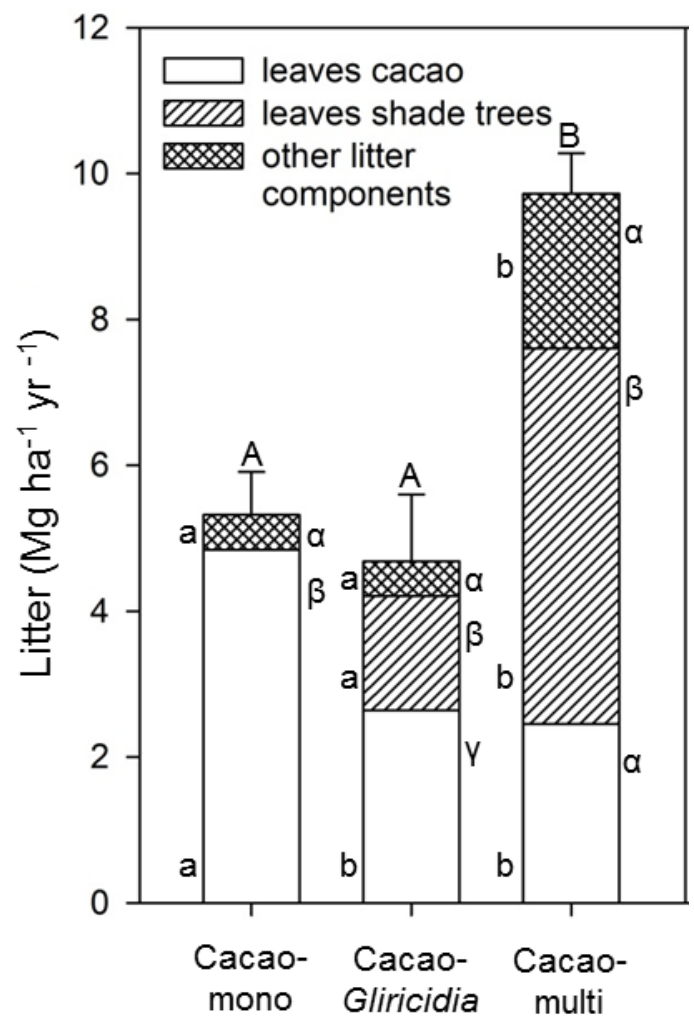

Figure 2.4: Litter production of the different cacao agroforests. Shown are leaf litter of cacao and shade trees and the remaining litter components per cultivation system. Different capital letters indicate statistically significant differences between the agroforestry systems, lower case letters significant differences of the different tree groups between the cultivation systems and lower case Greek letter significant differences between cacao and shade trees within a cultivation system $(P<0.05)$.

Cultivation system

The ratio of above- to belowground NPP was highest in the cacao monocultures, followed by the Cacao-multi systems and lowest in the Cacao-Gliricidia stands (Table 2.4). However, while the above- to belowground NPP ratio tended to decrease for cacao trees with increasing shade tree diversity, this ratio increased in the same direction for the shade trees (only partly significant at $\mathrm{p}<0.05)$.

Interrelations between shade tree diversity, stand structure, productivity, and cacao bean yield

A Principal Components Analysis on the inter-relationships between cacao bean yield, C storage in biomass, aboveground, belowground and total NPP, as well as aboveground stand structural properties and tree species diversity (Shannon index) in the nine stands revealed a close association of the tested biomass and productivity parameters with tree density, basal 
area, canopy cover and also canopy layer diversity $\left(\mathrm{H}^{\prime}\right)$, but not with cacao bean yield (Table 2.5). Cacao bean yield showed a close (negative) association with axis 2 (eigenvalue 0.184) but was relatively independent from the other tested biomass and productivity parameters.

Table 2.5: Results of a PCA analysis based on the plots of the three studied cacao cultivation systems and their corresponding data on cacao bean yield, carbon stores, stand structural data and diversity. Given are the eigenvalues (EV) of the four main axes and the loading of nine parameters on these. The values in brackets give the fraction of variance explained by the variable. The most important factors on each axis are printed bold.

\begin{tabular}{|c|c|c|c|c|}
\hline Variables & $\begin{array}{c}\text { Axis 1 } \\
(\mathrm{EV} 0.6224)\end{array}$ & $\begin{array}{c}\text { Axis } 2 \\
(\mathrm{EV} 0.1495)\end{array}$ & $\begin{array}{c}\text { Axis } 3 \\
(\mathrm{EV} 0.0913)\end{array}$ & $\begin{array}{c}\text { Axis } 4 \\
(\mathrm{EV} 0.0612)\end{array}$ \\
\hline Cacao bean yield & $-0.100(0.01)$ & $-0.911(0.87)$ & $0.174(0.05)$ & $0.121(0.05)$ \\
\hline $\mathrm{C}$ in aboveground NPP & $-0.907(0.82)$ & $-0.430(0.11)$ & $-0.152(0.02)$ & $0.003(0.00)$ \\
\hline $\mathrm{C}$ in belowground NPP & $-0.690(0.48)$ & $-0.435(0.00)$ & $-0.228(0.38)$ & $-0.056(0.00)$ \\
\hline $\mathrm{C}$ in total NPP & $-0.915(0.84)$ & $-0.178(0.09)$ & $0.031(0.04)$ & $-0.336(0.00)$ \\
\hline $\mathrm{C}$ in total biomass & $-0.894(0.80)$ & $0.148(0.00)$ & $0.445(0.06)$ & $-0.094(0.13)$ \\
\hline Tree density & $-0.758(0.57)$ & $0.195(0.07)$ & $-0.535(0.00)$ & $0.168(0.31)$ \\
\hline Stand basal area & $-0.907(0.82)$ & $0.177(0.00)$ & $0.273(0.06)$ & $0.139(0.02)$ \\
\hline Canopy cover & $-0.787(0.62)$ & $0.290(0.05)$ & $0.102(0.20)$ & $0.458(0.03)$ \\
\hline Shannon-Index & $-0.801(0.64)$ & $0.492(0.15)$ & $-0.081(0.01)$ & $-0.302(0.00)$ \\
\hline
\end{tabular}

Bivariate Pearson correlation analyses showed that all biomass and productivity parameters were significantly related to tree diversity in the canopy of the cacao cultivation systems except for bean yield, litter production and fine root production; the latter varied independently from the number of shade tree species present (Table 2.6).

Table 2.6: Pearson correlation coefficients of linear regressions between species diversity (Shannon Index) and yield and above- and belowground carbon stocks from biomass and net primary production (NPP).

\begin{tabular}{llcr}
\hline Parameter & Source & $\begin{array}{l}\text { Correlation } \\
\text { coefficient }\end{array}$ & P \\
\hline \multirow{2}{*}{ Shannon-Index } & Cacao bean yield & -0.26 & 0.51 \\
& C in aboveground woody biomass production & 0.77 & $<\mathbf{0 . 0 5}$ \\
& C in litter production & 0.57 & 0.11 \\
& C in fine root production $(0-60 \mathrm{~cm})$ & -0.16 & 0.68 \\
& C in coarse root biomass production & 0.72 & $<\mathbf{0 . 0 5}$ \\
& C in total NPP & 0.66 & $<\mathbf{0 . 0 5}$ \\
Shannon-Index & C in aboveground biomass & 0.70 & $<\mathbf{0 . 0 5}$ \\
& C in belowground biomass & 0.73 & $<\mathbf{0 . 0 5}$ \\
& C in total biomass & 0.70 & $<\mathbf{0 . 0 5}$ \\
\hline
\end{tabular}




\subsection{Discussion}

Shade tree effects on biomass, carbon stores and productivity

Total above- and belowground carbon in biomass was five times larger in the multi-shade tree systems than in cacao monoculture. With 11,18 and $57 \mathrm{Mg} \mathrm{C} \mathrm{ha}^{-1}$ in monoculture, CacaoGliricidia and multi-shade tree system, respectively, the measured carbon stocks were well within the range of values reported for cacao agroforests in other tropical regions (e.g. Montagnini and Nair 2004, Nair et al. 2010, Somarriba et al. 2013). Shade trees contributed 57 and 78 percent of the total biomass carbon (above- and belowground) in the Gliricidia and the multi-species cultivation system, respectively. Clearly, the $57 \mathrm{Mg} \mathrm{C}^{-1}$ are only about one third of the biomass $\mathrm{C}$ which is stored in a natural tropical forest in the region $(\sim 150 \mathrm{Mg}$ $\mathrm{C} \mathrm{ha}^{-1}$, Leuschner et al. 2013). Considering soil carbon stocks as well, these losses are even higher as Kessler et al. (2012) reported a total above- and belowground carbon stock of 284 $\mathrm{Mg} \mathrm{C} \mathrm{ha}{ }^{-1}$ in natural forest plots in Sulawesi. Although the soil organic carbon content from 0-60 $\mathrm{cm}$ increased from $22 \mathrm{Mg} \mathrm{ha}^{-1}$ to $27 \mathrm{Mg} \mathrm{ha}^{-1}$ and $29 \mathrm{Mg} \mathrm{ha}^{-1}$ in the Cacao-mono, CacaoGliricidia and Cacao-multi systems, respectively (data not shown), we could not find significant differences. Even though carbon fixation of the whole system is much lower in diverse cacao agroforests than in primary forests, nevertheless it is greater than in perennial monocultures or annual crops (e.g. Rice and Greenberg 2000, Duguma et al. 2001, Schroth et al. 2002). The huge contribution of shade trees to biomass, carbon and annual carbon sequestration both above- and belowground stresses the importance of the role of shade trees in agroforestry ecosystems in our study.

The increasing canopy cover from $50 \%$ to $93 \%$ from the monocultural to the multispecies system was associated with a 6 fold increase in aboveground biomass but only a 3.5 fold increase in root biomass resulting in nearly a doubling of the shoot:root biomass ratio (2.8 to 4.9). A significant positive interrelation between tree species richness and both, carbon stocks in above- and belowground biomass, and in annual carbon sequestration via NPP could be proven. Nevertheless, fine root biomass in the $300 \mathrm{~cm}$ deep profile was more than doubled in this sequence of increasing shade tree diversity (206 to $432 \mathrm{~g} \mathrm{~m}^{-2}$ ), which must have increased the intensity of root competition. However, the differences in total aboveground biomass increase also suggest that the planting of tall-growing shade trees should lead to fiercer competition between cacao and shade trees for light rather than for water and nutrients. Detailed studies of root distribution patterns in Cacao-Gliricidia agroforests in nearby plantations have shown that the root systems of cacao and Gliricidia are vertically stratified with cacao roots concentrating in the upper profile and Gliricidia roots in the subsoil (Moser et al. 2010). Indeed, stable isotope analyses confirmed that these two species showed complementary soil water use in these plantations (Schwendenmann et al. 2010). Another study from Lehmann (2003) revealed that shaded crops like coffee and cacao tend to have shallower root activity than fruit trees and that most of cacao's root activity occurs in the topsoil. A consequence is the complementary use of soil water resources and thus only limited 
competition between cacao and the shade trees (Ong et al. 2004, Ewel and Mazzarino 2008, Moser et al. 2010, Schwendenmann et al. 2010). However, for the more complex rooting patterns in our Cacao-multi systems, corresponding information on complementary root distribution and water partitioning are not available, yet.

Likewise to tree biomass and corresponding $\mathrm{C}$ stocks, carbon sequestration rates were significantly highest in Cacao-multi plots with $18 \mathrm{Mg} \mathrm{ha}^{-1} \mathrm{yr}^{-1}$ compared to the less productive Cacao-Gliricidia and Cacao-mono stands with $13 \mathrm{Mg} \mathrm{ha}^{-1} \mathrm{yr}^{-1}$ and $9 \mathrm{Mg} \mathrm{ha}^{-1} \mathrm{yr}^{-1}$, respectively. The productivity data for cacao trees show that increased shading resulted in preferential allocation of carbon toward aboveground growth and not root growth. Fine root production of cacao tended to decrease (from 0.7 to $0.5 \mathrm{Mg} \mathrm{C} \mathrm{ha}^{-1} \mathrm{yr}^{-1}$ ), coarse root growth slightly rose, and stem and branch wood production tended to increase as well (from 1.1 to $1.3 \mathrm{Mg} \mathrm{C} \mathrm{ha}^{-1}$ $\mathrm{yr}^{-1}$ ) from the monocultures to the multi-shade tree systems. This holds support that the presence of shade trees may not lead to pronounced increasing light competition in the stand as well as it appears that the presence of shade trees do not induce increased belowground competition since fine root production is expected to increase under enhanced belowground competition due to increasing fine root turnover (Hertel et al. 2013). As Theobroma cacao is a $\mathrm{C}_{3}$-plant that is adapted to semi-shade in the forest understory, full sunlight may represent rather a stress factor. Photosynthesis of this species has been found to saturate already at photon flux densities of ca. $400 \mu \mathrm{mol} \mathrm{m} \mathrm{m}^{-2}$ (Balasimha et al. 1997, Baligar et al. 2008), which is equivalent to about $25 \%$ of full sunlight. Our data on aboveground woody biomass production fits well to the results of other studies as enhanced vegetative growth of cacao trees cultivated together with shade trees has also been observed before (Beer et al. 1990, Schroth et al. 2002, Isaac et al. 2007). Köhler et al. (2009) found enhanced water uptake and thus increased cacao stem diameter and leaf area in Gliricidia-shaded cacao plantations in the same study region. In a recent study from Köhler et al. (2014) who investigated sap flux in the same sites, a trend for higher water use of cacao trees grown under shade was reported as well.

Our data show that total NPP of cacao on the plot level decreased, whereas cacao bean yield did not. The productivity reduction occurred from the Cacao-Gliricidia to the Cacaomulti system with a canopy cover increase from 60 to $93 \%$. The stable bean production of approx. $2 \mathrm{Mg} \mathrm{ha}^{-1} \mathrm{yr}^{-1}$ across all three cultivation systems indicates that there is no strong influence of shade intensity on seed production. Our bean yield figures are relatively high compared to other studies (e.g. Wade et al. 2010, Clough et al. 2011), but match results of Ruf et al. (1995) who reported a yield of marketable cacao beans of $2 \mathrm{Mg} \mathrm{ha}^{-1}$ for Sulawesi. In the literature, mixed results exist with respect to cacao bean yield change under increased shade tree cover. While a number of studies found a decrease (Beer et al. 1998, Johns 1999, SteffanDewenter et al. 2007, Bisseleua et al. 2009, Clough et al. 2009, Gockowski and Sonwa 2011, Bisseleua et al. 2013), others reported no negative shade tree effect on yield (Gordon et al. 2006, Perfecto et al. 2007, Perfecto and Vandermeer 2010, Clough et al. 2011, Tscharntke et al. 2012). Clearly, the shade trees' species identity and the intensity of shading must be 
influential. Nevertheless, our data seem to indicate that shading does not impede cacao productivity and yield in a significant way.

On single tree level, total NPP per cacao tree decreased with increasing shade cover from 22 to $13 \mathrm{~kg} \mathrm{tree}^{-1}$ as well as cacao bean yield per tree tended to decrease from 2.4 to $1.6 \mathrm{~kg}$ tree $^{-1}$. However, both trends of decrease per tree were statistically not significant. From an economic perspective the missing effect of increased shade tree cover on cacao bean yield per cultivation system is of much greater relevance than the reduction in cacao NPP. It must not be neglected that the constant cacao bean production is partly a result of the higher cacao tree density in the shaded systems. However, other factors must have additionally contributed to the invariant cacao bean production on the plot level. Although there is a slight decrease in cacao bean yield, it is not as high as expected. Aboveground NPP per cacao tree decreased by $42 \%$ from the Cacao-mono to the Cacao-multi system, while the cacao bean production decreased just by $33 \%$. Therefore, we conclude that there must be beneficial ecosystem services provided by shade trees, allowing the steadily high cacao bean production even under dense shade tree cover.

\section{Beneficial effects of shade trees}

Shade trees may help to reduce the stress exposure of cacao to high evaporative demand and high radiation intensity. Miyaji et al. (1997) found that cacao leaves have shortened leaf longevity and are shed earlier when growing in the upper canopy and thus higher exposition to sunlight. Full light exposure can also lead to stomatal closure resulting from drought stress and consequently reducing photosynthetic activity and thus growth (Balasimha et al. 1991). Such responses might be related to the natural occurrence of cacao in the understory of closed forests. Our data on leaf litter production also fit into this picture. We measured a nearly twofold higher leaf litter production (5.3 vs. $2.9 \mathrm{Mg} \mathrm{ha}^{-1} \mathrm{yr}^{-1}$ ) in the non-shaded than in the shaded systems, indicating shorter leaf longevity and a stress response to drought and high solar radiation. The fact that the monocultures achieved their wood production and total NPP with a much higher leaf production and turnover, must be interpreted as a hint on elevated stress at the foliage level. Thus, strong evidence exists that growing cacao in non-shaded monocultures places the species beyond the range of optimal growing conditions.

In fact, it seems that the removal of shade trees enhances cacao bean yield, if at all, only in the short term (Johns 1999, Rice and Greenberg 2000, Belsky and Siebert 2003, SteffanDewenter et al. 2007, Clough et al. 2009), while it increases physiological stress and may reduce the stability of the system. Several authors argued that cacao agroforests with shade trees may produce lower, but stable yields and thus are more productive in the long-term (Johns 1999, Rice and Greenberg 2000, Belsky and Siebert 2003, Steffan-Dewenter et al. 2007, Clough et al. 2009). Moreover, shade trees seem to increase the productive lifetime of cacao trees (Obiri et al. 2007, Clough et al. 2011) through the reduction of physical stress. In intensified cacao cultivation systems, yield tends to decrease after 15-20 years (Rice and Greenberg 2000). In our cacao plantations, the trees had an age of already 20-30 years. Given 
the relatively high bean yield of $2 \mathrm{Mg} \mathrm{ha}^{-1} \mathrm{yr}^{-1}$, this shows that cacao can remain productive for quite long time spans under a more or less dense canopy of shade trees.

There are also economic reasons for farmers to cultivate cacao under moderate shade cover. Due to pronounced fluctuation of the cocoa price on the world market, farmers should have an interest in a stable production, even at a perhaps somewhat reduced yield, but at lower cost, compared to higher short-term yield with high input and labor costs (e. g. Beer et al. 1998). Moreover, shaded and more complex-structured cacao agroforestry systems provide a number of important ecosystem services that may increase the farmer's revenue and might be able to compensate possible negative effects (e.g. Beer 1987, Ong et al. 1991, Beer et al. 1998, Rice and Greenberg 2000, Bisseleua et al. 2009, Köhler et al. 2014).

A cover of shade trees, especially when it contains more than one tree species, harbors not only a more diverse fauna (Schroth and Harvey 2007, Tscharntke et al. 2011) than cacao monocultures, but it also provides additional non-monetary and monetary goods and services that need consideration when selecting the most appropriate cultivation system. Nutrient input through nitrogen fixation by Gliricidia and other leguminous shade trees present on the shaded plots is likely an important source for nutrition of the Cacao-Gliricidia and the Cacaomulti systems. Further nutrient input and cycling is also provided by enhanced aboveground litter fall and decomposition. Pests and diseases cause huge losses in cacao yield worldwide (Bowers et al. 2001). Diverse plant and animal communities may provide natural pest control through the provision of niches for insectivorous birds, parasitoids and pest-feeding insects (e.g. Klein et al. 2002, Clough et al. 2009, Bisseleua et al. 2009, Philpott et al. 2009, Bisseleua et al. 2013). Wielgoss et al. (2012) could show that cacao yield loss was reduced due to the co-existence of a minor pest, the mirid bug Helopeltis sulawesi, and a major pest, the pod-boring moth Conopomorpha cramerella, in a shaded cacao system. Although another major pest, the black pod disease, which is caused by Phytophthora palmivora, generally tends to increase with increasing humidity (Beer et al. 1998), it may be hold in check by the presence of more endophytic antagonists under a more diverse tree canopy (Arnold et al. 2003, Bos et al. 2007). Our measurements further show that relative air humidity was increased only very slightly with increasing shade tree cover, suggesting that Phythopthora should not profit significantly from the presence of shade trees in our stands and shade trees might act more like a protection from wind dispersal. A layer of shade trees can reduce weed cover under the cacao trees and may minimize soil erosion after heavy rainfall (Rice and Greenberg 2000). Shade trees and the associated entomofauna may also indirectly increase cacao bean yield by enhancing pollination services. This may be of particular relevance for the strictly entomophilous cacao, since pollinator abundance have been found to positively correlate with pod set and thus yield (Young 1985, Groeneveld et al. 2010, Frimpong et al. 2011). While the monetary value of most of these services is not exactly known, Obiri et al. (2007) found highest net cash flow in shaded agroforests, where additional income was generated from the harvest of timber and other merchantable goods, and because labor and input costs were smaller than in intensively managed monocultures. Bisseleua et al. (2013) 
showed for West African cacao plantations that the higher input needed for intensification not necessarily resulted in higher net returns to the farmer. In the light that cacao monocultures are suffering more from yield reduction due to soil fertility loss, and are more susceptible to herbivore attack and disease infestations (Rice and Greenberg 2000, Belsky and Siebert 2003) and apparently also to drought than shaded cacao systems (Schwendenmann et al. 2010, this study), farmers should be encouraged to choose cultivation systems with diverse shade trees instead of monocultures, where possible.

\subsection{Conclusion}

The present study provides additional evidence that cacao bean yield does not necessarily decrease under a cover of shade trees and that shade seems to reduce physical stress. As demonstrated in our study, somewhat lower fruit production per tree under shade can be compensated by higher tree numbers and the provision of ecosystem services such as enhanced pollination success, biological pest and weed control, increased nitrogen input by legume shade trees and enhanced nutrient cycling with litter fall, as well as a reduced atmospheric vapor demand. Moreover, farmers profit from additional income provided by the harvest of timber, fruits and fuel wood provided by the shade trees. Shade trees could also lead to additional income, when charged within the REDD+ (Reducing Emissions from Deforestation and Forest Degradation) scheme or other certification programs. Our results demonstrate the carbon storage and sequestration potential, which is associated with a shade tree cover in cacao cultivation systems. The additional income and lower labor and input costs make cacao production stable to highly fluctuating cacao prices and more attractive by compensating farmers for possibly lower yields in the short-time compared to monocultures. If planned properly, shaded cacao plantations allow combining high yield with benefits for carbon sequestration, production system stability, and biodiversity.

\section{Acknowledgements}

This study was financed by the German Research Foundation (DFG) in the framework of the interdisciplinary German-Indonesian research project ELUC ('Environmental and land-use change in Sulawesi, Indonesia') and the collaborative research center CRC990 'Ecological and Socioeconomic Functions of Tropical Lowland Rainforest Transformation Systems (Sumatra, Indonesia)', subproject B04. We are very grateful to our local assistants in the Kulawi valley and in Palu for supporting the work. Special thanks go to Andrea Hanf for providing wood samples for carbon content analyses and to Fabian Brambach for the map. We particularly thank RISTEK, the village heads and local plot owners for making this study possible. 


\section{Appendix}

Table A 2.1: Aboveground stand structural properties. Aboveground stand structural properties of the nine study sites of the three cultivation systems in the Kulawi valley (means per plot).

\begin{tabular}{|c|c|c|c|c|c|c|c|c|c|}
\hline $\begin{array}{l}\text { Cultivation } \\
\text { system }\end{array}$ & Plot & $\begin{array}{l}\text { Tree } \\
\text { identity }\end{array}$ & $\begin{array}{l}\text { Canopy cover } \\
(\%)\end{array}$ & $\begin{array}{l}\text { Tree density } \\
\left(\text { no. ha } a^{-1}\right)\end{array}$ & $\begin{array}{l}\text { Stem density } \\
\left(\text { no. ha } a^{-1}\right)\end{array}$ & $\begin{array}{l}\text { Stand basal area } \\
\left(\mathrm{m}^{2} \mathrm{ha}^{-1}\right)\end{array}$ & $\begin{array}{l}\text { Stem diameter } \\
(\mathrm{cm})\end{array}$ & $\begin{array}{l}\text { Tree height } \\
\text { (m) }\end{array}$ & $\begin{array}{l}\text { Shannon- } \\
\text { Index H' }\end{array}$ \\
\hline \multirow[t]{6}{*}{ Cacao-mono } & Plot 1 & Cacao & & 640 & 1280 & 9.01 & 9.03 & 5.16 & \\
\hline & Plot 2 & Cacao & & 1055 & 2012 & 12.06 & 7.60 & 5.14 & \\
\hline & Plot 3 & Cacao & & 982 & 2118 & 16.85 & 9.22 & 5.11 & \\
\hline & Plot 1 & All & 20 & 640 & 1280 & 9.01 & 9.03 & 5.16 & 0 \\
\hline & Plot2 & All & 60 & 1055 & 2012 & 12.06 & 7.60 & 5.14 & 0 \\
\hline & Plot 3 & All & 70 & 982 & 2118 & 16.85 & 9.22 & 5.11 & 0 \\
\hline \multirow{9}{*}{ Cacao-Gliricidia } & Plot 4 & Cacao & & 992 & 2224 & 10.52 & 7.30 & 4.94 & \\
\hline & Plot 5 & Cacao & & 1330 & 3498 & 9.67 & 5.50 & 4.39 & \\
\hline & Plot 6 & Cacao & & 820 & 1892 & 7.48 & 6.72 & 4.51 & \\
\hline & Plot 4 & Shade trees & & 160 & 784 & 4.00 & 7.64 & 10.89 & \\
\hline & Plot 5 & Shade trees & & 494 & 644 & 5.66 & 6.64 & 7.56 & \\
\hline & Plot 6 & Shade trees & & 631 & 725 & 3.66 & 7.83 & 7.20 & \\
\hline & Plot 4 & All & 40 & 1152 & 3008 & 14.52 & 7.39 & 5.76 & 0.17 \\
\hline & Plot 5 & All & 80 & 1824 & 4142 & 15.33 & 6.14 & 5.25 & 0.25 \\
\hline & Plot 6 & All & 60 & 1514 & 2681 & 11.56 & 7.08 & 5.77 & 0.36 \\
\hline \multirow[t]{8}{*}{ Cacao-multi } & Plot 7 & Cacao & & 832 & 1520 & 11.33 & 8.53 & 5.08 & \\
\hline & Plot 8 & Cacao & & 1514 & 2940 & 15.40 & 7.29 & 5.35 & \\
\hline & Plot 9 & Cacao & & 1805 & 2644 & 15.37 & 8.00 & 4.83 & \\
\hline & Plot 7 & Shade trees & & 224 & 224 & 19.99 & 28.05 & 12.72 & \\
\hline & Plot 8 & Shade trees & & 592 & 1119 & 18.25 & 17.65 & 8.47 & \\
\hline & Plot 9 & Shade trees & & 254 & 280 & 23.54 & 28.16 & 14.47 & \\
\hline & Plot 7 & All & 95 & 1056 & 1744 & 31.32 & 10.99 & 6.70 & 0.41 \\
\hline & $\begin{array}{l}\text { Plot } 8 \\
\text { Plot } 9\end{array}$ & $\begin{array}{l}\text { All } \\
\text { All }\end{array}$ & $\begin{array}{l}90 \\
95\end{array}$ & $\begin{array}{l}2107 \\
2060\end{array}$ & $\begin{array}{l}4059 \\
2924\end{array}$ & $\begin{array}{l}33.65 \\
38.91\end{array}$ & $\begin{array}{l}9.04 \\
9.93\end{array}$ & $\begin{array}{l}6.15 \\
6.02\end{array}$ & $\begin{array}{l}0.42 \\
0.27\end{array}$ \\
\hline
\end{tabular}

Table A 2.2: Above- and belowground biomass stocks. Above- and belowground biomass stocks and the shoot:root ratio of the nine study sites of the three cultivation systems in the Kulawi valley (means per plot). Only for the group 'all' fine root data is included.

\begin{tabular}{|c|c|c|c|c|c|c|c|c|}
\hline Cultivation system & Plot & Tree identity & $\begin{array}{l}\text { Aboveground } \\
\text { biomass } \\
\left(\mathrm{Mgha}^{-1}\right)\end{array}$ & $\begin{array}{l}\text { Coarse root } \\
\text { biomass } \\
\left(\mathrm{Mgha}^{-1}\right)\end{array}$ & $\begin{array}{l}\text { Fine root } \\
\text { biomass } \\
\left(\mathrm{Mg} \mathrm{ha}^{-1}\right)\end{array}$ & $\begin{array}{l}\text { Belowground } \\
\text { biomass (note: just } \\
\text { "all" incl. fine roots) } \\
\left(\mathrm{Mg} \mathrm{ha}^{-1}\right)\end{array}$ & $\begin{array}{l}\text { Total above- } \\
\text { and below- } \\
\text { ground biomass } \\
\left(\mathrm{Mg} \mathrm{ha}^{-1}\right)\end{array}$ & $\begin{array}{l}\text { ratio shoot: root } \\
\text { (ratio AGB/BGB) }\end{array}$ \\
\hline \multirow[t]{6}{*}{ Cacao-mono } & Plot 1 & Cacao & 11.93 & 3.13 & & 3.13 & 15.07 & 3.81 \\
\hline & Plot 2 & Cacao & 15.97 & 4.16 & & 4.16 & 20.13 & 3.84 \\
\hline & Plot 3 & Cacao & 22.33 & 5.70 & & 5.70 & 28.03 & 3.92 \\
\hline & Plot 1 & All & 11.93 & 3.13 & 1.04 & 4.17 & 16.10 & 2.86 \\
\hline & Plot 2 & All & 15.97 & 4.16 & 3.22 & 7.38 & 23.35 & 2.16 \\
\hline & Plot 3 & All & 22.33 & 5.70 & 1.94 & 7.64 & 29.97 & 2.92 \\
\hline \multirow[t]{9}{*}{ Cacao-Gliricidia } & Plot 4 & Cacao & 13.91 & 3.78 & & 3.78 & 17.69 & 3.67 \\
\hline & Plot 5 & Cacao & 12.73 & 3.69 & & 3.69 & 16.42 & 3.45 \\
\hline & Plot 6 & Cacao & 9.87 & 2.79 & & 2.79 & 12.66 & 3.54 \\
\hline & Plot 4 & Shade trees & 19.00 & 4.47 & & 4.47 & 23.47 & 4.25 \\
\hline & Plot 5 & Shade trees & 19.34 & 4.31 & & 4.31 & 23.66 & 4.48 \\
\hline & Plot 6 & Shade trees & 13.74 & 3.37 & & 3.37 & 17.11 & 4.08 \\
\hline & Plot 4 & All & 32.91 & 8.25 & 3.13 & 11.38 & 44.29 & 2.89 \\
\hline & Plot 5 & All & 32.07 & 8.00 & 3.57 & 11.57 & 43.64 & 2.77 \\
\hline & Plot 6 & All & 23.61 & 6.16 & 2.36 & 8.52 & 32.13 & 2.77 \\
\hline \multirow[t]{9}{*}{ Cacao-multi } & Plot 7 & Cacao & 15.01 & 3.83 & & 3.83 & 18.84 & 3.92 \\
\hline & Plot 8 & Cacao & 20.37 & 5.41 & & 5.41 & 25.78 & 3.77 \\
\hline & Plot 9 & Cacao & 20.34 & 5.41 & & 5.41 & 25.75 & 3.76 \\
\hline & Plot 7 & Shade trees & 100.20 & 15.45 & & 15.45 & 115.65 & 6.48 \\
\hline & Plot 8 & Shade trees & 61.10 & 11.20 & & 11.20 & 72.30 & 5.46 \\
\hline & Plot 9 & Shade trees & 85.89 & 14.56 & & 14.56 & 100.45 & 5.90 \\
\hline & Plot 7 & All & 115.20 & 19.28 & 6.48 & 25.76 & 140.97 & 4.47 \\
\hline & Plot 8 & All & 81.47 & 16.61 & 3.01 & 19.62 & 101.09 & 4.15 \\
\hline & Plot 9 & All & 106.23 & 19.97 & 3.45 & 23.42 & 129.65 & 4.54 \\
\hline
\end{tabular}


Table A 2.3: Above- and belowground carbon stocks. Above- and belowground carbon stocks and the shoot:root carbon ratio of the nine study sites of the three cultivation systems in the Kulawi valley (means per plot). Only for the group 'all' fine root data is included.

\begin{tabular}{|c|c|c|c|c|c|c|c|c|}
\hline Cultivation system & Plot & Tree identity & $\begin{array}{l}\text { Aboveground } \\
\text { carbon stock } \\
\left(\mathrm{Mg} \mathrm{ha}^{-1}\right)\end{array}$ & $\begin{array}{l}\text { Coarse root } \\
\text { carbon } \\
\text { stock } \\
\left(\mathrm{Mg} \mathrm{ha}^{-t}\right)\end{array}$ & $\begin{array}{l}\text { Fine root } \\
\text { carbon } \\
\text { stock } \\
\left(\mathrm{Mg} \mathrm{ha}^{-1}\right)\end{array}$ & $\begin{array}{l}\text { Total } \\
\text { Belowground } \\
\text { carbon stock } \\
\text { (note: just "all" } \\
\text { incl. fine roots) } \\
\left(\mathrm{Mg} \mathrm{ha}^{-1}\right)\end{array}$ & $\begin{array}{l}\text { Total above- } \\
\text { and } \\
\text { belowground } \\
\text { carbon stock } \\
\left(\mathrm{Mg} \mathrm{ha} \mathrm{a}^{-1}\right)\end{array}$ & $\begin{array}{l}\text { ratio } \\
\text { shoot } \mathrm{C}: \operatorname{root} \mathrm{C}\end{array}$ \\
\hline \multirow[t]{6}{*}{ Cacao-mono } & Plot 1 & Cacao & 5.52 & 1.32 & & 1.32 & 6.83 & 4.19 \\
\hline & Plot 2 & Cacao & 7.39 & 1.82 & & 1.82 & 9.21 & 4.05 \\
\hline & Plot 3 & Cacao & 10.33 & 2.60 & & 2.60 & 12.93 & 3.97 \\
\hline & Plot 1 & All & 5.52 & 1.32 & 0.45 & 1.77 & 7.28 & 3.12 \\
\hline & Plot2 & All & 7.38 & 1.82 & 1.43 & 3.26 & 10.64 & 2.27 \\
\hline & Plot 3 & All & 10.33 & 2.60 & 0.85 & 3.45 & 13.78 & 2.99 \\
\hline \multirow[t]{9}{*}{ Cacao-Gliricidia } & Plot 4 & Cacao & 6.43 & 1.68 & & 1.68 & 8.11 & 3.83 \\
\hline & Plot 5 & Cacao & 5.89 & 1.54 & & 1.54 & 7.43 & 3.82 \\
\hline & Plot 6 & Cacao & 4.57 & 1.31 & & 1.31 & 5.87 & 3.49 \\
\hline & Plot 4 & Shade trees & 9.18 & 1.62 & & 1.62 & 10.80 & 5.66 \\
\hline & Plot 5 & Shade trees & 9.34 & 2.35 & & 2.35 & 11.69 & 3.97 \\
\hline & Plot 6 & Shade trees & 6.64 & 2.31 & & 2.31 & 8.95 & 2.87 \\
\hline & Plot 4 & All & 15.61 & 3.50 & 1.34 & 4.84 & 20.45 & 3.23 \\
\hline & Plot 5 & All & 15.23 & 3.25 & 1.44 & 4.69 & 19.91 & 3.25 \\
\hline & Plot 6 & All & 11.20 & 2.71 & 0.98 & 3.69 & 14.89 & 3.03 \\
\hline \multirow[t]{8}{*}{ Cacao-multi } & Plot 7 & Cacao & 6.94 & 1.82 & & 1.82 & 8.76 & 3.81 \\
\hline & Plot 8 & Cacao & 9.42 & 1.71 & & 1.71 & 11.13 & 5.52 \\
\hline & Plot9 & Cacao & 9.41 & 1.41 & & 1.41 & 10.81 & 6.69 \\
\hline & Plot 7 & Shade trees & 47.43 & 6.45 & & 6.45 & 53.88 & 7.35 \\
\hline & Plot \& & Shade trees & 28.93 & 4.84 & & 4.84 & 33.76 & 5.98 \\
\hline & Plot 9 & Shade trees & 40.66 & 6.33 & & 6.33 & 46.99 & 6.42 \\
\hline & Plot 7 & All & 54.37 & 8.07 & 2.77 & 10.85 & 65.22 & 5.01 \\
\hline & $\begin{array}{l}\text { Plot } 8 \\
\text { Plot } 9\end{array}$ & $\begin{array}{l}\text { All } \\
\text { All }\end{array}$ & $\begin{array}{l}38.35 \\
50.06\end{array}$ & $\begin{array}{l}7.19 \\
8.64\end{array}$ & $\begin{array}{l}1.16 \\
1.44\end{array}$ & $\begin{array}{l}8.35 \\
10.08\end{array}$ & $\begin{array}{l}46.70 \\
60.14\end{array}$ & $\begin{array}{l}4.59 \\
4.97\end{array}$ \\
\hline
\end{tabular}

Table A 2.4: Net primary production (NPP). Components of annual net primary production (NPP) (in Mg ha-1 yr-1) of the nine study sites of the three cultivation systems in the Kulawi valley (means per plot). Note that coarse root biomass production includes production of root stocks as well.

\begin{tabular}{|c|c|c|c|c|c|c|c|c|c|c|c|}
\hline $\begin{array}{l}\text { Cultivation } \\
\text { system }\end{array}$ & Plot & $\begin{array}{l}\text { Tree } \\
\text { identity }\end{array}$ & $\begin{array}{l}\text { Cacao } \\
\text { bean } \\
\text { yield }\end{array}$ & $\begin{array}{l}\text { Cacao fruit } \\
\text { production }\end{array}$ & $\begin{array}{l}\text { Aboveground } \\
\text { woody biomass } \\
\text { production }\end{array}$ & $\begin{array}{l}\text { Litter } \\
\text { production }\end{array}$ & $\begin{array}{l}\text { Fine root } \\
\text { production }\end{array}$ & $\begin{array}{l}\text { Coarse } \\
\text { root } \\
\text { biomass } \\
\text { production }\end{array}$ & $\begin{array}{l}\text { Total } \\
\text { aboveground } \\
\text { production }\end{array}$ & $\begin{array}{l}\text { Total } \\
\text { belowground } \\
\text { production }\end{array}$ & $\begin{array}{l}\text { Total } \\
\text { production }\end{array}$ \\
\hline \multirow[t]{6}{*}{ Cacao-mono } & Plot 1 & Cacao & 1.57 & 5.06 & 1.75 & 4.41 & 0.51 & 0.41 & 11.23 & 0.92 & 12.14 \\
\hline & Plot 2 & Cacao & 2.18 & 10.58 & 1.40 & 5.11 & 3.38 & 0.32 & 17.10 & 3.70 & 20.80 \\
\hline & Plot 3 & Cacao & 2.61 & 13.37 & 3.84 & 6.43 & 1.13 & 0.87 & 23.64 & 2.00 & 25.63 \\
\hline & Plot 1 & All & & & 1.75 & 4.41 & 0.51 & 0.41 & 11.23 & 0.92 & 12.14 \\
\hline & Plot2 & All & & & 1.40 & 5.11 & 3.38 & 0.32 & 17.10 & 3.70 & 20.80 \\
\hline & Plot 3 & All & & & 3.84 & 6.43 & 1.13 & 0.87 & 23.64 & 2.00 & 25.63 \\
\hline \multirow[t]{9}{*}{ Сасаo-Gliricidia } & Plot 4 & Cacao & 1.95 & 9.68 & 4.06 & 2.39 & 1.35 & 0.97 & 16.13 & 2.32 & 18.45 \\
\hline & Plot 5 & Cacao & 3.19 & 16.23 & 2.49 & 4.02 & 1.25 & 0.63 & 22.74 & 1.88 & 24.62 \\
\hline & Plot 6 & Cacao & 1.23 & 6.76 & 2.78 & 2.42 & 1.40 & 0.67 & 11.96 & 2.08 & 14.03 \\
\hline & Plot 4 & Shade trees & & & 7.75 & 1.49 & 1.08 & 1.58 & 9.24 & 2.66 & 11.90 \\
\hline & Plot 5 & Shade trees & & & 5.85 & 2.50 & 0.51 & 1.14 & 8.35 & 1.64 & 9.99 \\
\hline & Plot 6 & Shade trees & & & 3.56 & 1.23 & 0.14 & 0.75 & 4.80 & 0.89 & 5.69 \\
\hline & Plot 4 & All & & & 11.81 & 3.88 & 2.43 & 2.55 & 25.37 & 4.98 & 30.34 \\
\hline & Plot 5 & All & & & 8.34 & 6.52 & 1.75 & 1.76 & 31.09 & 3.52 & 34.61 \\
\hline & Plot 6 & All & & & 6.34 & 3.65 & 1.54 & 1.43 & 16.75 & 2.97 & 19.72 \\
\hline \multirow[t]{9}{*}{ Cacao-multi } & Plot 7 & Cacao & 2.26 & 10.58 & 1.21 & 2.57 & 1.38 & 0.27 & 14.35 & 1.65 & 16.00 \\
\hline & Plot 8 & Cacao & 0.76 & 3.92 & 4.76 & 2.68 & 0.61 & 1.11 & 11.36 & 1.72 & 13.08 \\
\hline & Plot 9 & Cacao & 2.99 & 10.32 & 2.42 & 3.36 & 1.39 & 0.56 & 16.10 & 1.95 & 18.05 \\
\hline & Plot 7 & Shade trees & & & 10.17 & 7.29 & 0.36 & 1.40 & 17.45 & 1.77 & 19.22 \\
\hline & Plot8 & Shade trees & & & 14.60 & 7.94 & 0.60 & 2.30 & 22.54 & 2.90 & 25.44 \\
\hline & Plot 9 & Shade trees & & & 13.54 & 5.35 & 0.24 & 2.11 & 18.89 & 2.35 & 21.23 \\
\hline & Plot 7 & All & & & 11.38 & 9.85 & 1.74 & 1.68 & 31.80 & 3.42 & 35.22 \\
\hline & Plot 8 & All & & & 19.37 & 10.61 & 1.21 & 3.41 & 33.90 & 4.62 & 38.52 \\
\hline & Plot 9 & All & & & 15.96 & 8.71 & 1.63 & 2.67 & 34.99 & 4.30 & 39.29 \\
\hline
\end{tabular}


Table A 2.5: Carbon pools in net primary production (NPP). Associated carbon pools (in $\mathrm{Mg} \mathrm{C}$ ha-1 yr-1) in annual net primary production (NPP) of the nine study sites of the three cultivation systems in the Kulawi valley (means per plot). Note that coarse root biomass production includes production of root stocks as well.

\begin{tabular}{|c|c|c|c|c|c|c|c|c|c|c|c|}
\hline Cultivation system & Plot & Tree identity & $\begin{array}{l}\mathrm{C} \text { in } \\
\text { Cacao } \\
\text { bean } \\
\text { yield }\end{array}$ & $\begin{array}{l}\text { C in Cacao } \\
\text { fruit } \\
\text { production }\end{array}$ & $\begin{array}{l}\text { C in } \\
\text { Above- } \\
\text { ground } \\
\text { woody } \\
\text { biomass } \\
\text { production }\end{array}$ & $\begin{array}{l}\mathrm{C} \text { in Litter } \\
\text { production }\end{array}$ & $\begin{array}{l}\mathrm{C} \text { in Fine } \\
\text { root } \\
\text { production } \\
(0-60 \mathrm{~cm})\end{array}$ & $\begin{array}{l}\mathrm{C} \text { in Coarse } \\
\text { root biomass } \\
\text { production }\end{array}$ & $\begin{array}{l}\mathrm{C} \text { in Total } \\
\text { aboveground } \\
\text { production }\end{array}$ & $\begin{array}{l}\mathrm{C} \text { in Total } \\
\text { belowground } \\
\text { production }\end{array}$ & $\begin{array}{l}\mathrm{C} \text { in Total } \\
\text { production }\end{array}$ \\
\hline \multirow[t]{6}{*}{ Cacao-mono } & Plot 1 & Cacao & 0.88 & 2.29 & 0.81 & 1.86 & 0.23 & 0.17 & 5.35 & 4.95 & 0.40 \\
\hline & Plot2 & Сасаo & 1.22 & 5.30 & 0.65 & 2.40 & 1.52 & 0.14 & 10.02 & 8.36 & 1.66 \\
\hline & Plot3 3 & Сасао & 1.46 & 6.36 & 1.78 & 3.00 & 0.48 & 0.40 & 12.01 & 11.13 & 0.88 \\
\hline & Plot 1 & All & & & 0.81 & 1.86 & 0.23 & 0.17 & 5.35 & 4.95 & 0.40 \\
\hline & Plot2 & All & & & 0.65 & 2.40 & 1.52 & 0.14 & 10.02 & 8.36 & 1.66 \\
\hline & Plot 3 & All & & & 1.78 & 3.00 & 0.48 & 0.40 & 12.01 & 11.13 & 0.88 \\
\hline \multirow[t]{9}{*}{ Cacao-Gliricidia } & Plot 4 & Сacao & 1.09 & 4.89 & 1.88 & 1.08 & 0.61 & 0.43 & 8.88 & 7.84 & 1.04 \\
\hline & Plot 5 & Сасаo & 1.79 & 7.94 & 1.15 & 1.84 & 0.53 & 0.26 & 11.72 & 10.93 & 0.79 \\
\hline & Plot 6 & Сасаo & 0.69 & 3.49 & 1.28 & 1.11 & 0.62 & 0.32 & 6.82 & 5.89 & 0.93 \\
\hline & Plot 4 & Shade trees & & & 3.74 & 0.71 & 0.46 & 0.64 & 5.56 & 4.45 & 1.11 \\
\hline & Plot 5 & Shade trees & & & 2.83 & 1.18 & 0.19 & 0.45 & 4.65 & 4.01 & 0.64 \\
\hline & Plot 6 & Shade trees & & & 1.72 & 0.60 & 0.06 & 0.31 & 2.69 & 2.32 & 0.37 \\
\hline & Plot 4 & All & & & 5.62 & 1.79 & 1.07 & 1.07 & 14.44 & 10.83 & 1.83 \\
\hline & Plot 5 & All & & & 3.98 & 3.02 & 0.72 & 0.71 & 16.37 & 14.79 & 2.04 \\
\hline & Plot 6 & All & & & 3.00 & 1.72 & 0.67 & 0.63 & 9.51 & 9.82 & 1.01 \\
\hline \multirow[t]{9}{*}{ Cacao-multi } & Plot 7 & Сacao & 1.27 & 5.20 & 0.56 & 1.14 & 0.59 & 0.12 & 7.60 & 6.90 & 0.70 \\
\hline & Plot8 & Сасао & 0.43 & 1.93 & 2.20 & 1.23 & 0.25 & 0.48 & 6.09 & 5.36 & 0.73 \\
\hline & Plot9 & Сасао & 1.67 & 5.09 & 1.12 & 1.55 & 0.59 & 0.24 & 8.59 & 7.76 & 0.83 \\
\hline & Plot 7 & Shade trees & & & 4.81 & 3.44 & 0.15 & 0.59 & 9.00 & 8.26 & 0.74 \\
\hline & Plot 8 & Shade trees & & & 6.91 & 3.70 & 0.22 & 0.99 & 11.83 & 10.61 & 1.21 \\
\hline & Plot9 & Shade trees & & & 6.41 & 2.56 & 0.09 & 0.92 & 9.97 & 8.97 & 1.01 \\
\hline & Plot 7 & All & & & 5.37 & 4.58 & 0.74 & 0.70 & 16.60 & 10.32 & 1.44 \\
\hline & Plot 8 & All & & & 9.12 & 4.92 & 0.47 & 1.48 & 17.92 & 12.86 & 1.57 \\
\hline & Plot9 & All & & & 7.53 & 4.11 & 0.68 & 1.16 & 18.56 & 24.67 & 2.22 \\
\hline
\end{tabular}




\section{References}

Achard, F., H. D. Eva, H.-J. Stibig, P. Mayaux, J. Gallego, T. Richards, and J.-P. Malingreau. 2002. Determination of deforestation rates of the world's humid tropical forests. Science 297:999-1002.

Arnold, A. E., L. C. Mejía, D. Kyllo, E. I. Rojas, Z. Maynard, N. Robbins, and E. A. Herre. 2003. Fungal endophytes limit pathogen damage in a tropical tree. Proceedings of the National Academy of Sciences of the United States of America 100:15649-15654.

Baker, T. R., O. L. Phillips, Y. Malhi, S. Almeida, L. Arroyo, A. Di Fiore, T. Erwin, T. J. Killeen, S. G. Laurance, W. F. Laurance, S. L. Lewis, J. Lloyd, A. Monteagudo, D. A. Neill, S. Patiño, N. C. A. Pitman, J. N. M. Silva, and R. Vásquez Martínez. 2004. Variation in wood density determines spatial patterns in Amazonian forest biomass. Global Change Biology 10:545-562.

Balasimha, D., E. V. Daniel, and P. G. Bhat. 1991. Influence of environmental factors on photosynthesis in cocoa trees. Agricultural and forest meteorology 55:15-21.

Baligar, V. C., J. A. Bunce, R. C. R. Machado, and M. K. Elson. 2008. Photosynthetic photon flux density, carbon dioxide concentration, and vapor pressure deficit effects on photosynthesis in cacao seedlings. Photosynthetica 46:216-221.

Beer, J. 1987. Advantages, disadvantages and desirable characteristics of shade trees for coffee, cacao and tea. Agroforestry systems 5:3-13.

Beer, J., A. Bonnemann, W. Chavez, H. W. Fassbender, A. C. Imbach, and I. Martel. 1990. Modelling agroforestry systems of cacao (Theobroma cacao) with laurel (Cordia alliodora) or poro (Erythrina poeppigiana) in Costa Rica. Agroforestry Systems 12:229-249.

Beer, J., R. Muschler, D. Kass, and E. Somarriba. 1998. Shade management in coffee and cacao plantations. Agroforestry Systems 38:139-164.

Belsky, J., and S. F. Siebert. 2003. Cultivating cacao: Implications of sun-grown cacao on local food security and environmental sustainability. Agriculture and Human Values 20:277-285.

Bisseleua, D. H. B., A. D. Missoup, and S. Vidal. 2009. Biodiversity conservation, ecosystem functioning, and economic incentives under cocoa agroforestry intensification. Conservation Biology 23:1176-1184.

Bisseleua, H. B. D., D. Fotio, Yede, A. D. Missoup, and S. Vidal. 2013. Shade tree diversity, cocoa pest damage, yield compensating inputs and farmers' net returns in West Africa. PloS one 8:e56115. 
Bos, M. M., I. Steffan-Dewenter, and T. Tscharntke. 2007. Shade tree management affects fruit abortion, insect pests and pathogens of cacao. Agriculture, Ecosystems and Environment 120:201-205.

Bowers, J. H., B. A. Bailey, P. K. Hebbar, S. Sanogo, and R. D. Lumsden. 2001. The Impact of Plant Diseases on World Chocolate Production. Online. Plant Health Progress. doi:10.1094/PHP-2001-0709-01-RV.

Cairns, M., S. Brown, E. Helmer, and G. Baumgardner. 1997. Root biomass allocation in the world's upland forests. Oecologia 111:1-11.

Chave, J., C. Andalo, S. Brown, M. A. Cairns, J. Q. Chambers, D. Eamus, H. Fölster, F. Fromard, N. Higuchi, T. Kira, J.-P. Lescure, B. W. Nelson, H. Ogawa, H. Puig, B. Riéra, and T. Yamakura. 2005. Tree allometry and improved estimation of carbon stocks and balance in tropical forests. Oecologia 145:87-99.

Clough, Y., J. Barkmann, J. Juhrbandt, M. Kessler, T. C. Wanger, A. Anshary, D. Buchori, D. Cicuzza, K. Darras, D. D. Putra, S. Erasmi, R. Pitopang, C. Schmidt, C. H. Schulze, D. Seidel, I. Steffan-Dewenter, K. Stenchly, S. Vidal, M. Weist, A. C. Wielgoss, and T. Tscharntke. 2011. Combining high biodiversity with high yields in tropical agroforests. Proceedings of the National Academy of Sciences of the United States of America 108:8311-8316.

Clough, Y., H. Faust, and T. Tscharntke. 2009. Cacao boom and bust: sustainability of agroforests and opportunities for biodiversity conservation. Conservation Letters 2:197205.

DeFries, R., F. Achard, S. Brown, M. Herold, D. Murdiyarso, B. Schlamadinger, and C. de Souza Jr. 2007. Earth observations for estimating greenhouse gas emissions from deforestation in developing countries. Environmental science \& Policy 10:385-394.

DeFries, R., R. A. Houghton, M. C. Hansen, C. B. Field, D. Skole, and J. Townshend. 2002. Carbon emissions from tropical deforestation and regrowth based on satellite observations for the 1980s and 1990s. Proceedings of the National Academy of Sciences of the United States of America 99:14256-14261.

Duguma, B., J. Gockowski, and J. Bakala. 2001. Smallholder cacao (Theobroma cacao Linn.) cultivation in agroforestry systems of West and Central Africa: challenges and opportunities. Agroforestry systems 51:177-188.

Ewel, J., and M. J. Mazzarino. 2008. Competition from below for light and nutrients shifts productivity among tropical species. Proceedings of the National Academy of Sciences of the United States of America 105:18836-18841.

FAO Statistical Databases: http://faostat.fao.org Food and Agriculture Organization of the United Nations. FAO, Rome, Italy. (Accessed Sep 2014) 
Frimpong, E A., B. Gemmill-Herren, I. Gordon, and P. K. Kwapong. 2011. Dynamics of insect pollinators as influenced by cocoa production systems in Ghana. Journal of Pollination Ecology 5:74-80.

Fuentes-Talavera, F. J., J. A. Silva-Guzmán, R. Rodríguez-Anda, M. G. Lomelí-Ramírez, R. Sanjuán-Dueñas, and H. G. Richter. 2011. Strength properties and natural durability of Avocado ( Persea americana Mill .) branch wood. Madera y Bosques 17:37-47.

Gockowski, J., and D. Sonwa. 2011. Cocoa intensification scenarios and their predicted impact on $\mathrm{CO} 2$ emissions, biodiversity conservation, and rural livelihoods in the Guinea rain forest of West Africa. Environmental Management 48:307-321.

Gordon, C., R. Manson, J. Sundberg, and A. Cruz-Angón. 2007. Biodiversity, profitability, and vegetation structure in a Mexican coffee agroecosystem. Agriculture, Ecosystems and Environment 118:256-266.

Groeneveld, J. H., T. Tscharntke, G. Moser, and Y. Clough. 2010. Experimental evidence for stronger cacao yield limitation by pollination than by plant resources. Perspectives in Plant Ecology, Evolution and Systematics 12:183-191.

Hairiah, K., S. Sitompul, M. Van Noordwijk, and C. Palm. 2001. Methods for sampling carbon stocks above and below ground. Page 32 ASB Lecture Note, International Centre for Research in Agroforestry.

Hansen, M. C., P. V. Potapov, R. Moore, M. Hancher, S. A. Turubanova, A. Tyukavina, D. Thau, S. V. Stehman, S. J. Goetz, T. R. Loveland, A. Kommareddy, A. Egorov, L. Chini, C. O. Justice, and J. R. G. Townshend. 2013. High-resolution global maps of 21st-century forest cover change. Science 342:850-3.

Harris, N. L., S. Brown, S. C. Hagen, S. S. Saatchi, S. Petrova, W. Salas, M. C. Hansen, P. V. Potapov, and A. Lotsch. 2012. Baseline map of carbon emissions from deforestation in tropical regions. Science 336:1573-1576.

Hertel, D., and C. Leuschner. 2002. A comparison of four different fine root production estimates with ecosystem carbon balance data in a Fagus-Quercus mixed forest. Plant and Soil 239:237-251.

Hertel, D., T. Strecker, H. Müller-Haubold, and C. Leuschner. 2013. Fine root biomass and dynamics in beech forests across a precipitation gradient - Is optimal resource partitioning theory applicable to water-limited mature trees? Journal of Ecology 101:1183-1200.

Houghton, R. A., D. L. Skole, C. A. Nobre, J. L. Hackler, K. T. Lawrence, and W. H. Chomentowski. 2000. Annual fluxes of carbon from deforestation and regrowth in the Brazilian Amazon. Nature 403:301-304. 
Isaac, M. E., V. R. Timmer, and S. J. Quashie-Sam. 2007. Shade tree effects in an 8-year-old cocoa agroforestry system: biomass and nutrient diagnosis of Theobroma cacao by vector analysis. Nutrient Cycling in Agroecosystems 78:155-165.

Johns, N. D. 1999. Conservation in Brazil's chocolate forest: the unlikely persistence of the traditional cocoa agroecosystem. Environmental Management 23:31-47.

Klein, A.-M., I. Steffan-Dewenter, and T. Tscharntke. 2002. Predator-prey ratios on cocoa along a land-use gradient in Indonesia. Biodiversity and Conservation 11:683-693.

Köhler, M., D. Dierick, L. Schwendenmann, and D. Hölscher. 2009. Water use characteristics of cacao and Gliricidia trees in an agroforest in Central Sulawesi, Indonesia. Ecohydrology 2:520-529.

Köhler, M., A. Hanf, H. Barus, Hendrayanto and D. Hölscher. 2014. Cacao trees under different shade tree shelter: effects on water use. Agroforestry systems 88:63-73.

Kotowska, M. M., D. Hertel, Y. Abou Rajab, H. Barus, and B. Schuldt. 2015. Patterns in hydraulic architecture from roots to branches in six tropical tree species from cacao agroforestry and their relation to wood density and stem growth. Frontiers in Plant Science 6:1-16.

Lehmann, J. 2003. Subsoil root activity in tree-based cropping systems. Plant and Soil 255:319-331.

Leuschner, C., D. Hertel, H. Coners, and V. Büttner. 2001. Root competition between beech and oak: a hypothesis. Oecologia 126:276-284.

Leuschner, C., G. Moser, D. Hertel, S. Erasmi, D. Leitner, H. Culmsee, B. Schuldt, and L. Schwendenmann. 2013. Conversion of tropical moist forest into cacao agroforest: consequences for carbon pools and annual C sequestration. Agroforestry Systems 87:1173-1187.

Margono, B. A., P. V. Potapov, S. Turubanova, F. Stolle, and M. Hansen. 2014. Primary forest cover loss in Indonesia over 2000-2012. Nature Climate Change 4:1-6.

Margono, B. A., S. Turubanova, I. Zhuravleva, P. Potapov, A. Tyukavina, A. Baccini, S. Goetz, and M. C. Hansen. 2012. Mapping and monitoring deforestation and forest degradation in Sumatra (Indonesia) using Landsat time series data sets from 1990 to 2010. Environmental Research Letters 7:034010.

Miettinen, J., C. Shi, and S. C. Liew. 2011. Deforestation rates in insular Southeast Asia between 2000 and 2010. Global Change Biology 17:2261-2270.

Miyaji, K.-I., W. S. Da Silva, and P. D. T. Alvim. 1997. Longevity of leaves of a tropical tree, Theobroma cacao, grown under shading, in relation to position within the canopy and time of emergence. New phytologist 135:445-454. 
Montagnini, F., and P. Nair. 2004. Carbon sequestration: an underexploited environmental benefit of agroforestry systems. Agroforestry systems 61:281-295.

Moser, G., C. Leuschner, D. Hertel, D. Hölscher, M. Köhler, D. Leitner, B. Michalzik, E. Prihastanti, S. Tjitrosemito, and L. Schwendenmann. 2010. Response of cocoa trees (Theobroma cacao) to a 13-month desiccation period in Sulawesi, Indonesia. Agroforestry Systems 79:171-187.

Nair, P. K. R., V. D. Nair, B. M. Kumar, and J. M. Showalter. 2010. Carbon sequestration in agroforestry systems. (D. L. Sparks, Ed.), pp. 237-307. Advances in Agronomy. 2010 Elsevier Inc.

Obiri, B. D., G. A. Bright, M. A. McDonald, L. C. N. Anglaaere, and J. Cobbina. 2007. Financial analysis of shaded cocoa in Ghana. Agroforestry Systems 71:139-149.

Ong, C. K., J. E. Corlett, R. P. Singh, and C. R. Black. 1991. Above and below ground interactions in agroforestry systems. Forest Ecology and Management 45:45-57.

Ong, C.K., R.M. Kho, and S. Radersma. 2004. Ecological interactions in multi-species agroecosystems: concepts and rules. in: Below-ground Interactions in Tropical Agroecosystems. Concepts and Models with Multiple Plant Components (eds M. van Noordwijk, G. Cadisch and C.K. Ong), pp. 1-15. CABI Publishing, Wallingford.

Perfecto, I., I. Armbrecht, S. M. Philpott, L. Soto-Pinto, and T. V Dietsch. 2007. Shaded coffee and the stability of rainforest margins in northern Latin America. in: $\mathrm{T}$. Tscharntke, C. Leuschner, M. Zelle, E. Guhardja, and Bidin A (eds), The stability of tropical rainforest margins, linking ecological, economic and social constraints of land use and conservation. Springer Verlag Berlin 2007, pp 227-263

Perfecto, I., and J. Vandermeer. 2010. The agroecological matrix as alternative to the landsparing/agriculture intensification model. Proceedings of the National Academy of Sciences of the United States of America 107:5786-5791.

Persson, H. 1980. Fine-root dynamics in a Scots pine stand with and without near optimum nutrient and water regimes. Acta Phytogeographica Suecica 68:101-110.

Philpott, S. M., O. Soong, J. H. Lowenstein, A. L. Pulido, D. T. Lopez, D. F. B. Flynn, and F. De Clerck. 2009. Functional richness and ecosystem services: bird predation on arthropods in tropical agroecosystems. Ecological Applications 19:1858-1867.

Rice, R. A., and R. Greenberg. 2000. Cacao Cultivation and the Conservation of Biological Diversity. AMBIO: A Journal of the Human Environment 29:167-173.

Ruf, F., Jamaluddin, Yoddang, and W. Ardhy. 1995. The "spectacular" Efficiency of Cacao Smallholders in Sulawesi: Why? Until When? Pages 339-369 in F. Ruf and P. S. Siswoputranto, editors. Cacao Cycles- The Economics of Cacao Supply. Woodhead Publishing, Ltd. Cambridge, England. 
Saatchi, S. S., N. L. Harris, S. Brown, M. Lefsky, E. T. A. Mitchard, W. Salas, B. R. Zutta, W. Buermann, S. L. Lewis, S. Hagen, S. Petrova, L. White, M. Silman, and A. Morel. 2011. Benchmark map of forest carbon stocks in tropical regions across three continents. Proceedings of the National Academy of Sciences of the United States of America 108:9899-904.

Saj, S., P. Jagoret, and H. T. Ngogue. 2013. Carbon storage and density dynamics of associated trees in three contrasting Theobroma cacao agroforests of Central Cameroon. Agroforestry Systems 87:1309-1320.

Schroth, G., S. A. D’Angelo, W. G. Teixeira, D. Haag, and R. Lieberei. 2002. Conversion of secondary forest into agroforestry and monoculture plantations in Amazonia: consequences for biomass, litter and soil carbon stocks after 7 years. Forest Ecology and Management 163:131-150.

Schroth, G., and Harvey, C. A. 2007. Biodiversity conservation in cocoa production landscapes: an overview. Biodiversity and Conservation, 16: 2237-2244.

Schwendenmann, L., E. Veldkamp, G. Moser, D. Hölscher, M. Köhler, Y. Clough, I. Anas, G. Djajakirana, S. Erasmi, D. Hertel, D. Leitner, C. Leuschner, B. Michalzik, P. Propastin, A. Tjoa, T. Tscharntke, and O. van Straaten. 2010. Effects of an experimental drought on the functioning of a cacao agroforestry system, Sulawesi, Indonesia. Global Change Biology 16:1515-1530.

Siebert, S. F. 2002. From shade- to sun-grown perennial crops in Sulawesi, Indonesia: Implications for biodiversity conservation and soil fertility. Biodiversity and Conservation 11:1889-1902.

Smiley, G. L., and J. Kroschel. 2010. Yield development and nutrient dynamics in cocoagliricidia agroforests of Central Sulawesi, Indonesia. Agroforestry Systems 78:97-114.

Somarriba, E., R. Cerda, L. Orozco, M. Cifuentes, H. Dávila, T. Espin, H. Mavisoy, G. Ávila, E. Alvarado, V. Poveda, C. Astorga, E. Say, and O. Deheuvels. 2013. Carbon stocks and cocoa yields in agroforestry systems of Central America. Agriculture, Ecosystems \& Environment 173:46-57.

Steffan-Dewenter, I., M. Kessler, J. Barkmann, M. M. Bos, D. Buchori, S. Erasmi, H. Faust, G. Gerold, K. Glenk, S. R. Gradstein, E. Guhardja, M. Harteveld, D. Hertel, P. Höhn, M. Kappas, S. Köhler, C. Leuschner, M. Maertens, R. Marggraf, S. Migge-Kleian, J. Mogea, R. Pitopang, M. Schaefer, S. Schwarze, S. G. Sporn, A. Steingrebe, S. S. Tjitrosoedirdjo, S. Tjitrosemito, A. Twele, R. Weber, L. Woltmann, M. Zeller, and T. Tscharntke. 2007. Tradeoffs between income, biodiversity, and ecosystem functioning during tropical rainforest conversion and agroforestry intensification. Proceedings of the National Academy of Sciences of the United States of America 104:4973-4978. 
Tscharntke, T., Y. Clough, S. A. Bhagwat, D. Buchori, H. Faust, D. Hertel, D. Hölscher, J. Juhrbandt, M. Kessler, I. Perfecto, C. Scherber, G. Schroth, E. Veldkamp, and T. C. Wanger. 2011. Multifunctional shade-tree management in tropical agroforestry landscapes - A review. Journal of Applied Ecology 48:619-629.

Tscharntke, T., Y. Clough, T. C. Wanger, L. Jackson, I. Motzke, I. Perfecto, J. Vandermeer, and A. Whitbread. 2012. Global food security, biodiversity conservation and the future of agricultural intensification. Biological Conservation 151:53-59.

Van Noordwijk, M., and R. Mulia. 2002. Functional branch analysis as tool for fractal scaling above and belowground trees for their additive and non-additive properties. Ecological Modelling 149:41-51.

Van Praag, H. J., S. Sougnez-Remy, F. Weissen, and G. Carletti. 1988. Root turnover in a beech and a spruce stand of the Belgian Ardennes. Plant and Soil 105:87-103.

Vogt, K. A., D. J. Vogt, and J. Bloomfield. 1998. Analysis of some direct and indirect methods for estimating root biomass and production of forests at an ecosystem level. Plant and Soil 200:71-89.

Wade, A. S. I., A. Asase, P. Hadley, J. Mason, K. Ofori-Frimpong, D. Preece, N. Spring, and K. Norris. 2010. Management strategies for maximizing carbon storage and tree species diversity in cocoa-growing landscapes. Agriculture, Ecosystems and Environment 138:324-334.

Wielgoss, A., Y. Clough, B. Fiala, A. Rumede, and T. Tscharntke. 2012. A minor pest reduces yield losses by a major pest: Plant-mediated herbivore interactions in Indonesian cacao. Journal of Applied Ecology 49:465-473.

Wilcove, D. S., X. Giam, D. P. Edwards, B. Fisher, and L. P. Koh. 2013. Navjot's nightmare revisited: Logging, agriculture, and biodiversity in Southeast Asia. Trends in Ecology and Evolution 28:531-540.

World Agroforestry Center (2014) Wood density database. Available at http://www.worldagroforestry.org/sea/Products/AFDbases/WD/. (Accessed 22 Jan 2014)

Young, A. M. 1982. Effects of Shade Cover and Availability of Midge Breeding Sites on Pollinating Midge Populations and Fruit Set in Two Cocoa Farms. Journal of Applied Ecology 19:47-63. 


\title{
CHAPTER 3
}

\begin{abstract}
Abundance and diversity of shade trees in cacao agroforests (Indonesia) alters vertical rooting patterns and fine root dynamics
\end{abstract}

Yasmin Abou Rajab, Dirk Hölscher, Christoph Leuschner, Henry Barus, Aiyen TuOA, and Dietrich HERTEL 


\subsection{Abstract}

Tropical rainforests are worldwide converted into agricultural land-use systems by a large frequency. While a lot of studies have demonstrated the negative effect of this conversion regarding the loss of biodiversity and ecosystem functions (e.g. carbon sequestration), there is a lack of knowledge about ecosystem functioning of land-use systems differing in their species composition and diversity. This is in particular true for analyses on effects of tree species diversity on vertical root distribution, fine root biomass, productivity and turnover. This study was conducted in Sulawesi, Indonesia, where cacao (Theobroma cacao) is the most important cash crop in order to investigate the influence of shade tree abundance and diversity on vertical rooting patterns and fine root dynamics of cacao and shade trees. We studied three different cacao cultivation systems with different grades of shade tree abundance: non-shaded cacao monoculture, cacao with planted single-shade tree species by Gliricidia sepium and cacao growing under a multi-species shade tree layer. Biomass of fine, large and coarse roots increased with increasing shade tree diversity and abundance and thus, belowground carbon allocation and storage. Standing fine root biomass in the $300 \mathrm{~cm}$ deep profile was more than doubled along the diversity gradient from Cacao-mono to the Cacao-multi stands (206 to $432 \mathrm{~g}$ $\mathrm{m}^{-2}$ ). Highest standing fine root biomass values in the Cacao-mono and the Cacao-Gliricidia sites were located in the upper $20 \mathrm{~cm}$ and decreased with increasing soil depth. In the Cacaomulti stands however, highest standing fine root biomass was located in the subsoil $>100 \mathrm{~cm}$ depth due to high fine root occurrence by shade trees there. The vertical root distribution of cacao was also found to be altered by the presence of shade trees. In the Cacao-Gliricidia sites, vertical root segregation between cacao and Gliricidia roots was apparent. Cacao displayed a shallower root system with clearly highest amounts of fine root biomass in the upper $20 \mathrm{~cm}$, whereas Gliricidia concentrated most of its fine root biomass in the subsoil layers below 100 $\mathrm{cm}$. On the other hand, the presence of various shade trees seemed to induce cacao roots to grow at deeper soil layers. These results were supported by the findings of a deuterium stable isotope analysis which revealed that cacao trees in the Cacao-Gliricidia system obtained water predominantly between 40 and $60 \mathrm{~cm}$ soil depth, while Gliricidia primarily took up water from deeper soil depths. In the Cacao-multi system, we found a clear indication by this approach that cacao and shade trees use the same and deeper soil depth region for soil water uptake. While no significant influence of shade tree abundance and diversity on fine root production could be observed, the presence of a multi-species shade tree layer led to a significant increase in cacao fine root turnover presumably due to a decrease in cacao fine root longevity by a more intense belowground competition with the shade trees.

Keywords: Biodiversity, shade trees, cacao, agroforestry, deuterium, fine root biomass, fine root necromass, fine root production, fine root turnover, vertical root segregation, water uptake 


\subsection{Introduction}

Tropical rainforests are worldwide rapidly converted into more or less intensively managed agricultural land-use systems (e.g. Achard et al. 2002, Hansen et al. 2013). In Indonesia, large areas of tropical rainforest are converted into agricultural cultivation systems (Miettinen et al. 2011, Margono et al. 2014), which makes this country to the current hotspot of rainforest loss worldwide (Lewis et al. 2015). In Sulawesi, where the study took place, these areas are mainly converted into cacao cultivation systems. In the 1980s and 1990s, Sulawesi saw about $50 \%$ of the cacao area emerging in formerly forested areas (Rice and Greenberg 2000). Cacao (Theobroma cacao (L.)) is a crop of the humid tropical lowlands which is mostly cultivated by smallholders. There is still a rising demand of chocolate on the world market (Rice and Greenberg 2000, Bisseleua et al. 2009) which increases the need for additional areas for cacao cultivation. As cacao is an understory rainforest species it was initially planted under natural shade trees (Rice and Greenberg 2000). Nowadays, the natural shade is more and more replaced by planted nitrogen-fixing species like Gliricidia sepium (Jacq.) Kunth, but when the cacao trees mature, shade trees are often completely removed, because farmers fear an aboveand belowground competition between the crop and the shade trees (e.g. Rice and Greenberg 2000, Steffan-Dewenter et al. 2007, Bisseleua et al. 2009, Tscharntke et al. 2011). On the one hand shade trees can enhance nutrient supply by additional $\mathrm{N}$ fixation through legume trees and by enhanced litter fall, root turnover and decomposition (e.g. Beer et al. 1998, Rice and Greenberg 2000, Bisseleua et al. 2009), but on the other hand they might be competing for water and other resources with the crop (Beer 1987). Despite the general importance of roots for competing for water and nutrients, detailed studies about vertical root distribution and root dynamics in tropical land-use systems differing in tree composition are still scarce. Particularly, only little is known so far about the species-specific vertical root pattern, which would allow for assessing possible vertical root segregation among tree species. Since most of the essential nutrients (especially $\mathrm{N}$ and $\mathrm{P}$ ) are predominantly available in the uppermost soil layers (e.g. Varik et al. 2013), competition for those nutrients should be highest in the topsoil. Indeed, several studies reported that the majority of the cacao fine root biomass is located in the uppermost soil (e.g. Kummerow et al. 1982, Nygren and Leblanc 2009, Moser et al. 2010, Nygren et al. 2013), but information about vertical rooting pattern of potential shade tree species is scarce in the literature. Furthermore, there is a lack of information about possible belowground interactions between cacao and shade tree species. Despite the general assumption of apparent belowground competition for water and nutrients between crop and shade trees, different vertical root segregation strategies have been demonstrated in some agroforestry systems in previous studies (Schroth et al. 1996, Lehmann 2003, Ong et al. 2004, Ewel and Mazzarino 2008, Makumba et al. 2009, Moser et al. 2010, Schwendenmann et al. 2010). As a consequence, complementary use of soil water and nutrients could exist, which might minimize interspecific root competition for resources and maximize resource useefficiency in agroforestry systems (Livesley et al. 2000). In an earlier investigation of the same 
study sites Abou Rajab et al. (in revision) showed that cacao bean yield was not negatively influenced by the presence of a diverse shade tree cover although above- and belowground biomass and net primary production increased with increasing shade tree diversity. These results suggest that there must be competition for water rather than for light, therefore calling on more detailed investigations on the rooting pattern of cacao and shade trees in these systems.

The aim of is study thus was to analyze the influence of shade trees on vertical rooting pattern and fine root dynamics of cacao and shade trees in agroforestry systems differing in shade tree abundance and diversity. A replicated comparison was carried out in the Kulawi valley in Central Sulawesi, Indonesia, adjacent to the Lore Lindu National Park, where different cacao cultivation systems with different shade intensities from zero-shade to high shade intensity still co-occur under equal climatic and soil conditions. We investigated standing biomass and vertical distribution of fine ( $<2 \mathrm{~mm}$ diameter), large (2-5 mm diameter), and coarse roots $(>5 \mathrm{~mm}$ diameter) as well as fine root dynamics on species level in monospecific cacao agroforests as compared to cacao plots with planted single-species-shade by the N-fixing legume Gliricidia sepium, and those composed by a multi-species shade tree layer. We explicitly wanted to test the hypotheses that (1) standing fine root biomass increases with increasing shade tree abundance and diversity, that (2) there is vertical root segregation between cacao and shade trees for more effective soil resource exploitation, and that (3) fine root production and turnover increases with increasing shade tree abundance and diversity.

\subsection{Material and Methods}

\section{Study plot selection and study site description}

The study was conducted in the Kulawi valley which is situated in the western margin zone outside the Lore Lindu National Park $\left(01^{\circ} 30^{\prime} \mathrm{S}, 120^{\circ} 02^{\prime} \mathrm{E}\right)$ in Central Sulawesi, Indonesia. Mean annual air temperature is $25^{\circ} \mathrm{C}$ and mean annual precipitation is $2165 \mathrm{~mm} \mathrm{yr}^{-1}$ (Köhler et al. 2014) with no distinct seasonality during the study period. Three different cacao cultivation systems of the following species composition were investigated in this study in order to test the effect of increasing shade tree abundance and diversity on the rooting pattern: (i) monoculture of Theobroma cacao (L.) trees ('Cacao-mono'), (ii) cacao growing with the N-fixing legume tree Gliricidia sepium (Jacq.) Kunth ('Cacao-Gliricidia'), and (iii) cacao cultivated under different shade-tree species ('Cacao-multi'). We selected three study plots of approx. $20 \mathrm{~m} \mathrm{x}$ $20 \mathrm{~m}$ per cultivation system type between the villages Marena and Lempelero in the southern part of the valley. The nine cacao plots studied were very similar in terms of topographic patterns (i.e. of relatively low inclination and aspect), soil morphological (soil type in all sites was Cambic-Umbrisol with slightly varying soil texture), and soil chemical properties (Abou Rajab et al., in revision). Thus, $\mathrm{pH}$ values, exchange capacity, base cation availability, and $\mathrm{C} / \mathrm{N}$ ratios were measured to be quite comparable across the 9 study plots (Appendix Table A3.1). 
An aboveground stand structure inventory was conducted in all nine study plots at the beginning of the study in summer 2011, where canopy cover, tree- and stem density, stand basal area and stem diameter as well as tree height and the diversity of the woody species using the Shannon-Wiener's H' were measured (Appendix Table A2). Accordingly, canopy cover, tree- and stem density, stand basal area, stem diameter and tree height as well as Shannon index increased in the sequence Cacao-mono - Cacao-Gliricidia - Cacao-multi (Appendix Table A3.2). Shade trees of various species in the Cacao-multi treatment were much higher than cacao and Gliricidia trees, had a much larger stem diameter and therefore contributed to a higher stand basal area of the shade trees although these trees counted only for a minor proportion of the tree density in these plots (Abou Rajab et al., in revision). In all shaded plots a significantly higher stem and tree density of cacao trees as compared to the number of shade trees was apparent, and cacao and shade trees within the cultivation systems differed significantly in almost every term except of stem diameter in the Cacao-Gliricidia treatment. However, stem diameter of cacao trees was significantly higher when growing in monoculture than under Gliricidia shade tree cover but only slightly higher than under multiple shade tree cover. Results from an earlier study of the same plots revealed that total above-ground biomass increased strongly with increasing shade tree diversity ranging from ca. $23 \mathrm{Mg} \mathrm{ha}^{-1}$ in monoculture to over $40 \mathrm{Mg} \mathrm{ha}^{-1}$ in the Cacao-Gliricidia plantations to $124 \mathrm{Mg}$ $\mathrm{ha}^{-1}$ in Cacao-multi systems (data not shown). The biomass contributed by the cacao trees was somewhat lower in the Cacao-Gliricidia stands but highest in the Cacao-multi sites. Total aboveground net primary production increased likewise with the same sequence. CacaoGliricidia plots had already around one third higher total NPP than cacao monocultures (28 vs. $20 \mathrm{Mg} \mathrm{ha}^{-1} \mathrm{yr}^{-1}$ ), while Cacao-multi stands had a nearly two times higher total NPP (i.e. $38 \mathrm{Mg}$ $\mathrm{ha}^{-1} \mathrm{yr}^{-1}$ ) compared to Cacao-mono stands (data not shown). In contrast, cacao yield was not significantly different between the three cultivations systems (data not shown).

\section{Standing fine root mass and vertical root distribution}

For recording the standing fine root mass abundance in the upper, densely rooted soil twelve soil samples randomly distributed over the whole plot area were taken at each study site with a soil core $(3.5 \mathrm{~cm}$ in diameter) down to a depth of $60 \mathrm{~cm}$. Each of the soil cores was divided into four subsamples of $0-10,10-20,20-40$, and 40-60 cm soil depth. The soil samples were transferred to plastic bags, transported to the laboratory of the Tadulako University of Palu, and stored in the fridge at $4^{\circ} \mathrm{C}$ until they were processed.

In the laboratory, the root samples were soaked in water and cleaned of soil residues using a sieve with a mesh size of $0.25 \mathrm{~mm}$. Large root fractions (>10 $\mathrm{mm}$ in length) were picked out manually and separated into fine roots (roots $<2 \mathrm{~mm}$ in diameter), large roots (roots $2-5 \mathrm{~mm}$ in diameter), and coarse roots (roots $>5 \mathrm{~mm}$ in diameter). Living and dead rootlets were distinguished under the stereomicroscope by color, root elasticity, and the degree of cohesion of cortex, periderm, and stele following the method by Leuschner et al. (2001) and Hertel and Leuschner (2002). All root individuals were assigned to the cacao or shade tree species 
present in the respective study plots by means of morphological characteristics. Rootlets traced back from the stem of each species present on or near the study plot were studied and analyzed under the stereomicroscope prior to our main soil sampling. The most frequently tree species present in the plots were Aleurites moluccana (L.) Willd., Ceiba pentandra (L.) Gaertn., Durio zibethinus (L.), Gliricidia sepium, Leucaena leucocephala (Lam.) de Wit, Pterocarpus indicus Willd., and Theobroma cacao L.. For half of the samples an additional detailed analysis of smallest fine root particles ( $<10 \mathrm{~mm}$ in length) was conducted applying a method introduced by van Praag et al. (1988) and modified by Hertel and Leuschner (2002). The soil samples were cleaned using a finer sieve with a mesh size of $200 \mu \mathrm{m}$ and after extraction of the large root fractions the residue of the sample was evenly spread on a large sheet of filter paper $\left(730 \mathrm{~cm}^{2}\right)$ with 36 squares marked on it. Six of the squares were randomly selected and analyzed under the stereomicroscope for even smallest fine root fragments. The mass of small rootlets was extrapolated to the entire sample by a regression analysis of small rootlets to large rootlets. All root material was dried at $70^{\circ} \mathrm{C}$ for 48 hours until constant weight.

In order to analyze the soil profile totals of fine, large and coarse root biomass and their vertical root distribution pattern down to a soil depth of $300 \mathrm{~cm}$, soil pits were excavated at each study site. In the cultivation systems of cacao monoculture two soil pits ca. $80 \mathrm{~cm}$ far from randomly selected cacao trees were excavated (which was found to represent roughly half of the average stem distance in the agroforestry systems). In case of shaded cacao agroforests, two soil pits from each two cacao trees and two randomly selected shade trees were excavated. Root biomass was recorded by extracting soil monoliths of a size of $30 \mathrm{~cm} \mathrm{x} 30 \mathrm{~cm}$ ground area and of $20 \mathrm{~cm}$ depth down to $120 \mathrm{~cm}$ in the soil profile and of $40 \mathrm{~cm}$ depth from 120 to 300 $\mathrm{cm}$ in the soil profile, respectively. The soil monoliths were sieved (mesh size $2 \mathrm{~mm}$ ) directly in the field and the root material was transferred to plastic bags and transported to the laboratory of the Tadulako University of Palu, where they were sorted into species and the different root diameter classes as described above.

Roots of grasses and herbs were easily distinguishable from tree fine roots by their smaller diameter, lighter color and the absence of a lignified periderm. For the analysis of root biomass only tree roots were considered, because in all study sites the proportion of herbs and grasses was below 5\%. In some study sites roots of tree species not growing inside the plots, but entering the plot soil from outside or origin from dead tree stumps of former shade trees were found. Mainly, these did not account for a larger percentage (an exception was plot \#1, plot \#2 and plot \#5, were these roots accounted for a larger percentage). For the analysis of standing fine root biomass, roots of trees growing outside the study site or apparently dead tree stumps of former shade trees were included.

Profile totals of standing fine, large, and coarse root biomass was calculated from both the root inventory in the upper soil and the data from the deep soil pits in each of the study plots. An exception was plot \#6, where the soil pits could only be excavated to a depth of $100 \mathrm{~cm}$ due to water entrance to the soil pits through persistent rainfall events during the field campaign. In 
this special case we used the mean root biomass values from $100-300 \mathrm{~cm}$ from the other two study sites of the same cultivation system (plots \#4 and \#5) to calculate the fine root biomass totals for the entire soil profile for this plot. The data from the deep soil pits were not only used to analyze the vertical root distribution pattern depending from species identity and cultivation system, but also to assess the mean maximum and absolute maximum rooting depth of fine, large and coarse roots for cacao trees and frequently occurring and representative shade tree species. Mean maximum rooting depth for each species was calculated from the corresponding soil pit whereas absolute maximum rooting depth per species was taken from all soil pits of a study site. Furthermore, we calculated the cumulative vertical root biomass distribution pattern for fine and large roots after Gale and Grigal (1987) individually for all most frequently occurring tree species (Leuschner et al. 2006, Hertel et al. 2007, Gaul et al. 2008). The steepness of the cumulative fine root biomass decrease with depth is expressed by the $\beta$ value of the regression equation $\mathrm{y}=1-\beta^{d}$, with y being the cumulative root biomass fraction in $\mathrm{g} \mathrm{m}^{-2}$ and $d$ being the soil depth in $\mathrm{cm}$. High $\beta$ values indicate a large proportion of root biomass in a deeper soil depth, whereas low values indicate a large proportion of the respective roots near the soil surface.

\section{Fine root morphology}

In order to study fine root morphological patterns, one to two living fine roots per tree species of each sample and soil depth from the fine root biomass sampling were scanned and the pictures were analyzed for mean root diameter, root surface area specific root length using the computer software WinRhizo 2002a (Régent, Quebec, Canada). Specific fine root surface area (SRA, in $\mathrm{cm}^{2} \mathrm{~g}^{-1}$ ) and specific root length (SRL, in $\mathrm{cm}^{2} \mathrm{~g}^{-1}$ ) were calculated from the dry weight of the respective root individuals.

\section{Fine root production and turnover}

Fine root production in the different cultivation systems was estimated by conducting an ingrowth core experiment with local soil material according to the methodology described by Persson (1980), and Hertel and Leuschner (2002). At 10 randomly chosen locations in each of the nine stands, soil cores were taken $(3.5 \mathrm{~cm}$ in diameter) from the first $30 \mathrm{~cm}$ of the soil. All macroscopically visible living and dead root material was extracted manually directly in the field. The remaining soil material was replaced into the hole and marked with plastic tubes. Care was taken that the structure and density of the soil samples were conserved as much as possible. The samples were recollected with the same soil corer after 10 months, where each soil core was divided into two vertically distributed subsamples (0-10 and 10-30 cm depth). In the laboratory of the University in Palu, root biomass was extracted as described above. Following Vogt et al. (1998), and Hertel and Leuschner (2002), we calculated fine root production in the cores as the increase in root biomass from the start of root recolonisation (in our study 1 month after installation, see also Harteveld et al. 2007) until harvest. Fine root 
growth in the cores during the recolonisation period was extrapolated to one year and expressed in $\mathrm{g} \mathrm{m}^{-2} \mathrm{yr}^{-1}$.

Fine root turnover $\left(\right.$ year $^{-1}$ ) in the ingrowth cores was calculated as annual fine root growth divided by the standing fine root biomass in the same soil depths (Aber et al. 1985, Aerts et al. 1992) by relating the fine root growth recorded in the ingrowth cores after a 1-year growth period to the fine root biomass observed in the fine root inventory. We extrapolated the data to $60 \mathrm{~cm}$ soil depth assuming the same fine root turnover rate from 10-30 cm depth valid for the standing fine root biomass present in $30-60 \mathrm{~cm}$ soil depth.

\section{Analysis of differences in soil depth of preferential water uptake}

We applied a natural Deuterium abundance approach in order to detect differences in the depth of preferential soil water uptake. Stem samples were taken in a Cacao-Gliricidia stand and in a stand with a multi-species tree assemblage from 16 trees using a stem corer (Haglöf, Långsele, Sweden) in October 2011. Soil samples were taken from 5 soil depth intervals (0-10, 10-20, 20-40, 40-60 and 60-100 cm) underneath the respective trees. Prior to sampling, there were 8 rainless days with relatively high evaporative demand. Water was extracted from the samples using the cryogenic vacuum extraction method (Ehleringer and Osmond 1989, West et al. 2006) at $\sim 115^{\circ} \mathrm{C}$ and 0.01 mbar. Before sample extraction, we tested the effect of different extraction times $(60,90,180$ and 240 minutes) on the isotopic composition of water extracts in order to determine the time required to obtain unfractionated water samples (West et al. 2006). Our results showed that an extraction time of 90 minutes is necessary to obtain unfractionated water samples, which is substantially longer than the times given by West et al. (2006). After the cryogenic extraction, samples were oven-dried at $110^{\circ} \mathrm{C}$ for 72 hours and stored for further analysis. Measurements of $\delta^{2} \mathrm{H}$ and $\delta^{18} \mathrm{O}$ isotopic composition were conducted on a high temperature conversion elemental analyzer (TC/EA, Thermo Electron Corporation, Bremen, Germany) coupled to a Delta V Plus isotope ratio mass spectrometer (Thermo Electron Corporation) with reversed sample flow giving a measurement precision of $\pm 2 \%$ for $\delta^{2} \mathrm{H}$ and $\pm 0.2 \%$ for $\delta^{18} \mathrm{O}$, respectively.

\section{Statistical analyses}

All data were tested for Gaussian distribution using a Shapiro-Wilk test. The majority of the datasets showed a non-Gaussian distribution and could not be transformed. Thus, differences between the cultivation systems and the tree groups were analyzed for all parameters using non-parametric analyses of variance (Kruskal-Wallis $\mathrm{H}$ test) and a subsequent Mann-Whitney two-sample test (Wilcoxon U test). These calculations as well as Pearson correlation analyses were done with the software package SAS 9.3 (version 9.3, SAS Institute, Cary, NC, USA). Regression analyses were conducted with the software package Xact7 (Sci Lab, Hamburg, Germany). For analyzing interrelations between tree species diversity, stand structure, carbon sequestration and cacao bean yield, we conducted a Principle Components Analysis (PCA) with the package CANOCO, version 4.5 (Biometris, Wageningen, The Netherlands). 


\subsection{Results}

\section{Standing fine root biomass and necromass}

Standing fine root biomass totals $(0-300 \mathrm{~cm}$ soil depth) is markedly increasing with increasing shade tree cover (though only marginally significant) (Fig. 3.1a). In Cacao-mono plots, mean standing fine root biomass was $206.4 \mathrm{~g} \mathrm{~m}^{-2}$, while it accounted for $301.4 \mathrm{~g} \mathrm{~m}^{-2}$ in CacaoGliricidia and $431.8 \mathrm{~g} \mathrm{~m}^{-2}$ in Cacao-multi stands, respectively. There are differences in fine root distribution in the distinct soil depths between and within the three cultivation types (Fig. 3.1a). In Cacao-mono, the major part of the fine root biomass was located in the upper $20 \mathrm{~cm}$, while fine root mass was less abundant in the deeper soil depths, where they were more or less equally distributed. In the Cacao-Gliricidia plots, the vertical distribution pattern was similar than in the Cacao-mono stands. However, fine root biomass in the lowermost soil depth (100-300 cm) was significantly higher than in the monocultures (Fig. 3.1a). The coincidence of the presence of shade tree individuals and an increasing abundance of fine root biomass in deeper soil depths was even more pronounced in the Cacao-multi agroforests, where high amounts of fine root biomass was present in the uppermost soil depth $(0-20 \mathrm{~cm})$, but fine root biomass abundance was also high in 60-100 cm depth and even highest in 100$300 \mathrm{~cm}$ depth (Fig. 3.1a). 

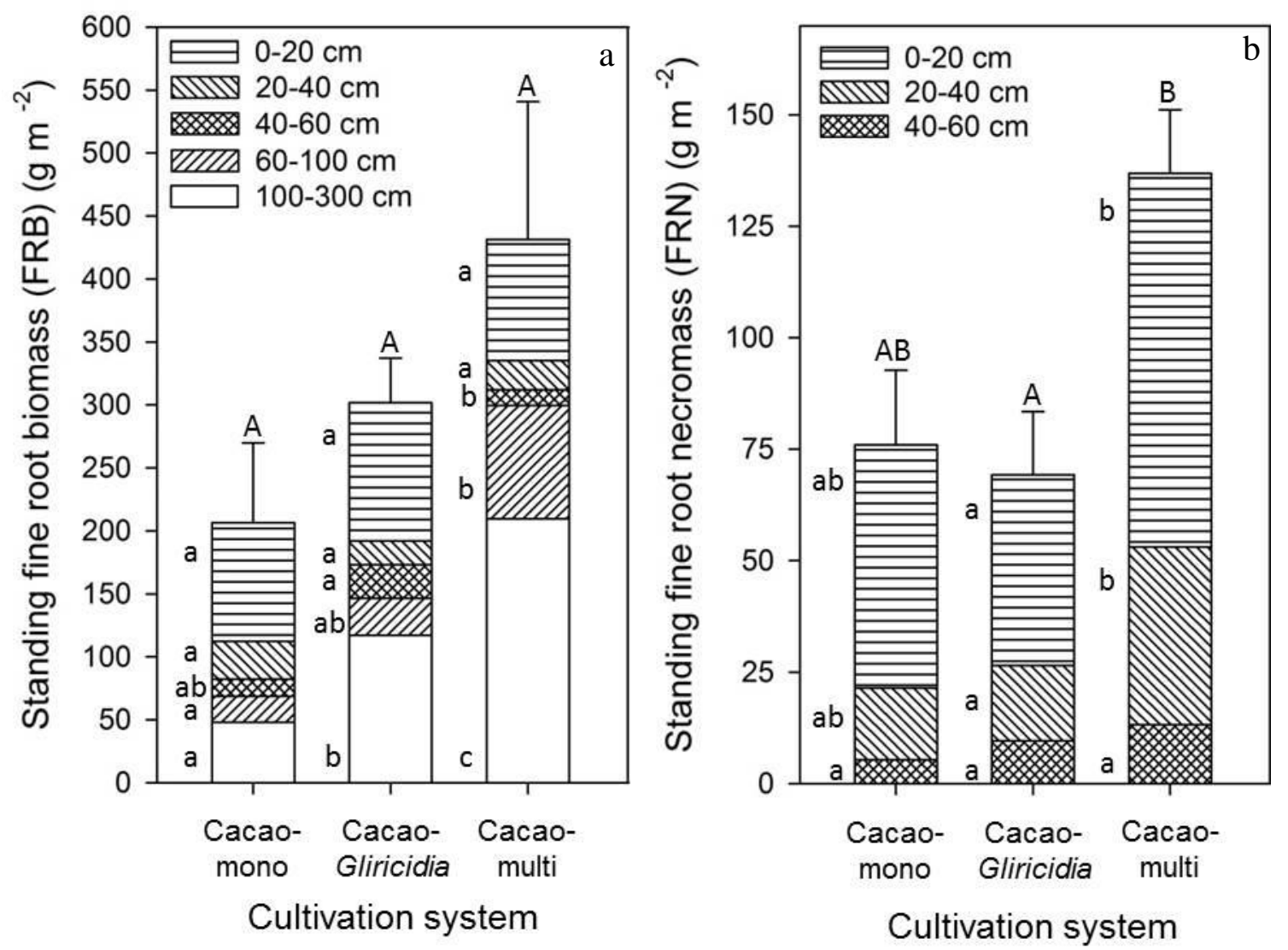

Figure 3.1: Standing fine root biomass (a) in the different cacao cultivation systems in the Kulawi valley (Sulawesi, Indonesia) from 0-300 cm depth, shown in 5 soil depths $(0-20,20-40,40-60,60-100$ and $100-300 \mathrm{~cm}$ ) and the total profile. Standing fine root necromass (b) in the different cacao cultivation systems from $060 \mathrm{~cm}$ depth, shown in 3 soil depths $(0-20,20-40$, and $40-60 \mathrm{~cm})$ and the total profile. Different capital letters indicate statistically significant differences between the agroforestry systems; lower case letters indicate statistically significant differences in the respective soil depth between the cultivation systems $(\mathrm{p}<0.05)$.

Standing fine root necromass total $(0-60 \mathrm{~cm}$ soil depth) was markedly higher in the Cacaomulti systems with approx. $138 \mathrm{~g} \mathrm{~m}^{-2}$ compared to the less diverse systems with $65 \mathrm{~g} \mathrm{~m}^{-2}$ and $62 \mathrm{~g} \mathrm{~m}^{-2}$ in cacao monoculture and Cacao-Gliricidia stands, respectively (Fig. 3.1b). Highest fine root necromass was accumulated in the top $20 \mathrm{~cm}$ of the soil in all three cultivation systems and decreased with increasing soil depth. In the two deeper soil layers $(20-40 \mathrm{~cm}$ and 40-60 cm, respectively) fine root necromass increased with increasing shade tree diversity (Fig. 3.1b). Fine root necromass of cacao trees from $0-60 \mathrm{~cm}$ slightly decreased with increasing shade tree diversity as well as with soil depth (see Appendix Table A3.3). Likewise to cacao fine roots, necromass of shade trees decreased with soil depths in the CacaoGliricidia system, but increased in the Cacao-multi stands.

When comparing the ratio of living:dead fine root mass, we calculated highest ratios of the soil profile for 0-60 cm for Cacao-Gliricidia stands with 2.2 and lowest for Cacao-multi stands with 1.0 (Table 3.1). Cacao monocultures lay in between with a ratio of 1.8. For the uppermost in the soil depth $(0-20 \mathrm{~cm})$, the Cacao-Gliricidia system had significantly highest living:dead fine root mass ratios compared to the Cacao-mono and the Cacao-multi sites, and 
the same was true for the soil depth $40-60 \mathrm{~cm}$, but the latter trend was not statistically significant (Table 3.1).

Table 3.1: Ratio of fine root biomass (FRB) to fine root necromass (FRN) in the different cacao cultivation systems in the Kulawi valley (Sulawesi, Indonesia) from 0-60 cm depth, shown in 3 soil depths $(0-20 \mathrm{~cm}, 20-40 \mathrm{~cm}, 40-60 \mathrm{~cm}$, and the total profile $(0-60 \mathrm{~cm})$. Capital letters indicate statistically significant differences between the agroforestry systems; lower case letters indicate statistically significant differences of the different soil depths between the cultivation systems $(p<$ $0.05)$.

\begin{tabular}{lrl} 
Cultivation system & depth $(\mathrm{cm})$ & $\begin{array}{l}\text { living/dead fine } \\
\text { root mass ratio }\end{array}$ \\
& & \\
\hline \multirow{2}{*}{ Cacao-mono } & $0-20$ & $1.7 \pm 0.4 \mathrm{a}$ \\
& $20-40$ & $2.0 \pm 0.8 \mathrm{a}$ \\
$40-60$ & $2.2 \pm 0.9 \mathrm{a}$ \\
& $0-60$ & $1.8 \pm 0.4 \mathrm{AB}$ \\
& & \\
Cacao-Gliricidia & $0-20$ & $2.5 \pm 0.2 \mathrm{~b}$ \\
& $20-40$ & $1.2 \pm 0.3 \mathrm{a}$ \\
& $40-60$ & $6.5 \pm 4.4 \mathrm{a}$ \\
& $0-60$ & $2.2 \pm 0.2 \mathrm{~A}$ \\
& $0-20$ & $1.2 \pm 0.4 \mathrm{a}$ \\
Cacao-multi & $20-40$ & $0.7 \pm 0.2 \mathrm{a}$ \\
& $40-60$ & $1.4 \pm 0.8 \mathrm{a}$ \\
$0-60$ & $1.0 \pm 0.4 \mathrm{~B}$ \\
\hline
\end{tabular}

Comparison of the abundance of fine $(\mathrm{d}<2 \mathrm{~mm})$, large $(\mathrm{d}=2-5 \mathrm{~mm})$ and coarse $(\mathrm{d}>5 \mathrm{~mm})$ root biomass in the soil profile of the three cacao agroforestry systems showed that the three root diameter groups did not coincide in their vertical rooting pattern (Table 3.2). The majority of the fine root biomass of cacao trees was located in the uppermost $20 \mathrm{~cm}$ in all three cultivation systems. The same was true for the large roots of cacao, but cacao coarse roots were more evenly distributed in the Cacao-mono and Cacao- Gliricidia stands throughout the first $100 \mathrm{~cm}$ of the soil while the largest biomass of cacao coarse roots were found in the lowermost soil depth $(100-300 \mathrm{~cm})$ in the Cacao-multi systems (Table 3.2). Fine roots of Gliricidia shade trees in the Cacao-Gliricidia plots were less abundant compared to the co-occurring cacao fine roots and showed an increase in vertical root distribution with soil depth. Large roots of Gliricidia trees, in contrast, were more concentrated in the uppermost soil depths and Gliricidia coarse roots revealed a similar vertical rooting pattern as the large roots, but were not present in the uppermost soil. In the Cacao-multi systems, fine roots of the shade tree species dominated over that from cacao in all soil depths. Shade tree fine root biomass was highest in the uppermost soil, but was found in notable abundance in all soil depths of the whole soil profile as well. The same was true for the large roots of the shade tree 
species in these agroforestry systems. In contrast to the cacao trees, coarse root biomass of cooccurring shade trees was high in uppermost soil depth, but was high as well in the soil profile from $60 \mathrm{~cm}$ down to $300 \mathrm{~cm}$ (Table 3.2).

Table 3.2: Biomass of fine roots $(\mathrm{d}<2 \mathrm{~mm})$, large roots $(\mathrm{d}=2-5 \mathrm{~mm})$ and coarse roots $(\mathrm{d}>5 \mathrm{~mm})$ of cacao trees and shade trees in the different soil depths of the three cacao agroforestry systems in the Kulawi valley (Sulawesi, Indonesia). The percentage proportion of the profile's total in a given soil depth is given in brackets. Different capital letters indicate statistically significant differences between the agroforestry systems; lower case Latin letters indicate statistically significant differences of the different soil depths between the cultivation systems and lower case Greek letters indicate statistically significant differences between cacao and shade trees within a cultivation system $(p<0.05)$.

\begin{tabular}{|c|c|c|c|c|c|c|c|c|c|c|}
\hline 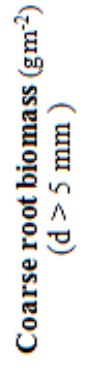 & 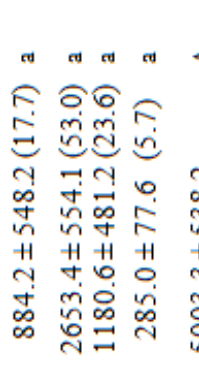 & 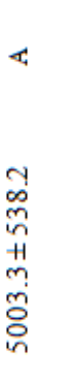 & 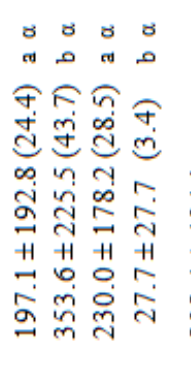 & $\begin{array}{l}7 \\
7 \\
+ \\
+ \\
+1 \\
+1 \\
+ \\
0 \\
0 \\
0\end{array}$ & 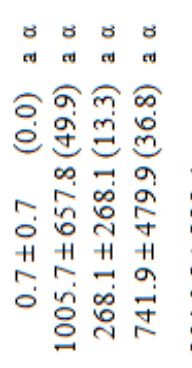 & 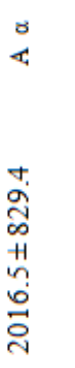 & 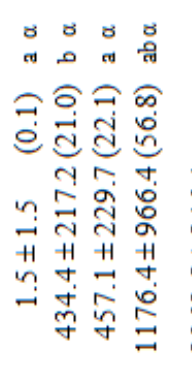 & 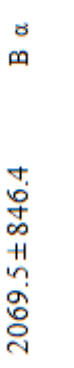 & 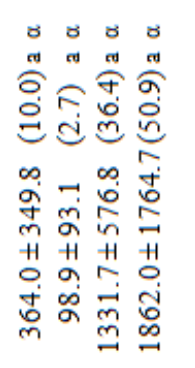 & 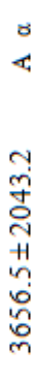 \\
\hline 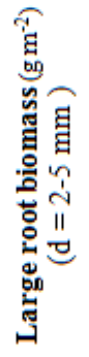 & 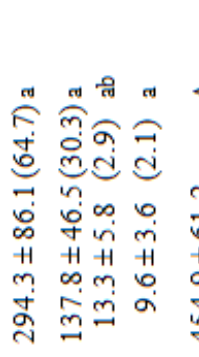 & 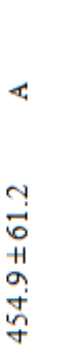 & 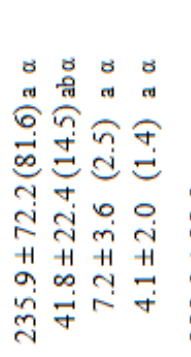 & $\begin{array}{l}0 \\
4 \\
\\
m \\
\infty \\
\infty \\
+1 \\
0 \\
0 \\
\infty \\
\infty\end{array}$ & 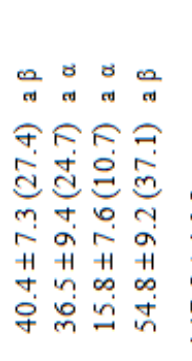 & 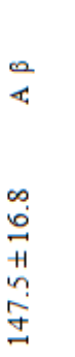 & 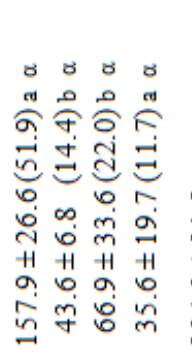 & $\begin{array}{l}0 \\
4 \\
\\
\infty \\
-1 \\
m \\
+1 \\
0 \\
0 \\
\dot{1} \\
\dot{m}\end{array}$ & 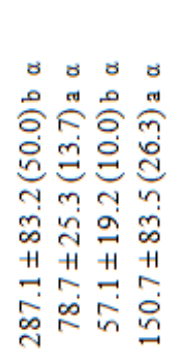 & 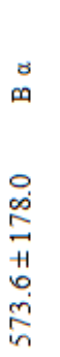 \\
\hline 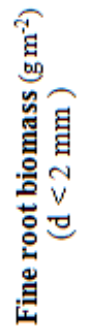 & 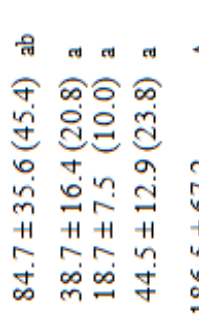 & 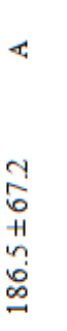 & 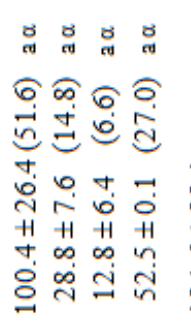 & 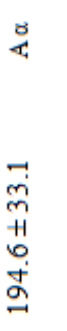 & 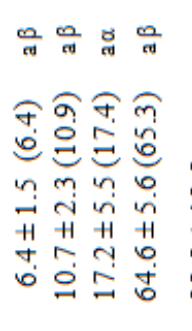 & $\begin{array}{l} \\
\infty \\
\text { d } \\
\text { 1 } \\
\infty \\
\infty \\
\infty \\
\infty\end{array}$ & 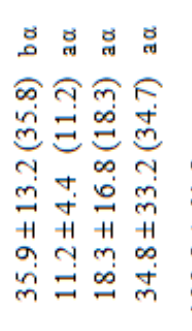 & 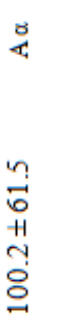 & 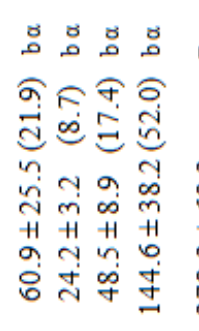 & 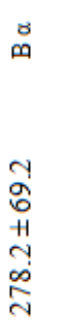 \\
\hline 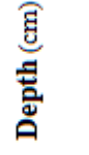 & 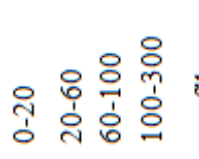 & 䓌 & 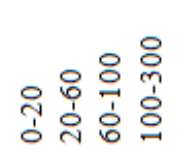 & 壱 & 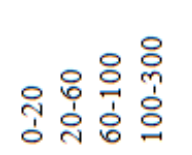 & $\begin{array}{l}\text { 泀 } \\
\text { 品 }\end{array}$ & 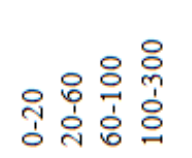 & 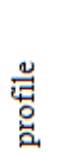 & 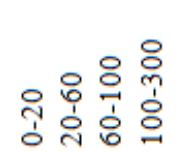 & 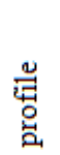 \\
\hline 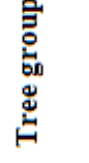 & $\begin{array}{l}\text { ల్ల } \\
\text { U్ }\end{array}$ & & 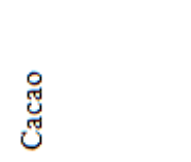 & & 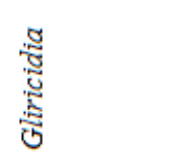 & & ల్ల & & $\begin{array}{l}\text { 莺 } \\
\text { ज् }\end{array}$ & \\
\hline 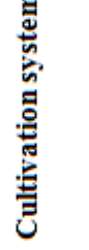 & 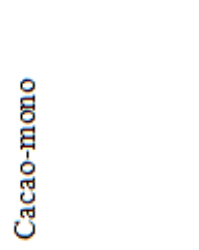 & & 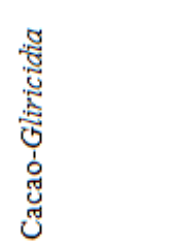 & & & & 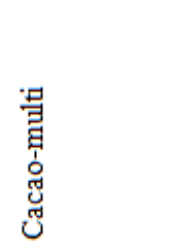 & & & \\
\hline
\end{tabular}


Vertical distribution in volumetric root density of the agroforestry species

The vertical pattern of volumetric root density of cacao fine and large roots differed in the Cacao-mono system in the way that the vertical large root pattern was much more superficial compared to that of fine roots (Fig. 3.2). This is also shown in the different $\beta$ values calculated for describing the cumulative vertical rooting pattern that was 0.98 for cacao fine roots, but 0.95 for large roots (Table 3.3). A similar pattern was found for cacao fine and large roots in the Cacao-Gliricidia cultivation systems with a less steep decrease of density of fine roots ( $\beta$ value 0.98 ) with soil depth compared to large roots ( $\beta$ value 0.93 ) (Fig. 3.2, Table 3.3). The co-occurring shade tree species Gliricidia had a less high concentration of fine and large roots in the uppermost soil depth than cacao tees, but tended to have higher fine and large root densities in the middle and deeper soil depths than cacao trees in this system $(\beta$ values of 0.99 for both root diameters). In the Cacao-multi systems, vertical pattern of cacao fine and large root densities was less superficial compared to that in the Cacao-mono and Cacao-Gliricidia plots (Fig. 3.2, Table 3.3). The vertical rooting pattern of cacao fine roots was very similar to that of the five co-occurring shade tree species investigated with all six species showing notable fine root densities not only in the uppermost, but as well in middle and low soil depths. For large roots, the vertical distribution in cacao and the shade tree species was more variable. While Durio zibethinus, Ceiba pentandra and Aleurites moluccana showed a quite strong decrease in large root density with soil depth, Pterocarpus indicus and Leucaena leucocephala showed notable peaks of large root density in middle or deeper soil depth; cacao trees sowed a vertical large root pattern that lay between that of these two groups of shade trees (Fig. 3.2, Table 3.3). 

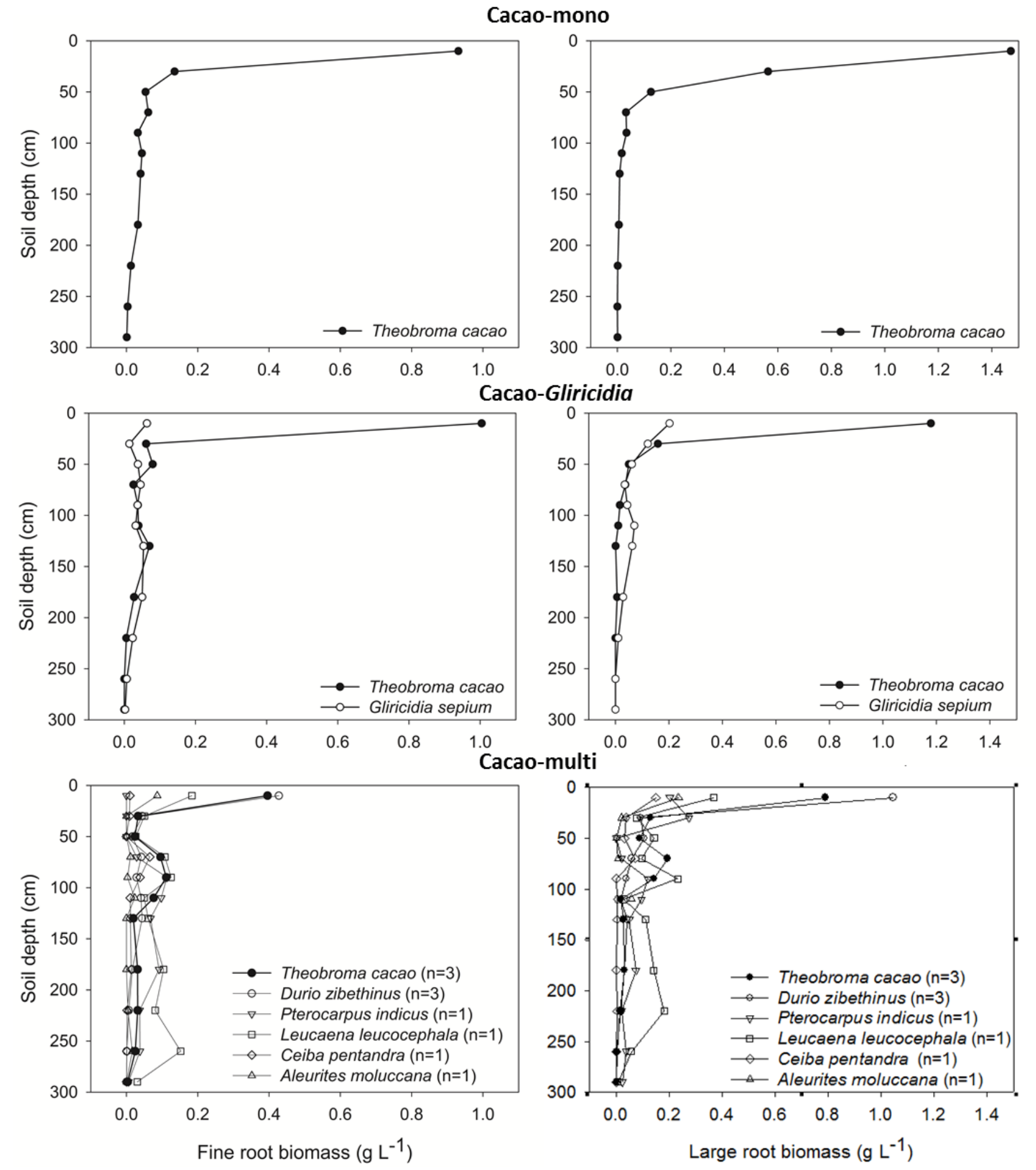

Figure 3.2: Vertical root distribution of fine and large roots of Theobroma cacao, Gliricidia sepium and five other representative shade tree species in the different cacao cultivation systems in the Kulawi valley (Sulawesi, Indonesia); ( $\mathrm{n}=$ number of plots). 


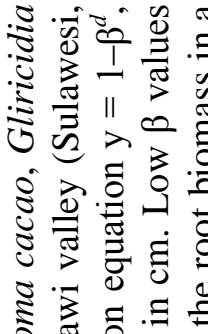

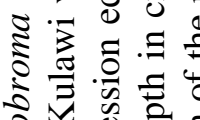

ฆั

F $0 \overline{0}$

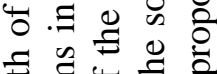

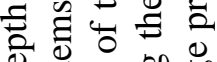

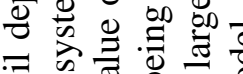

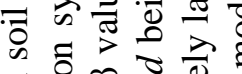

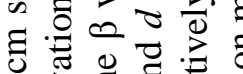

$8 . \geqq \Xi$ च

$\begin{array}{llll}0 & 0 & 0 & 0 \\ 0 & 0 & 0 & 0 \\ 0 & 0 & 0 & 0\end{array}$

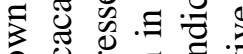

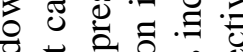

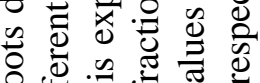

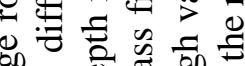

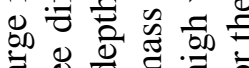

혀 웧

혀

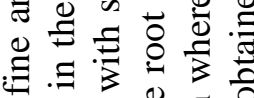

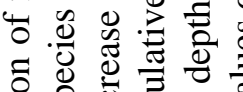

ธี

更 0

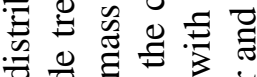

i :

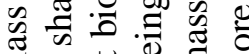

¿

음 공 궁

퓨욜

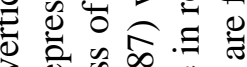

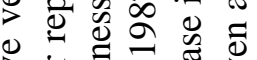

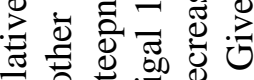

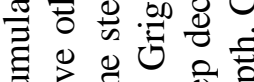

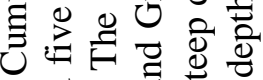

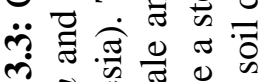

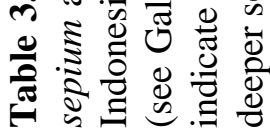

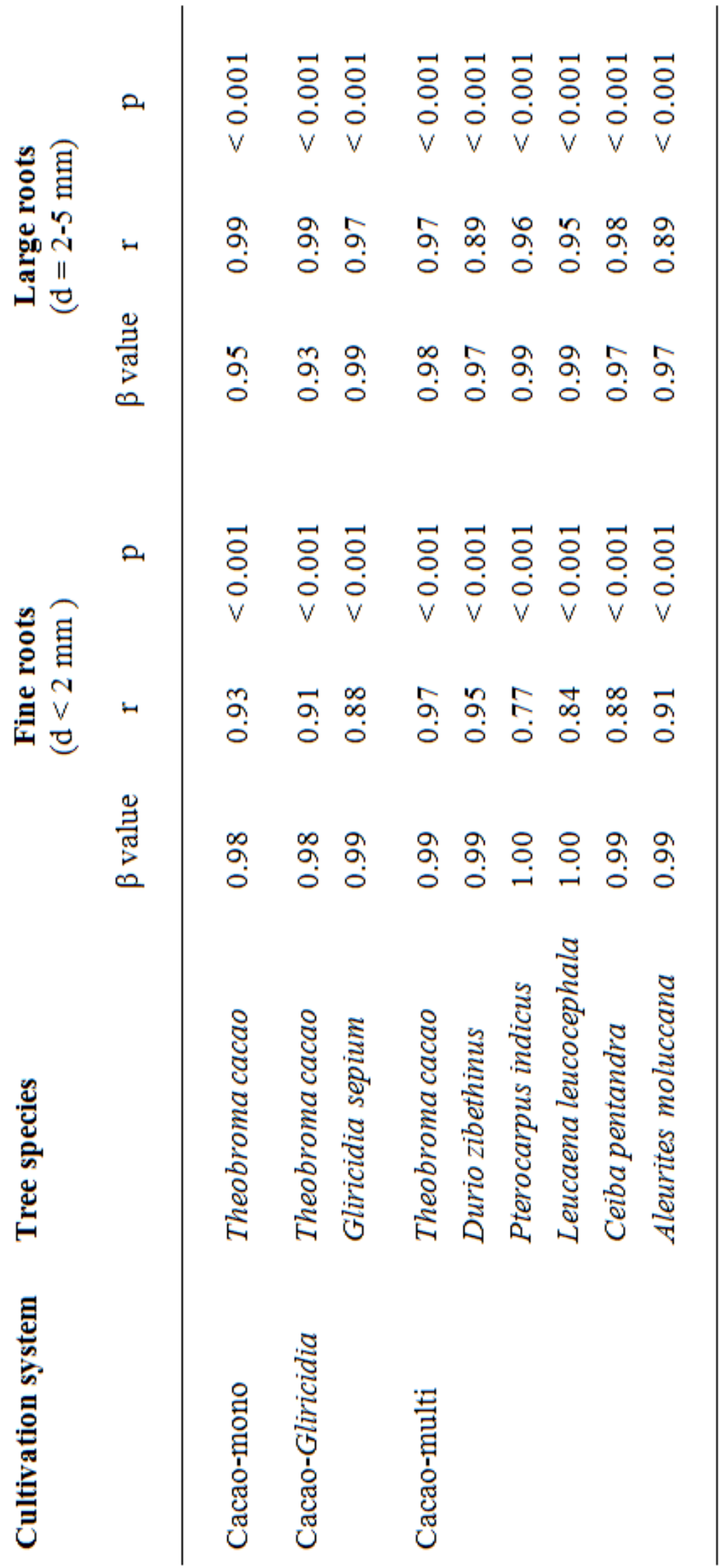


Presence of 'deep roots' of cacao and shade tree species

For an inventory of 'deep roots', defined as roots present in soil depths $>100 \mathrm{~cm}$ (Nepstad et al. 1994, Canadell et al. 1996, Akinnifesi et al. 2004) of cacao and six shade tree species in the different cultivation systems, an analysis of mean maximum and absolute maximum depth of fine, large and coarse roots in the $300 \mathrm{~cm}$ deep soil profiles was conducted. Absolute maximum rooting depth of cacao fine roots was $300 \mathrm{~cm}$ in all three cacao agroforestry types (Table 3.4). Mean maximum rooting depth of cacao fine roots in the three cultivation systems was high as well $(260-280 \mathrm{~cm})$ and tended to increase slightly with increasing shade tree diversity and abundance. Mean maximum rooting depth of cacao large roots was less high than in fine roots and differed not systematically between the three cacao agroforestry systems (c. 130-170 cm). Mean maximum rooting depth in cacao coarse roots was much lower than that of fine and large roots: while it was 43 and $30 \mathrm{~cm}$ in the Cacao-mono and Cacao-Gliricidia plots, respectively, this diameter class reached a mean maximum rooting depth of $87 \mathrm{~cm}$ in the Cacao-multi plots (Table 3.4). This pattern was even more pronounced considering the absolute maximum rooting depth of cacao coarse roots that was only 80 and $60 \mathrm{~cm}$ in the Cacao-mono and Cacao-Gliricidia plots, but reached down to the deepest soil depth $(300 \mathrm{~cm})$ in the Cacao-multi plots. In the Cacao-Gliricidia system, Gliricidia fine, large and coarse roots revealed a 'deep root' pattern similar to the cacao root system, but had a slightly (though statistically significant) mean maximum fine root depth and a markedly higher mean maximum large root depth than co-occurring cacao roots. In the Cacao-multi plots, overall, absolute maximum rooting depth of the shade tree species of fine, large and coarse roots was very similar to that of cacao roots. However, while the mean maximum rooting depth of fine roots of the shade trees was similar as well to that of cacao fine roots, shade trees had much deeper mean maximum rooting depths of large and coarse roots than cacao trees (though statistically not significant: $\mathrm{P}=0.13$ and $\mathrm{P}=0.19$, respectively). When looking at the maximum rooting depth of the five most abundant shade trees species separately, a large variation in this pattern was observed. Due to the large variation in abundance of trees of the different species in the plots, only absolute maximum rooting depths are available for these species (except the most abundant shade tree species Durio zibethinus). Accordingly, fine roots of all species except Ceiba petandra reached down to the entire 300 $\mathrm{cm}$ deep soil profiles (Table 3.4). Similarly, large roots of four of the six shade tree species showed a very high absolute maximum rooting depth $(240-300 \mathrm{~cm})$, while large roots of Aleurites moluccana and Ceiba petandra were found only down to a soil depth of $120 \mathrm{~cm}$. Even more heterogeneous was the absolute rooting depth of coarse roots of the shade tree species with three species showing very deep absolute maximum rooting depth $(280 \mathrm{~cm})$, one species showing a moderately deep maximum rooting depth $(200 \mathrm{~cm})$, and two species with very superficial maximum rooting depth of the coarse roots $(20-40 \mathrm{~cm})$ (Table 3.4). 


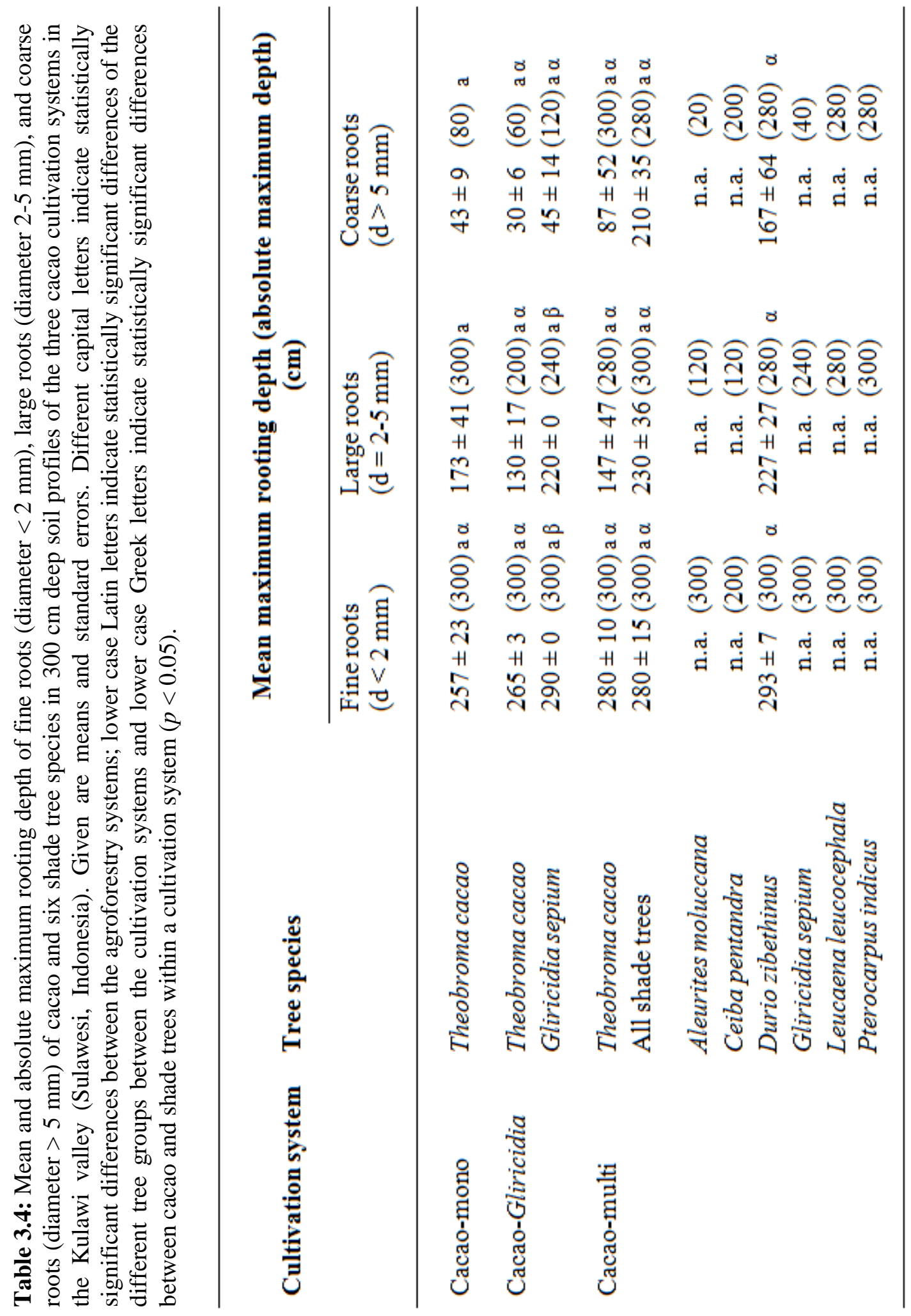


Fine root production and turnover

Fine root production was surprisingly similar comparing the three cacao agroforestry systems (Fig. 3.3). Considering fine root production of all tree species present in the systems, a range of 153 to $191 \mathrm{~g} \mathrm{~m}^{-2} \mathrm{yr}^{-1}$ was found across the three cultivation systems for the soil profile down to $60 \mathrm{~cm}$ depth. Annual production of cacao fine roots in the total soil profile was highest in the Cacao-mono plots $\left(167 \mathrm{~g} \mathrm{~m}^{-2} \mathrm{yr}^{-1}\right)$ and decreased slightly with increasing shade tree abundance and diversity (133 and $113 \mathrm{~g} \mathrm{~m}^{-2} \mathrm{yr}^{-1}$, respectively). Shade tree species in both the Cacao-Gliricidia and the Cacao-multi plots had on average a significantly lower annual fine root production as compared to cacao trees (Fig. 3.3). For both, cacao and shade tree species, fine root production was similarly high or even higher in 10-30 cm soil depth than in the uppermost $10 \mathrm{~cm}$ of the soil. In the Cacao-Gliricidia system, fine root production of the Gliricidia trees was even highest in 30-60 cm soil depth.

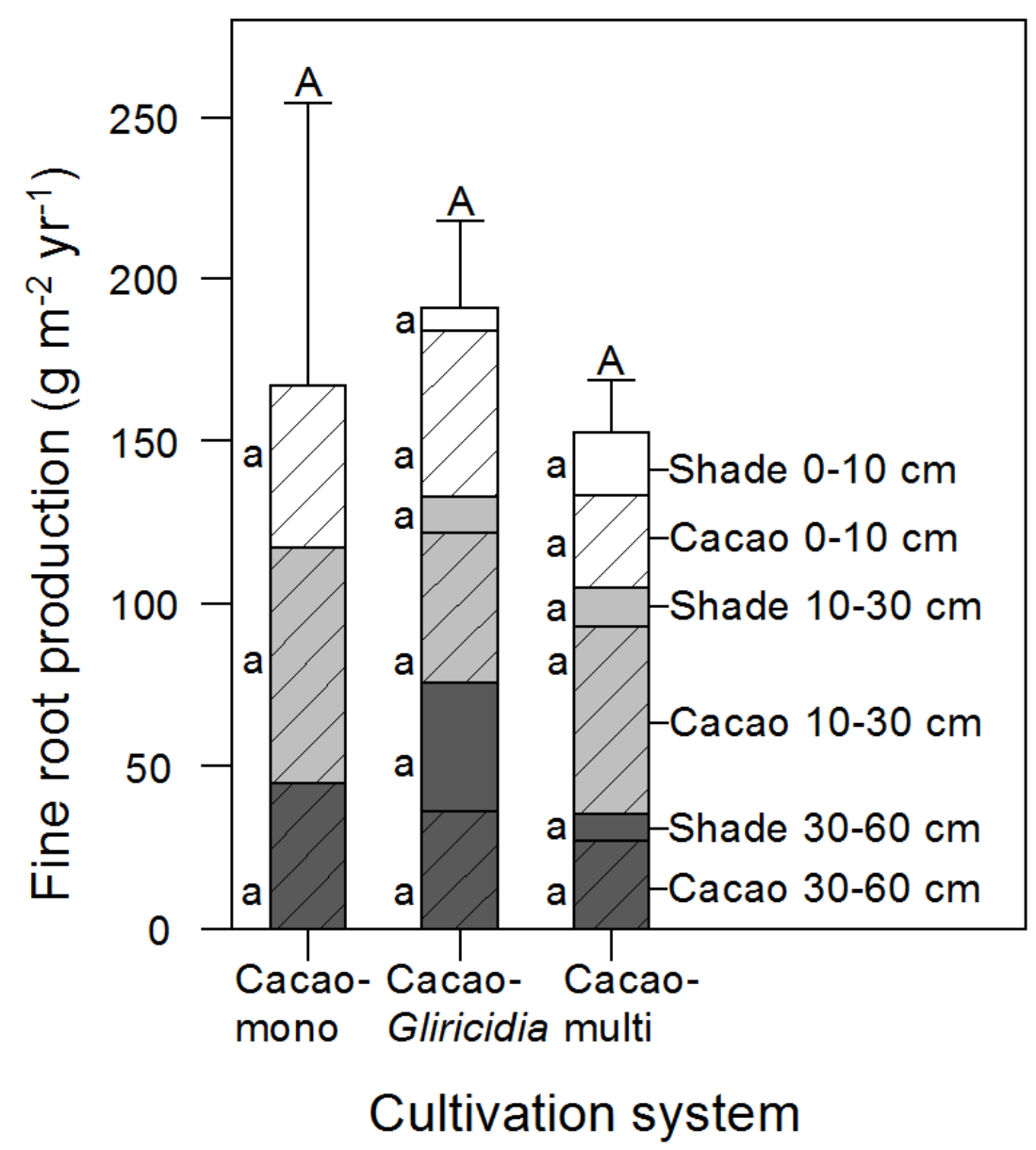

Figure 3.3: Fine root production in three different soil depths $(0-10 \mathrm{~cm}, 10-30 \mathrm{~cm}$ and $30-60 \mathrm{~cm})$ and the total profile from $0-60 \mathrm{~cm}$ soil depth of the different cacao agroforests in the Kulawi valley (Sulawesi, Indonesia) differentiated in cacao and shade trees. Capital letters indicate statistically significant differences between the agroforestry systems; lower case letters indicate statistically significant differences of the different tree groups between the cultivation systems and lower $(\mathrm{P}<$ $0.05)$. 
Fine root turnover rates in the entire $60 \mathrm{~cm}$ deep soil profiles for all tree species together did not differ significantly between cultivation systems with values ranging from 1.1 in cacao monocultures to 1.3 in Cacao-multi to 1.4 in Cacao-Gliricidia stands (Table 3.5). On species level, cacao trees in the Cacao-multi sites had a significantly higher fine root turnover in the total soil profile than in the Cacao-mono and the Cacao-Gliricidia plots. While fine root turnover of cacao trees was almost identical in the different soil depths in the Cacao-mono plots, cacao fine root turnover was markedly higher in the deeper soil depths of the Cacaomulti cultivation systems with shade trees (Table 3.5). Fine root turnover of the shade trees in the Cacao-Gliricidia systems was high particularly in the deeper soil depths and also significantly higher than that of cacao trees. In the Cacao-multi plots, this pattern was reverse with shade trees showing very low turnover rates that were significantly lower compared to the high fine root turnover rates of cacao trees in the different soil depths (Table 3.5).

Table 3.5: Fine root turnover in the soil profile of $0-60 \mathrm{~cm}$ depth of cacao and shade trees of the three cacao cultivation systems in the Kulawi valley (Sulawesi, Indonesia). Given are means and standard errors. Capital letters indicate statistically significant differences of all tree groups in the whole soil profile between the agroforestry systems; lower case Latin letters indicate statistically significant differences of the different tree groups between the cultivation systems and lower case Greek letters indicate statistically significant differences between cacao and shade trees within a cultivation system $(\mathrm{p}<0.05)$.

\begin{tabular}{|c|c|c|c|}
\hline Cultivation system & Tree group & depth (cm) & Fine root turnover \\
\hline Cacao-mono & Cacao & $\begin{array}{r}0-10 \\
10-30 \\
\text { total profile } 0-60\end{array}$ & $\begin{array}{l}1.2 \pm 0.3 \mathrm{a} \\
1.1 \pm 0.4 \mathrm{a} \\
1.1 \pm 0.2 \mathrm{aA}\end{array}$ \\
\hline \multirow[t]{3}{*}{ Cacao-Gliricidia } & Cacao & $\begin{array}{r}0-10 \\
10-30 \\
\text { total profile } \quad 0-60\end{array}$ & $\begin{array}{l}0.7 \pm 0.1 \mathrm{a} \alpha \\
1.7 \pm 0.6 \mathrm{a} \alpha \\
1.2 \pm 0.3 \mathrm{a} \alpha\end{array}$ \\
\hline & Gliricidia & $\begin{array}{r}0-10 \\
10-30 \\
\text { total profile } \quad 0-60\end{array}$ & $\begin{array}{l}1.7 \pm 0.3 \text { a } \beta \\
2.7 \pm 1.7 \text { a } \alpha \\
2.4 \pm 1.4 \text { a } \beta\end{array}$ \\
\hline & All trees & total profile $0-60$ & $1.4 \pm 0.3 \mathrm{~A}$ \\
\hline \multirow[t]{3}{*}{ Cacao-multi } & Cacao & $\begin{array}{r}0-10 \\
10-30 \\
\text { total profile } \quad 0-60\end{array}$ & $\begin{array}{l}2.0 \pm 1.0 \mathrm{a} \alpha \\
3.8 \pm 0.4 \mathrm{~b} \alpha \\
2.8 \pm 0.6 \mathrm{~b} \alpha\end{array}$ \\
\hline & Shade trees & $\begin{array}{r}0-10 \\
10-30 \\
\text { total profile } \quad 0-60\end{array}$ & $\begin{array}{l}0.5 \pm 0.1 \mathrm{~b} \beta \\
0.5 \pm 0.2 \mathrm{a} \beta \\
0.5 \pm 0.1 \mathrm{~b} \beta\end{array}$ \\
\hline & All trees & total profile $0-60$ & $1.3 \pm 0.2 \mathrm{~A}$ \\
\hline
\end{tabular}




\section{Fine root morphology}

Fine root morphological traits were also different between the three cacao cultivation systems and at different soil depths. Mean fine root diameter of cacao trees decreased from $0.6 \mathrm{~mm}$ in cacao monoculture to $0.5 \mathrm{~mm}$ in Cacao-Gliricidia to $0.4 \mathrm{~mm}$ in the Cacao-multi stands in the upper $20 \mathrm{~cm}$ (Table 3.6). Cacao fine root diameter was very similar in the soil profile below the uppermost $20 \mathrm{~cm}$ in Cacao-mono and Cacao-Gliricidia stands, but tended to be somewhat higher in these soil depths in the Cacao-multi stands. Shade trees had a markedly higher mean fine root diameter than cacao trees in both, the Cacao-Gliricidia and the Cacao-multi stands.

Specific root length and specific root area of cacao fine roots in the Cacao-mono and Cacao-Gliricidia stands was highest in $0-20 \mathrm{~cm}$ and $20-100 \mathrm{~cm}$ soil depth and tended to be lower in the lowermost 100-300 cm (Table 3.6). This pattern was similar in the Cacao-multi stands, were cacao fine roots had the highest specific root length and area numbers in $0-20 \mathrm{~cm}$ and 20-100 cm soil depth, while these two morphological fine root traits were lowest for cacao in 100-300 cm depth across all three cultivation systems (Table 3.6). Specific fine root length and area numbers of the shade trees were principally similar to that of cacao. Gliricidia shade trees in the Cacao-Gliricidia stands showed a decrease in specific root length and area with increasing soil depth. The same was true for the shade trees in the Cacao-multi systems, where fine roots of the shade trees showed the lowest numbers in 20-100 and 100-300 cm soil depth (Table 3.6). On single species level, shade trees in the Cacao-multi stands showed a large variety of mean fine root diameter, specific root length and area values (see Appendix Table A4). Mean fine root diameter ranged from 0.1 to $1.3 \mathrm{~mm}$, specific root length from 113 $\mathrm{m} \mathrm{g}^{-1}$ to $6347 \mathrm{~m} \mathrm{~g}^{-1}$, and specific root area from $30 \mathrm{~cm}^{2} \mathrm{~g}^{-1}$ to $459 \mathrm{~cm}^{2} \mathrm{~g}^{-1}$, respectively. 


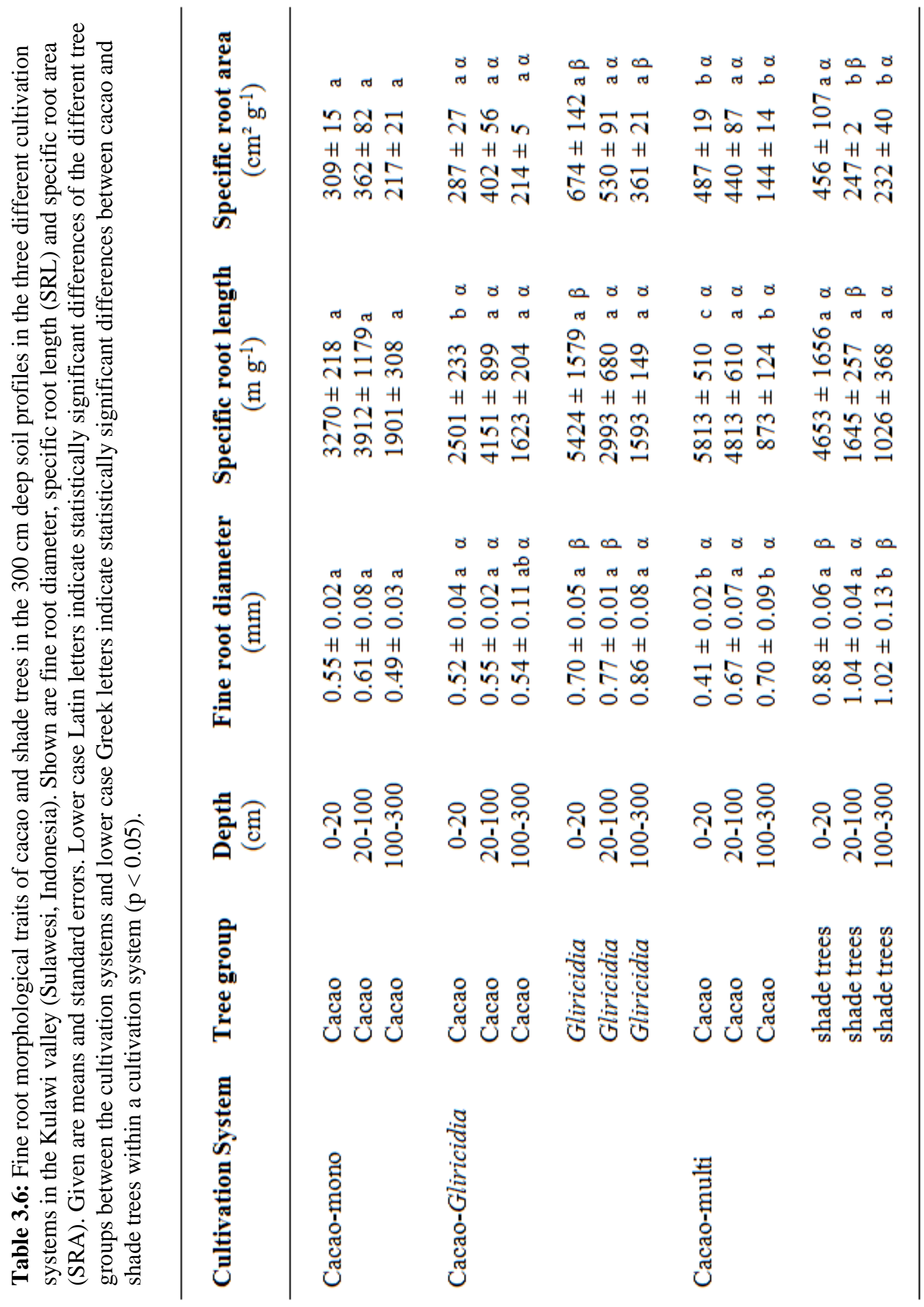




\section{Differences in depth of preferential soil water uptake}

The isotopic composition of soil water extracted during the soil desiccation period in 2011 ranged from -25.7 to $-75.9 \%\left(\delta^{2} \mathrm{H}\right)$ and -4.1 to $-11.5 \%$ o $\left(\delta^{18} \mathrm{O}\right)$. In a $\delta^{2} \mathrm{H}-\delta^{18} \mathrm{O}$ graph, xylem and soil water isotopic signatures plot close to the same regression line (data not shown). Evaporation during this period led to a clear differentiation of the isotopic composition in $\delta \mathrm{D}$ (and $\delta^{18} \mathrm{O}$, data not shown) of soil water at different soil depths in both cacao cultivation systems, with a decrease in the $\delta \mathrm{D}$ signature with increasing soil depth (Figure 3.4). The isotopic composition of plant water simultaneously extracted from stem wood tissue of cacao and shade trees suggest a complementary soil water use in case of the Cacao-Gliricidia cultivation system (Figure 3.4A), with cacao trees obtaining water mainly between 40 and 60 cm soil depth, while Gliricidia shade trees primarily taking up water from deeper soil depths. In case of the Cacao-multi treatment with the presence of various shade tree species a similar pattern of complementary soil water use of cacao and shade trees was not observed (Figure 3.4B). In contrast to the Cacao-Gliricidia system, both cacao and shade tree species primarily obtained water from soil depths from $60-100 \mathrm{~cm}$.

Cacao-Gliricidia

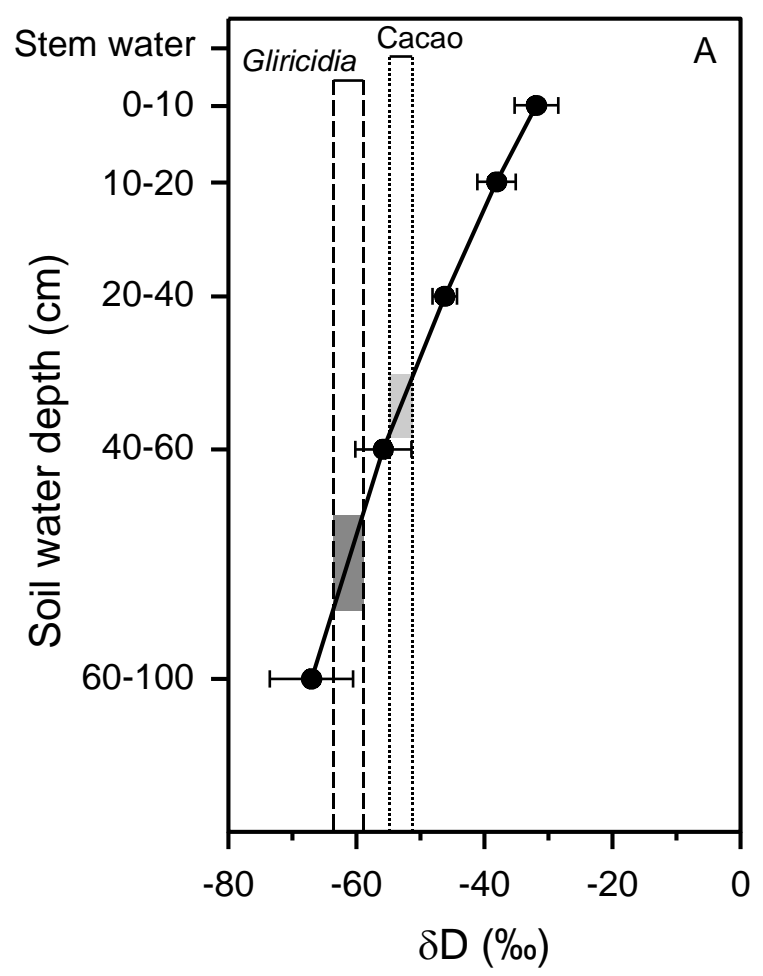

Cacao-multi

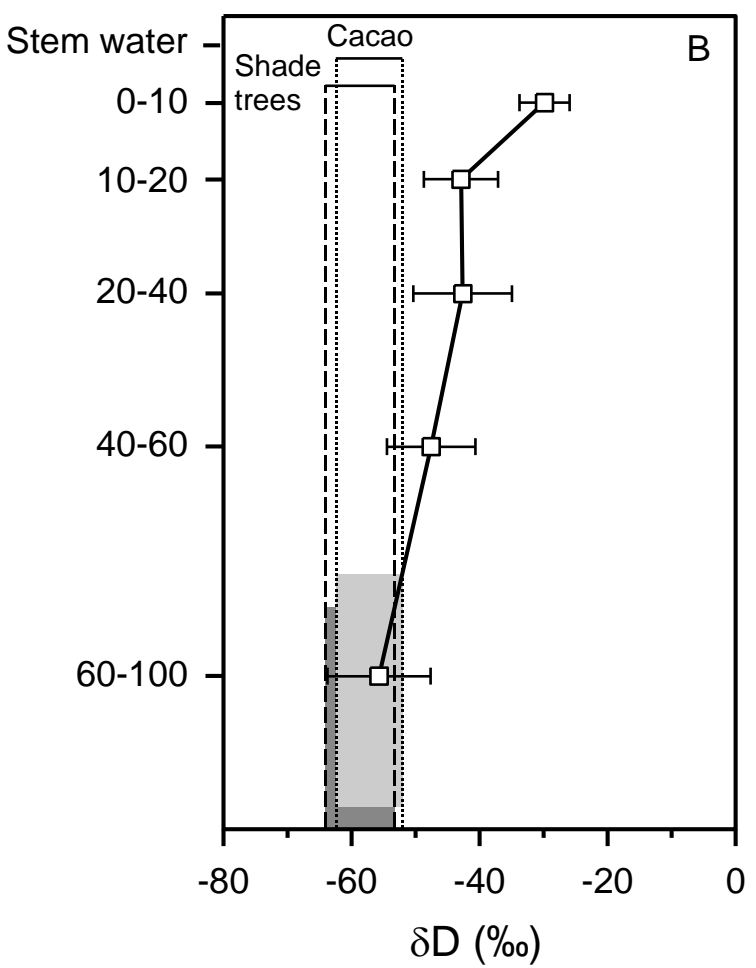

Figure 3.4: Isotopic composition in $\delta \mathrm{D}(\%)$ of soil water in different soil depths and in tree stem woody tissue of cacao, Gliricidia, and various other shade trees species in a Cacao-Gliricidia and a Cacao-multi plot in the Kulawi valley (Sulawesi, Indonesia). Given are means and standard deviation $(n=4)$. Dashed lines indicate the range of $\delta D$ values measured in the tree stems. Grey areas indicate the soil depths coinciding with the values found in the plant water in the stems. 
Interrelations between NPP, biomass, stand structure, and species diversity

A Principal Components Analysis (PCA) on the inter-relationships between above- and belowground net primary production and biomass, stand structural variables, and tree species diversity in the nine stands revealed a close association of the tested biomass and productivity variables with stand basal area, canopy cover, tree species diversity $\left(\mathrm{H}^{\prime}\right)$ and fine root bio- and necromass from 0-300 cm, but not with stem diameter, fine root biomass from 0-60 and fine root turnover and productivity from $0-60 \mathrm{~cm}$ (Table 3.7). Fine root biomass and production from 0-60 $\mathrm{cm}$ showed a close (negative) association with axis 2 (EV: -0.859). Tree density was associated to axis 1 (EV: -0.612) and 3 (EV: -0.618) and stem diameter and fine root turnover showed a close relation to axis 3 (EV: -0.630) and 4 (EV: -0.707) suggesting that fine root turnover is positively correlated to stem density. Variables concerning root biomass and productivity did not correlate with aboveground variables.

Table 3.7: Results of a Principal components analysis (PCA) based on the plots of the three studied cacao cultivation systems in the Kulawi valley (Sulawesi, Indonesia) and their corresponding data on above- and belowground net primary production, biomass, stand structural data and diversity. Given are the eigenvalues (EV) of the four main axes and the loading of sixteen parameters on these. The values in brackets give the cumulative fraction of variance explained by the variable. The most important factors on each axis are printed bold.

\begin{tabular}{|c|c|c|c|c|}
\hline Variables & $\begin{array}{c}\text { Axis 1 } \\
(\mathrm{EV} 0.5681)\end{array}$ & $\begin{array}{c}\text { Axis 2 } \\
(\mathrm{EV} 0.1465)\end{array}$ & $\begin{array}{c}\text { Axis 3 } \\
(\mathrm{EV} 0.1025)\end{array}$ & $\begin{array}{c}\text { Axis } 4 \\
(\text { EV 0.0755) }\end{array}$ \\
\hline Aboveground NPP & $-0.884(0.78)$ & $-0.096(0.79)$ & $0.149(0.81)$ & $0.163(0.84)$ \\
\hline Belowground NPP & $-0.809(0.65)$ & $-0.416(0.83)$ & $-0.351(0.95)$ & $-0.117(0.96)$ \\
\hline Total NPP & $-0.902(0.81)$ & $-0.161(0.84)$ & $0.082(0.85)$ & $0.125(0.86)$ \\
\hline Aboveground biomass & $-0.935(0.87)$ & $0.209(0.92)$ & $0.1854(0.95)$ & $-0.050(0.95)$ \\
\hline Belowground biomass & $-0.973(0.95)$ & $0.073(0.95)$ & $0.136(0.97)$ & $-0.022(0.97)$ \\
\hline Total biomass & $-0.945(0.89)$ & $0.179(0.93)$ & $0.175(0.96)$ & $-0.046(0.96)$ \\
\hline Tree density & $-0.612(0.37)$ & $0.416(0.55)$ & $-0.618(0.93)$ & $0.204(0.97)$ \\
\hline Stand basal area & $-0.892(0.80)$ & $0.325(0.90)$ & $0.049(0.90)$ & $-0.201(0.94)$ \\
\hline Stem diameter & $-0.454(0.21)$ & $0.086(0.21)$ & $0.637(0.62)$ & $-0.576(0.95)$ \\
\hline Canopy cover & $-0.641(0.41)$ & $0.378(0.55)$ & $-0.257(0.62)$ & $0.142(0.64)$ \\
\hline Shannon-Index & $-0.769(0.59)$ & $0.236(0.65)$ & $-0.226(0.70)$ & $0.261(0.77)$ \\
\hline Fine root biomass $(0-300 \mathrm{~cm})$ & $-0.859(0.74)$ & $-0.407(0.90)$ & $0.137(0.92)$ & $0.123(0.94)$ \\
\hline Fine root necromass $(0-300 \mathrm{~cm})$ & $-0.784(0.61)$ & $0.244(0.67)$ & $0.060(0.68)$ & $-0.060(0.68)$ \\
\hline Fine root biomass $(0-60 \mathrm{~cm})$ & $-0.377(0.14)$ & $-0.794(0.77)$ & $0.162(0.80)$ & $0.329(0.91)$ \\
\hline Fine root turnover $(0-60 \mathrm{~cm})$ & $-0.207(0.04)$ & $-0.193(0.08)$ & $-0.630(0.48)$ & $-0.707(0.98)$ \\
\hline Fine root production $(0-60 \mathrm{~cm})$ & $-0.459(0.21)$ & $-0.822(0.89)$ & $-0.227(0.94)$ & $-0.136(0.96)$ \\
\hline
\end{tabular}


Bivariate Pearson correlation analyses did not show a consistent pattern of interrelations for cacao and shade trees (Table 3.8). Fine root biomass of cacao trees seemed to be positively correlated to net primary production, fine root necromass, as well as fine root turnover and production. Beside the good interrelation between cacao fine root production and belowground NPP (resulting from allometric equation calculations), cacao fine root production was negatively correlated with fine root biomass $(0-300 \mathrm{~cm}$ depth), but positively with fine root necromass $(0-300 \mathrm{~cm})$ and fine root biomass $(0-60 \mathrm{~cm})$ (Table 3.8). In contrast to cacao trees, shade trees showed a positive correlation of fine root biomass to above- and belowground, and total tree biomass. Fine root production of shade trees showed only weak and mostly not significant correlations with tree biomass, NPP or stand structure variables. The only significant interrelationship was found in a negative (and weak) correlation with fine root turnover (Table 3.8). 


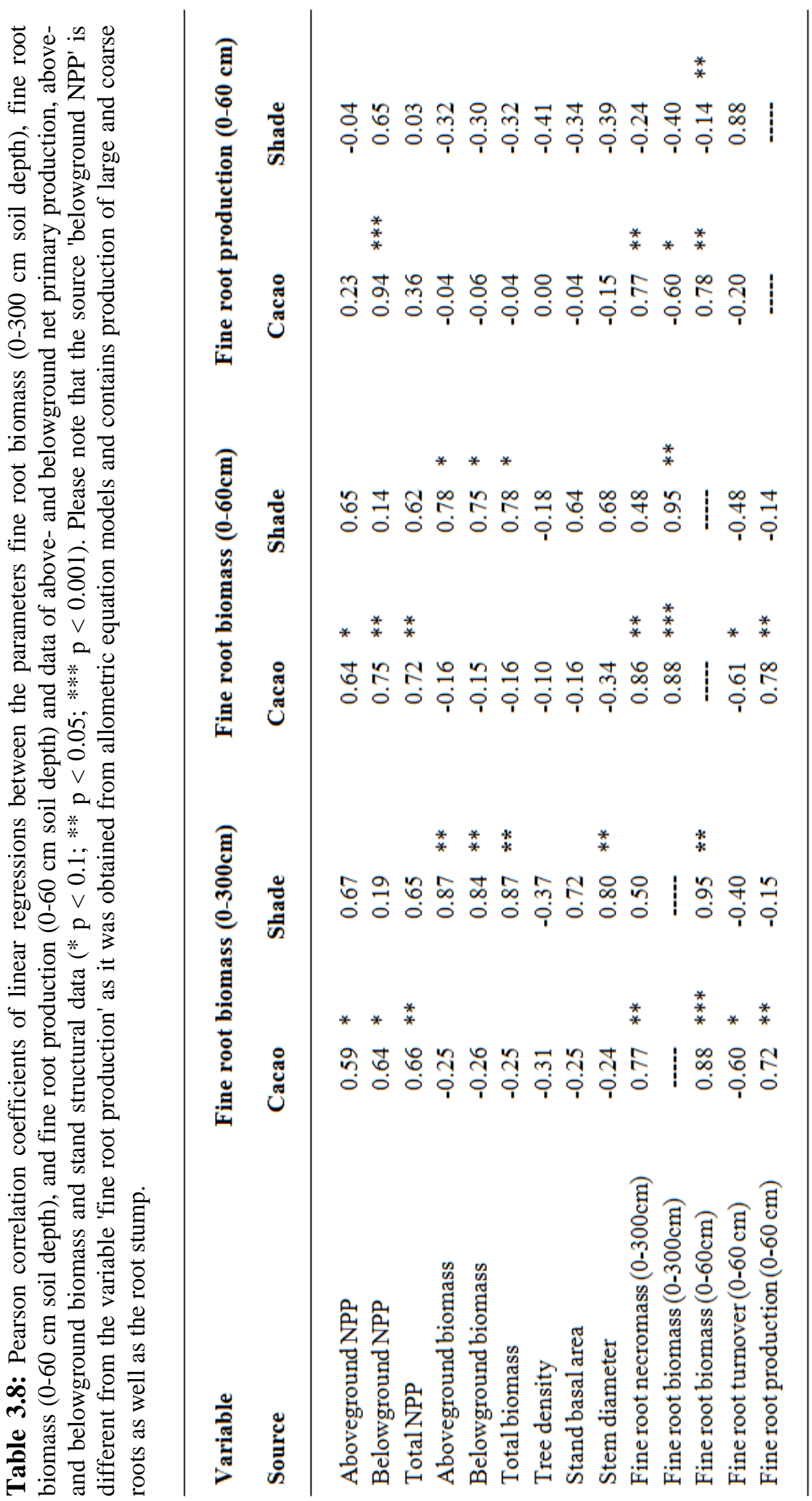




\subsection{Discussion}

\section{Standing root biomass of cacao and shade trees}

We tested the hypothesis that standing fine root biomass increases with increasing shade tree abundance and diversity of the cacao cultivation systems. Our study revealed that there is indeed an effect of species composition on biomass and rooting patterns, although singlespecies shade tree presence by G. sepium and a multi-shade tree layer did not show the same effect on cacao rooting patterns. Standing fine root biomass in the $300 \mathrm{~cm}$ deep profile was more than doubled along the diversity gradient from Cacao-mono to the Cacao-multi stands (206 to $432 \mathrm{~g} \mathrm{~m}^{-2}$ ), which must have increased the intensity of root competition, but due to high heterogeneity within the cultivation systems, the effect was not significant. Nevertheless, these results are consistent with a study from Harteveld et al. (2007) who found a decreasing trend of standing fine root biomass with increasing forest disturbance regime and thus with decreasing canopy cover. Our values are furthermore within the range of reported fine root biomass from different cacao cultivation systems (Kummerow et al. 1982, Muñoz and Beer 2001, Harteveld et al. 2007, Leuschner et al. 2009, Leuschner et al. 2013). Highest standing fine root biomass values in the Cacao-mono and the Cacao-Gliricidia stands were located in the upper $20 \mathrm{~cm}$ and decreased with increasing soil depth which is consistent to previous findings in forest ecosystems (e.g. Kummerow et al. 1982, Muñoz and Beer 2001, Harteveld et al. 2007, Meinen et al. 2009, Moser et al. 2010, Nygren et al. 2013, Hertel et al. 2013, Varik et al. 2013). A high concentration of fine roots in the upper soil layer is an important feature of the humid tropical ecosystem where they play a crucial role in storage and rapid recycling of nutrients (Khiewtam and Ramakrishnan 1993). The high concentration of fine roots in the surface layer may be attributed to high organic matter, $\mathrm{N}$ and available $\mathrm{P}$ contents in this layer (Upadhaya et al. 2005). In fact, most nutrients, especially $\mathrm{P}$ and $\mathrm{N}$, which mainly are available from decomposing organic material, are located in the topsoil and decrease downwards from the topsoil towards the subsoil (Upadhaya et al. 2005, Hertel et al. 2007, Hertel et al. 2009b, Varik et al. 2013). Furthermore, the superficial rooting pattern of cacao may be advantageous for the extraction of soil water resulting from throughfall and stemflow that may only reach the topsoil (Schwendenmann et al. 2010). However, in the Cacao-multi stands, highest standing fine root biomass was located in the subsoil in our study. Although the fact, that the subsoil is an important resource for nutrients and water uptake, not much is know about vertical root activity patterns (Lehmann 2003). Cacao fine root biomass was almost doubled compared to that of Gliricidia, whereas shade trees in the Cacao-multi system exceeded that of cacao almost 3-fold. The low cacao biomass values in the multi-species treatment could be explained by a very fast fine root turnover under the warm and moist conditions which does not allow for the accumulation of a large fine root biomass (Kummerow et al. 1982).

Likewise to fine root biomass, fine root necromass decreased with increasing soil depth, which is in accordance to other studies (e. g. Hertel et al. 2009a, Varik et al. 2013). We found highest 
fine root necromass numbers in the Cacao-multi sites, whereas the monocultures and the Cacao-Gliricidia plots differed only little. Harteveld et al. (2007) also found that necromass declined significantly from undisturbed forest towards cacao agroforestry systems. In accordance to the results of the present study, they did not observe an increase in fine root necromass while fine root biomass decreased which might be explained by rapid decomposition in the hot climate of Sulawesi and/or might result from a higher fine root biomass turnover at sites of higher land-use intensity (Hertel et al. 2009a). In our study, fine root necromass of cacao trees slightly decreased with increasing shade tree abundance and diversity. However, the ratio of living to dead fine root mass in the upper $60 \mathrm{~cm}$ of the soil was ca. 1.8 in the Cacao-mono plots, ca. 2.6 in the Cacao-Gliricidia plots, but only ca. 1.2 in the Cacao-multi plots suggesting that the intense root competition of cacao trees with the various shade tree species in the latter cultivation system must have result indeed in a shorter livespan and hence a higher production of fine root litter compared to the two other cultivation systems.

\section{Vertical root distribution of cacao and shade trees}

Our second hypothesis was that there is vertical root segregation between cacao and cooccurring shade trees for a more effective soil resources exploitation. Detailed studies of root biomass and root distribution patterns in Cacao-Gliricidia agroforests in nearby study area have shown that the root systems of cacao and Gliricidia were vertically stratified with cacao roots concentrating in the upper profile and Gliricidia roots in the subsoil (Moser et al. 2010). Indeed, stable isotope analyses confirmed that these two species showed complementary soil water use in these plantations (Schwendenmann et al. 2010). The results by Makumba et al. (2009) also confirmed vertical root segregation between Gliricidia and maize plants, where Gliricidia showed highest root length density in the subsoil from $40-100 \mathrm{~cm}$, and nutrient pumping from deep soil layers. Several other studies have confirmed the existence of root segregation in different soil depths (e.g. Schroth and Zech 1995, Akinnifesi et al. 2004). Another study from Lehmann (2003) revealed that shaded crops like coffee and cacao tend to have root activity in shallower soil depth than fruit trees and that most of cacao's root activity occurs in the topsoil.

Comparing fine root biomass values on the species level, it became apparent that indeed there was vertical root segregation between cacao and Gliricidia in the Cacao-Gliricidia systems, which is in accordance to the previously mentioned studies (Lehmann 2003, Makumba et al. 2009, Moser et al. 2010, Schwendenmann et al. 2010). Cacao displayed a shallower root system with clearly highest amounts of fine root biomass in the upper $20 \mathrm{~cm}$, whereas Gliricidia concentrated most of its fine root biomass in the subsoil layers below 100 $\mathrm{cm}$. The isotopic composition of plant water simultaneously extracted from stem wood tissue of cacao and shade trees further confirms a complementary soil water use in case of the CacaoGliricidia cultivation system, with cacao trees obtaining water mainly between 40 and $60 \mathrm{~cm}$ soil depth, while Gliricidia primarily took up water from deeper soil depths. This result confirms earlier investigations in similar cacao agroforests of the same region that also showed 
a clear vertical segregation of the water extracting root zone of cacao and Gliricidia shade trees (Moser et al. 2010, Schwendenmann et al. 2010). This complementarity may also have contributed to the enhanced water use in the Cacao-Gliricidia stand as described by Köhler et al. (2014), and probably as well to the slightly higher net primary production observed (Abou Rajab et al., in revision). The results from the Cacao-multi stand suggest that this result of a vertical root segregation of cacao and Gliricidia shade trees cannot be generalized. Other tree species and differently structured shade tree layers may show different characteristics. E.g. tree size has previously shown to affect the soil depth for preferential water uptake in tree species mixtures (Meinzer et al. 1999, Meißner et al. 2012), with smaller trees tapping at deeper sources of water than larger. Isaac et al. (2014) found a difference in the water acquisition zone of cacao growing in monoculture or in mixture. The active cacao roots in the soil water acquisition zone were located in 10-20 cm soil depth in cacao monoculture but in $10-30 \mathrm{~cm}$ for cacao in mixture, though these results were also influenced by the soil texture. In the Cacaomulti system of the present study, we have a clear indication that cacao and shade trees should use the same depth interval for soil water uptake. In contrast to the Cacao-Gliricidia stands, the presence of various shade trees in the Cacao-multi stands altered the standing fine rot biomass and vertical root distribution of cacao suggesting a displacement of cacao roots by the root competition of the co-occurring shade trees. Cacao fine roots were forced to grow into deeper soil layers than in the Cacao-mono and the Cacao-Gliricidia stands, although high amounts of shade tree fine roots were located in the subsoil below $100 \mathrm{~cm}$ soil depth as well. Schroth (1995) showed that concurrent growth with a competitive root system can reduce the growth of tree roots in the topsoil and promote tree root growth deeper in the profile. Lehmann (2003) shows in his data that especially crops like cacao grown under shade trees often show a more shallow fine root systems (see also Nygren et al. 2013). As the vertical fine root distribution of the cacao trees in our Cacao-multi sites was much different from that in the two other cultivation systems, we conclude that this must be a result of strong intraspecific root competition with the co-occurring shade tree species. This is also in accordance to Schenk (2006) who states that vertical root distribution often changes in response to root competition. We assume an asymmetric root competition between cacao and shade trees in the Cacao-multi sites, while there was only little competition among shade trees as shade tree roots were more abundant in the deeper soil depths. Asymmetric root competition is defined as an unequal division of resources amongst competing plants with some individuals or species removing a disproportionately large amount of a resource (Freckleton and Watkinson 2001). Formerly, root competition was suggested to be size-symmetric (e.g. Schwinning and Weiner 1998, Cahill and Casper 2000), but more and more studies show an asymmetric belowground competition (e. g. Rust and Savill 2000, Leuschner et al. 2001, Rajaniemi 2003, Raynaud and Leadley 2005). This asymmetric competition might evolve due to a difference in tree height or a variation in emergence time (Freckleton and Watkinson 2001), but also due to heterogeneity of resource availability (Rajaniemi 2003). Indeed, the height difference between cacao and shade trees was much higher in the Cacao-multi plots than in the Cacao-Gliricidia sites. Our 
data on fine root abundance, distribution and dynamics further support this assumption. Shade trees showed a very low fine root turnover, whereas turnover of cacao fine roots was more than doubled in the Cacao-multi plots compared to the other two cultivation types. Additionally to the altered vertical root distribution of cacao as mentioned before, the abundance of fine roots might provide further evidence for the competitive advantage of shade trees over cacao in the Cacao-multi plots. Fine root biomass of cacao was almost doubled in the Cacao-mono and Cacao-Gliricidia sites compared to the cacao fine root biomass in the Cacao-multi sites. Further confirmation is contributed by the results of differences in maximum rooting depths: mean maximum rooting depths of cacao fine, large and coarse roots reached deeper soil depths when growing together with various shade trees suggesting a higher competition between cacao and shade trees forcing the cacao to exploit more soil volume in deeper soil layers. The study of Isaac et al. (2014) revealed similar results showing strongly differentiated vertical coarse root distribution (roots $>2 \mathrm{~mm}$ ) between cacao in monoculture and in mixture with different shade trees. In their study, cacao in monoculture showed a shallower coarse root distribution than when growing with different shade trees.

Contrasting to previous studies from Moser at al. (2010) and Leuschner et al. (2013), we found coarse and large roots of cacao to occur also deeper than 160 and $40 \mathrm{~cm}$ in soil depth, respectively. Highest amounts of cacao large roots were present in the uppermost soil layer in all cultivation systems, whereas coarse roots of cacao trees showed a divergent rooting pattern. In the Cacao-multi stands, cacao coarse roots were present until $300 \mathrm{~cm}$ soil depth with a much deeper mean maximum rooting depths compared to the less diverse cultivation systems. Most cacao coarse roots concentrated in the subsoil compared to the Cacao-mono and the CacaoGliricidia stands, where they showed a more equal distribution throughout the soil profile. This again shows the effects different cultivation systems can have on cacao rooting patterns.

\section{Fine root morphological traits in cacao and shade tree species}

At least for temperate deciduous tree species it has been stated that trees could not only respond to the presence of one (or more) competing species by changes in fine root biomass and its vertical distribution in the soil, but trees could also modify their fine root morphological properties such as mean diameter, specific root area or length, or branching pattern (e.g. Meinen et al. 2009). Leuschner et al. (2004) and Ostonen et al. (2007) identified two main strategies of tree fine roots to adapt to different regimes of soil nutrient supply: trees could either enhance their carbon investment to increase the fine root biomass (and root length) or increase their nutrient uptake efficiency by changes in root morphology to form fine roots of higher specific root area. Similar strategies have also been suggested to explain differences in root competition ability of different tree species (Bauhus and Messier 1999). In the present study, mean fine root diameter of cacao trees decreased in the upper $20 \mathrm{~cm}$ of the soil with increasing shade tree abundance and diversity, whereas the average fine root diameter of shade trees was generally higher than that of cacao fine roots. The specific surface length and area of cacao fine roots was highest in $0-20 \mathrm{~cm}$ and in $20-100 \mathrm{~cm}$ soil depth, while it was lowest in the 
lower soil (100-300 cm) of the Cacao-multi stands. Therefore, it appears that elevated specific root area and length and associated thinner cacao fine roots in the Cacao-multi stands may indeed compensate for the decrease in fine root biomass observed in this system that might result from intense root competition with the various co-occurring shade trees. Furthermore, cacao trees had the lowest specific root length and area in $0-20 \mathrm{~cm}$ soil depth in the CacaoGliricidia stands, which might result from lower competition of cacao and Gliricidia due to their vertical root segregation. We conclude therefore that modification of fine root morphology might be indeed a mechanism in cacao trees to mediate intraspecific root competition effects with co-occurring shade trees on cacao fine root biomass.

\section{Fine root dynamics in cacao and shade trees}

We hypothesized that fine root production and turnover increases with increasing shade tree abundance and diversity. This was due to the theory built up in the past decades on the biodiversity-function relationship that assumes an increase in above- and belowground productivity with plant species diversity or diversity of plant functional types (e.g. Tilman et al. 1996, Hooper and Vitousek 1997, Hector 2001, Schmid et al. 2001, Dybzinski et al. 2008). One explanation of such 'overyielding' of species-rich stands is a more pronounced niche complementarity as compared to species-poor communities or even monocultures (Parrish and Bazzaz 1976, Hector et al. 1999, Hector 2001). Although this theory bases mainly on investigations in grasslands, studies from forest ecosystems have also brought evidence for this effect for both the above- and the belowground compartment of forests (e.g. Morgan et al. 1992, Bauhus et al. 2000, Erskine et al. 2006, Meinen et al. 2009). In contrast to our expectation, our results did not confirm that there is a significant influence of shade tree abundance and diversity on fine root productivity in the tropical cacao cultivation systems investigated. Total fine root production (cacao and shade trees if present) tended to be highest in the Cacao-Gliricidia and lowest in the Cacao-multi plantations. However, the differences were weak and statistically not different. The fine root production numbers estimated ranging from 153 to $191 \mathrm{~g} \mathrm{~m}^{-2} \mathrm{yr}^{-1}$ are relatively low compared to numbers from the literature e.g. from cacao agroforests under natural shade trees (Muñoz and Beer 2001, Harteveld et al. 2007, Leuschner et al. 2009). This might be due to the relative high age of around 20 years of the investigated plantations in case of our study. John et al. (2001) argued that fine root growth rate declines with age as more fine roots are converted into coarse roots to provide better structural support to older trees and therefore the annual fine root production declines, but it remains unclear if this is the main reason for the relatively low fine rot production numbers in our study. Harteveld et al. (2007) reported that approx. 60\% of the annual FRP took place in the upper $10 \mathrm{~cm}$ of the soil, which is in contrast to our results. Maybe this pattern is also a consequence of different rooting patterns and thus different competition conditions. In general, shade trees produced proportionally less fine roots than cacao trees and we could not find any effect of soil depth on fine root production neither in cacao nor in shade tree species. 
Differently, fine root turnover of cacao trees was markedly affected by the presence and diversity of shade trees. Fine root turnover decreased in the uppermost $10 \mathrm{~cm}$ of the soil, while it increased in the soil depth below $(10-30 \mathrm{~cm})$ in the Cacao-Gliricidia stands, where cacao and shade trees revealed a clear vertical root segregation in the soil compared to the Cacao-mono plots. In contrast, cacao fine root turnover rates were highest in the Cacao-multi systems in all soil depths investigated. Again, this result points to a decrease in fine root lifespan due to a severe asymmetric root competition by the co-occurring various shade tree species that was already visible by the marked change in standing cacao fine root biomass and the vertical rooting pattern in the Cacao-multi cultivation system. However, this competitive reduction in fine root biomass seems at least partly to be compensated by the cacao trees by a change in fine root morphological properties: in the Cacao-multi stands, a relatively large proportion of the cacao fine roots in smaller size classes, which have a large surface area and length in relation to their volume thus are more efficient for nutrient and water uptake are prevalent.

\subsection{Conclusions}

In agroforestry systems, the understanding of the response of the root systems and their spatial distribution is crucial to long-term sustainability of both yields and ecosystem services. Earlier results have shown, that the presence of a diverse shade tree cover in cacao cultivation systems does not necessarily lead to reduced cacao bean yield (Abou Rajab et al., in revision). The results from our recent study show that the presence of shade trees can lead as well as it doesn't necessarily imply a vertical root segregation with marked consequences for the root competition effects between crop (cacao) and shade trees. However, although multi-species shade tree abundance does obviously not affect fine root productivity, the vertical root distribution of cacao roots is altered by the presence of a multi-species shade tree abundance as well as the fine root turnover (through lowered fine root lifespan) is enhanced. Notably, cacao trees respond to the competition effect of the reduction in cacao fine roots by co-occurring shade tree species with a modification of their root morphological traits to compensate the decrease in fine root biomass by a more efficient soil resource uptake capacity.

\section{Acknowledgements}

This study was financed by the German Research Foundation (DFG) in the framework of the interdisciplinary German-Indonesian research project ELUC ('Environmental and land-use change in Sulawesi, Indonesia') and the collaborative research center CRC990 'Ecological and Socioeconomic Functions of Tropical Lowland Rainforest Transformation Systems (Sumatra, Indonesia)'. Special thanks go to Andrea Hanf for providing data of Deuterium stable isotope analysis. We are very thankful to our local assistants in the Kulawi valley and in Palu for supporting our study and we particularly thank RISTEK, the village heads and local plot owners for making this study possible. 


\section{Appendix}

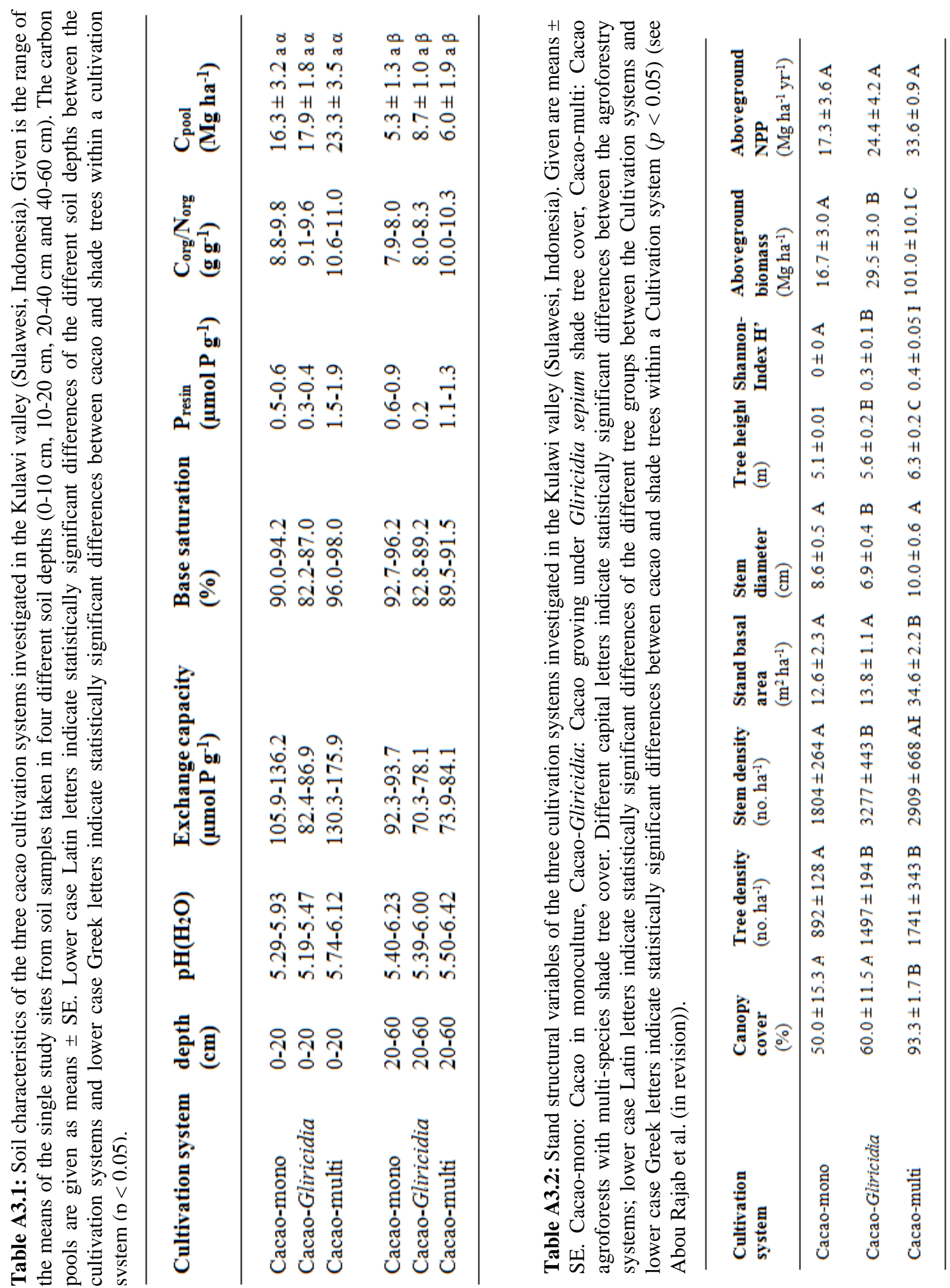


Table A3.3: Necromass of fine roots $(\mathrm{d}<2 \mathrm{~mm})$ of cacao trees and shade trees in the different soil depths of the three cacao agroforestry systems in the Kulawi valley (Sulawesi, Indonesia). The percentage proportion of the profile's total in a given soil depth is given in brackets. Different capital letters indicate statistically significant differences between the agroforestry systems; lower case Latin letters indicate statistically significant differences of the different soil depths between the cultivation systems and lower case Greek letters indicate statistically significant differences between cacao and shade trees within a cultivation system $(\mathrm{p}<0.05)$.

\begin{tabular}{|c|c|c|c|c|}
\hline \multirow{2}{*}{$\begin{array}{l}\text { Cultivation system } \\
\text { Cacao-mono }\end{array}$} & \multirow{2}{*}{$\begin{array}{l}\text { Tree group } \\
\text { Cacao }\end{array}$} & \multirow{2}{*}{$\begin{array}{l}\text { Depth }(\mathrm{cm}) \\
0-20\end{array}$} & \multicolumn{2}{|c|}{$\begin{array}{l}\text { Fine root necromass }\left(\mathrm{g} \mathrm{m}^{-2}\right)(\mathrm{d} \\
\qquad 2 \mathrm{~mm})\end{array}$} \\
\hline & & & $44.5 \pm 4.9(68.7)$ & $\mathrm{a}$ \\
\hline & & $20-60$ & $20.3 \pm 7.7(31.3)$ & $\mathrm{a}$ \\
\hline & & profile & $64.8 \pm 12.6$ & A \\
\hline \multirow[t]{6}{*}{ Cacao-Gliricidia } & Cacao & $0-20$ & $35.6 \pm 7.0(68.6)$ & \\
\hline & & $20-60$ & $16.3 \pm 2.8(31.4)$ & \\
\hline & & profile & $51.9 \pm 9.1$ & $\mathrm{~A} \alpha$ \\
\hline & Gliricidia & $0-20$ & $2.6 \pm 0.2(26.2)$ & a $\beta$ \\
\hline & & $20-60$ & $7.3 \pm 4.1(73.8)$ & a $\alpha$ \\
\hline & & profile & $10.0 \pm 4.1$ & $A \beta$ \\
\hline \multirow[t]{6}{*}{ Cacao-multi } & Cacao & $0-20$ & $28.4 \pm 6.4(67.3)$ & a $\alpha$ \\
\hline & & $20-60$ & $13.8 \pm 6.4(32.7)$ & a $\alpha$ \\
\hline & & profile & $42.1 \pm 10.3$ & $\mathrm{~A} \alpha$ \\
\hline & shade & $0-20$ & $56.0 \pm 15.0$ & $b \beta$ \\
\hline & & $20-60$ & $39.3 \pm 10.1$ & \\
\hline & & profile & $95.4 \pm 20.8$ & B $\beta$ \\
\hline
\end{tabular}


Table A3.4: Fine root morphology on a species level of shade tree species in the Cacao-multi cultivation systems in the Kulawi valley (Sulawesi, Indonesia). Shown are mean fine root diameter, specific root length (SRL) and specific root area (SRA). Given are means and standard errors.

Tree species

Aleurites moluccana
Callicarpa sp.
Carica papaya
Ceiba pentandra
Citrus sp.
Cocos nucifera
Durio zibethinus
Gliricidia sepium
Lansium domesticum
Geucaena leucocephala

Musa sp.

Persea americana

Pterocarpus indicus

Syzygium cf. Malaccense

\section{Plant family Soil depth Diameter \\ $(\mathrm{cm})$}

$(\mathrm{mm})$
Euphorbiaceae

Lamiaceae

\section{Caricaceae}

Malvaceae

Rutaceae

Arecaceae

Malvaceae

Fabaceae

Gnetaceae

Meliaceae

Fabaceae

Musaceae

Lauraceae

Fabaceae

Myrtaceae

0-20

20-100

0-20

20-100

100-300

0-20

0-20

20-100

$0.3 \pm 0.3$

100-300

$0.1 \pm 0.1$

0-20

$1.3 \pm 0.1$

20-100

$1.3 \pm 0$

100-300

$1.3 \pm 0$

0-20

$0.2 \pm 0.2$

20-100

0-20

$0.1 \pm 0.1$

20-100

$0.1 \pm 0.1$

20-100

0-20

$0.1 \pm 0.1$

20-100

100-300

0-20

$0.1 \pm 0.1$

20-100

$0.3 \pm 0.3$

0-20

$0.1 \pm 0.1$

20-100

$0.1 \pm 0.1$

0-20

$0.3 \pm 0.3$

20-100

$0.3 \pm 0.3$

100-300

$0.3 \pm 0.3$

0-20

$0.1 \pm 0.1$

$\begin{array}{cccc}0-20 & 0.5 \pm 0.5 & 145.8 \pm 145.8 & 43.3 \pm 43.3 \\ 20-100 & 0.3 \pm 0.3 & 297.0 \pm 297.0 & 80.8 \pm 80.8 \\ 100-300 & 0.3 \pm 0.3 & 245.2 \pm 245.2 & 69.5 \pm 69.5\end{array}$

$0.2 \pm 0.2$

$749.0 \pm 749.0$

$115.1 \pm 115.1$

$0.3 \pm 0.3$

$417.5 \pm 417.5$

$74.9 \pm 74.9$

$100-300 \quad 0.4 \pm 0.4$

$113.2 \pm 113.2$

$44.3 \pm 44.3$

$20-100 \quad 0.5 \pm 0.5$

$128.1 \pm 128.1$

$56.8 \pm 56.8$

$0.3 \pm 0.3$

$237.7 \pm 237.7$

$52.9 \pm 52.9$

$0.4 \pm 0.4$

$151.1 \pm 151.1$

$47.6 \pm 47.6$

$0.4 \pm 0.4$

$205.5 \pm 205.5$

$76.8 \pm 76.8$

$0.2 \pm 0.2$

$1172.1 \pm 1172.1$

$189.6 \pm 189.6$

$0.4 \pm 0.4$

$115.3 \pm 115.3$

$39.4 \pm 39.4$

$204.6 \pm 204.6$

$49.6 \pm 49.6$

$1190.3 \pm 1190.3$

$114.3 \pm 114.3$

$361.9 \pm 72.0$

$125.8 \pm 17.4$

$543.6 \pm 135.9$

$152.2 \pm 20.9$

$434.2 \pm 85.5$

$171.9 \pm 34.1$

$0.4 \pm 0.4$

$1445.6 \pm 1445.6$

$189.0 \pm 189.0$

100-300

$0.3 \pm 0.3$

$309.3 \pm 309.3$

$104.8 \pm 104.8$

$603.1 \pm 603.1$

$116.9 \pm 116.9$

$5037.8 \pm 5037.8$

$429.9 \pm 429.9$

$0.2 \pm 0.2$

$3677.6 \pm 3677.6$

$307.4 \pm 307.4$

$698.1 \pm 698.1$

$115.9 \pm 115.9$

$0.2 \pm 0.2$

$749.1 \pm 749.1$

$91.1 \pm 91.1$

$0.2 \pm 0.2$

$511.8 \pm 511.8$

$74.7 \pm 74.7$

$791.1 \pm 791.1$

$103.3 \pm 103.3$

$3066.7 \pm 3066.7$

$364.0 \pm 364.0$

$480.6 \pm 480.6$

$121.2 \pm 121.2$

$1448.0 \pm 1448.0$

$171.4 \pm 171.4$

$1270.2 \pm 1270.2$

$170.4 \pm 170.4$

$113.4 \pm 113.4$

$30.3 \pm 30.3$

$149.0 \pm 149.0$

$44.5 \pm 44.5$

$196.3 \pm 196.3$

$55.1 \pm 55.1$

20-100
$6384.1 \pm 6384.1$

$4329.3 \pm 4329.3$ 


\section{References}

Aber, J., J. Melillo, and K. Nadelhoffer. 1985. Fine root turnover in forest ecosystems in relation to quantity and form of nitrogen availability: a comparison of two methods. Oecologia 66:317-321.

Achard, F., H. D. Eva, H.-J. Stibig, P. Mayaux, J. Gallego, T. Richards, and J.-P. Malingreau. 2002. Determination of deforestation rates of the world's humid tropical forests. Science 297:999-1002.

Aerts, R., C. Bakker, and H. De Caluwe. 1992. Root turnover as determinant of the cycling of $\mathrm{C}, \mathrm{N}$, and $\mathrm{P}$ in a dry heathland ecosystem. Biogeochemistry 15:175-190.

Akinnifesi, F. K., B. T. Kang, and D. O. Ladipo. 1999. Structural root form and fine root distribution of some woody species evaluated for agroforestry systems. Agroforestry Systems 42:121-138.

Akinnifesi, F. K., E. C. Rowe, S. J. Livesley, F. Kwesiga, B. Vanlauwe, and J. Alegre. 2004. Tree Root Architecture. Pages 61-81 Belowground Interactions in Tropical Agroecosystems: Concepts and Models with Multiple Plant Components.

Bauhus, J., P. K. Khanna, and N. Menden. 2000. Aboveground and belowground interactions in mixed plantations of Eucalyptus globulus and Acacia mearnsii. Canadian Journal of Forest Research 30:1886-1894.

Bauhus, J., and C. Messier. 1999. Soil exploitation strategies of fine roots in different tree species of the southern boreal forest of eastern Canada. Canadian Journal of Forest Research 29:260-273.

Bisseleua, D., A. Missoup, and S. Vidal. 2009. Biodiversity conservation, ecosystem functioning, and economic incentives under cocoa agroforestry intensification. Conservation Biology 23:1176-1184.

Cahill Jr, J. F., and B. B. Casper. 2000. Investigating the relationship between neighbor root biomass and belowground competition: field evidence for symmetric competition belowground. Oikos 90: 311-320.

Canadell, J., R. Jackson, and J. Ehleringer. 1996. Maximum rooting depth of vegetation types at the global scale. Oecologia 108:583-595.

Dybzinski, R., J. E. Fargione, D. R. Zak, D. Fornara, and D. Tilman. 2008. Soil fertility increases with plant species diversity in a long-term biodiversity experiment. Oecologia 158:85-93. 
Ehleringer, J. R. and C. B. Osmond. 1989. Stable Isotopes. Pages 319-364 in Pearcy, R.W., Ehleringer, J. R., Mooney, H. A., Rundel, P. W., editors. Plant physiological ecology: field methods and instrumentation. Chapman and Hall, New York.

Erskine, P. D., D. Lamb, and M. Bristow. 2006. Tree species diversity and ecosystem function: Can tropical multi-species plantations generate greater productivity? Forest Ecology and Management 233:205-210.

Ewel, J., and M. Mazzarino. 2008. Competition from below for light and nutrients shifts productivity among tropical species. Proceedings of the National Academy of Sciences of the United States of America 105:18836-18841.

Freckleton, R. P., and A. R. Watkinson. 2001. Asymmetric competition between plant species. Functional Ecology 15: 615-623.

Gale M. R. and Grigal D. F. 1987. Vertical root distributions of northern tree species in relation to successional status. Canadian Journal of Forest Research 17:829-834.

Gaul, D., D. Hertel, W. Borken, E. Matzner, and C. Leuschner. 2008. Effects of experimental drought on the fine root system of mature Norway spruce. Forest Ecology and Management 256:1151-1159.

Guo, L. B., M. J. Halliday, S. J. M. Siakimotu, and R. M. Gifford. 2005. Fine root production and litter input: Its effects on soil carbon. Plant and Soil 272:1-10.

Hansen, M. C., P. V. Potapov, R. Moore, M. Hancher, S. A. Turubanova, A. Tyukavina, D. Thau, S. V. Stehman, S. J. Goetz, T. R. Loveland, A. Kommareddy, A. Egorov, L. Chini, C. O. Justice, and J. R. G. Townshend. 2013. High-resolution global maps of 21stcentury forest cover change. Science 342:850-3.

Harteveld, M., D. Hertel, M. Wiens, and C. Leuschner. 2007. Spatial and temporal variability of fine root abundance and growth in tropical moist forests and agroforestry systems (Sulawesi, Indonesia). Ecotropica 13:111-120.

Hector, A. 1999. Plant Diversity and Productivity Experiments in European Grasslands. Science 286:1123-1127.

Hector, A. 2001. Biodiversity and functioning of grassland ecosystems: multi-site comparison. Pages 71-95 in A. P. Kinzig, S. W. Pacala, and D. Tilman, editors. The functional consequences of biodiversity: empirical progress and theoretical extensions. Princeton University Press, Princton. 
Hertel, D., and C. Leuschner. 2002. A comparison of four different fine root production estimates with ecosystem carbon balance data in a Fagus-Quercus mixed forest. Plant and Soil 239:237-251.

Hertel, D., C. Leuschner, M. Harteveld, and M. Wiens. 2007. Fine root mass, distribution and regeneration in disturbed primary forests and secondary forests of the moist tropics. Stability of Tropical Rainforest Margins: Linking Ecological, Economic and Social Constraints of Land Use and Conservation:89-108.

Hertel, D., M. Harteveld, and C. Leuschner. 2009a. Conversion of a tropical forest into agroforest alters the fine root-related carbon flux to the soil. Soil Biology and Biochemistry 41:481-490.

Hertel, D., G. Moser, H. Culmsee, S. Erasmi, V. Horna, B. Schuldt, and C. Leuschner. 2009b. Below- and above-ground biomass and net primary production in a paleotropical natural forest (Sulawesi, Indonesia) as compared to neotropical forests. Forest Ecology and Management 258:1904-1912.

Hertel, D., T. Strecker, H. Müller-Haubold, and C. Leuschner. 2013. Fine root biomass and dynamics in beech forests across a precipitation gradient - Is optimal resource partitioning theory applicable to water-limited mature trees? Journal of Ecology 101:1183-1200.

Hooper, D. U., and P. M. Vitousek. 1997. The effects of plant composition and diversity on ecosystem processes. Science 277:1302-1305.

Isaac, M. E., Anglaaere, L. C., Borden, K., and S. Adu-Bredu. 2014. Intraspecific root plasticity in agroforestry systems across edaphic conditions. Agriculture, Ecosystems \& Environment 185: 16-23.

John, B., H. N. Pandey, and R. S. Tripathi. 2001. Vertical distribution and seasonal changes of fine and coarse root mass in Pinus kesiya royle ex.Gordon forest of three different ages. Acta Oecologica 22:293-300.

Jordan, C. F., and G. Escalante. 1980. Root Productivity in an Amazonian Rain Forest. Ecology 61:14-18.

Khiewtam, R. S., and P. S. Ramakrishnan. 1993. Litter and fine root dynamics of a relict sacred grove forest at Cherrapunji in north-eastern India. Forest Ecology and Management 60:327-344.

Köhler, M., A. Hanf, H. Barus, Hendrayanto, and D. Hölscher. 2014. Cacao trees under different shade tree shelter: effects on water use. Agroforestry systems 88:63-73. 
Kummerow, J., M. Kummerow, and W. da Silva. 1982. Fine-root growth dynamics in cacao (Theobroma cacao). Plant and Soil 65:193-201.

Lehmann, J. 2003. Subsoil root activity in tree-based cropping systems. Plant and Soil 255:319-331.

Leuschner, C., M. Harteveld, and D. Hertel. 2009. Consequences of increasing forest use intensity for biomass, morphology and growth of fine roots in a tropical moist forest on Sulawesi, Indonesia. Agriculture, Ecosystems \& Environment 129:474-481.

Leuschner, C., D. Hertel, H. Coners, and V. Büttner. 2001. Root competition between beech and oak: a hypothesis. Oecologia 126:276-284.

Leuschner, C., G. Moser, D. Hertel, S. Erasmi, D. Leitner, H. Culmsee, B. Schuldt, and L. Schwendenmann. 2013. Conversion of tropical moist forest into cacao agroforest: consequences for carbon pools and annual C sequestration. Agroforestry Systems $87: 1173-1187$.

Leuschner, C., M. Wiens, and M. Harteveld. 2006. Patterns of fine root mass and distribution along a disturbance gradient in a tropical montane forest, Central Sulawesi (Indonesia). Plant and soil 283:163-174.

Lewis, S. L., D. P. Edwards, D. Galbraith. 2015. Increasing human dominance of tropical forests. Science 359:827-32.

Livesley, S. J., P. J. Gregory, and R. J. Buresh. 2000. Competition in tree row agroforestry systems. 1. Distribution and dynamics of fine root length and biomass. Plant and Soil 227:149-161.

Makumba, W., F. K. Akinnifesi, and B. H. Janssen. 2009. Spatial rooting patterns of Gliricidia, pigeon pea and maize intercrops and effect on profile soil $\mathrm{N}$ and $\mathrm{P}$ distribution in southern Malawi. African Journal of Agricultural Research 4:278-288.

Margono, B. A., P. V. Potapov, S. Turubanova, F. Stolle, and M. Hansen. 2014. Primary forest cover loss in Indonesia over 2000-2012. Nature Climate Change 4:1-6.

Margono, B. A., S. Turubanova, I. Zhuravleva, P. Potapov, A. Tyukavina, A. Baccini, S. Goetz, and M. C. Hansen. 2012. Mapping and monitoring deforestation and forest degradation in Sumatra (Indonesia) using Landsat time series data sets from 1990 to 2010. Environmental Research Letters 7:034010. 
Meinen, C., D. Hertel, and C. Leuschner. 2009. Biomass and morphology of fine roots in temperate broad-leaved forests differing in tree species diversity: is there evidence of below-ground overyielding? Oecologia 161:99-111.

Meinzer, F. C., J. L. Andrade, G. Goldstein, N. M. Holbrook, J. Cavelier, and S. J. Wright. 1999. Partitioning of soil water among canopy trees in a seasonally dry tropical forest. Oecologia 121:293-301.

Meißner, M., M. Köhler, L. Schwendenmann, and D. Hölscher. 2012. Partitioning of soil water among canopy trees during a soil desiccation period in a temperate mixed forest. Biogeosciences 9:3465-3474.

Miettinen, J., C. Shi, and S. C. Liew. 2011. Deforestation rates in insular Southeast Asia between 2000 and 2010. Global Change Biology 17:2261-2270.

Morgan, J. L., J. M. Campbell, and D. C. Malcolm. 1992. Nitrogen relations of mixed-species stands on oligotrophic soils. Pages 65-85 in M. G. R. Cannell, D. C. Malcolm, and P. A. Robertson, editors. The ecology of mixed-species stands of trees. Blackwell, London.

Moser, G., C. Leuschner, D. Hertel, D. Hölscher, M. Köhler, D. Leitner, B. Michalzik, E. Prihastanti, S. Tjitrosemito, and L. Schwendenmann. 2010. Response of cocoa trees (Theobroma cacao) to a 13-month desiccation period in Sulawesi, Indonesia. Agroforestry Systems 79:171-187.

Muñoz, F., and J. Beer. 2001. Fine root dynamics of shaded cacao plantations in Costa Rica. Agroforestry Systems 51:119-130.

Nepstad, D., C. de Carvalho, and E. Davidson. 1994. The role of deep roots in the hydrological and carbon cycles of Amazonian forests and pastures. Nature 372:666-669.

Nygren, P., and H. Leblanc. 2009. Natural abundance of $15 \mathrm{~N}$ in two cacao plantations with legume and non-legume shade trees. Agroforestry systems 76:303-315.

Nygren, P., H. Leblanc, M. Lu, and C. Luciano. 2013. Distribution of coarse and fine roots of Theobroma cacao and shade tree Inga edulis in a cocoa plantation. Annals of forest science 70:229-239.

Ong, C. K., R. M. Kho, and S. Radersma. 2004. Ecological interactions in multispecies agroecosystems: concepts and rules. CABI Publishing, Wallingford.

Ostonen, I., K. Lõhmus, H.-S. Helmisaari, J. Truu, and S. Meel. 2007. Fine root morphological adaptations in Scots pine, Norway spruce and silver birch along a latitudinal gradient in boreal forests. Tree physiology 27:1627-1634. 
Parrish, J. A. D., and F. A. Bazzaz. 1976. Underground Niche Separation in Successional Plants. Ecology 57:1281-1288.

Persson, H. 1980. Fine-root dynamics in a Scots pine stand with and without near-optimum nutrient and water regimes. Acta Phytogeographica Suecica 68:101-110.

van Praag, H. J., S. Sougnez-Remy, F. Weissen, and G. Carletti. 1988. Root turnover in a beech and a spruce stand of the Belgian Ardennes. Plant and Soil 105:87-103.

Rajaniemi, T. K. 2003. Evidence for size asymmetry of belowground competition. Basic and Applied Ecology 4: 239-247.

Raynaud, X., and P. W. Leadley. 2005. Symmetry of belowground competition in a spatially explicit model of nutrient competition. Ecological Modelling 189: 447-453.

Rice, R. A., and R. Greenberg. 2000. Cacao Cultivation and the Conservation of Biological Diversity. Ambio: A Journal of the Human Environment 29:167-173.

Rust, S., and P. S. Savill. 2000. The root systems of Fraxinus excelsior and Fagus sylvatica and their competitive relationships. Forestry 73: 499-508.

Schenk, H. J. 2006. Root competition: beyond resource depletion. Journal of Ecology 94: 725-739.

Schmid, B., J. Joshi, and F. Schläpfer. 2001. Empirical evidence for biodiversity-ecosystem functioning relationships. Pages 120-150 in A. Kinzig, S. Pacala, and D. Tilman, editors. The functional consequences of biodiversity: Experimental progress and theoretical extensions. Princeton University Press, Princton.

Schroth, G. 1995. Tree root characteristics as criteria for species selection and systems design in agroforestry. Agroforestry Systems 30:125-143.

Schroth, G. 1999. A review of belowground interactions in agroforestry, focussing on mechanisms and management options. Agroforestry Systems 43:5-34.

Schroth, G., D. Kolbe, B. Pity, and W. Zech. 1996. Root system characteristics with agroforestry relevance of nine leguminous tree species and a spontaneous fallow in a semi-deciduous rainforest area of West Africa. Forest Ecology and Management 84:199_ 208.

Schroth, G., and W. Zech. 1995. Above- and below-ground biomass dynamics in a sole cropping and an alley cropping system withGliricidia sepium in the semi-deciduous rainforest zone of West Africa. Agroforestry Systems 31:181-198. 
Schwendenmann, L., E. Veldkamp, G. Moser, D. Hölscher, M. Köhler, Y. Clough, I. Anas, G. Djajakirana, S. Erasmi, D. Hertel, D. Leitner, C. Leuschner, B. Michalzik, P. Propastin, A. Tjoa, T. Tscharntke, and O. van Straaten. 2010. Effects of an experimental drought on the functioning of a cacao agroforestry system, Sulawesi, Indonesia. Global Change Biology 16:1515-1530.

Schwinning, S., and J. Weiner. 1998. Mechanisms determining the degree of size asymmetry in competition among plants. Oecologia, 113: 447-455.

Steffan-Dewenter, I., M. Kessler, J. Barkmann, M. M. Bos, D. Buchori, S. Erasmi, H. Faust, G. Gerold, K. Glenk, S. R. Gradstein, E. Guhardja, M. Harteveld, D. Hertel, P. Höhn, M. Kappas, S. Köhler, C. Leuschner, M. Maertens, R. Marggraf, S. Migge-Kleian, J. Mogea, R. Pitopang, M. Schaefer, S. Schwarze, S. G. Sporn, A. Steingrebe, S. S. Tjitrosoedirdjo, S. Tjitrosemito, A. Twele, R. Weber, L. Woltmann, M. Zeller, and T. Tscharntke. 2007. Tradeoffs between income, biodiversity, and ecosystem functioning during tropical rainforest conversion and agroforestry intensification. Proceedings of the National Academy of Sciences of the United States of America 104:4973-4978.

Sundarapandian, S. M., and P. S. Swamy. 1996. Fine root biomass distribution and productivity patterns under open and closed canopies of tropical forest ecosystems at Kodayar in Western Ghats, So uth India. Forest Ecology and Management [For. Ecol. Manage.] 86:181-192.

Tilman, D., D. Wedin, and J. Knops. 1996. Productivity and sustainability influenced by biodiversity in grassland ecosystems. Letters to Nature 379:718-720.

Tscharntke, T., Y. Clough, S. A. Bhagwat, D. Buchori, H. Faust, D. Hertel, D. Hölscher, J. Juhrbandt, M. Kessler, I. Perfecto, C. Scherber, G. Schroth, E. Veldkamp, and T. C. Wanger. 2011. Multifunctional shade-tree management in tropical agroforestry landscapes - A review. Journal of Applied Ecology 48:619-629.

Upadhaya, K., H. N. Pandey, P. S. Law, and R. S. Tripathi. 2005. Dynamics of fine and coarse roots and nitrogen mineralization in a humid subtropical forest ecosystem of northeast India. Biology and Fertility of Soils 41:144-152.

Varik, M., J. Aosaar, I. Ostonen, K. Lõhmus, and V. Uri. 2013. Carbon and nitrogen accumulation in belowground tree biomass in a chronosequence of silver birch stands. Forest Ecology and Management 302:62-70.

Vogt, K. A., D. J. Vogt, and J. Bloomfield. 1998. Analysis of some direct and indirect methods for estimating root biomass and production of forests at an ecosystem level. Plant and Soil 200:71-89. 
West, A. G., S. J. Patrickson, and J. R. Ehleringer. 2006. Water extraction times for plant and soil materials used in stable isotope analysis. Rapid communications in mass spectrometry 20:1317-1321. 


\section{CHAPTER 4}

\section{Patterns in hydraulic architecture from roots to branches in six tropical tree species from cacao agroforestry and their relation to wood density and stem growth}

Martyna M. Kotowska, Dietrich Hertel, Yasmin AbOU RAJAB, Henry BARUs, and Bernhard SCHULDT

Frontiers in Plant Science, 2015, Vol.6, p.1-16 


\subsection{Abstract}

For decades it has been assumed that the largest vessels are generally found in roots and that vessel size and corresponding sapwood area-specific hydraulic conductivity are acropetally decreasing towards the distal twigs. However, recent studies from the perhumid tropics revealed a hump-shaped vessel size distribution. Worldwide tropical perhumid forests are extensively replaced by agroforestry systems often using introduced species of various biogeographical and climatic origins. Nonetheless, it is unknown so far what kind of hydraulic architectural patterns are developed in those agroforestry tree species and which impact this exerts regarding important tree functional traits, such as stem growth, hydraulic efficiency and wood density. We investigated wood anatomical and hydraulic properties of the root, stem and branch wood in Theobroma cacao and five common shade tree species in agroforestry systems on Sulawesi (Indonesia); three of these were strictly perhumid tree species, and the other three tree species are tolerating seasonal drought. The overall goal of our study was to relate these properties to stem growth and other tree functional traits such as foliar nitrogen content and sapwood to leaf area ratio. Our results confirmed a hump-shaped vessel size distribution in nearly all species. Drought-adapted species showed divergent patterns of hydraulic conductivity, vessel density and relative vessel lumen area between root, stem and branch wood compared to wet forest species. Confirming findings from natural oldgrowth forests in the same region, wood density showed no relationship to specific conductivity. Overall, aboveground growth performance was better predicted by specific hydraulic conductivity than by foliar traits and wood density. Our study results suggest that future research on conceptual trade-offs of tree hydraulic architecture should consider biogeographical patterns underlining the importance of anatomical adaptation mechanisms to environment.

Keywords: Shade tree, hydraulic conductivity, wood density, aboveground productivity, foliar nitrogen, perhumid climate, vessel diameter 


\subsection{Introduction}

The water transport pattern in trees is mainly determined by the plant hydraulic architecture, i.e. the spatial distribution of various xylem properties from roots to branches of a tree individual (McCulloh et al. 2010). The hydraulic efficiency of different compartments along the root-to-leaf flow path can be described by the sapwood area-specific hydraulic conductivity $\left(K_{\mathrm{S}}\right)$, which is directly related to the hydraulic resistance of a given position (Tyree and Ewers 1991, McElrone et al. 2004). According to the Hagen-Poiseuille law, even a small increase in mean vessel diameter causes an exponential increase of $K_{\mathrm{S}}$. This anatomical pattern represents the most economical way for a woody plant to enhance the path-length hydraulic conductivity. Independently of the efficiency of the hydraulic system water is transported in a metastable state below its vapor pressure in vascular plants, which makes them vulnerable to the formation of gas embolism. This can impair the transport of water from the soil to the leaves. Particularly wide vessels are not only most conductive but also most prone to the risk of hydraulic failure in form of xylem embolisms (Maherali et al. 2006, Awad et al. 2010, Cai et al. 2010, Hajek et al. 2014), resulting in a trade-off between hydraulic efficiency and cavitation resistance. As one of the basic organizing principles of tree hydraulic architecture it has been postulated that the mean vessel diameter in the xylem tissue generally decreases acropetally from roots to branches ('vessel tapering': Baas 1982, Tyree and Zimmermann 2002, Anfodillo et al. 2013). This principle has stimulated several conceptual models on plant hydraulic architecture during the past 15 years. They state that whole-plant hydraulic conductance dependent on distance to ground in support of the model by West, Brown and Enquist (1999) and Murray's law (McCulloh et al. 2003). Consistent with these predictions it has indeed commonly been observed that the largest vessels along the water flow path are found in roots of trees from temperate or Mediterranean environments (Martinez-Vilalta et al. 2002, Pratt et al. 2007, Domec et al. 2009). However, recent studies in tropical forests in South America (Machado et al. 2007, Fortunel et al. 2013) and Indonesia (Schuldt et al. 2013) have produced contradictory results regarding the paradigm of continuous vessel tapering. Schuldt et al. (2013) supposed that mechanisms reducing cavitation risk may not have been evolved in these moist or perhumid environments where drought stress is normally not apparent.

Forested perhumid regions particularly in the tropics are underrepresented in studies so far and are moreover converted rapidly. Worldwide approximately 27.2 million ha of humid tropical forests have been cleared between 2000 and 2005 (Hansen et al. 2008) mainly for agricultural land use (Achard et al. 2002, FAO and JRC 2012). In South-East Asia, a common driver of deforestation is the conversion of natural forests into cacao (Theobroma cacao) agroforestry systems. Cacao is native to tropical South America (Motamayor et al. 2008) and represents one of the commercially most important perennial cash crops worldwide. Traditionally cacao trees are planted under selectively thinned primary or older secondary forest in Indonesia, but nowadays cultivation is shifting to non-shaded monocultures or 
agroforests with introduced fast-growing legume tree species such as Gliricidia sepium to increase short-term income (Rice and Greenberg 2000). Shade trees in cacao plantations enhance functional biodiversity, carbon sequestration, soil fertility and drought resistance and provide microclimatic benefits such as increased humidity and buffering temperature extremes (Schroth and Harvey 2007, Tscharntke et al. 2011).

Considering the ecological relevance of the anatomical hydraulic properties described above, it is important to note that systematic studies on the ecological wood anatomy and hydraulic architecture of cacao and shade tree species are lacking so far. This is all the more unsatisfying since tropical agroforestry crop and shade tree species often originate from different biomes and possess distinct drought adaptations, but it is unknown so far if this implies differences in the hydraulic strategy of those crop and shade tree species. It is therefore unknown whether cacao and shade tree species in the agroforestry systems with different biogeographical origin have developed similar hydraulic properties as the tree species of the natural forest replaced by those.

A high aboveground biomass production (incl. high crop yield) has been related to several plant functional traits like high stem hydraulic efficiency, high foliar nitrogen content, or low stem wood density (Brodribb et al. 2002, Tyree 2003, Zhang and Cao 2009, Hoeber et al. 2014). Thereby low wood density implying lower hydraulic safety is found to be associated with fast tree growth (Enquist et al. 1999, King et al. 2005, Poorter et al. 2010), while species with dense wood are considered to be more resistant to xylem cavitation due to the commonly assumed relation between wood density and conduit size and thus xylem wall thickness and resistance to cell wall implosion under negative pressure (Jacobsen et al. 2005). Consequently, species with dense wood should show higher hydraulic safety at the cost of lower productivity (Meinzer et al. 2003, Bucci et al. 2004). Nevertheless, several studies, particularly from tropical environments, found wood density decoupled of hydraulic efficiency traits and growth performance (Zhang and Cao 2009, Russo et al. 2010, Fan et al. 2012, Schuldt et al. 2013). It would therefore be interesting to assess whether hydraulic properties and wood density are related to the aboveground performance of crop and shade tree species in cacao agroforests.

In this study we examined the inter-relationship between sapwood area-specific hydraulic conductivity of the root, stem and branch xylem tissue with wood anatomical traits along the water flow path across six common cacao agroforestry tree species with different biogeographical origins from either seasonally dry or perhumid tropical environments growing in cacao agroforests in Central Sulawesi (Indonesia). We moreover wanted to relate aboveground growth performance to hydraulic efficiency, stem wood density, foliar nitrogen content and foliar $\delta^{13} \mathrm{C}$ of these species. We hypothesized (i) that - in contrast to temperate tree species - the largest vessels along the water flow path are found in the stem xylem and not in the roots, (ii) that stem xylem hydraulic properties are unrelated to stem wood density, 
and (iii) that aboveground productivity across species is positively related to vessel size and hydraulic conductivity.

\subsection{Material and methods}

Study site, species and sampling

The study was carried out in a cacao agroforestry located in the Kulawi Valley, Bolabapu District, Central Sulawesi, Indonesia (S 01 ${ }^{\circ} 55.9^{\prime}$ E $120^{\circ} 02.2^{\prime}$, elevation $571 \mathrm{~m}$ a.s.1.) in May 2012. The climate of the study region is perhumid without a distinct dry season. Mean annual temperature recorded for the study area by Moser et al. (2010) is $25.5{ }^{\circ} \mathrm{C}$ and mean annual precipitation is $2092 \mathrm{~mm}$ between 2002 and 2006. For the study, a cacao agroforestry plot with multi-species shade tree layer was selected from a larger number of preselected cacao agroforestry plots of a different investigation that were found to be representative in terms of management, aboveground structure and topographical patterns for this region. Caution was taken during the selection process that the plot was far enough above the groundwater table to guarantee that the trees had no direct access to this water source. All trees in the agroforest were planted simultaneously around 25 years ago.

Theobroma cacao L. (Malvaceae) originating from rainforests of lowland northern South America and five common shade tree species were studied: Leucaena leucocephala (Lam.) de Wit and Gliricidia sepium (Jacq.) Steud. (both Fabaceae), which are introduced species from seasonal dry forest areas of Central America. The three other species represent native origins: Gnetum gnemon L. (Gnetaceae), the short-term drought-tolerating Erythrina subumbrans (Hassk.) Merill (Fabaceae) and the strictly perhumid species Durio zibethinus. Murr. (Malvaceae). In the following we have grouped the species according to their drought tolerance as perhumid (T. cacao, D. zibethinus, G. gnemon) and seasonal (G. sepium, L. leucocephala, E. subumbrans). All species have diffuse-porous wood with G. gnemon being a gymnosperm bearing vessels structurally similar to angiosperms (Carlquist 1994, Fisher and Ewers 1995). We chose six tree replicates of each species with a diameter and height representative for the whole agroforestry.

For each tree three sun-exposed upper-crown branches and three topsoil root segments (diameter 6-14 mm; length 25-35 cm) were collected as well as one stem core of $5 \mathrm{~cm}$ length per tree taken with an increment corer (Haglöf, Långsele, Sweden) at $130 \mathrm{~cm}$ stem height. To ensure species identity the roots were traced back to the tree stem. In order to avoid microbial growth in the extracted tree organs, samples were stored in polyethylene tubes filled with water containing a sodium-silver chloride complex (Micropur Katadyn, Wallisellen, Switzerland). The samples were kept cool at $4{ }^{\circ} \mathrm{C}$ and the conductivity measurements took place not more than 7 days after collection. 


\section{Wood density, aboveground biomass and productivity}

Wood density, defined as oven-dry weight over wet volume, was measured for each stem core. The fresh volume of each sample was determined by Archimedes' principle. Samples were then oven dried for $48 \mathrm{~h}$ at $105{ }^{\circ} \mathrm{C}$ and dry mass recorded.

Aboveground biomass of the trees was calculated using the allometric equation of Chave et al. (2005) for tropical wet stands as: $\mathrm{AGB}=\exp \left(-2.187+0.916 \times \ln \left(\mathrm{WD} \times \mathrm{DBH}^{2} \times \mathrm{H}\right)\right)$, where AGB is the estimated above-ground biomass $(\mathrm{kg}), \mathrm{DBH}$ the trunk diameter at $130 \mathrm{~cm}$ height $(\mathrm{cm}), \mathrm{H}$ the total tree height $(\mathrm{m})$, and WD the stem wood density $\left(\mathrm{g} \mathrm{cm}^{-3}\right)$. Since we obtained proper data on tree height only at the beginning of the study, we used stem basal area increment (BAI, $\mathrm{cm}^{2} \mathrm{yr}^{-1}$ ) determined over a period of 12 month using dendrometer tapes (UMS GmbH, München, Germany) as indicator for aboveground productivity. However, it has been shown that above-ground biomass increment and basal area increment are very closely related in tropical trees (Hoeber et al. 2014). For T.cacao, G. sepium and D. zibethinus six tree replicates were monitored, whereas data from just three G. gnemon, two $L$. leucocephala and one of E. subumbrans were available for BAI.

\section{Leaf morphological and chemical properties}

From each branch segment harvested for the hydraulic and anatomical measurements, all distal leaves were stripped off and oven-dried at $70{ }^{\circ} \mathrm{C}$ for $48 \mathrm{~h}$ to determine leaf dry weight. Specific leaf area (SLA, $\mathrm{cm}^{2} \mathrm{~g}^{-1}$ ) values were determined using data from nine additional branches per species where leaf surface areas were measured with the WinFOLIA software (Régent Instruments, Quebec, Canada). Total leaf area per branch segment $\left(A_{\mathrm{L}}, \mathrm{m}^{2}\right)$ was calculated by dividing dry weight through species-specific SLA values. Subsequently, leaf samples were grounded and analyzed for their foliar concentrations of $\mathrm{C}$ and $\mathrm{N}$ and for their foliar signatures of $\delta^{13} \mathrm{C}$ in the leaf bulk tissue with a Delta plus isotope mass spectrometer (Finnigan MAT, Bremen, Germany), a Conflo III interface (Thermo Electron Coorperation, Bremen, Germany) and a NA2500 elemental analyzer (CE-Instruments, Rodano, Milano, Italy) using standard $\delta$ notion: $\delta=\left(R_{\text {sample }} / R_{\text {standard }}-1\right) \times 1000(\%)$ in the laboratory for stable isotope measurements (KOSI) at the University of Göttingen.

\section{Empirical conductivity measurements}

Hydraulic conductivity of one to three root and branch segments per tree was empirically measured using the method described by Sperry et al. (1988). In total, 44 root and 39 branch segments were analyzed (mean root segment length \pm SE: $291 \pm 7.0 \mathrm{~mm}$ and diameter: $7.87 \pm 0.25 \mathrm{~mm}$; mean branch segment length: $308 \pm 4.3 \mathrm{~mm}$ and diameter: $9.12 \pm 0.29 \mathrm{~mm}$ ). All segments were recut under water with a razor blade, small lateral roots and branches cutoff and sealed with quick-drying superglue (Loctite 431, Henkel, Düsseldorf, Germany) and activator (Loctite 7452 Aktivator, Henkel, Düsseldorf, Germany) that function on wet materials. Afterwards, segments were attached under water to the tubing system of the 
conductivity apparatus, where the pressure difference of $6 \mathrm{kPa}$ was generated by a $60 \mathrm{~cm}$ high water column. De-ionized water with a sodium-silver chloride complex $\left(16 \mu \mathrm{g} \mathrm{L}^{-1} \mathrm{Ag}, 8 \mathrm{mg}\right.$ $\mathrm{L}^{-1} \mathrm{NaCl}$, Micropur katadyn, Wallisellen, Switzerland) was used as measuring solution in order to avoid microbial growth in the tubing system, a common problem in tropical environments. While comparing our data with conductivities determined by other solutions, it has to be considered that different perfusion solutions can affect hydraulic conductivity (Espino and Schenk 2011). The solution was passed through a $0.2 \mu \mathrm{m}$ membrane filter (Maxi Capsule, Pall Corp., USA) and each sample measured three times in row and flushed with the measuring solution for $5 \mathrm{~min}$ at $120 \mathrm{kPa}$ in between each measurement to remove potential emboli. The hydraulic conductivity $\left(K_{\mathrm{h}}^{\mathrm{emp}}, \mathrm{kg} \mathrm{m} \mathrm{s}^{-1} \mathrm{MPa}^{-1}\right)$ was calculated as $K_{\mathrm{h}}=(\Delta \mathrm{V} / \Delta \mathrm{t})$ $\times(1 / \Delta \mathrm{P})$, where 1 is the length of the segment $(\mathrm{m}), \Delta \mathrm{P}$ the pressure difference applied to the segment (MPa), $\Delta \mathrm{V}$ the amount of water flowing out of the segment $(\mathrm{kg})$, and $\Delta \mathrm{t}$ the time interval of measurement (s).

Segments of the branches and roots used for conductivity measurements were planed with a sliding microtome (G.S.L.1, WSL, Birmensdorf, Switzerland) to obtain high-quality top view images with a stereo-microscope (SteREOV20, Carl Zeiss MicroImaging GmbH, Göttingen, Gemany) and total cross-sectional $\left(A_{\text {cross }}, \mathrm{mm}^{2}\right)$ and xylem cross-sectional area $\left(A_{\text {xylem }}, \mathrm{mm}^{2}\right)$ analyzed with ImageJ (v1.44p, http://rsb.info.nih.gov/ij). Subsequently, for each species a regression analysis between $A_{\text {cross }}$ and $A_{\text {xylem }}$ was carried out (Table A 5.1). Empirical sapwood area-specific hydraulic conductivity $\left(K_{\mathrm{S}}{ }^{\mathrm{emp}}, \mathrm{kg} \mathrm{m}^{-1} \mathrm{MPa}^{-1} \mathrm{~s}^{-1}\right)$ was calculated by dividing $K_{\mathrm{h}}{ }^{\mathrm{emp}}$ by the calculated mean xylem cross-sectional area without pith and bark by applying the species-specific regression coefficients, and empirical leaf areaspecific hydraulic conductivity $\left(K_{\mathrm{L}}^{\mathrm{emp}}, \mathrm{kg} \mathrm{m}^{-1} \mathrm{MPa}^{-1} \mathrm{~s}^{-1}\right)$ by dividing $K_{\mathrm{h}}$ by the total supported leaf area $\left(A_{\mathrm{L}}\right)$.

\section{Vascular anatomy}

For the cross-sectional xylem anatomical analysis, $3 \mathrm{~cm}$ of the basipetal end of each root or branch segment used for empirical conductivity measurements was stained with safranin (1\% in 50\% ethanol, Merck, Darmstadt, Germany) and 10-20 $\mu \mathrm{m}$ semi-thin discs cut with a sliding microtome (G.S.L.1, WSL, Birmensdorf, Switzerland). For stem wood anatomy the outermost $4 \mathrm{~cm}$ of the increment core were used. Photographs of the cross-sectional cuts were taken with a stereo-microscope with an automatic stage equipped with a digital camera (SteREOV20, Carl Zeiss MicroImaging GmbH, Göttingen, Gemany) at 100x magnification. Per sample, 32 up to 107 single images were stitched together to obtain the whole cross-sectional area. Image processing was done with Adobe Photoshop CS6 (version 13.0.1, Adobe Systems Incorporated, USA) and ImageJ (version 1.47, http://rsb.info.nih.gov/ij) using the particle analysis-function for estimating vessel density $\left(\mathrm{VD}, \mathrm{n} \mathrm{mm}^{-1}\right)$, the idealized vessels diameter (d) from major $(a)$ and minor $(b)$ vessel radii using the equation given by White (1991) as $d=\left(\left(32 \times(a \times b)^{3}\right) /\left(a^{2}+b^{2}\right)\right)^{1 / 4}$, and cumulative vessels lumen area $\left(A_{\text {lumen }}, \mathrm{m}^{2}\right)$. Single vessel 
diameters $(d)$ were used to calculate the hydraulically weighted vessel diameter $\left(d_{\mathrm{h}}\right)$ according to Sperry et al. (1994) as $d_{\mathrm{h}}=\Sigma d^{4} / \Sigma d^{5}$. For these measurements all vessels of a cross section were analyzed, yielding 110 to 3,600 measured vessel per species and organ. The theoretical hydraulic conductivity $\left(K_{\mathrm{h}}^{\text {theo }}\right)$ of a segment can be calculated based on Hagen-Poiseuille's law as $\left.K_{\mathrm{h}}^{\text {theo }}=\left(\pi \times \Sigma \mathrm{r}^{4}\right) / 8 \eta\right) \times \rho$, where $\mathrm{r}$ is the vessel radius, $\eta$ the viscosity $\left(1.002 \times 10^{-3} \mathrm{~Pa}\right.$ s) and $\rho$ the density of water $\left(998.2 \mathrm{~kg} \mathrm{~m}^{-3}\right)$, both at $20{ }^{\circ} \mathrm{C}$. Theoretical sapwood area-specific hydraulic conductivity $\left(K_{\mathrm{S}}{ }^{\text {theo }}, \mathrm{kg} \mathrm{m}^{-1} \mathrm{MPa}^{-1} \mathrm{~s}^{-1}\right)$ was obtained from $K_{\mathrm{h}}{ }^{\text {theo }}$ by dividing through the microscopically determined xylem cross-sectional area without bark and pit, and theoretical leaf area-specific hydraulic conductivity $\left(K_{\mathrm{L}}^{\text {theo }}, \mathrm{kg} \mathrm{m}^{-1} \mathrm{MPa}^{-1} \mathrm{~s}^{-1}\right)$ by division of $K_{\mathrm{h}}^{\text {theo }}$ by the total supported leaf area $\left(A_{\mathrm{L}}\right)$.

\section{Statistical analyses}

A principal-component analysis (PCA) was done to evaluate how aboveground growth performance, wood anatomical and leaf traits are associated among each other using the package CANOCO, version 4.5 (Biometris, Wageningen, the Netherlands). The matrix species factors were lumen area $\left(A_{\text {lumen }}\right)$, vessel density (VD), hydraulically weighted vessel diameter $\left(d_{\mathrm{h}}\right)$, stem basal increment (BAI), empirical $\left(K_{\mathrm{S}}{ }^{\mathrm{emp}}\right)$ as well as theoretical hydraulic conductivity $\left(K_{\mathrm{S}}^{\text {theo }}\right)$. All other statistical calculations were done with the R software package, version 3.1.0 (R Development Core Team, 2014). Pearson correlations were calculated for all pairwise combinations of wood anatomical properties, wood density and hydraulic traits. In case of non-linear relationships where the data are presented on a log-linear scale, the data were $\log 10$ transformed to achieve normal distribution before further statistical analyses were conducted. Comparisons of hydraulic and leaf traits among organs were conducted using mixed linear models (lme, package: 'nlme' and lm package: 'stats') with species as random factor to account for pseudoreplication. Predicted random effects and residuals of the models were checked for normal distribution and homoscedasticity using diagnosis plots and dependent variables were log-transformed and/or variance functions (varIdent or varExp) were used (Pinheiro and Bates 2000) when necessary. Subsequently, multiple comparison tests between group means were tested post-hoc with Tukey HSD tests (glht package: 'multcomp'). In case of heteroscedasticity an adjusted statistical framework for simultaneous inference and robust covariance estimators (Herberich et al. 2010) was used to account for different variances between groups. To test the best predictor for aboveground growth performance we applied stepwise backward model selection (step.AIC, package: 'MASS') to identify the most parsimonious model, defined as the model with the lowest AIC (Akaike information criterion) score (Burnham and Anderson 2002) including $K_{\mathrm{S}}^{\text {theo }}, \mathrm{WD}, \mathrm{N}_{\text {leaf }}, \delta^{13} \mathrm{C}$ as well as species affiliation (whether it is perhumid or seasonal) and their interactions as explanatory variables. 
Table 4.1: List of major variables with definition and units employed.

\begin{tabular}{lll}
\hline Symbol & Unit & Definition \\
\hline \hline $\mathrm{H}$ & $\mathrm{cm}$ & Tree height \\
$\mathrm{DBH}$ & $\mathrm{cm}$ & Diameter at breast height \\
$\mathrm{AGB}$ & $\mathrm{kg}$ & Aboveground biomass \\
BAI & $\mathrm{cm}^{2} \mathrm{yr}^{-1}$ & Basal area increment \\
$\mathrm{WD}$ & $\mathrm{g} \mathrm{cm}^{-3}$ & Wood density \\
$d$ & $\mu \mathrm{m}$ & Vessel diameter \\
$d_{\mathrm{h}}$ & $\mu \mathrm{m}$ & Hydraulically weighted vessel diameter \\
VD & $\mathrm{n} \mathrm{mm}^{-2}$ & Vessel density \\
$A_{\text {lumen }}$ & $\%$ & Relative vessel lumen area (lumen to sapwood area ratio) \\
$A_{\text {cross }}$ & $\mathrm{mm}^{2}$ & Branch cross sectional area \\
$A_{\text {xylem }}$ & $\mathrm{mm}^{2}$ & Branch sapwood area \\
$K_{\mathrm{S}}^{\text {emp }}$ & $\mathrm{kg} \mathrm{m}^{-1} \mathrm{MPa}^{-1} \mathrm{~s}^{-1}$ & Empirical sapwood area-specific hydraulic conductivity \\
$K_{\mathrm{S}}^{\text {theo }}$ & $\mathrm{kg} \mathrm{m}^{-1} \mathrm{MPa}^{-1} \mathrm{~s}^{-1}$ & Theoretical sapwood area-specific hydraulic conductivity \\
$K_{\mathrm{L}}^{\text {emp }}$ & $10^{-4} \mathrm{~kg} \mathrm{~m}^{-1} \mathrm{MPa}^{-1} \mathrm{~s}^{-1}$ & Empirical leaf area-specific hydraulic conductivity \\
$K_{\mathrm{L}}^{\text {theo }}$ & $10^{-4} \mathrm{~kg} \mathrm{~m}^{-1} \mathrm{MPa}^{-1} \mathrm{~s}^{-1}$ & Theoretical leaf area-specific hydraulic conductivity \\
$N_{\text {leaf }}$ & $\mathrm{g} \mathrm{kg}^{-1}$ & Foliar mass-specific nitrogen content \\
$\mathrm{SLA}$ & $\mathrm{cm}^{2} \mathrm{~g}^{-1}$ & Specific leaf area \\
$\mathrm{HV}$ & $10^{-4} \mathrm{~m}^{2} \mathrm{~m}^{-2}$ & Sapwood to leaf area ratio (Huber value) \\
$\delta^{13} \mathrm{C}$ & $\% 0$ & Carbon isotope signature \\
\hline
\end{tabular}

\subsection{Results}

\section{Tree size and aboveground growth performance}

The variability in mean above-ground biomass (AGB) between the studied species was high, ranging between $16.9 \mathrm{~kg}$ in $T$. cacao and $888.2 \mathrm{~kg}$ in L. leucocephala reflecting marked differences in height and diameter between the pruned T. cacao and G. sepium, and the other four shade tree species (Table 4.2).

Table 4.2: Tree height $(\mathrm{H})$, diameter at breast height (DBH), wood density (WD), aboveground biomass (AGB) and basal area increment (BAI) of the six tree species in cocoa agroforests. Shown values are means $\pm \mathrm{SE}$ and the number of investigated tree individuals. * For BAI, however, only three tree individuals of Gnetum gnemon, two of Leucaena leucocephala, and one of Erythrina subumbrans were available (see Material and Methods section).

\begin{tabular}{|c|c|c|c|c|c|c|c|}
\hline Species & Code & $\mathbf{n}$ & $\begin{array}{r}\mathbf{H} \\
(\mathbf{m}) \\
\end{array}$ & $\begin{array}{l}\text { DBH } \\
(\mathrm{cm}) \\
\end{array}$ & $\begin{array}{c}\text { WD } \\
\left(\mathrm{g} \mathrm{cm}^{-3}\right)\end{array}$ & $\begin{array}{l}\text { AGB } \\
(\mathrm{kg}) \\
\end{array}$ & $\begin{array}{c}\text { BAI } \\
\left(\mathrm{cm}^{2} \mathrm{yr}^{-1}\right) \\
\end{array}$ \\
\hline \multicolumn{8}{|l|}{ Perhumid } \\
\hline Theobroma cacao & Th_ca & 6 & $5.83 \pm 0.37$ & $11.36 \pm 0.45$ & $0.398 \pm 0.007$ & $16.89 \pm 2.14$ & $6.51 \pm 1.92$ \\
\hline Durio zibethinus & Du_zi & 6 & $14.10 \pm 1.44$ & $25.56 \pm 4.03$ & $0.430 \pm 0.019$ & $230.65 \pm 72.72$ & $67.99 \pm 20.03$ \\
\hline \multicolumn{8}{|l|}{ Seasonal } \\
\hline Gliricidia sepium & Gl_se & 6 & $10.90 \pm 0.56$ & $11.68 \pm 0.51$ & $0.601 \pm 0.029$ & $45.75 \pm 3.67$ & $19.02 \pm 4.83$ \\
\hline Leucaena leucocephala & Le_le & 6 & $13.75 \pm 2.07$ & $36.30 \pm 8.61$ & $0.609 \pm 0.010$ & $888.20 \pm 320.79$ & $87.61 \pm 28.87$ \\
\hline Erythrina subumbrans & Er_su & 6 & $10.06 \pm 0.58$ & $33.05 \pm 2.29$ & $0.273 \pm 0.008$ & $162.03 \pm 20.88$ & $10.18^{*}$ \\
\hline
\end{tabular}


L. leucocephala was on average more than two times higher and larger compared to T. cacao; the other four species ranged between these two extremes even though all trees were planted at the same time. Stem wood density (WD) varied by a factor of two across the six tree species with E. subumbrans showing the lowest WD and G. sepium and L. leucocephala showing the highest WD values. BAI numbers were thus very different across the six tree species and ranged from 6.5 and $10.2 \mathrm{~cm}^{2} \mathrm{yr}^{-1}$ in T. cacao and E. subumbrans, respectively, to 68 and $88 \mathrm{~cm}^{2} \mathrm{yr}^{-1}$ in D. zibethinus and L. leucocephala, respectively. AGB was found to be a very good predictor for the annual basal area increment (BAI) amongst all species (Figure 4.1).

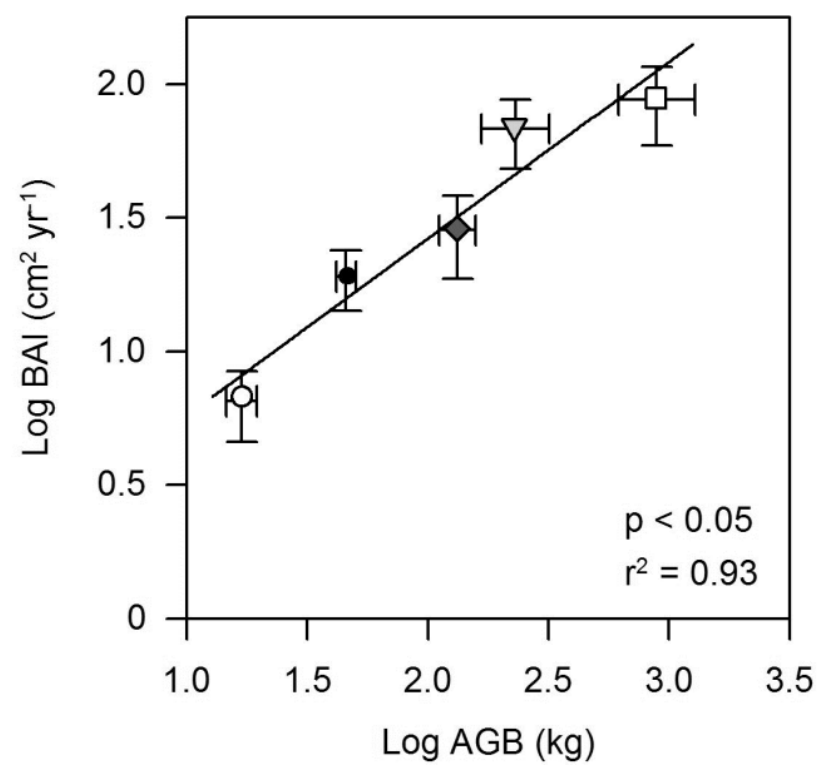

Figure 4.1: Relationship between stem basal area increment (BAI) of cacao and four shade tree species and aboveground biomass (AGB). Each symbol represents mean values for each tree species ( $C$ Th_ca; $\nabla$ Du_zi; $\diamond$ Gl_se; $\ulcorner$ Le_le; $\bullet$ Gn_gn). Error bars indicate \pm SE.

Changes in hydraulic conductivity along the water flow path

The empirically determined sapwood area-specific hydraulic conductivity $\left(K_{\mathrm{S}}^{\mathrm{emp}}\right)$ of root segments differed by a factor of 100 across species with $E$. subumbrans showing the highest values by far, whereas the smallest values were observed in roots of $T$. cacao (Figure 4.2, Table A 4.2). 

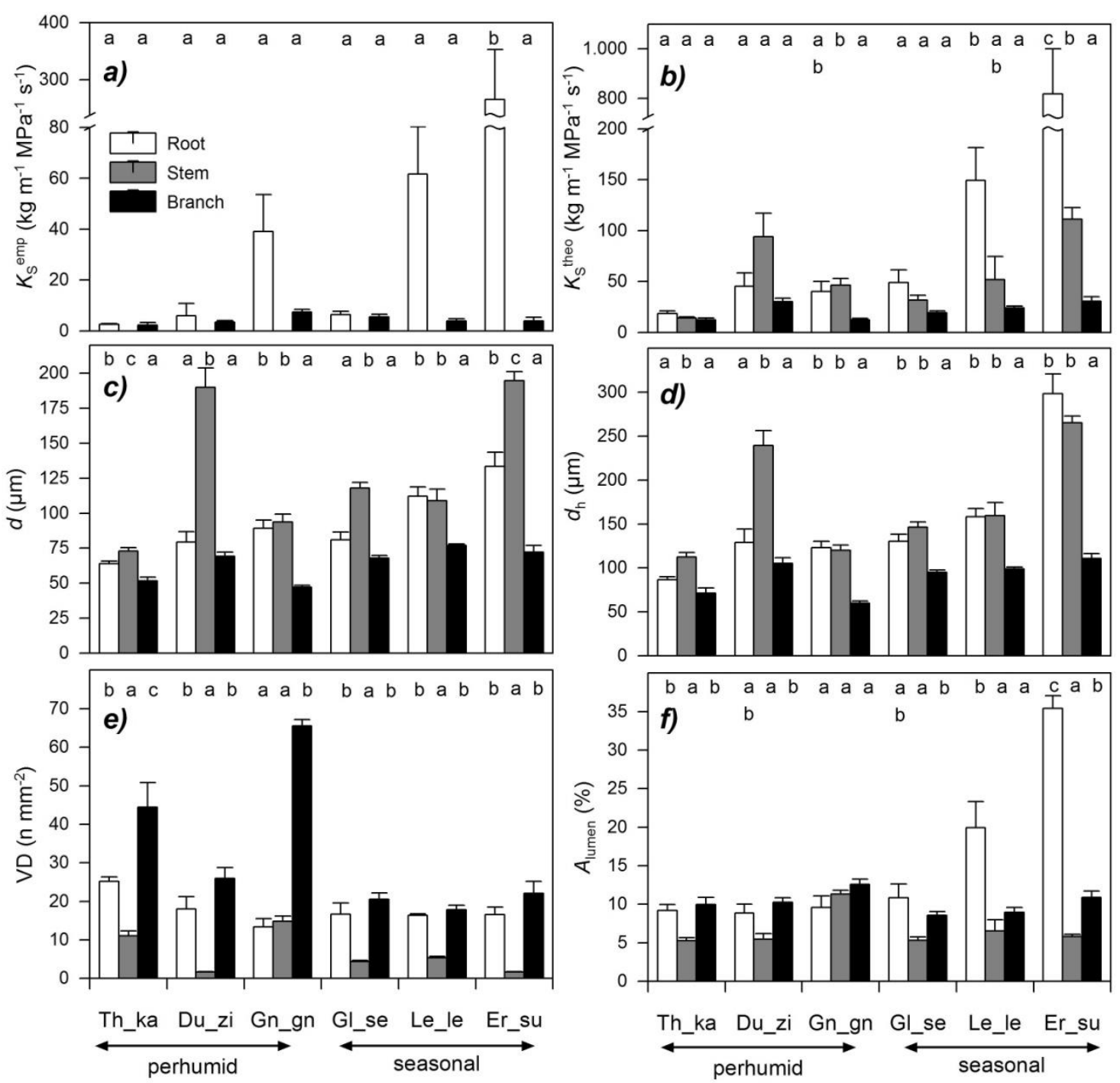

Figure 4.2: Hydraulic characteristics - a) empirical sapwood area-specific hydraulic conductivity $\left(K_{\mathrm{S}}^{\text {emp }}\right)$, b) theoretically calculated sapwood area-specific hydraulic conductivity $\left(K_{\mathrm{S}}^{\text {theo }}\right)$, c) vessel diameter $(d)$, d) hydraulically weighted vessel diameter $\left(d_{\mathrm{h}}\right)$, e) vessel density (VD), and f) lumen area $\left(A_{\text {lumen }}\right)$ - of six cacao agroforestry species (Th_ca; Du_zi; Gn_gn; Gl_se; Le_le; Er_su) among root (white bars), stem (grey bars) and branch xylem (black bars). Error bars indicate \pm SE.

The differences in $K_{\mathrm{S}}^{\mathrm{emp}}$ of branches across species were much less pronounced (2.3 to 7.4 $\mathrm{kg} \mathrm{m}^{-1} \mathrm{MPa}^{-1} \mathrm{~s}^{-1}$ ) with G. gnemon showing the highest and $T$. cacao the lowest numbers. Overall, root segments always showed higher hydraulic conductivities than branches ('lme'; $p$ $<0.001$ ). Furthermore, $K_{\mathrm{S}}{ }^{\text {emp }}$ values (in both root and branch segments) were always smaller than the theoretically calculated hydraulic conductivity $\left(K_{\mathrm{S}}^{\text {theo }}\right)$ as derived from vessel diameters by Hagen-Poiseuille's law. Even though branch and root segments around $30 \mathrm{~cm}$ lengths were used, probably open-cut vessels could not be avoided particularly for root segments of E. subumbrans. However, mean $K_{\mathrm{S}}{ }^{\text {emp }}$ values reached $9-45 \%$ of respective $K_{\mathrm{S}}^{\text {theo }}$ values indicating that open-cut vessels were negligible for most species, except for G. gnemon where $50-81 \%$ of respective $K_{\mathrm{S}}{ }^{\text {theo }}$ values were measured (Figure 4.2). Empirically measured and calculated specific conductivity in root segments showed a positive linear relationship ('lme'; $\mathrm{p}<0.001$ ), but not for branch segments ('lme'; $\mathrm{p}=0.71$ ). 
Anatomical differences across species in root, stem, and branch wood properties
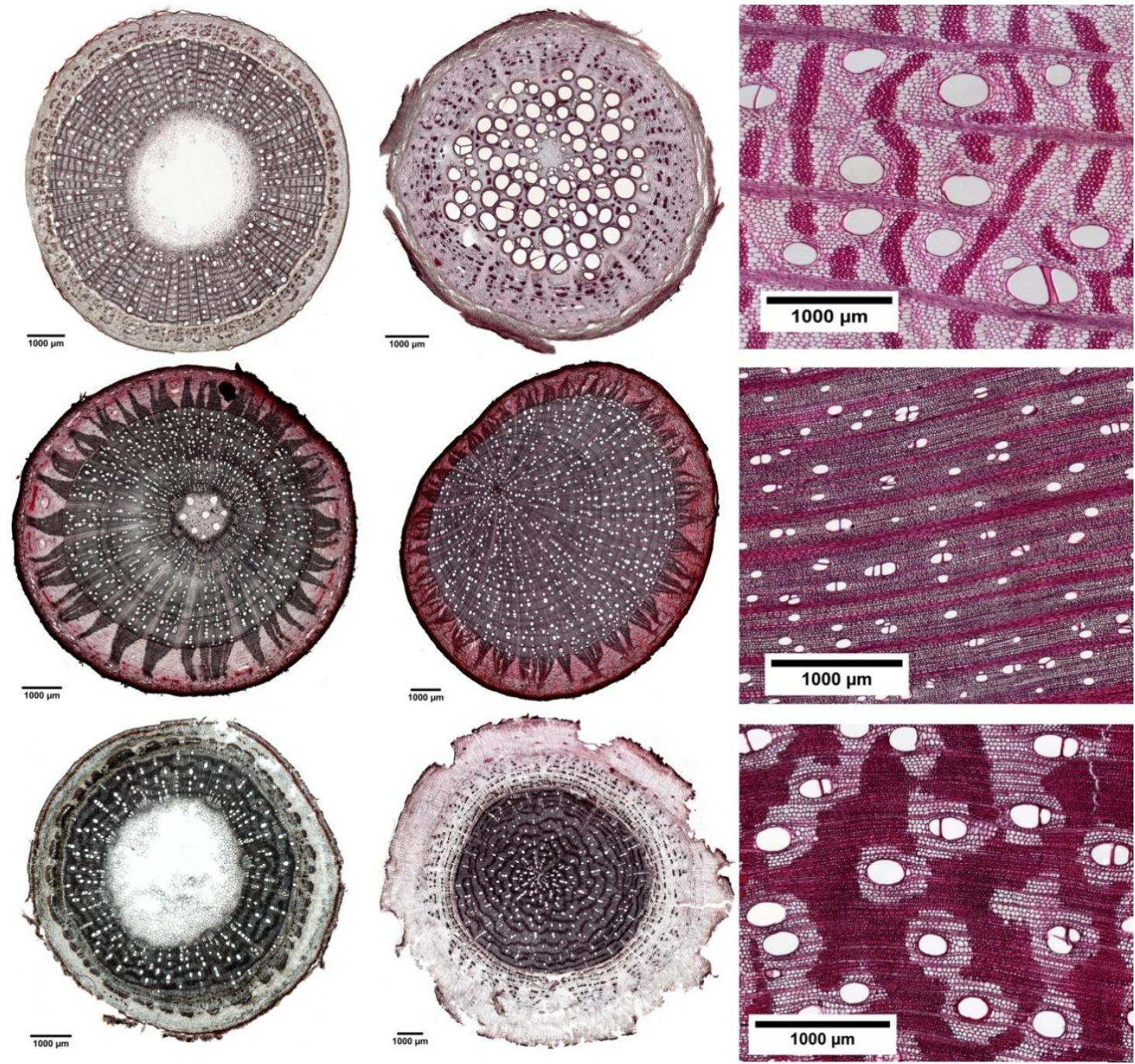

Figure 4.3: Cross-sections of different tree parts along the flow path: branch (left row), roots (middle row) and stems (right row) for three common tree species from cocoa agroforests in Sulawesi, Indonesia. Erythrina subumbrans (upper line), Theobroma cacao (middle line) and Gliricidia sepium (lower line). The scale bars are presented in the figures and black bars represent $1000 \mu \mathrm{m}$.

We found considerable variation in wood anatomical and derived hydraulic traits along the flow path from root, to stem and branch wood for all six species. Exemplary pictures for this variation from three of the species are given in Figure 4.3. In four of the six species average vessel diameter $(d)$ was significantly largest in the stem and not in the root wood; in the remaining two species $d$ was comparable between root and stem wood (Figure 4.2). Along the flow path smallest vessels were always observed in the branch wood of all species with the exception of D. zibethinus (Figure 4.2). The same pattern was observed for the hydraulically weighted vessel diameter $\left(d_{\mathrm{h}}\right)$ for branch wood, while the differences in $d_{\mathrm{h}}$ between root and stem wood were only significant in T. cacao and D. zibethinus. In general, several wood anatomical and derived hydraulic traits allowed a grouping between the three perhumid tree species originating from strictly wet tropical environments, and the three 
seasonal tree species reported to tolerate moderate droughts. As mentioned above, $d_{\mathrm{h}}$ was not significantly higher in stem than in root wood for the three seasonal tree species, and vessel density (VD) was comparable between root and branch wood and did not differ significantly. On the other hand, highest vessel densities were observed in the branch wood of all perhumid tree species, although differences were only significant in two of the three species. However, when comparing the two groups (perhumid vs. seasonal) significant differences were found ('lme'; $\mathrm{p}<0.001$ ). In general, VD varied considerably between the organs and species as well and was found to decrease in the order branch - root - stem across all six species (Figure 4.2). Variation in VD numbers was lowest (factor $<2$ ) in the root xylem and highest (factor $>10$ ) in the stem xylem. VD decreased exponentially with increasing vessels diameter; we therefore concentrate on changes in $d$ along the flow path in the following (Figure 4.4).

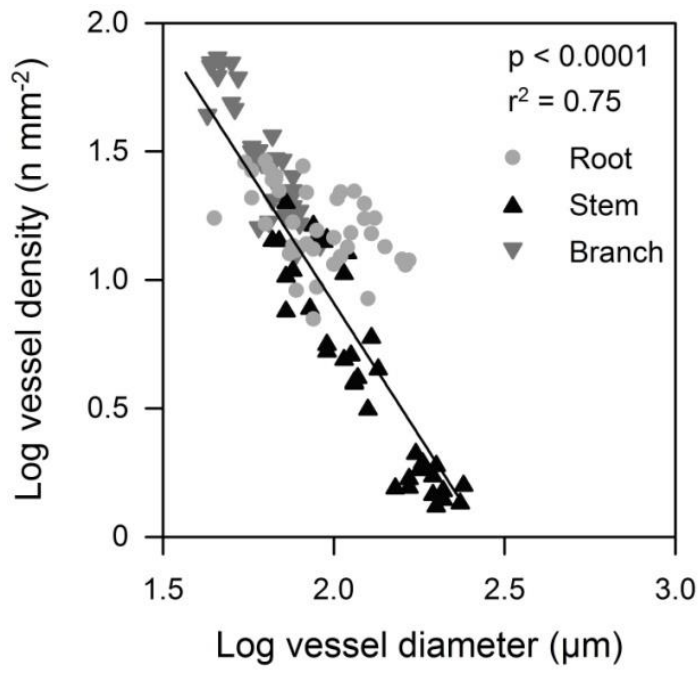

Figure 4.4: Mean vessel diameter in relation to vessel density in tree organs (roots, stems and branches) along the flow path for the six tree species.

Relative vessel lumen area $\left(A_{\text {lumen }}\right)$, i.e. the ratio of lumen to sapwood area, was lowest in the stem wood in all species except of G. gnemon (Figure 4.2). Root and branch wood showed therefore higher $A_{\text {lumen }}$ values that tended to show similar dimensions with the exception of the seasonal tree species that showed significantly higher $A_{\text {lumen }}$ values in the root segments.

When concentrating on hydraulic properties we found a similar pattern in $K_{\mathrm{S}}^{\text {theo }}$, where hydraulic conductivity was highest in roots of seasonal tree species ('lme'; $p<0.001$ ), while there is no overall significant difference between the root and stem wood in the perhumid species $(\mathrm{p}>0.05)$. 


\section{Leaf morphological, chemical and hydrological properties}

Specific leaf area (SLA) of sun-exposed leaves was higher by roughly a factor of two in $E$. subumbrans, G. sepium and L. leucocephala than in D. zibethinus, T. cacao, and G. gnemon (Table 4.3). The sapwood to leaf area ratio ('Huber value', HV) of the sun-lit branch samples was lowest in G. sepium and T. cacao, and highest in E. subumbrans. Empirical leaf areaspecific hydraulic conductivity $\left(K_{\mathrm{L}}^{\mathrm{emp}}\right)$ in these branch samples showed a large variation across species ranging from $1.210^{-4} \mathrm{~kg} \mathrm{~m}^{-1} \mathrm{MPa}^{-1} \mathrm{~s}^{-1}$ in $T$. cacao over $4.3-4.810^{-4} \mathrm{~kg} \mathrm{~m}^{-1}$ $\mathrm{MPa}^{-1} \mathrm{~s}^{-1}$ in D. zibethinus, G. sepium, E. subumbrans, and L. leucocephala to $14.210^{-4} \mathrm{~kg} \mathrm{~m}^{-1}$ $\mathrm{MPa}^{-1} \mathrm{~s}^{-1}$ in $G$. gnemon. The variation in theoretical leaf area-specific hydraulic conductivity $\left(K_{\mathrm{L}}{ }^{\text {theo }}\right)$ derived from the wood anatomical properties was less pronounced. Lowest values were found in $T$. cacao, followed by G. sepium, while the other four tree species had ca. 2-5 times higher $K_{\mathrm{L}}{ }^{\text {theo }}$ values (Table 4.3).

Table 4.3: Leaf morphological, hydraulic, and chemical properties of the six investigated tree species. Values are means $\pm \mathrm{SE}$; the number of investigated trees and measured samples (in parentheses) is also given. Different small letters indicate differences between species. See Table 4.1 for definition of abbreviations.

\begin{tabular}{|c|c|c|c|c|c|c|c|}
\hline Species & $\begin{array}{c}\text { SLA } \\
\left(\mathrm{cm}^{2} \mathrm{~g}^{-1}\right)\end{array}$ & $\begin{array}{c}\text { HV } \\
\left(\mathrm{m}^{2} \mathrm{~m}^{-2}\right)\end{array}$ & & $\begin{array}{c}K_{\mathrm{L}}{ }^{\mathrm{emp}} \times 10^{-4} \\
\left(\mathrm{~kg} \mathrm{~m}^{-1} \mathrm{MPa}^{-1} \mathrm{~s}^{-1}\right)\end{array}$ & $\begin{array}{c}K_{\mathrm{L}}^{\text {theo }} \times 10^{-4} \\
\left(\mathrm{~kg} \mathrm{~m}^{-1} \mathrm{MPa}^{-1} \mathrm{~s}^{-1}\right)\end{array}$ & $\begin{array}{c}N_{\text {leaf }} \\
\left(\mathrm{g} \mathrm{kg}^{-1}\right)\end{array}$ & $\begin{array}{r}\delta^{13} C \\
(\%)\end{array}$ \\
\hline \multicolumn{8}{|l|}{ Perhumid } \\
\hline D. zibethinus & $124.74 \pm 12.19$ a $3(9)$ & $3.07 \pm 0.99 \mathrm{a}$ & 6 & $4.27 \pm 0.92$ a 6 & $51.11 \pm 13.18$ b 6 & $2.28 \pm 0.25$ a $6(18)$ & $-29.87 \pm 0.46$ a $6(18)$ \\
\hline G. gnemon & $146.75 \pm 5.35$ a $3(9)$ & $2.90 \pm 0.71 \mathrm{a}$ & 6 & $14.23 \pm 4.22$ b 6 & $29.81 \pm 10.57 \mathrm{ab} 6$ & $2.69 \pm 0.21$ ab $6(18)$ & $-29.83 \pm 0.42$ a $6(18)$ \\
\hline G. sepium & $271.48 \pm 19.74$ b $3(9)$ & $1.72 \pm 0.26 \mathrm{a}$ & 6 & $4.29 \pm 1.09$ a 6 & $13.31 \pm 1.97 \mathrm{ab} 6$ & $3.35 \pm 0.17$ bc $6(18)$ & $-29.09 \pm 0.19$ a $6(18)$ \\
\hline L. leucocephala & $293.2 \pm 21.3$ b $3(6)$ & $2.07 \pm 0.52 \mathrm{a}$ & 6 & $4.79 \pm 0.81$ a 6 & $47.16 \pm 11.23 \mathrm{ab} 6$ & $3.59 \pm 0.12$ c $6(18)$ & $-27.93 \pm 0.08$ c $6(18)$ \\
\hline E. subumbrans & $264.38 \pm 11.11$ b $3(9)$ & $3.91 \pm 1.40 \mathrm{a}$ & 6 & $4.76 \pm 1.69$ a 6 & $38.25 \pm 14.05$ ab 6 & $3.59 \pm 0.14$ c $6(18)$ & $-27.89 \pm 0.28$ bc $6(18)$ \\
\hline
\end{tabular}

Mass-specific foliar nitrogen concentration ( $\left.N_{\text {leaf }}\right)$ was lowest in $T$. cacao, medium high in $D$. zibethinus and G. gnemon, and highest in the three seasonal species G. sepium, $L$. leucocephala and E. subumbrans (Table 4.3). Variation in leaf carbon isotopic composition was rather small. The two species E. subumbrans and L. leucocephala revealed a ca. 1.0-1.8 higher $\delta^{13} \mathrm{C}$ value than the four other species that did not show significant differences in this variable.

Interrelationships between vascular properties, tree stem growth and hydraulic conductivity A principal component analysis (PCA) on the inter-relationships between the investigated traits explained a large proportion of the total variance of the data set along the first four axes (Table 4.4). 
Table 4.4: Results of a Principal Components Analysis (PCA) on the response of six agroforestry tree species with respect to stem basal area increment, anatomical properties of the coarse root, stem and branch wood as well as hydraulic and leaf traits. Given are the loadings of the selected variables along the four main explanatory axes as well as the cumulative $r^{2}$ values (in brackets) for a given variable. Numbers below the four axes indicate the eigenvalues (EV) of the axes. Numbers in bold indicate the variables with the closest relation to the respective axis.

\begin{tabular}{|c|c|c|c|c|c|c|c|c|}
\hline \multirow[b]{2}{*}{ AGB } & \multicolumn{2}{|c|}{$\begin{array}{c}\text { Axis } 1 \\
\text { EV 0.46 }\end{array}$} & \multicolumn{2}{|c|}{$\begin{array}{c}\text { Axis } 2 \\
\text { EV 0.21 }\end{array}$} & \multicolumn{2}{|c|}{$\begin{array}{c}\text { Axis } 3 \\
\text { EV 0.16 }\end{array}$} & \multicolumn{2}{|c|}{$\begin{array}{c}\text { Axis } 4 \\
\text { EV } 0.12 \\
\end{array}$} \\
\hline & 0.31 & $(0.10)$ & -0.25 & $(0.16)$ & 0.87 & (0.93) & 0.06 & (0.93) \\
\hline DBH & 0.81 & $(0.65)$ & 0.08 & $(0.65)$ & 0.54 & (0.94) & 0.06 & (0.94) \\
\hline BAI & 0.17 & $(0.03)$ & -0.09 & $(0.04)$ & 0.83 & $(0.72)$ & 0.52 & (1.00) \\
\hline WD & -0.58 & $(0.34)$ & -0.05 & $(0.34)$ & 0.75 & (0.90) & -0.11 & (0.94) \\
\hline$A_{\text {lumen root }}$ & 0.90 & $(0.81)$ & -0.03 & $(0.81)$ & -0.03 & $(0.81)$ & -0.42 & (0.99) \\
\hline$A_{\text {lumen stem }}$ & -0.29 & $(0.08)$ & 0.79 & $(0.70)$ & 0.43 & (0.88) & -0.32 & (0.98) \\
\hline$A_{\text {lumen branch }}$ & -0.12 & $(0.01)$ & 0.93 & $(0.88)$ & -0.11 & $(0.90)$ & 0.21 & (0.94) \\
\hline$d_{\mathrm{h} \text { root }}$ & 0.92 & $(0.84)$ & 0.13 & $(0.86)$ & -0.11 & (0.87) & -0.36 & (1.00) \\
\hline$d_{\mathrm{h} \mathrm{stem}}$ & 0.91 & $(0.82)$ & 0.11 & $(0.83)$ & -0.17 & $(0.86)$ & 0.32 & (0.97) \\
\hline$d_{\mathrm{h} \text { branch }}$ & 0.82 & $(0.68)$ & -0.37 & $(0.81)$ & 0.04 & $(0.82)$ & 0.27 & (0.89) \\
\hline$K_{\mathrm{S}}^{\text {theo }}$ root & 0.88 & $(0.77)$ & 0.10 & $(0.78)$ & -0.26 & (0.84) & -0.39 & (1.00) \\
\hline$K_{\mathrm{S}}^{\text {theo }}$ stem & 0.88 & $(0.78)$ & 0.36 & $(0.91)$ & -0.05 & $(0.92)$ & 0.27 & (0.99) \\
\hline$K_{\mathrm{S}}^{\text {theo }}$ branch & 0.89 & $(0.79)$ & -0.09 & $(0.80)$ & 0.06 & $(0.80)$ & 0.39 & (0.95) \\
\hline$K_{\mathrm{S}}{ }^{\mathrm{emp}}$ root & 0.85 & $(0.72)$ & 0.18 & $(0.76)$ & -0.18 & (0.79) & -0.45 & (0.99) \\
\hline$K_{\mathrm{S}}{ }^{\mathrm{emp}}$ branch & -0.29 & $(0.08)$ & 0.66 & $(0.52)$ & 0.31 & $(0.62)$ & -0.40 & (0.78) \\
\hline$K_{\mathrm{L}}^{\mathrm{emp}}$ & -0.21 & $(0.04)$ & 0.87 & $(0.79)$ & 0.35 & $(0.92)$ & -0.27 & (0.99) \\
\hline$K_{\mathrm{L}}^{\text {theo }}$ & 0.78 & $(0.61)$ & 0.39 & $(0.76)$ & 0.26 & $(0.83)$ & 0.41 & (1.00) \\
\hline $\mathrm{HV}$ & 0.77 & $(0.59)$ & 0.64 & $(0.51)$ & -0.02 & $(0.70)$ & 0.05 & $(0.98)$ \\
\hline$N_{\text {leaf }}$ & -0.23 & $(0.05)$ & 0.68 & $(0.51)$ & -0.44 & $(0.70)$ & 0.53 & (0.98) \\
\hline$\delta^{13} C$ & 0.71 & $(0.50)$ & -0.41 & $(0.67)$ & 0.28 & (0.74) & -0.49 & (0.99) \\
\hline
\end{tabular}

The first axis was strongly positively associated with all wood anatomical traits (incl. HV and $\delta^{13} \mathrm{C}$ ), but negatively with WD. Axis 1 was furthermore positively related to DBH. Axis 2 was strongly associated with stem and branch lumen area as well as with the leaf traits $\left(K_{\mathrm{L}}{ }^{\mathrm{emp}}\right.$ and $N_{\text {leaf }}$ ). In contrast to $K_{\mathrm{S}}{ }^{\text {emp }}$ in root segments, branch $K_{\mathrm{S}}{ }^{\text {emp }}$ was associated with axis 2 and therefore showed an inter-relationship with $K_{\mathrm{L}}{ }^{\mathrm{emp}}$. BAI showed an only moderate association with the first axis and thus was only weakly correlated with the majority of wood anatomically and tree structural variables. BAI was correlated best with the third axis that was only associated with the variables AGB, DBH and WD (positively), as well as root $K_{\mathrm{S}}^{\text {theo }}$ and $K_{\mathrm{S}}{ }^{\mathrm{emp}}$ (negatively). A Pearson's coefficient of correlation analysis, however, revealed a strong relationship between BAI and $K_{\mathrm{S}}^{\text {theo }}$ on a species level for root, stem, and branch wood tissue (Figure 4.5 a-c). 

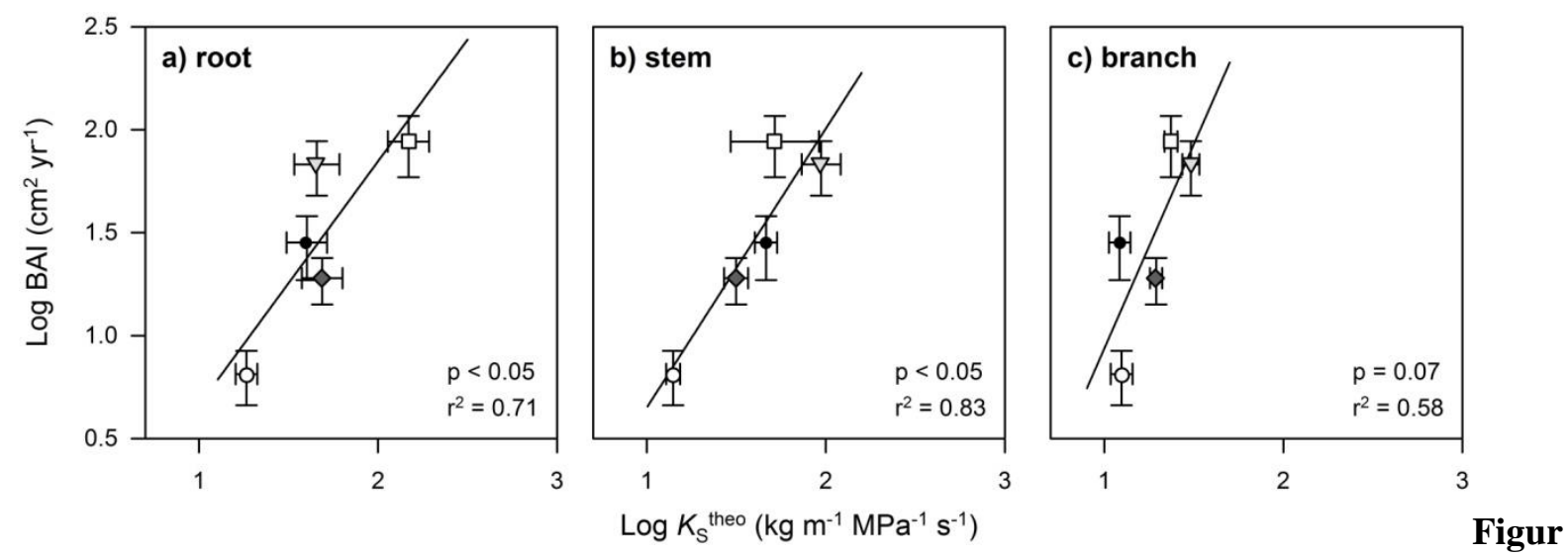

e 4.5: Relationship between stem basal area increment (BAI) of cacao and four shade tree species and theoretically calculated cross sectional sapwood area-specific hydraulic conductivity $\left(K_{\mathrm{S}}^{\text {theo }}\right)$ in the root (a), stem (b) and branch wood (c). Each symbol represents mean values for each tree species (c Th_ca; $\nabla$ Du_zi; $\diamond$ Gl_se; $\ulcorner$ Le_le; $\bullet$ Gn_gn). Error bars indicate \pm SE.

A systematic correlation analysis of pairs of traits confirmed that most of the interrelationships identified in the PCA on a species level were also valid on a tree individual level (Table 4.5). 


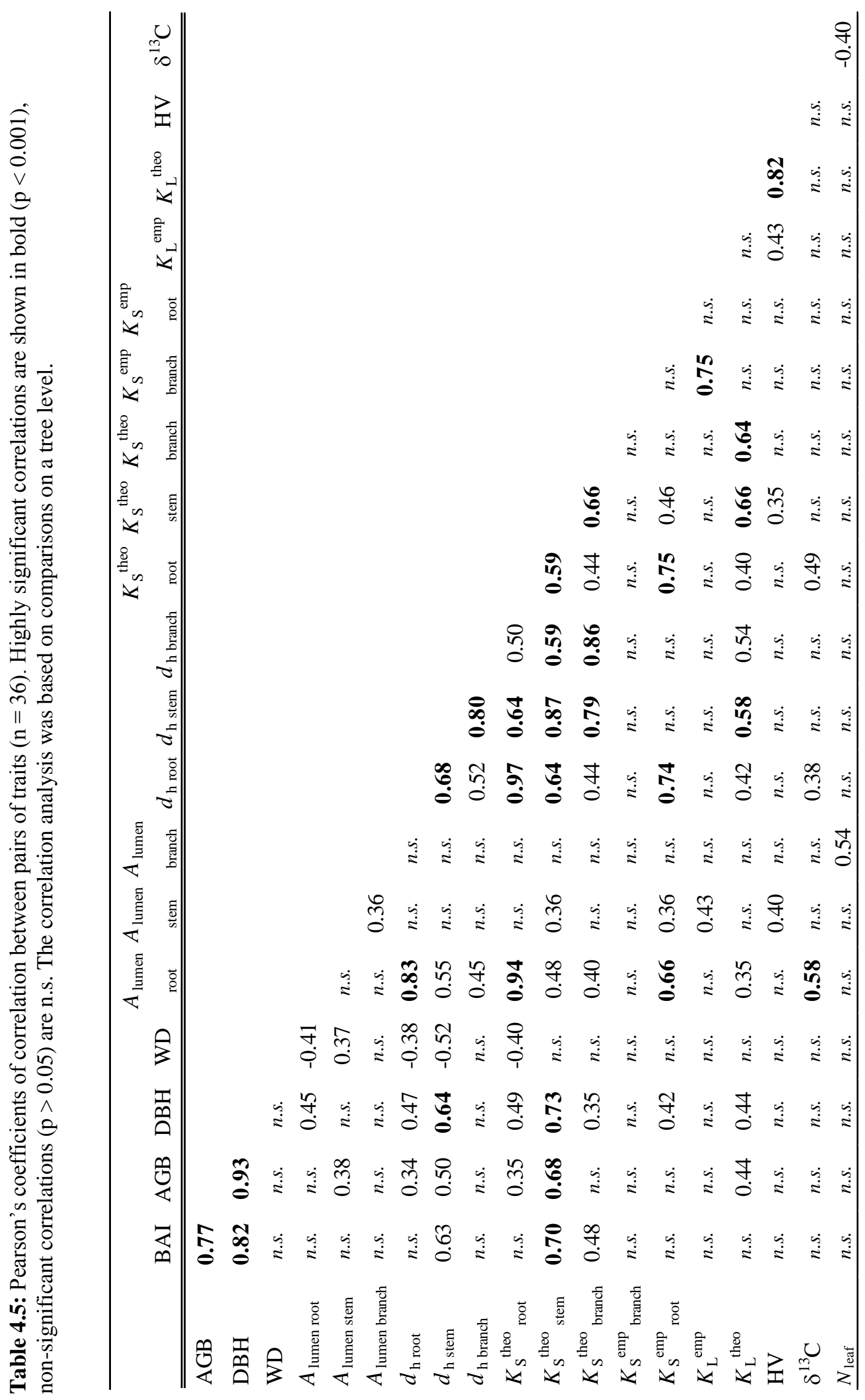


BAI was strongly interrelated with AGB as well as DBH and showed moreover a significant correlation with stem $d_{\mathrm{h}}$ and stem $K_{\mathrm{S}}{ }^{\text {theo }}$. None of these three variables were correlated with WD that generally showed only few and moreover relatively low correlations with other variables in the Pearson correlation analysis. Mixed effect models incorporating the pseudoreplication due to species confirmed that WD does not explain neither $K_{\mathrm{S}}{ }^{\text {theo }}, d_{\mathrm{h}}$ nor BAI in our data well ('lme'; $p>0.05$ ).

Contrary to significant relationships of stem wood $K_{\mathrm{S}}^{\text {theo }}$ with AGB, BAI and DBH, no relationship of $K_{\mathrm{S}}{ }^{\mathrm{emp}}$ between any of these traits could be found, except for $K_{\mathrm{S}}{ }^{\mathrm{emp}}$ in root segments that were related to $\mathrm{DBH}$.

As expected, all species and organs showed a positive relationship between $K_{\mathrm{S}}^{\text {theo }}$ and $d_{\mathrm{h}}$ (Table 4.5). Foliar nitrogen content $\left(N_{\text {leaf }}\right)$ as well as the carbon isotope signature $\left(\delta^{13} \mathrm{C}\right)$ did not show any relation with neither leaf area-specific hydraulic conductivity $\left(K_{\mathrm{L}}{ }^{\text {theo }}\right), K_{\mathrm{S}}{ }^{\mathrm{emp}}$ nor Huber value $(\mathrm{HV})$, but a strong significant correlation within each other. $N_{\text {leaf }}$ was unrelated to BAI among species $(\mathrm{p}>0.1, \mathrm{r}=0.05)$ also when excluding the three seasonal species. Stepwise model selection confirmed that $K_{\mathrm{S}}{ }^{\text {theo }}$ is the best predictor for AGB together with WD and neither $N_{\text {leaf }}, \delta^{13} \mathrm{C}$ nor $K_{\mathrm{S}}^{\mathrm{emp}}$ were explaining the variability in our data significantly.

\subsection{Discussion}

\section{Patterns in xylem anatomy among species in stem, root and branch wood}

Most studies on hydraulic anatomical properties in trees describe vessel sizes to be largest in roots and basipetally taper to the branches (Tyree and Zimmermann 2002, McElrone et al. 2004, Goncalves et al. 2007, Domec et al. 2009, Lintunen and Kalliokoski 2010). The first notification of this paradigm even goes back to observations by Nehemiah Grew in the $17^{\text {th }}$ century (Baas 1982). Generally, variation in conduit diameter is a compromise between hydraulic efficiency, safety and the maximization of conductivity per growth investment due to conduit tapering (Sperry et al. 2008, Sperry et al. 2012). As concluded by Tyree and Zimmermann (2002) the reason for conduit tapering is the control of water distribution, and more importantly to counter increases in flow resistance and gravimetrically forces with tree height to minimize the increasing risk of xylem dysfunction with path length (West et al. 1999, Anfodillo et al. 2006, Sperry et al. 2012). This is additionally mirrored in the meanwhile commonly observed relation between conduit size and vulnerability to cavitation (Wheeler et al. 2005, Maherali et al. 2006, Cai et al. 2010, Domec et al. 2010, Sterck et al. 2012). It is argued that in roots water stress will not be as great as in stems, since water potentials drop in going from root to stem to leaf (Tyree and Zimmermann, 2002). As long as soil water is still extractable, roots would then be less exposed to drought-induced embolism and might therefore afford larger vessels. Furthermore, with a small need of structural support and embedded in a soil matrix, biomechanical stress is unlikely to affect roots (McElrone et al. 2004, Pratt et al. 2007). Additionally, most plants have developed a mechanism to restore 
vessel functionality by refilling embolized vessels through living rays and paratracheal parenchyma. The contribution of paratracheal parenchyma was recently shown for grapevine by Brodersen et al. (2010), while the molecular and physiological paths were investigated by Chitarra et al. (2014). As coarse roots are located close to the water source it seems beneficial to restrict hydraulic failure to areas within the complex hydraulic network that are easily refilled. Embolism reversal is thought to occur by active transport of sugars into empty conduits, which are generally accumulated in high amounts within a trees rooting system (Würth et al. 2005).

Our results are in contrast to the common assumption as we found the largest vessels along the flow path in the stem xylem and not in the roots. Supporting our first hypothesis, our results are in accordance with the observations of a hump-shaped vessel size distribution along the flow path found in tropical trees of Indonesia (Schuldt et al. 2013), supported by findings from South America where the largest vessels were observed in the stem wood (Machado et al. 2007) or comparing just root and branch wood both organs showed similar vessel sizes (Fortunel et al. 2013). Our confirmative finding could be a response to permanent water availability and low evaporative demand in this humid region, where trees without severe drought limitation might have developed roots with large relative lumen area and less structural tissue that can achieve sufficiently high axial conductivities in these organs. Thereby they would compensate for the smaller vessel diameters in roots than in the trunk in accordance with the pipe model theory by Shinozaki et al. (1964). Originally, this theory attempted to explain plant architecture in a quantitative way by proposing that photosynthetic organs should be supported by an adequate structure of non-photosynthetic organs in order to guarantee functionality (Chiba 1998). Nevertheless, one has to keep in mind that the pipe model theory is not a hydraulic model, but should be viewed as a biomass allometry model with no particular implications concerning either hydraulics or biomechanics as proposed by McCulloh and Sperry (2005).

Machado et al. (2007) argued that shallow roots of moist tropical forest species, which is a common rooting pattern in tropical moist forests (Leuschner et al. 2006, Hertel et al. 2009), are subjected to variations in water availability and the narrower vessels in the root wood are a safety trade-off against cavitation. However, the vessel sizes found in coarse roots in the present study as well as in other tropical studies (Machado et al. 2007, Fortunel et al. 2013, Schuldt et al. 2013) are at least 30\% larger compared to e.g. temperate forest tree species (Köcher et al. 2012), and therefore might not directly be rated as an increased safety against cavitation compared to the stem or branch wood. It seems rational to assume that not the coarse root xylem, despite large vessel sizes, represents the most drought-sensitive organ, but rather that of fine roots with smaller diameter. In contrast to coarse roots, which are primarily responsible for axial water transport, fine roots represent the highest resistance for water transport within the rooting system due to radial water flow either along the apoplastic or cellular pathway (Steudle 2000). As the most distal organs they are scarified in response to drought in order to avoid serious harm to coarse and large roots like it has been observed in 
various temperate and boreal forests (Gaul et al. 2008, Chenlemuge et al. 2013, Hertel et al. 2013). Fine roots might thereby act as a sort of 'hydraulic fuse', which evolved from Zimmermann's segmentation hypothesis (Tyree and Zimmermann 2002) in analogy to the leaf petiole (Zufferey et al. 2011). At the root level this 'hydraulic segmentation' might additionally protect the below-ground system preventing the reverse water flow from main to lateral roots and back to the dryer soil as discussed for grapevine by Losivolo et al. (2008). Woody plants would accordingly restrict hydraulic failure to redundant organs that are readily replaced (Sperry et al. 2002) although it has been argued that the term 'hydraulic fuse' should be reconsidered since roots are not necessarily an 'expandable' organ (Gonzales-Benecke et al. 2010). The construction costs of fine roots and lignified small-diameter roots in term of carbon and nutrients may not be much smaller than for twigs and leaves, and the loss of roots is directly related to the loss of absorption capacity for nutrients and water. However, comparable data on fine root mortality and percentage loss of conductivity in coarse roots that would empirically support the idea that fine roots are sacrificed in order to protect the hydraulic system are to our knowledge not available so far.

Concurrently with decreasing vessel size, conduit frequency is generally reported to increase from the roots to the branches (e.g. Lintunen and Kalliokoski 2010). This commonly observed trade-off between vessel density and vessel diameter (Preston et al. 2006, Sperry et al. 2008, Zanne et al. 2010) could not be confirmed in our study where the stem wood showed by far the lowest vessel density compared to roots and branches. Since flow in capillary systems is proportional to the fourth power of vessel radius according to Hagen-Poiseuille law, variations in vessel diameter has a much greater effect on $K_{\mathrm{S}}^{\text {theo }}$ than variations in vessel density. However, due to the occurrence of a higher relative vessel lumen area and a few large vessels in roots we have observed that specific conductivity in the three seasonal species, i.e. G. sepium, E. subumbrans and L. leucocephala, was higher in roots than in stems, even though the largest vessels were observed in the stem wood. At least for E. subumbrans and L. leucocephala this pattern could additionally be explained by the highest relative vessel lumen area found in roots, i.e. less space was occupied by tracheids or fibers compared to the stem or branch wood. Furthermore, disproportionally high empirical conductance measured in E. subumbrans might be attributed to the presence of open-cut vessels, which are highly conductive as water does not have to pass pit membranes, which generally account for more than $50 \%$ of the total hydraulic resistance (Choat et al. 2008). However, since tree hydraulic traits have been associated with general habitat preferences of various species (Sperry 2000, Maherali et al. 2004), this finding could be due to the biogeographic background and could represent genetically determined adaptations to different water availability in the natural habitat of the species. While T. cacao, D. zibethinus and G. gnemon are known to be strictly wet tropical forest trees rather sensitive to drought and low air humidity (Brown 1997, Carr and Lockwood 2011), the other three species are reported to be fast-growing drought-resistant trees (Mrema et al. 1997, Fagbola et al. 2001). While drought resistance is recorded for some Erythrina species (da Silva et al. 2010, Manoharan et al. 2010), not many data are available 
on E. subumbrans, which is a species native to Indonesia. In a habitat where water stress is generally modest or absent such as the humid climate in Sulawesi, cavitation-avoiding mechanisms might be less beneficial than hydraulic efficiency and largest vessels can occur in stem xylem, thereby reducing the hydraulic resistance along the flow path. However, it remains speculative why the largest vessels along the flow path are observed in the root xylem only in biomes that frequently experience either drought- or frost stress. The size of a vessel is thought to be caused by the concentration of the plant hormone indole-3-acetic acid (IAA), an endogenous auxin, at the time of cell differentiation (Aloni 1987, Lovisolo et al. 2002), which is also related to the cambial age and related cambial activity as seen by the radial increase in vessel size at the stem base of a tree (Spicer and Gartner 2001). It would thus be of interest to extent the results of the present study to a quantification of IAA concentration in both coarse root and stem cambium in tropical and temperate trees; the latter should show higher concentrations in the root xylem independently of cambial age in agreement with the common paradigm that largest vessels are found in the rooting system.

\section{Relationships between vascular properties, tree stem growth and hydraulic conductivity}

Wood density (WD) is an easy to measure functional wood property that has been linked to various ecological and other functional traits. In species showing a relatively large fraction of vessels close to the hydraulically weighted mean vessel diameter $\left(d_{\mathrm{h}}\right), K_{\mathrm{S}}{ }^{\text {theo }}$ should correlate negatively with WD (Bucci et al. 2004, Meinzer et al. 2008, Gonzalez-Benecke et al. 2010). Similar to observations on tropical forest trees from perhumid tropical environments (Poorter et al. 2010, Schuldt et al. 2013) we expected WD to be unrelated to wood anatomical and hydraulic properties. Even though we found a correlation between WD and $d_{\mathrm{h}}$ on tree level, this relationship could not be confirmed accounting for species pseudoreplication in mixed effect models. Also we found no significant relationship of WD to basal stem area increment, contradicting former results on a close relation between WD and growth for tropical trees (King et al. 2006, Poorter et al. 2010, Hietz et al. 2013). Several other studies report WD to be partially decoupled from hydraulic conductivity due to variation of frequency and size of fibers in angiosperms (Preston et al. 2006, Martinez-Cabrera et al. 2009, Zanne et al. 2010). Results on the relationship between WD and vascular properties as well as tree growth are thus partly conflicting; while some studies confirm that WD varies inversely with vessel size (Preston et al. 2006, Jacobsen et al. 2007, Thomas et al. 2007, McCulloh et al. 2011, Gleason et al. 2012), others did not support this finding (Martinez-Cabrera et al. 2009, Poorter et al. 2010, Russo et al. 2010, Zanne et al. 2010, Fan et al. 2012). These contradicting results are indicating that the relation between $\mathrm{WD}$ and growth or vessel traits is not necessarily interrelated and should be viewed separately. We further suspect that the relation between wood properties and tree hydraulics may depend as well on biogeographical origin and drought-adaptation strategy of the species investigated since convergent environmental factors such as water availability are known to lead to adaptations in functional wood anatomical properties (Swenson and Enquist 2007, Gleason et al. 2013, Richardson et al. 2013). 
We found wood anatomical and derived hydraulic properties to be a much better predictor for tree stem growth performance than WD as $K_{\mathrm{S}}^{\text {theo }}$ of the all tree organs studied were strongly positively correlated with stem basal area increment on a species level. This is in accordance with a growing body of studies showing strong links between growth rate and wood anatomical traits (Zhang and Cao 2009, Poorter et al. 2010, Russo et al. 2010, Fan et al. 2012). In contrast, neither empirically measured branch and root $K_{\mathrm{S}}{ }^{\mathrm{emp}}$, nor foliar $\delta^{13} \mathrm{C}$ or foliar nitrogen content were good predictors for aboveground growth performance.

We expected to find close correlations between functional leaf traits assumed to be associated with high aboveground productivity, i.e. high foliar $\mathrm{N}$ content and more negative foliar $\delta^{13} \mathrm{C}$, and stem increment in our samples. However, no such correlation was found. This is most likely explained by the fact that our sampled species contained several $\mathrm{N}$-fixing legume species, our relatively low species number as well as due to the fact that our study was conducted in a perhumid region were drought stress is not to be expected.

\subsection{Conclusions}

Our study results suggest that even though vessel traits, growth performance and wood density relations follow distinct conceptually determined trade-offs, some of these longestablished paradigms might not be uniformly applicable to tree species from all biogeographic regions presumably due to their varying drought adaptation strategies. In moist tropical environments we could not confirm the paradigm of continuous conduit tapering from roots to branches although some traits (vessel density, relative vessel lumen area and theoretical sapwood area-specific conductivity) enabled a clear separation between the three strictly wet tropical species and the three seasonal tree species. We therefore expect patterns in vessel traits along the flow path from roots to branches to be dependent on the long-term precipitation regime at the biogeographic origin of the investigated tree species. Furthermore and contrary to common knowledge, the investigated tree species did neither show a relationship between above-ground growth performance and wood density nor foliar nitrogen content, nor between wood density and vessel size. Instead, we found growth rate to be closely linked with wood anatomical and derived hydraulic traits. Future research should thus include a systematic approach to different biogeographic regions and cover a wider range of ecosystem types particularly underrepresented biomes. 


\section{Acknowledgements}

This study was financed by the German Research Foundation (DFG) in the framework of the collaborative German - Indonesian research project CRC990 ('Ecological and Socioeconomic Functions of Tropical Lowland Rainforest Transformation Systems (Sumatra, Indonesia)', subproject B04 and ELUC ('Environmental and land-use change in Sulawesi, Indonesia'), subproject 'Shade trees in cacao agroforestry systems: influence on roots and net primary production'. We thank village heads and local plot owners for granting us access to and use of their properties as well as we are very thankful to our counterparts and local assistance for support of our study, and the three reviewers who provided helpful suggestions for improving the manuscript.

\section{Appendix}

Table A 4.1: Results from linear regression analyses between branch and root cross-sectional area $\left(A_{\text {cross }}, \mathrm{mm}^{2}\right)$ and corresponding xylem cross-sectional area $\left(A_{\text {xylem }}, \mathrm{mm}^{2}\right)$ without pith and bark for the eight tree species, and averaged across species for branches and roots. Given are sample number, intercept of the $\mathrm{x}$ - and $\mathrm{y}$-axis, slope, $\mathrm{p}$-value, coefficient of determination and the xylem to crosssectional area ratio $\left(A_{\text {xylem }} / A_{\text {cross }}\right.$, mean $\left.\pm \mathrm{SE}\right)$.

\begin{tabular}{lcccccccc}
\hline Species & Organ & $\mathbf{n}$ & \multicolumn{7}{c}{$\mathbf{A}_{\text {xylem }}=\mathbf{a}+\mathbf{b} \times \mathbf{A}_{\text {cross }}$} & & $\mathbf{A}_{\text {xylem }} / \mathbf{A}_{\text {cross }}$ \\
\hline \hline Th_ka & branch & 6 & 4.03 & -2.0914 & 0.5196 & $<0.001$ & 0.98 & $0.48 \pm 0.01$ \\
Er_su & branch & 6 & 12.61 & -7.4852 & 0.5936 & 0.021 & 0.68 & $0.45 \pm 0.04$ \\
Du_zi & branch & 6 & 27.53 & -18.8424 & 0.6844 & 0.001 & 0.94 & $0.49 \pm 0.02$ \\
Gl_se & branch & 6 & 7.42 & -4.7291 & 0.6375 & 0.002 & 0.92 & $0.56 \pm 0.04$ \\
Le_le & branch & 6 & -0.67 & 0.4622 & 0.6875 & $<0.001$ & 0.99 & $0.70 \pm 0.01$ \\
Gn_gn & branch & 6 & -2.54 & 1.6189 & 0.6378 & 0.001 & 0.96 & $0.66 \pm 0.01$ \\
All & branch & 36 & -0.91 & 0.5033 & 0.5507 & $<0.001$ & 0.76 & $0.56 \pm 0.02$ \\
& & & & & & & & \\
Th_ka & root & 6 & 0.14 & -0.0863 & 0.6161 & $<0.001$ & 0.99 & $0.61 \pm 0.01$ \\
Er_su & root & 8 & 5.82 & -2.6486 & 0.4547 & $<0.001$ & 0.89 & $0.40 \pm 0.02$ \\
Du_zi & root & 8 & 3.25 & -2.2785 & 0.7020 & $<0.001$ & 0.96 & $0.64 \pm 0.01$ \\
Gl_se & root & 5 & 23.40 & -13.1864 & 0.5636 & 0.016 & 0.72 & $0.42 \pm 0.05$ \\
Le_le & root & 6 & -13.21 & 4.6253 & 0.3501 & 0.006 & 0.84 & $0.43 \pm 0.02$ \\
Gn_gn & root & 6 & 519.48 & 58.8047 & -0.1132 & 0.225 & 0.15 & $0.25 \pm 0.05$ \\
All ${ }^{1)}$ & root & 33 & -0.84 & 0.4062 & 0.4830 & $<0.001$ & 0.68 & $0.51 \pm 0.02$ \\
\hline
\end{tabular}

\footnotetext{
${ }^{1)}$ Gn_Gn excluded from regression analysis.
} 


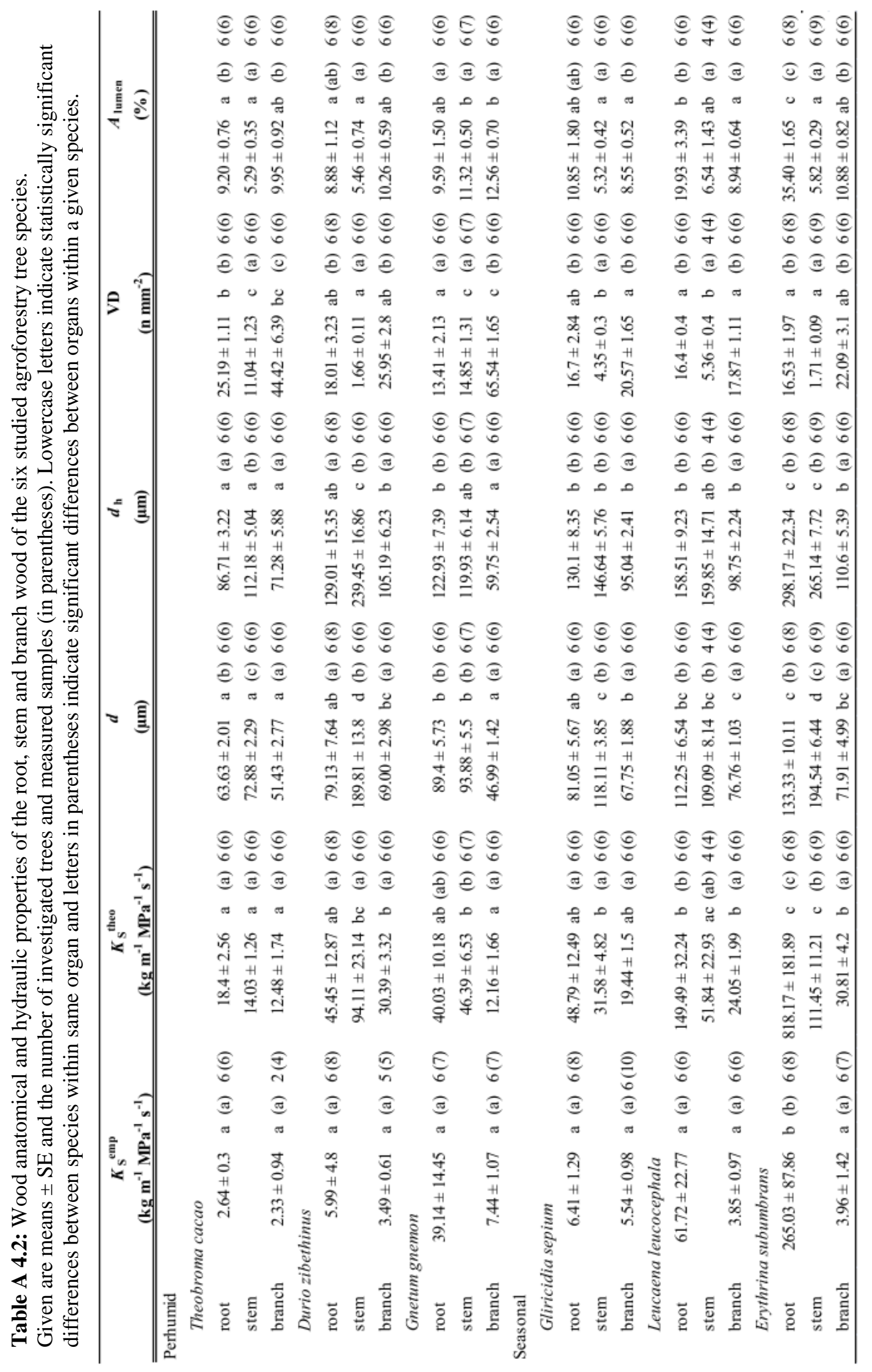




\section{References}

Achard, F., H. D. Eva, H.-J. Stibig, P. Mayaux, J. Gallego, T. Richards, and J.-P. Malingreau. 2002. Determination of deforestation rates of the world's humid tropical forests. Science 297:999-1002.

Aloni, R. 1987. Differentiation of Vascular Tissues. Annual Review of Plant Physiology and Plant Molecular Biology 38:179-204.

Anfodillo, T., V. Carraro, M. Carrer, C. Fior, and S. Rossi. 2006. Convergent tapering of xylem conduits in different woody species. New Phytologist 169:279-290.

Anfodillo, T., G. Petit, and A. Crivellaro. 2013. Axial conduit widening in woody species: A still neglected anatomical pattern. Iawa Journal 34:352-364.

Awad, H., T. Barigah, E. Badel, H. Cochard, and S. Herbette. 2010. Poplar vulnerability to xylem cavitation acclimates to drier soil conditions. Physiologia Plantarum 139:280288.

Baas, P. 1982. Systematic, phylogenetic and ecological wood anatomy - history and perspectives. Acta Botanica Neerlandica 31:501-501.

Brodersen, C. R., A. J. McElrone, B. Choat, M. A. Matthews, and K. A. Shackel. 2010. The dynamics of embolism repair in xylem: in vivo visualizations using high-resolution computed tomography. Plant Physiology 154:1088-95.

Brodribb, T. J., N. M. Holbrook, and M. V. Gutierrez. 2002. Hydraulic and photosynthetic co-ordination in seasonally dry tropical forest trees. Plant Cell and Environment 25:1435-1444.

Brown, S. 1997. Estimating Biomass and Biomass Change of Tropical Forests: a Primer. FAO Forestry Paper 134.

Bucci, S. J., G. Goldstein, F. C. Meinzer, F. G. Scholz, A. C. Franco, and M. Bustamante. 2004. Functional convergence in hydraulic architecture and water relations of tropical savanna trees: from leaf to whole plant. Tree Physiology 24:891-899.

Burnham, K. P., and D. R. Anderson. 2002. Model selection and multimodel inference: a practical information-theoretic approach. New York: Springer Science \& Business Media.

Cai, J., U. Hacke, S. Zhang, and M. T. Tyree. 2010. What happens when stems are embolized in a centrifuge? Testing the cavitron theory. Physiologia Plantarum 140:311-320.

Carlquist, S. 1994. Wood and bark anatomy of Gnetum gnemon L. Botanical Journal of the Linnean Society 116:203-221.

Carr, M. K. V., and G. Lockwood. 2011. The water relations and irrigation requirements of cocoa (Theobroma cacao L.): A review. Experimental Agriculture 47:653-676. 
Chave, J., C. Andalo, S. Brown, M. A. Cairns, J. Q. Chambers, D. Eamus, H. Folster, F. Fromard, N. Higuchi, T. Kira, J. P. Lescure, B. W. Nelson, H. Ogawa, H. Puig, B. Riera, and T. Yamakura. 2005. Tree allometry and improved estimation of carbon stocks and balance in tropical forests. Oecologia 145:87-99.

Chenlemuge, T., D. Hertel, C. Dulamsuren, M. Khishigjargal, C. Leuschner, and M. Hauck. 2013. Extremely low fine root biomass in Larix sibirica forests at the southern drought limit of the boreal forest. Flora 208:488-496.

Chiba, Y. 1998. Architectural analysis of relationship between biomass and basal area based on pipe model theory. Ecological Modelling 108:219-225.

Chitarra, W., R. Balestrini, M. Vitali, C. Pagliarani, I. Perrone, A. Schubert, and C. Lovisolo. 2014. Gene expression in vessel-associated cells upon xylem embolism repair in Vitis vinifera L. petioles. Planta 239:887-899.

Choat, B., A. R. Cobb, and S. Jansen. 2008. Structure and function of bordered pits: new discoveries and impacts on whole-plant hydraulic function. New Phytologist 177:608625.

Da Silva, E. C., M. F. A. Silva, R. J. M. C. Nogueira, and M.B. Albuquerque. 2010. Growth evaluation and water relations of Erythrina velutina seedlings in response to drought stress. Brazilian Journal of Plant Physiology 22:225-233.

Domec, J.-C., K. Schaefer, R. Oren, H. S. Kim, and H. R. Mccarthy. 2010. Variable conductivity and embolism in roots and branches of four contrasting tree species and their impacts on whole-plant hydraulic performance under future atmospheric $\mathrm{CO}_{2}$ concentration. Tree Physiology 30:1001-1015.

Domec, J.-C., J. M. Warren, F. C. Meinzer, and B. Lachenbruch. 2009. Safety factors for xylem failure by implosion and air-seeding within roots, trunks and branches of young and old conifer trees. Iawa Journal 30:101-120.

Enquist, B. J., G. B. West, E. L. Charnov, and J. H. Brown. 1999. Allometric scaling of production and life-history variation in vascular plants. Nature 401:907-911.

Espino, S., and H. J. Schenk. 2011. Mind the bubbles: achieving stable measurements of maximum hydraulic conductivity through woody plant samples. Journal of Experimental Botany 62:1119-1132.

Fagbola, O., O. Osonubi, K. Mulongoy, and S. A. Odunfa. 2001. Effects of drought stress and arbuscular mycorrhiza on the growth of Gliricidia sepium (Jacq). Walp, and Leucaena leucocephala (Lam.) de Wit. in simulated eroded soil conditions. Mycorrhiza 11:215223. 
Fan, Z.-X., S.-B. Zhang, G.-Y. Hao, J. W. F. Slik, and K.-F. Cao. 2012. Hydraulic conductivity traits predict growth rates and adult stature of 40 Asian tropical tree species better than wood density. Journal of Ecology 100:732-741.

FAO/JRC. 2012. Global forest land-use change 1990-2005, in: FAO Forestry Paper No. 169. (eds.) Erik J. Lindquist, Rémi D’annunzio, Adam Gerrand, Kenneth Macdicken, Frédéric Achard, René Beuchle, Andreas Brink, Hugh D. Eva, Philippe Mayaux and J. San-Miguel-Ayanz. Rome: Food and Agriculture Organization of the United Nations and European Commission Joint Research Centre.

Fisher, J. B., and F. W. Ewers. 1995. Vessel dimensions in liana and tree species of vessel dimensions Gnetum (Gnetales). American Journal of Botany 82:1350-1357.

Fortunel, C., J. Ruelle, J. Beauchêne, P. V. A. Fine, and C. Baraloto. 2013. Wood specific gravity and anatomy of branches and roots in 113 Amazonian rainforest tree species across environmental gradients. New Phytologist 202:79-94.

Gaul, D., D. Hertel, W. Borken, E. Matzner, and C. Leuschner. 2008. Effects of experimental drought on the fine root system of mature Norway spruce. Forest Ecology and Management 256:1151-1159.

Gleason, S. M., D. W. Butler, and P. Waryszak. 2013. Shifts in leaf and stem hydraulic traits across aridity gradients in Eastern Australia. International Journal of Plant Sciences 174:1292-1301.

Gleason, S. M., D. W. Butler, K. Zieminska, P. Waryszak, and M. Westoby. 2012. Stem xylem conductivity is key to plant water balance across Australian angiosperm species. Functional Ecology 26:343-352.

Goncalves, B., C. M. Correia, A. P. Silva, E. A. Bacelar, A. Santos, H. Ferreira, and J. M. Moutinho-Pereira. 2007. Variation in xylem structure and function in roots and stems of scion-rootstock combinations of sweet cherry tree (Prunus avium L.). TreesStructure and Function 21:121-130.

Gonzalez-Benecke, C. A., T. A. Martin, and G. F. Peter. 2010. Hydraulic architecture and tracheid allometry in mature Pinus palustris and Pinus elliottii trees. Tree Physiology 30:361-375.

Hajek, P., C. Leuschner, D. Hertel, S. Delzon, and B. Schuldt. 2014. Trade-offs between xylem hydraulic properties, wood anatomy and yield in Populus. Tree Physiology 34:744-756.

Hansen, M. C., S. V. Stehman, P. V. Potapov, T. R. Loveland, J. R. G. Townshend, R. S. Defries, K. W. Pittman, B. Arunarwati, F. Stolle, M. K. Steininger, M. Carroll, and C. Dimiceli. 2008. Humid tropical forest clearing from 2000 to 2005 quantified by using 
multitemporal and multiresolution remotely sensed data. Proceedings of the National Academy of Sciences of the United States of America 105:9439-9444.

Herberich, E., J. Sikorski, and T. Hothorn. 2010. A Robust Procedure for Comparing Multiple Means under Heteroscedasticity in Unbalanced Designs. Plos One 5:e9788.

Hertel, D., G. Moser, H. Culmsee, S. Erasmi, V. Horna, B. Schuldt, and C. Leuschner. 2009. Below- and above-ground biomass and net primary production in a paleotropical natural forest (Sulawesi, Indonesia) as compared to neotropical forests. Forest Ecology and Management 258:1904-1912.

Hertel, D., T. Strecker, H. Müller-Haubold, and C. Leuschner. 2013. Fine root biomass and dynamics in beech forests across a precipitation gradient - Is optimal resource partitioning theory applicable to water-limited mature trees? Journal of Ecology 101:1183-1200

Hietz, P., R. Valencia, J. S. Wright. 2013. Strong radial variation in wood density follows a uniform pattern in two neotropical rain forests. Functional Ecology 27:684-692.

Hoeber, S., C. Leuschner, L. Köhler, D. Arias-Aguilar, and B. Schuldt. 2014. The importance of hydraulic conductivity and wood density to growth performance in eight tree species from a tropical semi-dry climate. Forest Ecology and Management 330:126-136.

Jacobsen, A. L., F. W. Ewers, R. B. Pratt, W. A. Paddock, and S. D. Davis. 2005. Do xylem fibers affect vessel cavitation resistance? Plant Physiology 139:546-556.

Jacobsen, A. L., R. B. Pratt, F. W. Ewers, and S. D. Davis. 2007. Cavitation resistance among 26 chaparral species of southern California. Ecological Monographs 77:99-115.

King, D. A., S. J. Davies, M. N. N. Supardi, and S. Tan. 2005. Tree growth is related to light interception and wood density in two mixed dipterocarp forests of Malaysia. Functional Ecology 19:445-453.

King, D. A., S. J. Davies, S. Tan, and N. S. M. Noor. 2006. The role of wood density and stem support costs in the growth and mortality of tropical trees. Journal of Ecology 94:670-680.

Köcher, P., V. Horna, I. Beckmeyer, and C. Leuschner. 2012. Hydraulic properties and embolism in small-diameter roots of five temperate broad-leaved tree species with contrasting drought tolerance. Annals of Forest Science 69:693-703.

Leuschner, C., M. Wiens, M. Harteveld, D. Hertel, and S. Tjitrosemito. 2006. Patterns of fine root mass and distribution along a disturbance gradient in a tropical montane forest, Central Sulawesi (Indonesia). Plant and Soil 283:163-174.

Lintunen, A., and T. Kalliokoski. 2010. The effect of tree architecture on conduit diameter and frequency from small distal roots to branch tips in Betula pendula, Picea abies and Pinus sylvestris. Tree Physiology 30:1433-1447. 
Lovisolo, C., A. Schubert, and C. Sorce. 2002. Are xylem radial development and hydraulic conductivity in downwardly-growing grapevine shoots influenced by perturbed auxin metabolism? New Phytologist 156:65-74.

Lovisolo, C., I. Perrone, W. Hartung, and A. Schubert. 2008. An abscisic acid-related reduced transpiration promotes gradual embolism repair when grapevines are rehydrated after drought. New Phytologist 180:642-651.

Machado, S. R., R. A. Rodella, V. Angyalossy, and C. R. Marcati. 2007. Structural variations in root and stem wood of Styrax (Styracaceae) from Brazilian forest and cerrado. Iawa Journal 28:173-188.

Maherali, H., C. F. Moura, M. C. Caldeira, C. J. Willson, and R. B. Jackson. 2006. Functional coordination between leaf gas exchange and vulnerability to xylem cavitation in temperate forest trees. Plant Cell and Environment 29:571-583.

Maherali, H, Pockman WT, Jackson RB (2004). Adaptive variation in the vulnerability of woody plants to xylem cavitation. Ecology 85, 2184-2199.

Manoharan, P. T., V. Shanmugaiah, N. Balasubramanian, S. Gomathinayagam, M. P. Sharma,and K. Muthuchelian. 2010. Influence of AM fungi on the growth and physiological status of Erythrina variegata Linn. grown under different water stress conditions. European Journal of Soil Biology 46:151-156.

Martinez-Cabrera, H. I., C. S. Jones, S. Espino, and H. J. Schenk. 2009. Wood anatomy and wood density in shrubs: Responses to varying aridity along transcontinental transects. American Journal of Botany 96:1388-1398.

Martinez-Vilalta, J., E. Prat, I. Oliveras, and J. Pinol. 2002. Xylem hydraulic properties of roots and stems of nine Mediterranean woody species. Oecologia 133:19-29.

Mcculloh, K. A., F. C. Meinzer, J. S. Sperry, B. Lachenbruch, S. L. Voelker, D. R. Woodruff, and J.-C. Domec. 2011. Comparative hydraulic architecture of tropical tree species representing a range of successional stages and wood density. Oecologia 167:27-37.

Mcculloh, K. A., and J. S. Sperry. 2005. The evaluation of Murray's law in Psilotum nudum (Psilotaceae), an analogue of ancestral vascular plants. American Journal of Botany 92:985-989.

Mcculloh, K. A., J. S. Sperry, and F. R. Adler. 2003. Water transport in plants obeys Murray's law. Nature 421:939-942.

Mcculloh, K. A., J. S. Sperry, B. Lachenbruch, F. C. Meinzer, P. B. Reich, and S. L. Voelker. 2010. Moving water well: comparing hydraulic efficiency in twigs and trunks of coniferous, ring-porous, and diffuse-porous saplings from temperate and tropical forests. New Phytologist 186:439-450. 
Mcelrone, A. J., W. T. Pockman, J. Martinez-Vilalta, and R. B. Jackson. 2004. Variation in xylem structure and function in stems and roots of trees to $20 \mathrm{~m}$ depth. New Phytologist 163:507-517.

Meinzer, F. C., P. I. Campanello, J.-C. Domec, M. G. Gatti, G. Goldstein, R. VillalobosVega, and D. R. Woodruff. 2008. Constraints on physiological function associated with branch architecture and wood density in tropical forest trees. Tree Physiology 28: 1609-1617.

Meinzer, F. C., S. A. James, G. Goldstein, and D. Woodruff. 2003. Whole-tree water transport scales with sapwood capacitance in tropical forest canopy trees. Plant Cell and Environment 26:1147-1155.

Moser, G., C. Leuschner, D. Hertel, D. Hölscher, M. Köhler, D. Leitner, B. Michalzik, E. Prihastanti, S. Tjitrosemito, and L. Schwendenmann. 2010. Response of cocoa trees (Theobroma cacao) to a 13-month desiccation period in Sulawesi, Indonesia. Agroforestry Systems 79:171-187.

Motamayor, J. C., P. Lachenaud, J. Mota, R. Loor, D. N. Kuhn, J. S. Brown, and R. J. Schnell. 2008. Geographic and Genetic Population Differentiation of the Amazonian Chocolate Tree (Theobroma cacao L). Plos One 3:e3311.

Mrema, A. F., U. Granhall, and L. Sennerbyforsse. 1997. Plant growth, leaf water potential, nitrogenase activity and nodule anatomy in Leucaena leucocephala as affected by water stress and nitrogen availability. Trees-Structure and Function 12:42-48.

Poorter, L., I. Mcdonald, A. Alarcon, E. Fichtler, J.-C. Licona, M. Pena-Claros, F. Sterck, Z Villegas, and U. Sass-Klaassen. 2010. The importance of wood traits and hydraulic conductance for the performance and life history strategies of 42 rainforest tree species. New Phytologist 185:481-492.

Pratt, R. B., A. L. Jacobsen, F. W. Ewers, and S. D. Davis. 2007. Relationships among xylem transport, biomechanics and storage in stems and roots of nine Rhamnaceae species of the California chaparral. New Phytologist 174:787-798.

Preston, K. A., W. K. Cornwell, and J. L. Denoyer. 2006. Wood density and vessel traits as distinct correlates of ecological strategy in 51 California coast range angiosperms. New Phytologist 170:807-818.

R Development Core Team. 2014. R: A language and environment for statistical computing. R Foundation for Statistical Computing, Vienna, Austria. http://www.R-project.org.

Rice, R. A., and R. Greenberg. 2000. Cacao cultivation and the conservation of biological diversity. Ambio 29:167-173. 
Richardson, S. J., R. B. Allen, R. P. Buxton, T. A. Easdale, J. M. Hurst, C. W. Morse, R. D. Smissen, and D. A. Peltzer. 2013. Intraspecific Relationships among Wood Density, Leaf Structural Traits and Environment in Four Co-Occurring Species of Nothofagus in New Zealand. Plos One 8:e58878.

Russo, S. E., K. L. Jenkins, S. K. Wiser, M. Uriarte, R. P. Duncan, and D.A. Coomes. 2010. Interspecific relationships among growth, mortality and xylem traits of woody species from New Zealand. Functional Ecology 24:253-262.

Schroth, G., and C. A. Harvey. 2007. Biodiversity conservation in cocoa production landscapes: an overview. Biodiversity and Conservation 16:2237-2244.

Schuldt, B., C. Leuschner, N. Brock, and V. Horna. 2013. Changes in wood density, wood anatomy and hydraulic properties of the xylem along the root-to-shoot flow path in tropical rainforest trees. Tree Physiology 33:161-174.

Shinozaki, K., K. Yoda, K. Hozumi, and T. Kira. 1964. A quantitative analysis of plant formthe pipe model theory II. Further evidence of the theory and its application in forest ecology. Japanese Journal of Ecology 14:133-139.

Sperry, J. S. 2000. Hydraulic constraints on plant gas exchange. Agricultural and Forest Meteorology 104:13-23.

Sperry, J. S., K. L. Nichols, J. E. M. Sullivan, and S. E. Eastlack. 1994. Xylem embolism in ring-porous, diffuse-porous, and coniferous trees of northern Utah and interior Alaska. Ecology 75:1736-1752.

Sperry, J. S., J. R. Donnelly, and M. T. Tyree. 1988. A method for measuring hydraulic conductivity and embolism in xylem Plant Cell and Environment 11:35-40.

Sperry, J. S., U. G. Hacke, R. Oren, and J. P. Comstock. 2002. Water deficits and hydraulic limits to leaf water supply. Plant Cell and Environment 25:251-263.

Sperry, J. S., F. C. Meinzer, and K. A. Mcculloh. 2008. Safety and efficiency conflicts in hydraulic architecture: scaling from tissues to trees. Plant Cell and Environment 31:632-645.

Sperry, J. S., D. D. Smith, V. M. Savage, B. J. Enquist, K. A. Mcculloh, P. B. Reich, L. P. Bentley, and E. I. Von Allmen. 2012. A species-level model for metabolic scaling in trees I. Exploring boundaries to scaling space within and across species. Functional Ecology 26:1054-1065.

Spicer, R., and B. L. Gartner. 2001. The effects of cambial age and position within the stem on specific conductivity in Douglas-fir (Pseudotsuga menziesii) sapwood. TreesStructure and Function 15:222-229. 
Sterck, F. J., J. Martinez-Vilalta, M. Mencuccini, H. Cochard, P. Gerrits, R. Zweifel, A. Herrero, J. F. J. Korhonen, P. Llorens, E. Nikinmaa, A. Nole, R. Poyatos, F. Ripullone, and U. Sass-Klaassen. 2012. Understanding trait interactions and their impacts on growth in Scots pine branches across Europe. Functional Ecology 26:541549.

Steudle, E. 2000. Water uptake by roots: effects of water deficit. Journal of Experimental Botany 51:1531-1542.

Swenson, N. G., and B. J. Enquist. 2007. Ecological and evolutionary determinants of a key plant functional trait: Wood density and its community-wide variation across latitude and elevation. American Journal of Botany 94:451-459.

Thomas, D. S., K. D. Montagu, and J. P. Conroy. 2007. Temperature effects on wood anatomy, wood density, photosynthesis and biomass partitioning of Eucalyptus grandis seedlings. Tree Physiology 27:251-260.

Tscharntke, T., Y. Clough, S. A. Bhagwat, D. Buchori, H. Faust, D. Hertel, D. Hölscher, J. Juhrbandt, M. Kessler, I. Perfecto, C. Scherber, G. Schroth, E. Veldkamp, and T. C. Wanger. 2011. Multifunctional shade-tree management in tropical agroforestry landscapes - A review. Journal of Applied Ecology 48:619-629.

Tyree, M. T. 2003. Hydraulic limits on tree performance: transpiration, carbon gain and growth of trees. Trees-Structure and Function 17:95-100.

Tyree, M. T., and F. W. Ewers. 1991. The hydraulic architecture of trees and other woody plants. New Phytologist 119:345-360.

Tyree, M. T., and M. H. Zimmermann. 2002. Xylem structure and the ascent of sap. Berlin: Springer.

West, G. B., J. H. Brown, and B. J. Enquist. 1999. A general model for the structure and allometry of plant vascular systems. Nature 400:664-667.

Wheeler, J. K., J. S. Sperry, U. G. Hacke, and N. Hoang. 2005. Inter-vessel pitting and cavitation in woody Rosaceae and other vesselled plants: a basis for a safety versus efficiency trade-off in xylem transport. Plant Cell and Environment 28:800-812.

Würth, M. K. R., S. Peláez-Riedl, S. J. Wright, and C. Körner. 2005. Non-structural carbohydrate pools in a tropical forest. Oecologia 143:11-24.

Zanne, A. E., M. Westoby, D. S. Falster, D. D. Ackerly, S. R. Loarie, S. E. J. Arnold, and D. A. Coomes. 2010. Angiosperm wood structure: Global patterns in vessel anatomy and their relation to wood density and potential conductivity American Journal of Botany 97:207-215. 
Zhang, J.-L., and K.-F. Cao. 2009. Stem hydraulics mediates leaf water status, carbon gain, nutrient use efficiencies and plant growth rates across dipterocarp species. Functional Ecology 23:658-667.

Zufferey, V., H. Cochard, T. Ameglio, J.-L. Spring, and O. Viret. 2011. Diurnal cycles of embolism formation and repair in petioles of grapevine (Vitis vinifera $\mathrm{cv}$. Chasselas). Journal of experimental botany 62:3885-3894. 

CHAPTER 5

Synthesis 


\subsection{Synthesis}

At present, existing cacao cultivation systems are becoming increasingly intensified through removal of shade trees and greater inputs such as use of fertilizers and pesticides. In order to investigate the effects these intensifications induce, different cacao cultivation systems were investigated. Varying degrees of shade intensities and diversity were compared, focusing on above- and belowground biomass, carbon stocks, and net primary production and carbon sequestration (Chapter 2), as well as on vertical root distribution, fine root dynamics (Chapter 3 ) and hydraulic-anatomical architecture (Chapter 4) of cacao and shade trees. On the whole, this study set out to contribute to the development of strategies that allow more environmental-friendly and sustainable cacao cultivation that preserves high cacao yields, but also provides high carbon sequestration and maintain a high degree of biodiversity.

\subsection{Effects of shade trees on stand structure, biomass and carbon stocks}

The intensification of cacao cultivation systems through the removal of shade trees carries with it a massive loss of biodiversity and plant biomass and therefore carbon stocks (e.g. Rice and Greenberg 2000, Miettienen et al. 2011, Clough et al. 2011, Saatchi et al. 2011, Margono et al. 2012, Hansen et al. 2013). As hypothesized, total above- and belowground biomass and thus carbon stocks increased significantly from 23 to $124 \mathrm{Mg} \mathrm{ha}^{-1}$ and 11 to $57 \mathrm{Mg} \mathrm{C} \mathrm{ha}^{-1}$, respectively with an increasing shade tree cover from 50-93\% (Chapter 2). The Cacao-multi plots showed a 5fold increase in aboveground biomass and carbon stocks than measured in cacao monocultures. Biodiversity, as expressed by the Shannon index, decreased significantly with decreasing shade tree diversity and a significant positive interrelation between species richness and carbon stocks in above- and belowground biomass could be demonstrated (Chapter 2). Shade trees made the largest contribution to biomass and carbon stock, both above- and belowground, emphasizing the important role they play with respect to biodiversity, carbon storage, and carbon sequestration. In comparison to natural rainforest however, the total carbon pool calculated for the three different cacao cultivation systems investigated in this study made up only a minor proportion compared to that of original natural forest (e.g. Leuschner et al. 2013).

A major focus of the study was on effects of intensified management of cacao agroforests on the root system. Standing fine root biomass in the $300 \mathrm{~cm}$ deep profile was more than doubled along the diversity gradient from Cacao-mono to the Cacao-multi stands (206 to $432 \mathrm{~g}$ $\mathrm{m}^{-2}$, Chapter 3). This study revealed that there is indeed an effect of species composition on root biomass and vertical rooting patterns as vertical root segregation between cacao and shade tree roots in the Cacao-Gliricidia stands and a shift of cacao roots to deeper soil layers in the Cacao-multi plots (Chapter 3) were found. Cacao displayed a shallower root system with highest amounts of fine root biomass in the upper $20 \mathrm{~cm}$ in all cultivation systems, which might be due to the fact that especially $\mathrm{P}$ and $\mathrm{N}$ are predominantly accumulated in the uppermost soil layer as well as it could be advantageous to the extraction of the throughfall and 
stemflow that only reached the topsoil level (Schwendenmann et al. 2010). A similar pattern was found for cacao large and coarse roots (Chapter 3). In contrast to the vertical root segregation of the Cacao-Gliricidia sites, the presence of various shade trees altered the vertical root distribution of cacao causing a displacement of cacao roots at upper layers and a shift of fine root abundance to deeper soil layers. Cacao fine and coarse roots reached deeper soil depths when grown together with various shade trees, suggesting higher competition between cacao and shade trees leading cacao to exploit more soil volume in deeper soil layers, but this was not true for large roots. Shade trees in the Cacao-Gliricidia and the Cacao-multi sites concentrated most of their fine root biomass in the subsoil layers below $100 \mathrm{~cm}$.

In the present study, mean fine root diameter of cacao decreased with depth as well as with increasing shade tree abundance and diversity, whereas the average fine root diameter of shade trees increased with depth and diversity (Chapter 3). The specific surface length and area of cacao fine roots was greatest in $0-20 \mathrm{~cm}$ and in $20-100 \mathrm{~cm}$ soil depth, while it was lowest in the lower soil $(100-300 \mathrm{~cm})$ of the Cacao-multi stands. This might indeed compensate for the decrease in fine root biomass observed in this system and could result from intense root competition with the various co-occurring shade trees. Furthermore, cacao trees had the lowest specific root length and area in $0-20 \mathrm{~cm}$ soil depth in the Cacao-Gliricidia stands which might result from lower competition of cacao and Gliricidia due to their vertical root segregation.

The isotopic composition of plant water simultaneously extracted from stem wood tissue of cacao and shade trees further confirms a complementary soil water use in the case of the Cacao-Gliricidia cultivation system, with cacao trees obtaining water mainly between 40 and $60 \mathrm{~cm}$ soil depth, while Gliricidia primarily took up water from deeper soil depths (60-100 $\mathrm{cm})$ (Chapter 3). This complementarity may also have contributed to the enhanced water use in the Cacao-Gliricidia stand as described by Köhler et al. (2014), and probably also to the slightly higher productivity observed in this study (Chapter 3). The results from the Cacaomulti stand suggest that this result on cacao-shade tree interaction cannot be generalized. In the Cacao-multi system, we have a clear indication that cacao and shade trees use the same depth interval for soil water uptake, perhaps leading to the displacement of cacao roots to deeper soil depths.

\subsection{Effects of shade trees on productivity and carbon sequestration}

Similarly to tree biomass and corresponding carbon stocks, carbon sequestration rates were clearly highest in Cacao-multi plots with $18 \mathrm{Mg} \mathrm{ha}^{-1} \mathrm{yr}^{-1}$ compared to the less productive Cacao-Gliricidia and Cacao-mono stands with $13 \mathrm{Mg} \mathrm{ha}^{-1} \mathrm{yr}^{-1}$ and $9 \mathrm{Mg} \mathrm{ha}^{-1} \mathrm{yr}^{-1}$, respectively (Chapter 2). In agreement with the positive correlation of species richness and biomass, a significant correlation between species richness and annual carbon sequestration from net primary production could be proven. However, literature on carbon sequestration rates in agroforestry systems remains scarce. Despite carbon fixation being lower in diverse cacao agroforests than in primary forests, it is still greater than in perennial monocultures or annual 
crops (e.g. Rice and Greenberg 2000, Duguma et al. 2001, Schroth et al. 2002), once again emphasizing the benefit the presence and intensity of shade trees has in such cropping systems with regard to carbon sequestration and hence, mitigation of climate change and deforestation.

Higher wood and coarse root production of cacao trees growing under multiple shade tree species compared to cacao grown under Gliricidia or without shade trees was observed. These findings might be explained by the various beneficial ecosystem services that more diverse and complex cultivation systems provide, such as enhanced nutrient input and cycling, mitigation of drought stress by changing water use regime, and /or complementary resource use. Nevertheless, total NPP of cacao decreased with increasing shade intensity, although total NPP increased along with shade tree intensity (Chapter 2).

Nutrient input through nitrogen fixation by Gliricidia and other leguminous shade trees present on the shaded plots is likely to be an important source for nutrition of the CacaoGliricidia and the Cacao-multi systems. Further nutrient input and cycling is also provided by enhanced aboveground litter fall and decomposition. Several studies (e.g. Clough et al. 2011, Tscharntke et al. 2011) already reported evidence of physiological stress of shadeless cacao trees as it is naturally an understory tree species. The data on leaf litter collected in the present study, further confirm this statement, as leaf litter of cacao trees almost doubled in monocultures compared to the two shaded cultivation systems (Chapter 2), which seems to act as a stress response of cacao to drought and high solar radiation. It was shown for cacao that the highest net photosynthetic rates occurred already at photosynthetic photon flux densities until $400 \mu \mathrm{mol} \mathrm{m} \mathrm{m}^{-2}$ (Balashima et al. 1997, Baligar et al. 2008), equivalent to $25 \%$ of the intensity of full sunlight. In a recent study from Köhler et al. (2014), who investigated sap flux in the same sites, a trend for higher water use of cacao trees grown under shade was reported. Higher water use assumes enhanced vegetative growth, which supports our findings of enhanced stem wood and coarse root growth in shaded systems. Complementary resource use in agroforestry systems could also explain enhanced growth and high productivity of cacao under shade or might be an additional factor (Ong et al. 2004, Ewel and Mazzarino 2008, Moser et al. 2010, Schwendenmann et al. 2010).

Against our expectations, a reduction of yield according to increasing shade tree cover and diversity was not apparent. With cacao bean production rates of $2.0 \mathrm{Mg} \mathrm{ha}^{-1} \mathrm{yr}^{-1}$ in Cacaomulti stands, and $2.1 \mathrm{Mg} \mathrm{ha}^{-1} \mathrm{yr}^{-1}$ in Cacao-mono and Cacao-Gliricidia systems, respectively, no influence of shade tree presence on cacao bean yield could be detected (Chapter 2). Indeed, we found that based on cacao tree-individuals, cacao pod and bean production decreased to some extent with increasing shade tree abundance and diversity, although not significantly. However, the systematic increase in cacao tree number from monocultures to the Cacao-multi system fully compensated for this tree-individual decrease in fruit production. Considering the fact, that the observed change in cacao pod and bean production per tree was statistically not significant, it is likely that positive ecosystem services may have contributed to the consistent yields. Besides the other previously discussed ecosystem services, shade trees provide further 
positive ecosystem services like natural pest control through insectivorous bird species and insects (e.g. Klein et al. 2002, Clough et al. 2009, Bisseleua et al. 2009, Philpott et al. 2009, Wielgoss et al. 2012, Bisseleua et al. 2013), natural weed control and protection from wind dispersal of fungal diseases (Rice and Greenberg 2000) and a stable microclimate. Another important factor for an abundant fruit production is enhanced pollination services through higher biodiversity. This is very important for the strictly entomophilous cacao as pollinator abundance and intensity is positively correlated to pod set and thus yield (Young 1982, Groeneveld et al. 2010, Frimpong et al. 2011). Cacao monocultures may suffer reduced yields due to decreasing soil fertility and greater susceptibility to insect and disease infestation than shade grown cacao (Rice and Greenberg 2000, Belsky and Siebert 2003). Similarly, the greater susceptibility to droughts plays an important role in the functioning of cacao trees (Schwendenmann et al. 2010), as it is negatively correlated to cacao yield (Beer et al. 1998, Schwendenmann et al. 2010).

It was shown, that the removal of shade trees enhances cacao productivity only in the short-term (Johns 1999, Rice and Greenberg 2000, Belsky and Siebert 2003, SteffanDewenter et al. 2007, Clough et al. 2009) and increases instability of monocultural cacao cultivation systems, where yield tends to decrease after 15-20 years (Rice and Greenberg 2000). Moreover, shade trees increase the productive lifetime of cacao trees (Obiri et al. 2007, Clough et al. 2011) through the reduction of physical stress. Cacao age in the studied cultivation systems was already between 20-30 years (Chapter 2), which supports the assumption of a long-term productivity in case of shaded cacao agroforests.

In contrast to our expectations, no significant influence of shade tree abundance and diversity on total fine root productivity could be demonstrated. We found highest fine root production (for the whole $60 \mathrm{~cm}$ deep soil profile) of cacao fine roots in the monoculture decreasing with increasing shade tree diversity (Chapter 3). In general, shade trees produced proportionally less than cacao trees and we could not find any effect of soil depth on fine root production. Fine root turnover for cacao trees increased from monoculture to the multi-species shaded cultivation systems, indicating an increasing competition. Root lifespan decreased as fine root mortality (fine root necromass) increased with increasing shade tree diversity, meaning a higher $\mathrm{C}$ input to the soil (Guo et al. 2005, Hertel et al. 2009). Maximum turnover rates for cacao were found in the Cacao-multi systems. This might be due to the fact that high turnover rates result in a relatively large proportion of roots belonging to smaller size classes, which have a large surface area in relation to their volume and thus are efficient nutrient traps (Jordan and Escalante 1980).

As productivity of trees also depends on anatomical properties and the efficiency of the conduit network within trees (e.g. Jansen et al. 2011, Tyree and Ewers 1991), it is also important to look at wood anatomy and the hydraulic strategies of cacao and shade trees, which was not previously investigated in tropical agroforests. As hypothesized, we found wood anatomy and derived hydraulic properties positively related to aboveground growth performance (Chapter 4). In contrast, wood density, empirically measured branch and root 
hydraulic conductivity, foliar $\delta^{13} \mathrm{C}$ or foliar nitrogen content were only weakly correlated with the aboveground growth performance of cacao and co-occurring shade tree species. In contrast to most temperate tree species, a hump-shaped distribution of the vessels along the flow path from root to stem and twig xylem tissues was demonstrated. This might be due to the fact that the risk of cavitation is not that high in a perhumid environment (Schuldt et al. 2013), where normally permanent water supply is guaranteed. However, it should be pointed out that many shade tree species used in cacao agroforestry systems are not native to the cropping region. For example, Gliricidia sepium and Leucaena leucocephala are commonly used shade tree species originating from seasonally tropical dry forest areas in Central America. Not much is known so far on how drought adaptations are influenced by changes in environmental conditions in a different environment. This might gain importance in the light of global climate change, where monsoon rains are predicted to be delayed (Loo et al. 2004), and seasonality of rainfalls as well as locally occurring droughts are expected to increase (Feng et al. 2013, Cai et al. 2014). Differences between drought-adapted and perhumidadapted tree species were only present for some traits in our study, such as vessel density, relative vessel lumen area, and theoretical sapwood area-specific conductivity.

\subsection{Overall conclusions and resulting recommendation for cacao farmers}

The current study demonstrates that cacao bean yield does not necessarily have to decrease with increasing shade tree abundance and diversity. Lower fruit production per tree under shade can be compensated by a higher tree number and the positive ecosystem services provided by higher biodiversity. Moreover, farmers may profit from an additional income from the sale of timber, fruits, and fuel wood acquired from shade trees as well as from beneficial ecosystem services. In addition to the positive ecosystem effects, farmers can also achieve additional income from carbon payments (Somarriba et al. 2013), such as models supported by the REDD+ program (Reducing Emissions from Deforestation and Forest degradation) or other certification programs. The financial incentives as well as lower labor and input costs make cacao production relatively stable against highly fluctuating cacao prices and more attractive to farmers by compensating possible lower yields in the short-time compared to monocultures. Cacao monocultures may suffer reduced yields due to decreasing soil fertility and greater susceptibility to pests and diseases as well as a greater susceptibility to droughts than cacao grown under shade (Rice and Greenberg 2000, Belsky and Siebert 2002). Several studies have shown that moderate shade levels were reported to have only little effect on cacao and coffee yield (Baggio et al. 1997, Wood and Lass 2001, Perfecto et al. 2005, Clough et al. 2009, Tscharntke et al. 2011). Due to strong price fluctuations of cacao it might be more attractive for farmers to rely on stable production with possibly lower yield but also low costs, compared to higher short-term yield with high input and labor costs (e. g. Beer et al. 1998). 
This study also showed that vertical root segregation between crop and shade trees is possible if appropriate shade tree species are selected. This lowers competition for water and nutrients and cacao trees may additionally benefit from the nitrogen fixation of legume shade trees and the shade provided by them. Root biomass values increased with increasing shade tree diversity, which also enhances carbon storage and sequestration in the soil.

Overall, agroforests managed using a diverse shade canopy offer a great potential for longterm productivity, biodiversity conservation, and environmental protection compared to monocultural cropping systems (Rice and Greenberg 2000, De Beenhouwer et al. 2013). Therefore, agroforests can help decrease the rate of deforestation and the pressure on natural forests, which are the largest sink of terrestrial carbon (Jose and Bardhan 2012). The present study concludes that smallholder agroforests such as diverse cacao agroecosystems offer the opportunity to combine high yield, high biodiversity, and high carbon sequestration. 


\section{References}

Baggio, A., P. Caramori, A. Androcioli Filho, and L. Montoya. 1997. Productivity of southern Brazilian coffee plantations shaded by different stockings of Grevillea robusta. Agroforestry Systems 37:111-120.

Balasimha, D., E. Daniel, and P. Bhat. 1991. Influence of environmental factors on photosynthesis in cocoa trees. Agricultural and forest meteorology 55:15-21.

Baligar, V. C., J. A. Bunce, R. C. R. Machado, and M. K. Elson. 2008. Photosynthetic photon flux density, carbon dioxide concentration, and vapor pressure deficit effects on photosynthesis in cacao seedlings. Photosynthetica 46:216-221.

De Beenhouwer, M., R. Aerts, and O. Honnay. 2013. A global meta-analysis of the biodiversity and ecosystem service benefits of coffee and cacao agroforestry. Agriculture, Ecosystems \& Environment 175:1-7.

Beer, J., R. Muschler, D. Kass, and E. Somarriba. 1998. Shade management in coffee and cacao plantations. Agroforestry Systems 38:139-164.

Belsky, J., and S. Siebert. 2003. Cultivating cacao: Implications of sun-grown cacao on local food security and environmental sustainability. Agriculture and Human Values 20:277285.

Bisseleua, D., A. Missoup, and S. Vidal. 2009. Biodiversity conservation, ecosystem functioning, and economic incentives under cocoa agroforestry intensification. Conservation Biology 23:1176-1184.

Bisseleua, H., D. Fotio, Yede, A. Missoup, and S. Vidal. 2013. Shade tree diversity, cocoa pest damage, yield compensating inputs and farmers' net returns in West Africa. PloS one 8:e56115.

Cai, W., A. Santoso, G. Wang, E. Weller, L. Wu, K. Ashok, Y. Masumoto, and T. Yamagata. 2014. Increased frequency of extreme Indian Ocean Dipole events due to greenhouse warming. Nature 510:254-258.

Clough, Y., J. Barkmann, J. Juhrbandt, M. Kessler, T. C. Wanger, A. Anshary, D. Buchori, D. Cicuzza, K. Darras, D. D. Putra, S. Erasmi, R. Pitopang, C. Schmidt, C. H. Schulze, D. Seidel, I. Steffan-Dewenter, K. Stenchly, S. Vidal, M. Weist, A. C. Wielgoss, and T. Tscharntke. 2011. Combining high biodiversity with high yields in tropical agroforests. Proceedings of the National Academy of Sciences of the United States of America 108:8311-8316.

Clough, Y., H. Faust, and T. Tscharntke. 2009. Cacao boom and bust: sustainability of agroforests and opportunities for biodiversity conservation. Conservation Letters 2:197205. 
Duguma, B., J. Gockowski, and J. Bakala. 2001. Smallholder cacao (Theobroma cacao Linn.) cultivation in agroforestry systems of West and Central Africa: challenges and opportunities. Agroforestry systems 51:177-188.

Ewel, J., and M. Mazzarino. 2008. Competition from below for light and nutrients shifts productivity among tropical species. Proceedings of the National Academy of Sciences of the United States of America 105:18836-18841.

Feng, X., A. Porporato, and I. Rodriguez-Iturbe. 2013. Changes in rainfall seasonality in the tropics. Nature Climate Change 3:811-815.

Frimpong, E., B. Gemmill-Herren, I. Gordon, and P. K. Kwapong. 2011. Dynamics of insect pollinators as influenced by cocoa production systems in Ghana. Journal of Pollination Ecology 5:74-80.

Groeneveld, J. H., T. Tscharntke, G. Moser, and Y. Clough. 2010. Experimental evidence for stronger cacao yield limitation by pollination than by plant resources. Perspectives in Plant Ecology, Evolution and Systematics 12:183-191.

Guo, L. B., M. J. Halliday, S. J. M. Siakimotu, and R. M. Gifford. 2005. Fine root production and litter input: Its effects on soil carbon. Plant and Soil 272:1-10.

Hansen, M. C., P. V. Potapov, R. Moore, M. Hancher, S. A. Turubanova, A. Tyukavina, D. Thau, S. V. Stehman, S. J. Goetz, T. R. Loveland, A. Kommareddy, A. Egorov, L. Chini, C. O. Justice, and J. R. G. Townshend. 2013. High-resolution global maps of 21stcentury forest cover change. Science 342:850-853.

Hertel, D., M. Harteveld, and C. Leuschner. 2009. Conversion of a tropical forest into agroforest alters the fine root-related carbon flux to the soil. Soil Biology and Biochemistry 41:481-490.

Jansen, S., E. Gortan, F. Lens, M. A. Lo Gullo, S. Salleo, A. Scholz, A. Stein, P. Trifilò, and A. Nardini. 2011. Do quantitative vessel and pit characters account for ion-mediated changes in the hydraulic conductance of angiosperm xylem? New phytologist 189:218228.

Johns, N. D. 1999. Conservation in Brazil's chocolate forest: the unlikely persistence of the traditional cocoa agroecosystem. Environmental Management 23:31-47.

Jose, S., and S. Bardhan. 2012. Agroforestry for biomass production and carbon sequestration: an overview. Agroforestry Systems 86:105-111.

Klein, A.-M., I. Steffan-Dewenter, and T. Tscharntke. 2002. Predator-prey ratios on cocoa along a land-use gradient in Indonesia. Biodiversity and Conservation 11:683-693.

Köhler, M., A. Hanf, H. Barus, Hendrayanto, and D. Hölscher. 2014. Cacao trees under different shade tree shelter: effects on water use. Agroforestry systems 88:63-73. 
Leuschner, C., G. Moser, D. Hertel, S. Erasmi, D. Leitner, H. Culmsee, B. Schuldt, and L. Schwendenmann. 2013. Conversion of tropical moist forest into cacao agroforest: consequences for carbon pools and annual C sequestration. Agroforestry Systems $87: 1173-1187$.

Loo, Y. Y., L. Billa, and A. Singh. 2014. Effect of climate change on seasonal monsoon in Asia and its impact on the variability of monsoon rainfall in Southeast Asia. Geoscience Frontiers 6:1-7.

Margono, B. A., S. Turubanova, I. Zhuravleva, P. Potapov, A. Tyukavina, A. Baccini, S. Goetz, and M. C. Hansen. 2012. Mapping and monitoring deforestation and forest degradation in Sumatra (Indonesia) using Landsat time series data sets from 1990 to 2010. Environmental Research Letters 7:034010.

Miettinen, J., C. Shi, and S. C. Liew. 2011. Deforestation rates in insular Southeast Asia between 2000 and 2010. Global Change Biology 17:2261-2270.

Moser, G., C. Leuschner, D. Hertel, D. Hölscher, M. Köhler, D. Leitner, B. Michalzik, E. Prihastanti, S. Tjitrosemito, and L. Schwendenmann. 2010. Response of cocoa trees (Theobroma cacao) to a 13-month desiccation period in Sulawesi, Indonesia. Agroforestry Systems 79:171-187.

Obiri, B. D., G. A. Bright, M. A. McDonald, L. C. N. Anglaaere, and J. Cobbina. 2007. Financial analysis of shaded cocoa in Ghana. Agroforestry Systems 71:139-149.

Ong, C. K., R. M. Kho, and S. Radersma. 2004. Ecological interactions in multispecies agroecosystems: concepts and rules. CABI Publishing, Wallingford.

Perfecto, I., J. Vandermeer, A. Mas, and L. Soto-Pinto. 2005. Biodiversity, yield, and shade coffee certification. Ecological Economics 54:435-446.

Philpott, S. M., O. Soong, J. H. Lowenstein, A. Pulido Luz, D. Lopez Tobar, D. F. B. Flynn, and F. DeClerck. 2009. Functional richness and ecosystem services : bird predation on arthropods in tropical agroecosystems. Ecological Applications 19:1858-1867.

Rice, R. A., and R. Greenberg. 2000. Cacao Cultivation and the Conservation of Biological Diversity. Ambio: A Journal of the Human Environment 29:167-173.

Saatchi, S. S., N. L. Harris, S. Brown, M. Lefsky, E. T. A. Mitchard, W. Salas, B. R. Zutta, W. Buermann, S. L. Lewis, S. Hagen, S. Petrova, L. White, M. Silman, and A. Morel. 2011. Benchmark map of forest carbon stocks in tropical regions across three continents. Proceedings of the National Academy of Sciences of the United States of America 108:9899-904. 
Schroth, G., S. A. D’Angelo, W. G. Teixeira, D. Haag, and R. Lieberei. 2002. Conversion of secondary forest into agroforestry and monoculture plantations in Amazonia: consequences for biomass, litter and soil carbon stocks after 7 years. Forest Ecology and Management 163:131-150.

Schuldt, B., C. Leuschner, N. Brock, and V. Horna. 2013. Changes in wood density, wood anatomy and hydraulic properties of the xylem along the root-to-shoot flow path in tropical rainforest trees. Tree Physiology 33:161-174.

Schwendenmann, L., E. Veldkamp, G. Moser, D. Hölscher, M. Köhler, Y. Clough, I. Anas, G. Djajakirana, S. Erasmi, D. Hertel, D. Leitner, C. Leuschner, B. Michalzik, P. Propastin, A. Tjoa, T. Tscharntke, and O. van Straaten. 2010. Effects of an experimental drought on the functioning of a cacao agroforestry system, Sulawesi, Indonesia. Global Change Biology 16:1515-1530.

Somarriba, E., R. Cerda, L. Orozco, M. Cifuentes, H. Dávila, T. Espin, H. Mavisoy, G. Ávila, E. Alvarado, V. Poveda, C. Astorga, E. Say, and O. Deheuvels. 2013. Carbon stocks and cocoa yields in agroforestry systems of Central America. Agriculture, Ecosystems \& Environment 173:46-57.

Steffan-Dewenter, I., M. Kessler, J. Barkmann, M. M. Bos, D. Buchori, S. Erasmi, H. Faust, G. Gerold, K. Glenk, S. R. Gradstein, E. Guhardja, M. Harteveld, D. Hertel, P. Höhn, M. Kappas, S. Köhler, C. Leuschner, M. Maertens, R. Marggraf, S. Migge-Kleian, J. Mogea, R. Pitopang, M. Schaefer, S. Schwarze, S. G. Sporn, A. Steingrebe, S. S. Tjitrosoedirdjo, S. Tjitrosemito, A. Twele, R. Weber, L. Woltmann, M. Zeller, and T. Tscharntke. 2007. Tradeoffs between income, biodiversity, and ecosystem functioning during tropical rainforest conversion and agroforestry intensification. Proceedings of the National Academy of Sciences of the United States of America 104:4973-4978.

Tscharntke, T., Y. Clough, S. A. Bhagwat, D. Buchori, H. Faust, D. Hertel, D. Hölscher, J. Juhrbandt, M. Kessler, I. Perfecto, C. Scherber, G. Schroth, E. Veldkamp, and T. C. Wanger. 2011. Multifunctional shade-tree management in tropical agroforestry landscapes - A review. Journal of Applied Ecology 48:619-629.

Tyree, M. T., and F. W. Ewers. 1991. The hydraulic architecture of trees and other woody plants. New Phytologist 119:345-360.

Wielgoss, A., Y. Clough, B. Fiala, A. Rumede, and T. Tscharntke. 2012. A minor pest reduces yield losses by a major pest: Plant-mediated herbivore interactions in Indonesian cacao. Journal of Applied Ecology 49:465-473.

Wood, G. A. R., and R. A. Lass. 2001. Cocoa. 4th ed. Blackwell Science.

Young, A. M. 1982. Effects of Shade Cover and Availability of Midge Breeding Sites on Pollinating Midge Populations and Fruit Set in Two Cocoa Farms. Journal of Applied Ecology 19:47-63. 
CHAPTER 5 


\section{Index of Tables}

Table 1.1: Locational and soil characteristics of the nine study sites grouped into the three cultivation systems investigated in the Kulawi valley as well as plantation management practices during the study period (2011-2013).

Table 2.1: Location, climatic and soil characteristics of the nine study sites grouped into the three cultivation systems investigated in the Kulawi valley. Cacao-mono: cacao in monoculture, Cacao-Gliricidia: cacao growing under Gliricidia sepium, Cacao-multi: cacao agroforests with multi-species shade layer. The soil parameters are given as means $\pm \mathrm{SE}$ and refer to the topsoil $\left(0-10 \mathrm{~cm}\right.$ soil depth) except for the soil carbon stock $\mathrm{C}_{\text {pool }}$ which refers to the whole sample profile $(0-60 \mathrm{~cm}$ soil depth).

Table 2.2: Aboveground stand structural properties of the three cultivation systems in the Kulawi valley (means \pm SE of each three stands). Different capital letters indicate statistically significant differences between the agroforestry systems ('all'), lower case letters significant differences of the different agroforest components (cacao or shade trees, or both) between the cultivation systems, and lower case Greek letters significant differences between cacao and shade trees within a cultivation system $(\mathrm{P}<0.05) \ldots \ldots \ldots . . .44$

Table 2.3: Above- and belowground carbon stocks and the shoot:root carbon ratio (means \pm SE). Only for the tree group 'all' fine root data is included. Given are means and standard errors. Different capital letters indicate statistically significant differences between the agroforestry systems, lower case letters indicate statistically significant differences of the different tree groups between the cultivation systems and lower case Greek letter indicate statistically significant differences between cacao and shade trees within a cultivation system $(P<0.05)$

Table 2.4: Components of annual net primary production (NPP) and the associated carbon pools (in $\mathrm{Mg} \mathrm{ha}^{-1} \mathrm{yr}^{-1}$ or $\mathrm{Mg} \mathrm{C} \mathrm{ha}^{-1} \mathrm{yr}^{-1}$ ) in the three cacao cultivation systems (means $\pm \mathrm{SE}$ ). Note that coarse root biomass production includes production of root stocks as well. Different capital letters indicate statistically significant differences of all tree groups in the whole soil profile between the agroforestry systems, lower case letters significant differences of the different tree groups between the cultivation systems and lower case Greek letter significant differences between cacao and shade trees within a cultivation system $(P<$ $0.05)$.

Table 2.5: Results of a PCA analysis based on the plots of the three studied cacao cultivation systems and their corresponding data on cacao bean yield, carbon stores, stand structural data and diversity. Given are the eigenvalues (EV) of the four main axes and the loading of nine parameters on these. The values in brackets give the fraction of variance explained by the variable. The most important factors on each axis are printed bold. . .50

Table 2.6: Pearson correlation coefficients of linear regressions between species diversity (Shannon Index) and yield and above- and belowground carbon stocks from biomass and net primary production (NPP).

Table A 2.1: Aboveground stand structural properties of the nine study sites of the three cultivation systems in the Kulawi valley (means per plot).

Table A 2.2: Above- and belowground biomass stocks and the shoot : root ratio of the nine study sites of the three cultivation systems in the Kulawi valley (means per plot). Only for the group 'all' fine root data is included.

Table A 2.3: Above- and belowground carbon stocks and the shoot : root carbon ratio of the nine study sites of the three cultivation systems in the Kulawi valley (means per plot). Only for the group 'all' fine root data is included.

Table A 2.4: Components of annual net primary production (NPP) (in $\mathrm{Mg} \mathrm{ha}^{-1} \mathrm{yr}^{-1}$ ) of the nine study sites of the three cultivation systems in the Kulawi valley (means per plot). Note that coarse root biomass production includes production of root stocks as well.

Table A 2.5: Associated carbon pools (in $\mathrm{Mg} \mathrm{C} \mathrm{ha}^{-1} \mathrm{yr}^{-1}$ ) in annual net primary production (NPP) of the nine study sites of the three cultivation systems in the Kulawi valley (means per 
plot). Note that coarse root biomass production includes production of root stocks as well.

Table 3.1: Ratio of fine root biomass (FRB) to fine root necromass (FRN) in the different cacao cultivation systems in the Kulawi valley (Sulawesi, Indonesia) from 0-60 cm depth, shown in 3 soil depths $(0-20 \mathrm{~cm}, 20-40 \mathrm{~cm}, 40-60 \mathrm{~cm}$, and the total profile $(0-60 \mathrm{~cm})$. Capital letters indicate statistically significant differences between the agroforestry systems; lower case letters indicate statistically significant differences of the different soil depths between the cultivation systems $(p<0.05)$.

Table 3.2: Biomass of fine roots $(\mathrm{d}<2 \mathrm{~mm})$, large roots $(\mathrm{d}=2-5 \mathrm{~mm})$ and coarse roots $(\mathrm{d}>5$ $\mathrm{mm}$ ) of cacao trees and shade trees in the different soil depths of the three cacao agroforestry systems in the Kulawi valley (Sulawesi, Indonesia). The percentage proportion of the profile's total in a given soil depth is given in brackets. Different capital letters indicate statistically significant differences between the agroforestry systems; lower case Latin letters indicate statistically significant differences of the different soil depths between the cultivation systems and lower case Greek letters indicate statistically significant differences between cacao and shade trees within a cultivation system $(\mathrm{p}<0.05)$

Table 3.3: Cumulative vertical biomass distribution of fine and large roots down to $300 \mathrm{~cm}$ soil depth of Theobroma cacao, Gliricidia sepium and five other representative shade tree species in the three different cacao cultivation systems in the Kulawi valley (Sulawesi, Indonesia). The steepness of the root biomass decrease with soil depth is expressed by the $\beta$ value of the regression equation $\mathrm{y}=1-\beta^{d}$, (see Gale and Grigal 1987) with y being the cumulative root biomass fraction in $\mathrm{g} \mathrm{m}^{-2}$ and $d$ being the soil depth in $\mathrm{cm}$. Low $\beta$ values indicate a steep decrease in root biomass with soil depth whereas high values indicate relatively large proportion of the root biomass in a deeper soil depth. Given are furthermore $r$ and $\mathrm{P}$ values obtained for the respective regression model.

Table 3.4: Mean and absolute maximum rooting depth of fine roots (diameter $<2 \mathrm{~mm}$ ), large roots (diameter $2-5 \mathrm{~mm}$ ), and coarse roots (diameter $>5 \mathrm{~mm}$ ) of cacao and six shade tree species in $300 \mathrm{~cm}$ deep soil profiles of the three cacao cultivation systems in the Kulawi valley (Sulawesi, Indonesia). Given are means and standard errors. Different capital letters indicate statistically significant differences between the agroforestry systems; lower case Latin letters indicate statistically significant differences of the different tree groups between the cultivation systems and lower case Greek letters indicate statistically significant differences between cacao and shade trees within a cultivation system $(p<0.05)$.

Table 3.5: Fine root turnover in the soil profile of $0-60 \mathrm{~cm}$ depth of cacao and shade trees of the three cacao cultivation systems in the Kulawi valley (Sulawesi, Indonesia). Given are means and standard errors. Capital letters indicate statistically significant differences of all tree groups in the whole soil profile between the agroforestry systems; lower case Latin letters indicate statistically significant differences of the different tree groups between the cultivation systems and lower case Greek letters indicate statistically significant differences between cacao and shade trees within a cultivation system $(\mathrm{p}<0.05)$.

Table 3.6: Fine root morphological traits of cacao and shade trees in the $300 \mathrm{~cm}$ deep soil profiles in the three different cultivation systems in the Kulawi valley (Sulawesi, Indonesia). Shown are fine root diameter, specific root length (SRL) and specific root area (SRA). Given are means and standard errors. Lower case Latin letters indicate statistically significant differences of the different tree groups between the cultivation systems and lower case Greek letters indicate statistically 
significant differences between cacao and shade trees within a cultivation system $(\mathrm{p}<0.05)$

Table 3.7: Results of a Principal components analysis (PCA) based on the plots of the three studied cacao cultivation systems in the Kulawi valley (Sulawesi, Indonesia) and their corresponding data on above- and belowground net primary production, biomass, stand structural data and diversity. Given are the eigenvalues (EV) of the four main axes and the loading of sixteen parameters on these. The values in brackets give the cumulative fraction of variance explained by the variable. The most important factors on each axis are printed bold.

Table 3.8: Pearson correlation coefficients of linear regressions between the parameters fine root biomass $(0-300 \mathrm{~cm}$ soil depth), fine root biomass $(0-60 \mathrm{~cm}$ soil depth), and fine root production (0-60 $\mathrm{cm}$ soil depth) and data of above- and belowground net primary production, above- and belowground biomass and stand structural data $(*$ $\mathrm{p}<0.1$; ** $\mathrm{p}<0.05$; *** $\mathrm{p}<0.001$ ). Please note that the source 'belowground NPP' is different from the variable 'fine root production' as it was obtained from allometric equation models and contains production of large and coarse roots as well as the root stump.

Table A3.1: Soil characteristics of the three cacao cultivation systems investigated in the Kulawi valley (Sulawesi, Indonesia). Given is the range of the means of the single study sites from soil samples taken in four different soil depths $(0-10 \mathrm{~cm}, 10-20 \mathrm{~cm}, 20-40 \mathrm{~cm}$ and $40-60 \mathrm{~cm}$ ). The carbon pools are given as means \pm SE. Lower case Latin letters indicate statistically significant differences of the different soil depths between the cultivation systems and lower case Greek letters indicate statistically significant differences between cacao and shade trees within a cultivation system $(\mathrm{p}<0.05)$.

Table A3.2: Stand structural variables of the three cultivation systems investigated in the Kulawi valley (Sulawesi, Indonesia). Given are means \pm SE. Cacao-mono: Cacao in monoculture, Cacao-Gliricidia: Cacao growing under Gliricidia sepium shade tree cover, Cacao-multi: Cacao agroforests with multi-species shade tree cover. Different capital letters indicate statistically significant differences between the agroforestry systems; lower case Latin letters indicate statistically significant differences of the different tree groups between the Cultivation systems and lower case Greek letters indicate statistically significant differences between cacao and shade trees within a Cultivation system $(p<0.05)$ (see Abou Rajab et al. (in revision)).

Table A3.3: Necromass of fine roots $(\mathrm{d}<2 \mathrm{~mm})$ of cacao trees and shade trees in the different soil depths of the three cacao agroforestry systems in the Kulawi valley (Sulawesi, Indonesia). The percentage proportion of the profile's total in a given soil depth is given in brackets. Different capital letters indicate statistically significant differences between the agroforestry systems; lower case Latin letters indicate statistically significant differences of the different soil depths between the cultivation systems and lower case Greek letters indicate statistically significant differences between cacao and shade trees within a cultivation system $(\mathrm{p}<0.05)$

Table A3.4: Fine root morphology on a species level of shade tree species in the Cacao-multi cultivation systems in the Kulawi valley (Sulawesi, Indonesia). Shown are mean fine root diameter, specific root length (SRL) and specific root area (SRA). Given are means and standard errors.

Table 4.1: List of major variables with definition and units employed.

Table 4.2:Tree height $(\mathrm{H})$, diameter at breast height (DBH), wood density (WD), aboveground biomass (AGB) and basal area increment (BAI) of the six tree species in cocoa agroforests. Shown values are means \pm SE and the number of investigated tree individuals. * For BAI, however, only three tree individuals of Gnetum gnemon, two of Leucaena leucocephala, and one of Erythrina subumbrans were available (see Material and Methods section). 
Table 4.3:Leaf morphological, hydraulic, and chemical properties of the six investigated tree species. Values are means $\pm \mathrm{SE}$; the number of investigated trees and measured samples (in parentheses) is also given. Different small letters indicate differences between species. See Table 4.1 for definition of abbreviations.

Table 4.4: Results of a Principal Components Analysis (PCA) on the response of six agroforestry tree species with respect to stem basal area increment, anatomical properties of the coarse root, stem and branch wood as well as hydraulic and leaf traits. Given are the loadings of the selected variables along the four main explanatory axes as well as the cumulative $\mathrm{r}^{2}$ values (in brackets) for a given variable. Numbers below the four axes indicate the eigenvalues (EV) of the axes. Numbers in bold indicate the variables with the closest relation to the respective axis

Table 4.5: Pearson's coefficients of correlation between pairs of traits $(n=36)$. Highly significant correlations are shown in bold $(\mathrm{p}<0.001)$, non-significant correlations $(\mathrm{p}>0.05)$ are n.s. The correlation analysis was based on comparisons on a tree level.

Table A 4.1: Results from linear regression analyses between branch and root cross-sectional area $\left(A_{\text {cross }}, \mathrm{mm}^{2}\right)$ and corresponding xylem cross-sectional area $\left(A_{\text {xylem }}, \mathrm{mm}^{2}\right)$ without pith and bark for the eight tree species, and averaged across species for branches and roots. Given are sample number, intercept of the $\mathrm{x}$ - and $\mathrm{y}$-axis, slope, $\mathrm{p}$-value, coefficient of determination and the xylem to cross-sectional area ratio $\left(A_{\text {xylem }} / A_{\text {cross }}\right.$, mean $\left.\pm \mathrm{SE}\right) . .131$

Table A 4.2: Wood anatomical and hydraulic properties of the root, stem and branch wood of the six studied agroforestry tree species. 


\section{Index of Figures}

Figure 1.1: Forest cover loss in Indonesia from 2000-2014

Figure 1.2: Forest cover loss in Sulawesi, Indonesia. A) Total forest loss from 2001-2014 in Sulawesi. B) Forest loss per year from 2001-2014 in the study region around the Lore Lindu National Park (white line).

Figure 1.3: Map of the study region with the Lore Lindu National Park (green) and the Kulawi valley (red rectangle). Shown are the nine study sites distributed in the southern part of the Kulawi valley:

Figure 1.4: Different cacao cultivation systems: 20

Figure 2.1: Map of the study region.

Figure 2.2: Above- and belowground biomass, including standing fine root biomass of the three different cacao cultivation systems.

Figure 2.3: Above- and belowground carbon production of the three different cacao cultivation systems.

Figure 2.4: Litter production of the different cacao agroforests.

Figure 3.1: Standing fine root biomass (a) in the different cacao cultivation systems in the Kulawi valley (Sulawesi, Indonesia) from $0-300 \mathrm{~cm}$ depth, shown in 5 soil depths $(0-20,20-40,40-60,60-100$ and $100-300 \mathrm{~cm})$ and the total profile. Standing fine root necromass (b) in the different cacao cultivation systems from $060 \mathrm{~cm}$ depth, shown in 3 soil depths $(0-20,20-40$, and 40-60 cm) and the total profile. Different capital letters indicate statistically significant differences between the agroforestry systems; lower case letters indicate statistically significant differences in the respective soil depth between the cultivation systems $(\mathrm{p}<0.05)$.

Figure 3.2: Vertical root distribution of fine and large roots of Theobroma cacao, Gliricidia sepium and five other representative shade tree species in the different cacao cultivation systems in the Kulawi valley (Sulawesi, Indonesia); ( $n=$ number of plots).

Figure 3.3: Fine root production in three different soil depths $(0-10 \mathrm{~cm}, 10-30 \mathrm{~cm}$ and $30-60$ $\mathrm{cm}$ ) and the total profile from $0-60 \mathrm{~cm}$ soil depth of the different cacao agroforests in the Kulawi valley (Sulawesi, Indonesia) differentiated in cacao and shade trees. Capital letters indicate statistically significant differences between the agroforestry systems; lower case letters indicate statistically significant differences of the different tree groups between the cultivation systems and lower $(\mathrm{P}<0.05)$.

Figure 3.4: Isotopic composition in $\delta \mathrm{D}(\%)$ of soil water in different soil depths and in tree stem woody tissue of cacao, Gliricidia, and various other shade trees species in a Cacao-Gliricidia and a Cacao-multi plot in the Kulawi valley (Sulawesi, Indonesia). Given are means and standard deviation $(n=4)$. Dashed lines indicate the range of $\delta \mathrm{D}$ values measured in the tree stems. Grey areas indicate the soil depths coinciding with the values found in the plant water in the stems.

Figure 4.1: Relationship between stem basal area increment (BAI) of cacao and four shade tree species and aboveground biomass (AGB)..

Figure 4.2: Hydraulic characteristics. 
Figure 4.3: Cross-sections of different tree parts along the flow path. 120

Figure 4.4: Mean vessel diameter in relation to vessel density in tree organs (roots, stems and branches) along the flow path for the six tree species. 121

Figure 4.5: Relationship between stem basal area increment (BAI) of cacao and four shade tree species and theoretically calculated cross sectional sapwood area-specific hydraulic conductivity $\left(K_{\mathrm{S}}^{\text {theo }}\right)$ in the root (a), stem (b) and branch wood (c). Each symbol represents mean values for each tree species (o Th_ca; $\nabla$ Du_zi; $\diamond$ Gl_se; $\square$ Le_le; •Gn_gn). 


\section{Acknowledgements}

First of all, I want to thank Prof. Christoph Leuschner and Dr. Dietrich Hertel for making this project possible and supervising me through that time. Especially my thanks go to Dietrich Hertel for his advices, help and motivation from the beginning until the very end. I also want to thank the DFG for financing this work as well as RISTEK for all the permissions in Indonesia.

Without the help of many people in Göttingen, Palu, Kulawi and Palolo, I could never have accomplished all the work and have completed this thesis. Therefore, my special thanks in Palu go to Mohammad Fadlan, who was a great assistant; very diligently and always thinking along. Furthermore, he and his wife Ivon became great friends. I also want to thank Edi for his expertise in separating roots, Dewi for scanning all the leaves as well as Ibu Aiyen, Pak Henry and, very important, Anty for all the administrative help in Indonesia.

My field assistants in the Kulawi and the Palolo valley made up a crucial part of this work. I want to thank: Denny, Cade, Hasan, Ahim, Niki, Kaswan, Culing, Pak Rijo, Pak Umar and Sardin, who were my permanent assistants as well as all the other helpers, especially for digging the $3 \mathrm{~m}$ soil pits. It was very hard work, but nevertheless we had a great time working together and also spent a lot of our free time together. I want to thank Rajab from Toro for his great cooking. Furthermore, I want to thank all the inhabitants of the village Watukilo and Gimpu for their hospitality, especially Mama and Papa Arah and above all the family of Cade: Mama and Papa Sarim, Wiwi and her daughter Kaila Umaya, who integrated me in their family as one of them. They gave me a home there and I'm very happy to be a part of their family now.

I also won a lot of new friends in Palu, who I don't want to miss again. Above all I thank Agil, Arul, Ain, Ahl, Debu, Ira, Atok and Ancha for a great time besides the roots, which can really drive one crazy... Everybody working with roots knows what I'm talking about! My very special thanks go to Fabian Brambach, Martyna Kotowska and Andrea Hanf, who I got to know better during our stay in Palu and became very important friends. Fabian created all the maps used in this thesis and helped me identifying the shade tree species on my study plots for what I'm very thankful. Furthermore, he helped me a lot with his advices and friendship in good as in very difficult phases in my life as well as Martyna, who also helped me a lot in scientific questions. Andrea provided important data for the carbon stocks and for the Deuterium analyses used in this thesis.

In Göttingen, I want to thank especially Irmgard Gerstman. Without her help I would never have been able to process all the samples in time. Furthermore, I want to thank all my colleagues from the department, especially Petra Kubisch, Natalia Sierra Cornejo, Stefan Kaufmann, Daisy Cárate, Stefan Meyer and the best office mate ever, Torben Lübbe. Besides them I want to thank Sarah Burns, Hilario Espinosa and Federico Dradi. They all became very important and close friends and supported me a lot, when I needed it, but we also spent a lot 
of happy and funny hours together. And of course I want to thank Michael Egan, who became more and more important for me during the last months of this thesis.

My very special thanks go to Franziska Bucher, who supported me a lot personally and scientifically and read the corrections, as well as Luisa Zeidler, Madeleine Wowarra, Marina Boose, Dennis Wiese and Rosalia Lipscomb, who are very important friends for so many years already. Without their mental support I wouldn't be, where I am now. I also want to thank Renzo De La Peña, who accompanied me many years of my life and help me a lot in many aspects. And of course I thank my family for always supporting me and being there, when I need them in no matter what. Above all, I thank my brother Jakob Abou Rajab and his wife Jennifer Fehr for always being there for me and for making me a very proud aunt and my aunt Ulrike Klett, who is like a very close friend for me and always gives very helpful advice. I also owe great thanks to my mother Constanze Klett and my grandparents Ruth and Constantin Klett, who always supported me and made me the person I am, although it was not always easy.

This poem is dedicated to all, who are still struggling (in any respect):

\section{Don't Quit}

by Anonymous

When things go wrong, as they sometimes will, When the road you're trudging seems all uphill, When the funds are low and the debts are high, And you want to smile, but you have to sigh,

When care is pressing you down a bit

Rest if you must, but don't you quit.

Life is queer with its twists and its turns, As everyone of us sometimes learns, And many a failure turns about

When they might have won, had they stuck it out.

Don't give up though the pace seems slow,

You may succeed with another blow.

Often the goal is nearer than,

It seems to a faint and faltering man,

Often the struggler has given up

When he might have captured the victor's cup;

And he learned too late when the night came down,

How close he was to the golden crown.

\section{Success is failure turned inside out}

The silver tint of the clouds of doubt

And you never can tell how close you are,

It may be near when it seems so far;

So stick to the fight when you're hardest hit,

It's when things seem worst that you must not quit! 


\section{Declaration of originality and certificate of ownership}

I, Yasmin Joana Monna Abou Rajab, hereby declare that I am the sole author of this dissertation entitled 'SHADE TREES IN CACAO AGROFORESTRY SYSTEMS: INFLUENCE ON ROOTS AND NET PRIMARY PRODUCTION'. All references and data sources that were used in the dissertation have been appropriately acknowledged. Furthermore, I declare that this work has not been submitted elsewhere in any form as part of another dissertation procedure.

Göttingen, September 16th, 2016

(Yasmin J. M. Abou Rajab) 